$1-1-1899$

\title{
Report on investigations to determine the cause of unhealthy conditions of the spruce and pine from 1880-1893
}

\author{
A. D. Hopkins
}

Follow this and additional works at: https://researchrepository.wvu.edu/ wv_agricultural_and_forestry_experiment_station_bulletins

\section{Digital Commons Citation}

Hopkins, A. D., "Report on investigations to determine the cause of unhealthy conditions of the spruce and pine from 1880-1893" (1899). West Virginia Agricultural and Forestry Experiment Station Bulletins. 56.

https://researchrepository.wvu.edu/wv_agricultural_and_forestry_experiment_station_bulletins/56 @ WVU. It has been accepted for inclusion in West Virginia Agricultural and Forestry Experiment Station Bulletins by an authorized administrator of The Research Repository @ WVU. For more information, please contact ian.harmon@mail.wvu.edu. 

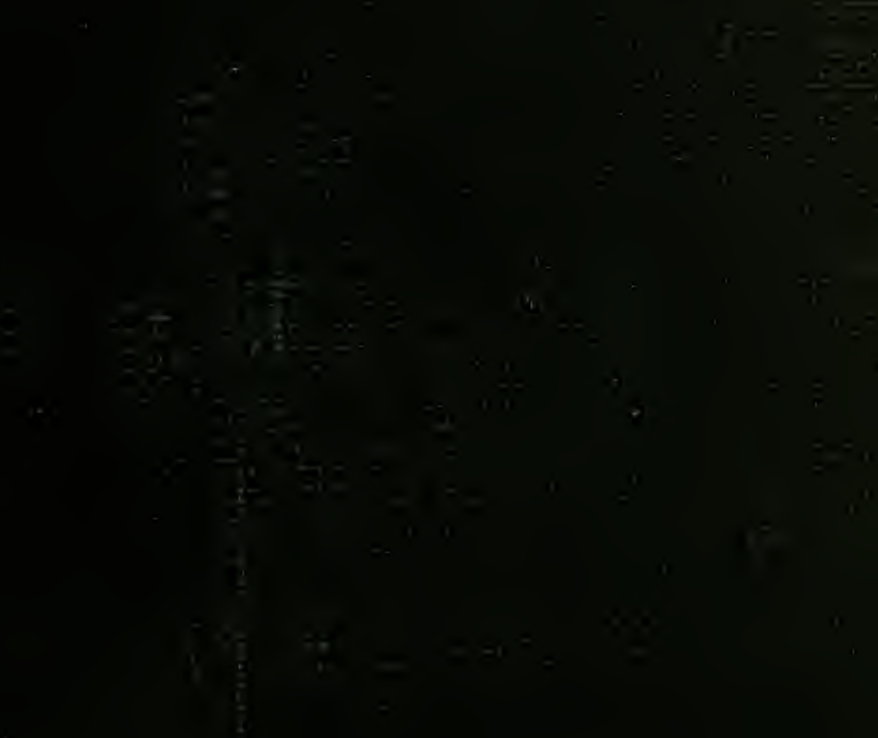
Digitized by the Internet Archive in 2010 with funding from

Lyrasis Members and Sloan Foundation 


\section{WEST VIRGINIA}

\section{AGRICULTURAL EXPERIMENT STATION,}

MORGANTOWN, W. VA.

REPORT ON INVESTIGATIONS TO DETERMINE THE CAUSE OF UNHEALTHY CONDITIONS OF THE SPRUCE AND PINE FROM 1880-1893.

By A. D. HOPKINS.

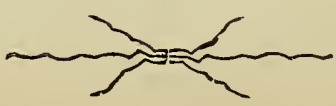




\section{THE REGENTS OF THE WEST VIRGINIAEUNIVERSITY.}

NAME OF REGENTS.

Hon. GEORge C. Sturgiss

HoN. J AMES F. BRown

Hon. A. H. Kunst

Hon. Richard Randolph McMahon

HoN. J AMES M. LEE

Hon. James L. Hamill

Hon. John A. CampbelL

Hon. W. E. Powell

Hon. P. O. Easturan
P. O. ADDRESS.

Morgantown

Charleston

Weston

Harper's Ferry

Lewisburg

Welch

New Oumberland

Yarkersburg Pt. Pleasant

\section{STATION COMMITTEE.}

George C. Sturgiss.

JaMES L. HaMiLL.

JAMES F. BRown.

President Regents

President University

'Treasurer

Auditor

\begin{abstract}
Geo. C. Sturgiss. Jerome H. Raymond, A. M., Рн. D. A. R. Whitehill, Ph. D.
\end{abstract} S. G. Chadwick.

STATION STAFF.

JaMes H. Stewart, A. M.,

A. D. Hopkins, Рн. D.

Bert H. Hute, M. S.

L. C. Cokbett, M.S.

W. E. Rumsey, B. S. Agr.

T. F. Watson, B. S.

Horace Atwood, M: S.

C. D. Howard, B. S.

E. C. Frame,

M. A. Stewart,
Director and Agriculturist Vice Director and Entomologist

Chemist Horticulturist Assistant Entomologist Assistant Chemist Assistant Agriculturist Assistant Chemist Clerk and Stenographer Librarian 


\section{CONTENTS.}

\section{PART I. \\ 'IHE SPRUCE INVESTIGATION.}

Page.

INTRODUCTORY,

Acknonoledgements, 198. List of published titles by the author, referring to work and results of the spruce and pine investigation, 200

The Spree Investigation,

The Spruce in West Virginia, 203. Common and technical names, 203. Description, 20\%. Distribution, 208. Some of the early disturbing influences, 211. Mountain pastures, 213. The original area greatly reduced. 215. Present conditions in the spruce area, 216. Probable future of the spruce area as indicated by present conditions, 221. Commercial influences in their relation to the future of the spruce area, 223. Agricultural influences, 225. The importance of perpetuating the forest resources of the area as a source of wealth to its inhabitants and the State, 226. The relation of entomological research to the preservation and perpetuation of forests, 229.

Report on Investigations to determine the Cause of the UNhealtiy Condition of the Spkuce between 1880 and 189 ;,

Disturbing infuences, 230. History and progress of dying spruce timber in the spruce area, 232. Cause of the first trouble, 235. Cause of the second trouble, 23\% A circular letter to lumber companies, 238. Distributing the European bark-beetle destroyer, 239. End of the trouble, 239. Rapid decay of dead spruce timber in one section of the spruce area, 239. Wood-peckers the principal enemy of the destructive sapwood borer, 242 . Present condition as to insect enemies, 242.

The Principle Insect Enemies of the Spruce in West Vinginia,

Bark Miners, 244. The destructive pine bark beetle, 245. The destructive spruce bark beetle, 246. Le Conte's spruce bark beetle, 251. The cosmopolitan spruce bark beetle, 252. Eichhoff's five-toothed pine bark beetle, 253. Say's pine bark beetle, 253. Flat headed spruce bark miners, 254. Round headed spruce bark miners, 255.

Wood Miners, 255. Timber or ambrosia beetles, 256. The spruce timber beetle, 256. Round headed wood miners, 258. The destructive spruce wood miner, 259 . Injury to terminal branches by the white pine weevil, 259. Injury to twigs by the spruce gall louse, 260.

Principal Insect Friends of the Spruce, or enemies of the iNSEC'T ENEMIES,

Predaceous beetles and their larvae, 262. The Clerids, 262. American bark beetle destroyer, 262. Staphylinids or rove-beetles and their larvae, 264. Histerid beetles, 265. Nitulid beetles, 265. Tenebrionid beetles, 266 .

Parasitic Enemies,

Ichneumonid parasites, 266. Braconid parasites, 266. Chalcid parasites, 267. Trachinid parasites, 268.

Diseases of Insect enemes of The Spruce, . . . . $\quad 268$

BIRDS AS FRIENDS OF THE SPRUCE, ․ . . . . . . . $\quad$. 269

Other Benefictal Elements . . . . . . 269 
PART II.

\section{THE PINE INVESTIGATION.}

The Pine of West Virginia,

The white pine, 2\%1. The yellow pine, 271. The pitch or black pine, 272 . The scrub or Virginia pine, 273 . The table-mountain pine, 273. The loblolly pine, 274. The red pine, 274 .

Commercial products of pine,

Past and present conditions of pine in West Virginza, 276. Original distribution, 276 . Present distribution and conditions, 27\%. Influences which have caused the destruction of the pine timber of the State, 2\%8. The relation of the pine in amount and value to other kinds of forest trees, 280. Rate of consumption to that of natural increase, 281 . Comparative value of second growth pine to that of other kinds of timber trees, 281.

The principal encmies of the pine,

History of the Investigation to Determine the Cause of the

Unhealthy CONDition of the TIMber,

First Observations, 283. Correspondence, 284.

Special Investigatioxs Comienced,

Character of trouble described, 28\%. Investigations to a etermine the cause of the trouble, 288. Trees dying from a disease, 288. Trees dying probably from natural causes, 288 . A peculiar character of the common trouble, 289. The cause of the common trouble discovered, 289 .

The Dying Pine Forests, (Quotation from article), 291. Further investigations, 292. Extract of article from Science, 293.

The Consideration of Remedies,

The Inportation of Tatural Enemies of Burk-beetles Considered,

The Pine and Spruce Threatened with Total Destruction,

Special Correspondence to Ooners of Spruce and White Pine Tim-

ber in West Virginia,

Correspondence with Entomologists in Germang; . . . . 300

Letter from Oberforster Eichhoff, . . . . 300

Letter to Timber Correspondents. . . . . . 301

Amounts Contributed by Owners of Timber, . . $\quad 302$

Letter of Instructions from the Director (John A. Myers,) . 302

Accoun't of Mission to Europe,

Investigations near Hagenau, 304. The desired beneficial insect found, 304. Return to Strassburg, 305. Investigations in Saxony, 306. Returned to Strassburg, through Bavaria and Baden-Baden, 307. Investigations continued near Hagenau, 308. Investigations in the Vosges mountains, 309. Great destruction of timber by snow and wind, 309 . Observations on the habits of Clerus form1carius, 311 . Further work prevented by a cholera epidemic, 313. Letter from Director Myers, 314. Ten days in Switzerland, 315.

RETURN TO AMERICA,

Stop at Washington, D. C. and Attend a Meeting of the Entomological Society, 31\%. Remarks at meeting of Entomological Society at Washington, (from Insect Life), 318.

ON the Introduction of the European Bark-Beetle Destroyer, Clerus Formicarius to america, (Extract from article in Science by Camillo Schaufuss, translated from the German.) 
First IMPORTed Clerids Liberated in AmErica.

Letter to Timber Companies,

The Imported Specimens Stored for the Winter,

An Effort to Secure Legislation With Reference to the ConTROL OF Forest Insects, .

323

Importance of having more entomological work done in the State, and the desirability of the Legislature making provisions for it, 323. No action taken by the Legislature, 325. Letter to timber companies, 325 .

IMPORTED IxSECTS DISTRIB UTED IN 1893,

Methods of Locating Colonies of Imported Insects,

The Carrying Out of the Primary Objects of the Importation oe the Clerid into america Prevented by the Disappearance of the Destective Pine Bark Beetle, 328. Number of ExAMPles of THe Clen id Collected, Imported and Destributed Between A CGest 29. 1892, AND MaY 30, 1894,

Tables showing distribution and amounts subscribed, 330 . Statement of expenditures, 330 .

Further Observations With Reference to Dying Pine, and the Destructive Bark Beetles, During the Stmier and Fall of 1892 ,

Alarming Character of the Trouble, no Further Doubt Regarding the cause, 335. Further observations on natural enemies, 336. Dying: pine and spruce in Maryland and District of Columbia, 336 . Observations after returning from Europe, 337. No abatement of the trouble at the close of $1892,338$.

Observations During the SPrixg, Summer axd Fall of 1893,

Conditions in Monongalia county in scrub, pitch and yeliow pine, 339. Condition in Raleigh county, in white pine, 340 . All the examples of the destructive pine bark beetles dead, 341 . Other bark beetles threatening the timber, 342. Conditions in Kanawha county scrub pine, 343 . Conditions in Greenbrier county scrub pine, 344. Conditions in Greenbrier and Pocahontas counties, white pine, 345 . Conditions on William's river spruce, 346. Swarms of bark beetles, 346 . Conditions in Tucker county, pitch pine, 348. White pine, 348. Conditions in Randolph county, spruce, 348. Conditions in Grant county, spruce, 349. Norway spruce, Morgantown, 350. Conclusions from observations in spring of 1893, 350. Conditions reported to owners of timber, 351. Further notes in 1893. Webster, Púcahontas and Greenbrier counties, 352. Extracts from paper read at Madison, Wisconsin, 353. Observations in Tibbs Run forest, 355. In Raleigh county, white pine, 356. In the Mayfield Hill Grove, $35 \%$.

Conditions in 1894, .

Conditions in the Spruce, 358. Conditions in the Mayfield Hill Grove, 358. Conditions in southern, south-western part of the State, 359. Serious trouble over, Extract from articles in timber journals, and newspapers, 363.

OBservations in 1895 aNd 1896.

No living examples of destructive species found, 366 . Other bark beetles not exterminated, 366 . Swarms of bark beetles, 366: A 
new trouble threatened by the swarms, 366, Trees attacked by other bark beetles did not die, $36 \%$. The trouble ended, $36 \%$.

Conclusions,

Cause of the trouble, $36 \%$. Then the destructive bark beetle disappeared the timber quit dying, 36\%. Further trouble prevented, 368 .

A rea Invaded by the Destructive Pine Bark Beetie،

Two Rejarkable Features of the Ixvasion, , 369

On the Causes of the Uxiversal Death CF the Insect,

Climatic Conditions, 3\%0. Table of Temperatures Dec., 1892, and Jan., 1893, 371. Insect Diseases, 374. Parasitic and Predaceous Enemies, 378. Conclusions, 378.

Some of the Principal Insects As sociated with the Pine TROUBLE,

The Scolytids, 379. Some general features and habits, 379. General habits, 379. Their preference for coniferous trees, 379. Grouped according to habits, 380 . The mines or galleries, 381 . Distribution of species, 385. Natural enemies, 386. Predaceous enemies, 386, Parasitic insėct enemies, 386. Parasitic diseases, 387 Birds, 387 Unfavorable climatic and other conditions, $38 \%$.

F'RIEXDS OF SCOLYTIDS, $38 \%$

Insect friends, 388. Forest fires, 388. Climatic and other natural conditions favorable to the existance of Scolytids, 389.

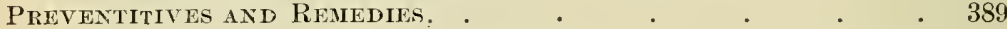

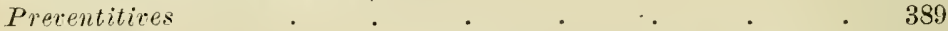

Remedies . . . . . . . . . 390

A Knowledge of the Insccts and their Habits Hay Prevent Serious

losses from their Ravages, . . . . . . 391

Destructive Bark-BeEtles, . . . . . . . 392

The yenus Dendroctonus, 392. D. terebrans, 392. D. rufipennis,

..93. D. simplex, 394 . D. frontalis, 394 .

The Uestructive Pine Bark Beetle,

Descriptions, 394. The egg, 396. Larva, 396. Pupa, 396. Galleries, 39\%. Life history, 401. Stages of development, 401. Number of broods, 401. Habits, 403. Habits of flight, 406. Distribution, 40\%. Host plants, 40\%. Natural enemies, 408. Parasitic eremies, 468. Predaceous énemies, 409. Robbers, 410. Birds, 410. Diseases, climatic conảitions, etc. 411. Friendly elements, 411. Remedies, and preventitives, 412. Future outbreaks liable to occur, 412.

Characteristic features of injury to forest and shade trees by Den. droctonus frontalis,

The Turpentine Bari-Beetle,

Description of adult, egg, larva and pupa, 415. Habits and life

history, 416. Character of injury, 419. Kind of trees attacked, 120. Natural enemies, 420 .

Genus Tomicus,

T. Calligraphus, 422. T. cacographus, 422. T.pini, 422. T. avulus, 422. T. caelatus, 423 .

\section{APPENDIX.}

OF INSECTS COLleCted by the AUthor From SPRUCE AND Pine in West Virginia, 
REPORT ON INVESTIGATIONS TO DETERMINE THE CAUSE OF UNHEALTHY CONDITIONS OF THE SPRUCE AND PINE FROM 1880-1893.

\author{
By A. D. Hopkins.
}

INTRODUCTORT.

This report is on the work and results of special investigations conducted by the author in the spruce and pine forests of West Virginia, to determine the causes of the unhealthy conditions of the timber, which prevailed between 1880 and 1893 , resulting in the death and total loss of many hundred thousand dollars worth of the finest timber in the State.

The spruce investigation was begun in Septembor, 1890, when in company with Dr. C. F. Millspangh, (then Botonist of the Station) we found great quantities of dead spruce near Cheat Bridge, in Randolph county. The evidence obtained at the time indicated that the crouble was cansed by insects. Hence, a general study of the conditions prevailing in the spruce forests of the State, and a special study of the destructive, injurious and beneficial insects associated with the living and dead spruce was taken up as a special feature of the work of the Entomological Department of the Experiment Station, which received a large share of my attention from time to time until 1894.

The pine investigation was commenced in 1891 , when I found some timber dying in Hampshire county, in July of that year. Enormous quantities of pine and spruce died during 1891 and 1892 , and every facility necessary to prosecute a detailed study of this trouble was offered, both by the Director of the Experiment Station and the owners of large bodies of sprace and pine timber, the latter contributing nearly all of the expense of a 
trip to Europe to study the natural enemies of destructive pine and spruce insects.

While the report is prepared mainly for the general reader, and especially those interested in the spruce and pine resources of the State, yet it contains some matter of a more or less technical nature, intended for persons interested in natural history or systematic and economic entomology.

\section{ACKNOWLEDGMENTS.}

I wish to acknowledge in this connection my obligations and appreciation of the interest and encouragement extended during the period 1890-1893 by members of the Board of Regents of the University, and Station Committees, and the Director of the Station, Dr, John A. Myers, to whom I am under special obligations for the opportunity and facilities so liberally offered for undertaking and successfully prosecuting the investigations; also to my early associate in Station work, Dr. C. F. Millspangh, for advice and kind recommendations when the work was commenced.

It seems proper that I should make special mention in this connection of persons in Europe to whom I am under obligations for the kindness, and valuable aid, so heartily extencled to me during the investigations in Europe and in carrying on the experiments here. Of those who deserve special mention for favors and assistances extended during my investigations in Europe I would mention first the late Oberforester W. Eich hoff, of Strassburg, Gelmany, who was especially kind in providing the necessary papers which gave me free access to the forests of Alsace and Loraine, as well as introductions to the principal forest officials; also for valuable information and kind hospitality, and many other favors which I remember with much pleasure; to Director Camillo Schaufuss of the museum at Meissen, Saxony, I am also under obligations for many personal favors and valuable assistance in the collection of insects, as 1 am also to Oberforester Strahmeyer, his son, H. Strahmeyer and Mr. E. Baldauf, of Hagenan, Alsace, who were exceedingly kind in offering every facility for the successful pro- 
secution of the work in the Hagenau forests, and especially $\mathrm{Mr}$. H. Strahmeyer, who collected such a large number of specimens with the funds entrusted to him. I should not fail to mention also Oberforester Pittz, of Abreschwiller,Loraine, who accompanied me into the spruce forest in his charge, and was so liberal in his efforts to further the objects of my mission there.

In this country I have to mention the several public spirited companies and individuals who made it possible with their liberal contributions, to personally conduct the investigations in Europe and select the most desirable species for importation. This movement on the part of these owners of only a small portion of the threatened timber was not, as I have reasons to know, through a desire to advance personal interests so much as it was to contribute to the general welfare of the limber interests of the State and country and to give encouragenent to scientific research. The individuals of the companies who were especially interested in this matter were: Hon. J. N. Camden, President of the West Virginia and Pittsburg Railroad Company, Mr. E. L. Tunis, General Manager Condon Lane Boom and Lumber Company; Robert H. Henderson, President of the Cumberland Lumber Co; E. C. Burt, President of the St. Lawrence Boom and Lumber Company; E. A. Monaghan, Lock Haven, Pa., and J. R. Beatty \& Company, Urow, W. Va.

I should also mention the liberality of Dr. C. V. Riley, Dr. L. O. Howard, Mr. Wm. A. Ashmead, Mr. E. A. Schwarz and others of the U. S. Department of Agriculture and the National Musuem. In the illentifications of specimens and the use of material for study; also my assistant, Mr. Rumsey, for some of the excellent photograph reproduced in the report and other efficient assistance in office and laboratory work; and finally the present Director of the Experiment Station, Hon, J. H. Stewart, for liberal allowance, from the stationary and printing fund, for illustrations and publication.

'The greater part of the MS. for this report was prepared in 
1894-95, but owing to the lack of funds available for the purpose, the publication of the same has been delayed. In the meantime references have been made to the investigations and to part of the results in bulletins, annual reports and papers read at scientific societies and articles in scientific and other journals, newspapers, etc. These references may be found under the following bibliography. The pages refer, as a rule, to the entire article, and not to the references which are scattered through some of them.

Apr., 1899.

A. D. Hopkins.

All of the Illustrations in this report are original, except as noted under figure.

\section{BIBLIOGRAPHY.}

List of pubtished titles by the author under which reference is made to some of the work and results of the spruce and pine incestigations.

Preliminary Report-Black Spruce, (Investigation.) Bull. 17,

W. Va. Agr. Exp. Station, May 1891. pp. 93-102. Also

Third Án. Rep. W. Va. Agr. Exp. Station, 1891. pp. 171180.

Notes on Destructive Forest Tree Scolytids, Science, Vol. 20, July 29, 1892, p. 64.

The Pine Beetle of the Virginias, Hardwood, Vol. 2, November 25 th, 1892 , p. 7 .

First Announcement of the Importation of the European Barkbeetle Destroyer into America, Proc. Ent. Soc. Wash., Vol. 2,1892 , p. 353 .

Damage to Forests by the Destructive P'ine Bark-beetle. (Insect Life, Vol. 5, January 1893, pp. 187-189.

Catalogue of West Virginia Scolytidae and Their Enemies, (Bull. No. 31, W. Va. Agr. Exp. Sta., April 1893, pp. 121168 ;) includes list of spruce and pine scolylids and their enemies, with collecting and breeding dates.

Catalogue of West Virginia Forest and Shade Tree Insects, (Bull. No. 32, W. Va. Agr. Exp. Sta, May 1893, pp. 171-251.) Including list of spruce and pine insects, with collecting and breeding dates. 
Notes on List of Pine Infesting Insects. (Proc. Ent. Soc. Wash. 1893, V. 3, pp. 192-193.

Destructive Scolytids and Their Imported Enemy. (Insect Life, V. 6, December, 1893, pp. 123-129. Also in 24th Ann. Rep. Ent. Soc. Ont., p. 71.)

The Relations of Insects and Birds to Present Forest Conditions. (Garden and Forest, 1894, p. 348.)

Notes on Some Discoveries and Observations of the Year in West Virginia. (Insect Life, Vol. 7, October, 1894, pp. 145 151.) A Serious Trouble Over. Southern Lumberman, 1894. Timberman, 1894. (Hardwool, Vol. 6, November, 1894, pp. 270 . 271.)

On the Study of Forest Tree Insects. (Proc. Assoc. Evon. Ent. Bull. No. 2, N. S. Div. Ent. U. S. Dep. Agr., 1895, pp. 75 -79. 26th Ann. Rep. Ent. Soc. Ont., 1895, pp. S0-83.)

Some Notes on Insect Enemies of Trees. (Can. Entom., October 1596, pp. 243-250.

Reports of the Director. (4th Ann. Rep. W. Va. Agr. Exp. Sta., 1891. pp. 59-64. 5th Ann. Rep., 1892, pp. 40.46. 6th Ann. Rep., 1593, pp. 29.48. Tth Ann. Rep, 1894, pp. 34-44. Sth Ann. Rep., 1895, pp. 27-35. 9th Ann. Rep., 1596, pp. 6.5-164. All published in 1897. 10th Ann. Rep., 189T, pp. 42-57. 11th Ann. Rep., 1898, pp. 33-34. The Director, Dr. Jno. A. Myers, also refers to the investigations in the 5 th Ann. Rep., p. S. 6th Ann. Rep., pp, 7-S. 7th Ann. Rep.: pp. 9-10. Sth Ann. Rep. pp. 5-6. 

PART I.

\section{THE SPRUCE INVESTIGATION.}

'TIIE SPRUCE IN WEST VIRGINIA.

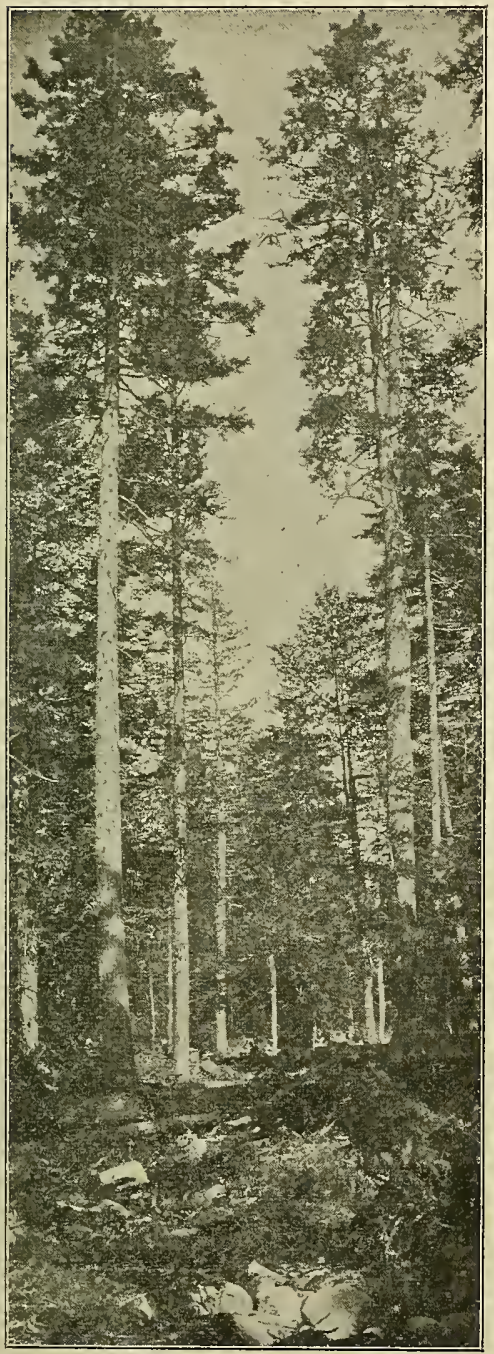

Fig. I.-A typical specimen of the Black Spruce on left of picture, and soil in which it grows.
Before entering into a detailed discussion of the results of investigations to determine the cause of troubles, which from time to time resulted in the death of great quantities of spruce timber, it seems desirable to give a review of some results of observations regarding the spruce, the areas oc. cupied by it in the State, and the conditions which have from time to time contributed to its destruction.

COMMON AND" TECINICAL NAMES.

As is unfortunately the case with many of our common species of plants and animals, there has been much confusion, due to the many common and scientifis names applied to the spruce of the Ailegheny Mountains. It is known in different localities as pine, yew pine, spruce, spruce pine, hemlock, black spruce and red spruce.

It has also been described under a number of technical 


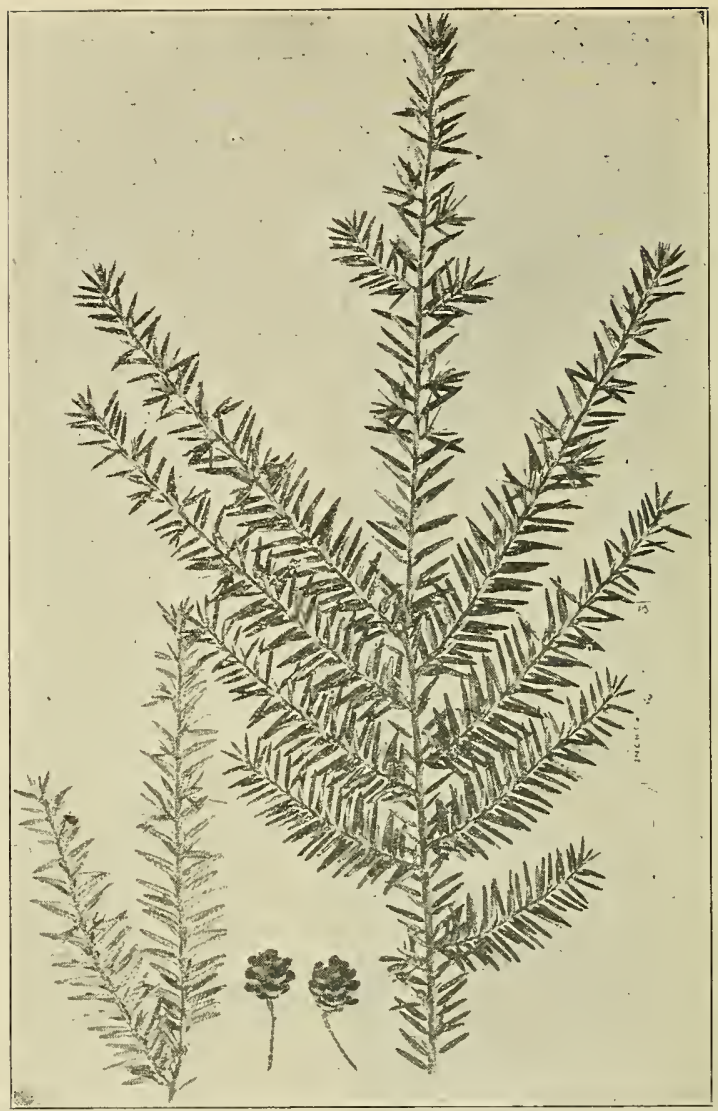

Fig. 11.-Hemlock branches and cones, about one half natural size.

names, and there is yet some confusion regarding the correct name of the two nearly allied species, which are believed to occur in West Virginia. The common and large species is thought by some botanists to be the red spruce, Picea rubens Sarg., while it is claimed by others to be the true black spruce, Picea mariana. (Mill) B. S. P.

This confusion in common and scientific names is particularly unfortunate as applied to this timber tree which was becoming 
generally recognized as black spruce by manufacturers, dealers and consumers of its valuable products. Probably the simplest and easiest way to remedy the confusion arising from change of names, of a common timber tree, is in this case simply to adopt the name of spruce, which will answer for com-

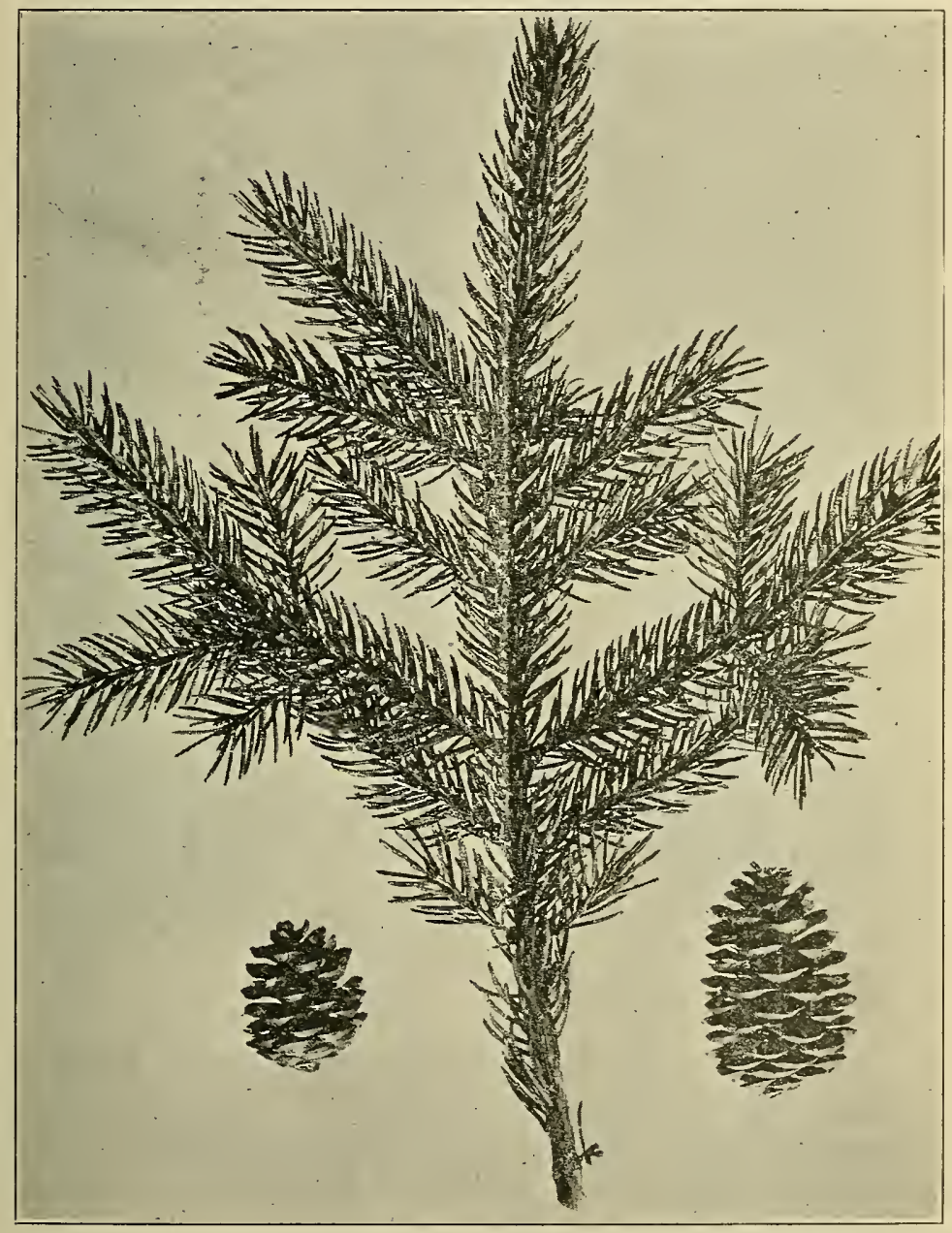

Fig. III.-Black Spruce branch and cones, about one half natural size. 


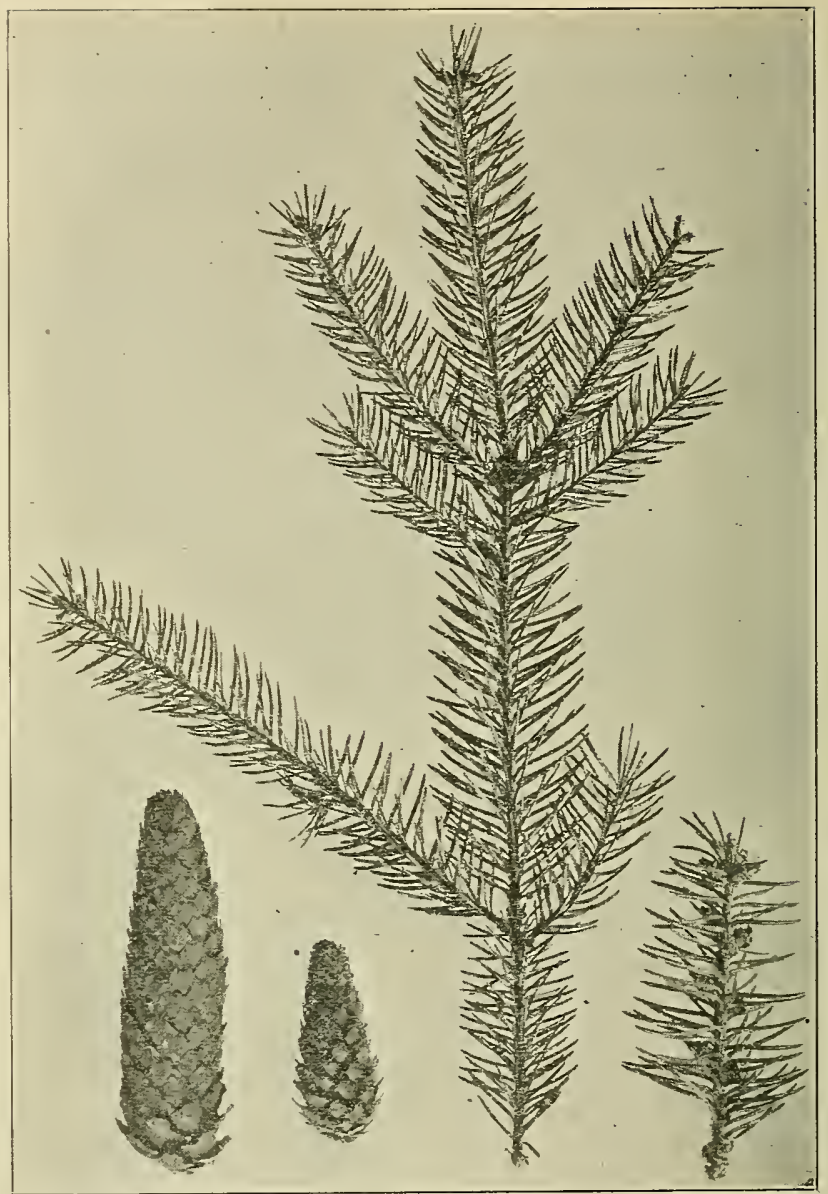

Fig. IV.-Norway Spruce, (Abies excelsia.) branches and cones: About one half natural size.

mercial purposes quite as well as the name black or red spruce, to indicate the only two timber spruce we have in the State, the products of which are nearly or quite alike in every respect.

It must be remembered that the spruce is quite a different tree from the hemlock, (Fig. II,) which in sections where the true spruce does not grow is sometimes called spruce. 


\section{DESCRIPTION.}

The spruce (Fig. I) is easily distinguished from all of our timber trees by the following characteristics: It is a tall, straight tree, attaining a maximum diameter of two to three feet at the base, and a height of over one hundred feet. The cones (Fig. III) are one, to one and three-fourth inches long, occurring singly or in clusters, most abundant at the top of the tree. The leaves are short and stiff, dark green and thickly set ou the young branches, the larger branches usually extend at right angles, to the main trunk and droop towards the tips, forming a conical top, resembling closely in this respect the introduced and cultivated Norway spruce, (Fig. IV). The wood is light and strong, although frequently filled with small knots. It is used principally for frame stuff, siding, inside finish and singles, and is also largely used for the manufacture of high grade paper pulp. Whenever the conditions are favorable for the growth of this tree, it forms dense and nearly pure forests of fine timber, yielding from ten to fifty thousand feet, board measure, of lumber to the acre. It seems to thrive best on rocky slopes and ridges, and flat and swampy mountain plateaus. In rich, deep, limestone and clayey or sandy soils even at high elevations, the conditions are unfavorable for it to form dense forests, ( $\mathrm{Fig}$. V), since it is less capable of surviving in the struggle for existence with birch, maple, beech and other hard-wood trees, which usually occupy such lands. It is therefore pre-eminently fitted to ocenpy land which is worthless for almost any other purposes. It is seldom found growing naturally in West Virginia below an elevation of 2,300 feet above the sea, and is most abundant at and above 3,000 feet. Indeed, the various species of spruce and fir, indigenons to the eastern part of North America, occur only at high elevations and in northern latitudes. becoming more abundant and forming great forests towards the sub-arlic regions where according to Sargent they extend in a great belt across the continent. Therefore, they are distinctly northern in their general distribution, and can thrive naturally only in a cold climate like that prevailing in Central and North Canada, hence, it can only grow naturally in West Virginia at high altitudes 


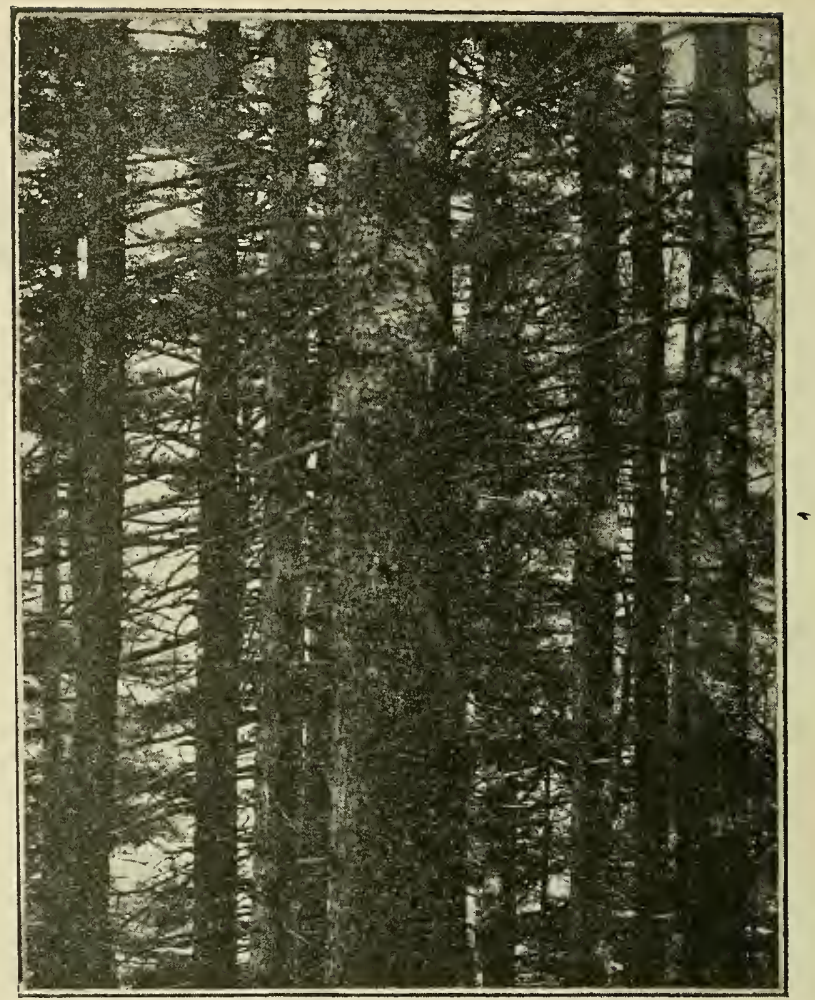

Fig. V.-Glimpse in a Dense Spruce Forest.

where the climate is equal or similar to that of Canada. Indeed, its presence in mixed or pure forests in the State is an infallable index that a Canadian climate prevails, and that the area occupied by it is in the so-called Canadian Life Zone, where other life, both plant and animal, common to a northern latitude may be found.

\section{DISTRIBUTION.}

It is evident that many thousands of years ago, when the great ice sheet covered the greater part of North America and extended nearly to the Northern border of the West Virginia area, the spruce was widely distributed over the hills and mountains of the State wherever the soil conditions were favorable for its growth, but after the ice receded and the climate 
moderaled, it became restricted in its distribution to the higher elevations of the mountains, where in the great struggle for existance, it maintained its supremacy over large areas. When the area began to be settled by white people, a disturbing influence was introduced, which resulted in the destruction of vast quantities of the timber, and as a prevalent forest tree its range has been continually reduced until at present we find only a remnant of the primitive forests which once prevailed.

The spruce reaches its highest development and forms almost pure forests in Grant, Tucker, Webster, Greenbrier, Randolph and Pocahontas counties, where the Cheat, Valley, Greenbrier, Elk and Gauley rivers find their sources in the

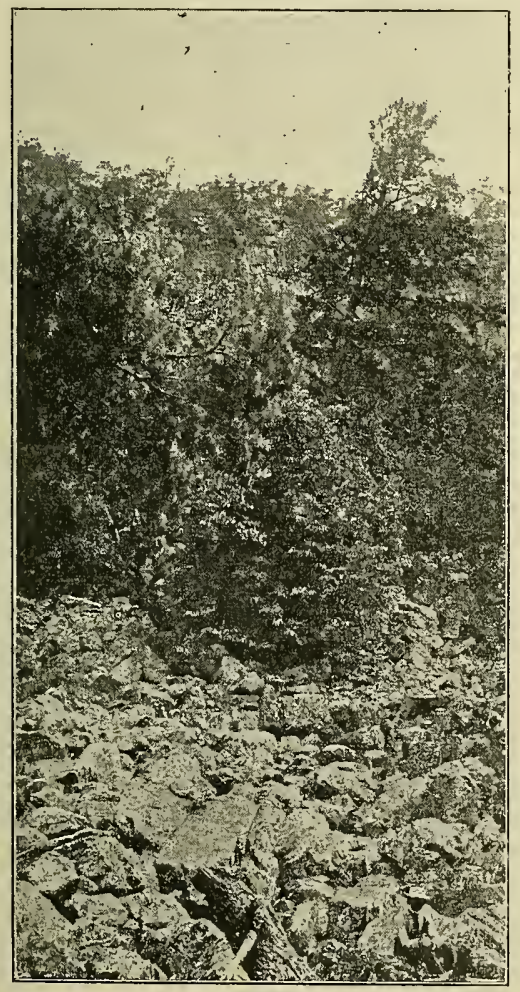

Fig. VI.-A rocky surface like that in which Spruce Timber grows. numerous small everflowing headwater streams. This remarkable area of river sources is suggestive of what is really found, namely: that the most favorable characteristic con. d it i o n s for the prolific grow th of the spruce, aside from a high elevation and consequent Canadian cli. mate, is the superabundant moisture in the soil and air. The soil in many typical spruce forests is ittrle else than a mass of broken stones, which is literally filled with water at almost all seasons of the year, thus rendering it possible for a heavy growth of large spruce trees to develop where there is apparently but little earth in reach of 
their widely spreading roots. (Fig. VI). In fact I have observed many such places where, after the trees had been removed and the surface burned over, there was apparently not enough soil in a square rod to meet the ordinary requirments of a hill of corn.

Through the southern portion of Hampshire county, the central and eastern and western portion of Hardy, the central and eastern portion of Pendleton, through the eastern portion of Pocahontas, Greenbrier and Monroe, and in Summers, Fayette, Raleigh, Mercer, Wyoming and McDowell counties, we find areas of greater or less extent ranging in elevations from 2,400 to 4,000 feet above tide water, where it would appear that the spruce should be found in abundance, yet while it occasionally occurs here in typical forest growth over a few arres, it is, as a rule, when found at all, in this its eastern and southern limit, in the State, simply as a few scrubby individuals among the luxuriant growth of hardwood and white pine. The contrasting drier and warmer conditions of the air and soil through forest and open country of this region is, therefore, as compared with the spruce region proper, unfavorable for the growth of this tree in pure forests. It would appear, however, that when all of this Allegheny region of high altitudes was coverned with an unbroken forest, as it doubtless was just prior to its settlement by the first white people, the more abundant moisture in the soil and atmosphere attending this forest covered condition, made it possible for the spruce to occupy, as the principal grow th all of these higher elevations which at present are covered with other kinds of timber. The area or belt in which the spruce was then found, probably covered all of the higher elevations of the Appalachian range that rise above 2,400 feet, which would be an area of about 2,000,000 acres, on which one-half of the timber was probably spruce. If so, there was about 1,500 ,000 acres of spruce forests here when the first white settler occupied the territory. Since that time there has been a gradual reduction from various disturbing influences. (Fig. VII.) 


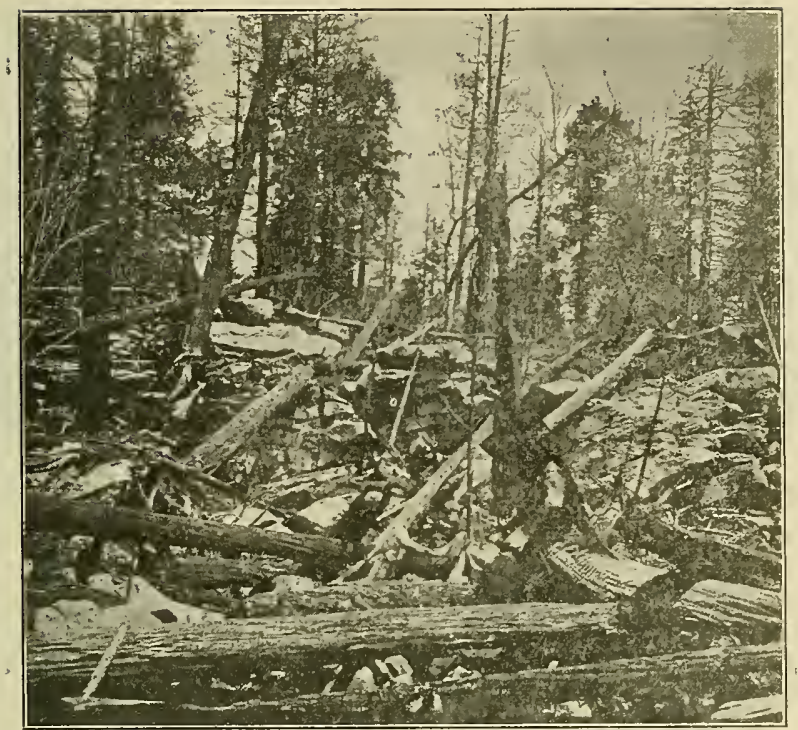

Fig. VII.-Spruce Forest, showing destruction by fire, and the rocky condition of the surface on which the trees grow.

\section{SOME OF THE EARLY DISTURBING INFLUENCES.}

In a resume of the several influences which have tended to lessen this forest area to its present comparatively small proportion, we find that in addition to the destruction of the forests by man, insects have taken a prominent part. The changed conditions brought about by the early clearings of the fertile valleys of the Greenbrier, Potomac, James and Valley Rivers, and the rich country in the southern end of the region, probably had the effect of materially reducing the humidity of the atmosphere and soil, and of exposing the more narrow and isolated mountain ranges of the eastern portion to drying winds, forest fires (Fig. VIII) and fierce storms. This naturally had the effect of weakening the vitality of the spruce, and together with extensive wind falls, of which we have some early records, the most favorable conaitions were offered for the increase and destructive invasions of spruce in- 


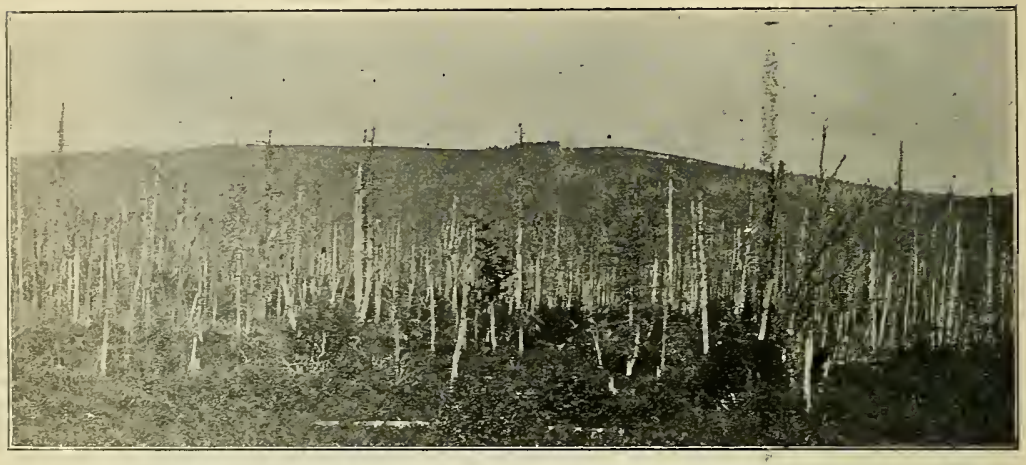

Fig. VIII.-Dead Spruce Timber in the Cannan Valley.

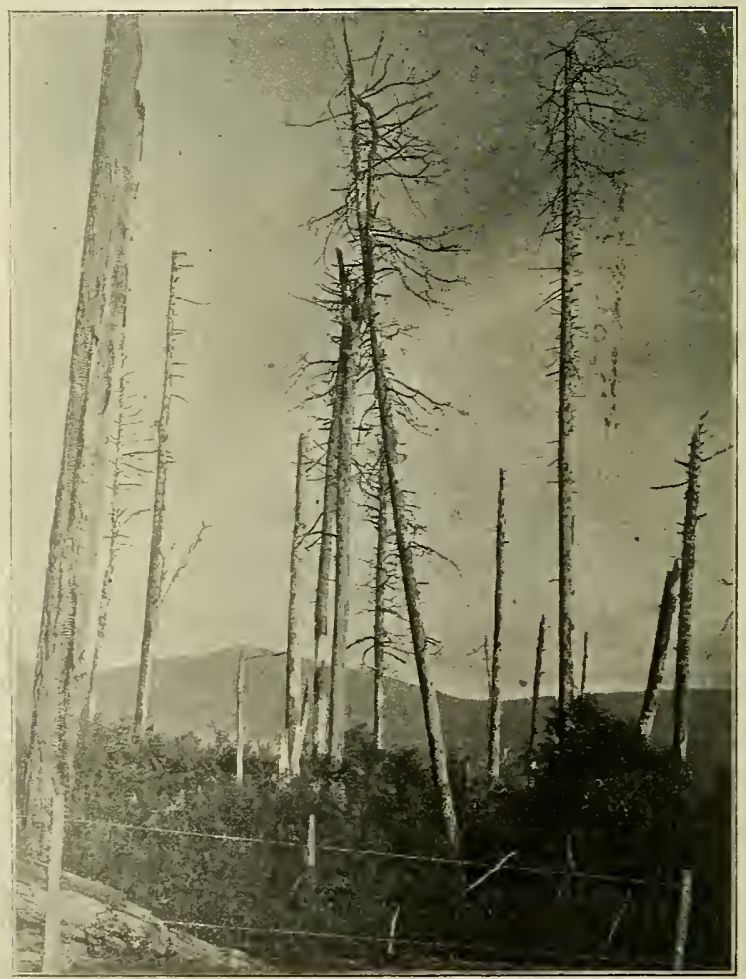

Fig. IX.-Remnants of a Great Spruce Forest, Cannan Valley. 
festing insects and other enemies of the forest, which within a few years-as we have had abundant evidence in the destructive invasions of the pine bark beetle-are capable of devastating the timber on hundreds of square miles. (Fig. IX).

This natural process of destruction of timber by wind, by fire, by disease and by insects, was continued, varying in its extent with the dry and wet, cold or warm seasons. To this was added the early and continued practice by Indian and white hunters, of burning over extensive areas to facilitate the procuring of game. Thousands of acres of these "hunter's burnings" may be found now in the heart of the spruce region, denuded of every vestige of timber. I have myself observed single sections of over a thousand acres thus denuded, upon which there was not a trace, not even a stump of the dense forest that once stood on the ground, the greater portion of the surface being covered either with a thick mass of ferns, mountain blackberry or blue-grass.

\section{MOUNTAIN PASTURES.}

Another destructive agency has been the clearing of large tracts in the midst of the wilderness of the spruce area by means of a system known as "hacking," for the purpose of obtaining

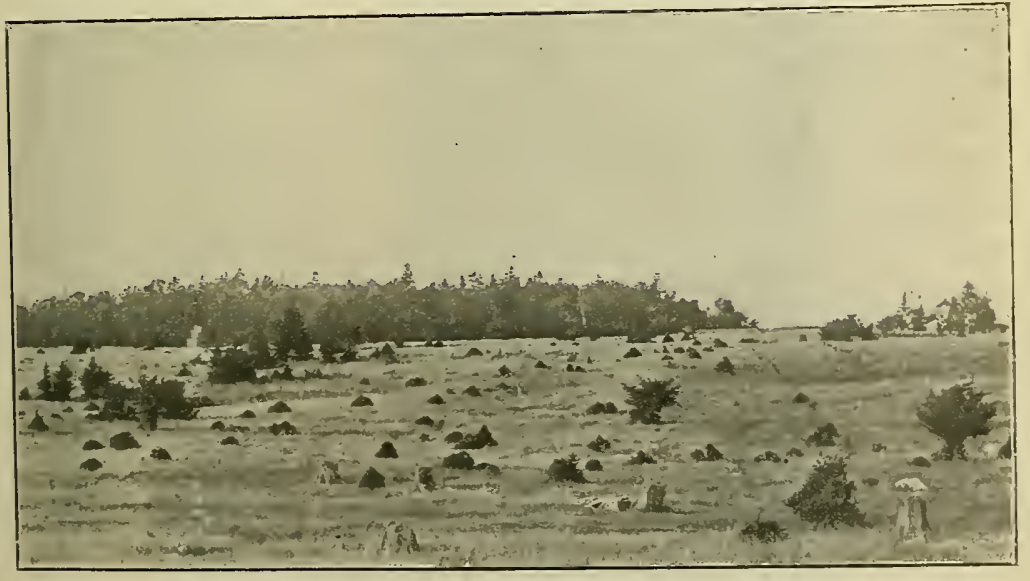

Fig. X.-Mountain Pasture with young spruce and white thorn, the latter pruned by cattle; altitude 3,000 ft.; near Pigeon Roost, Grant County. 
WEST VIRGINIA EXPERIMENT"STATION.

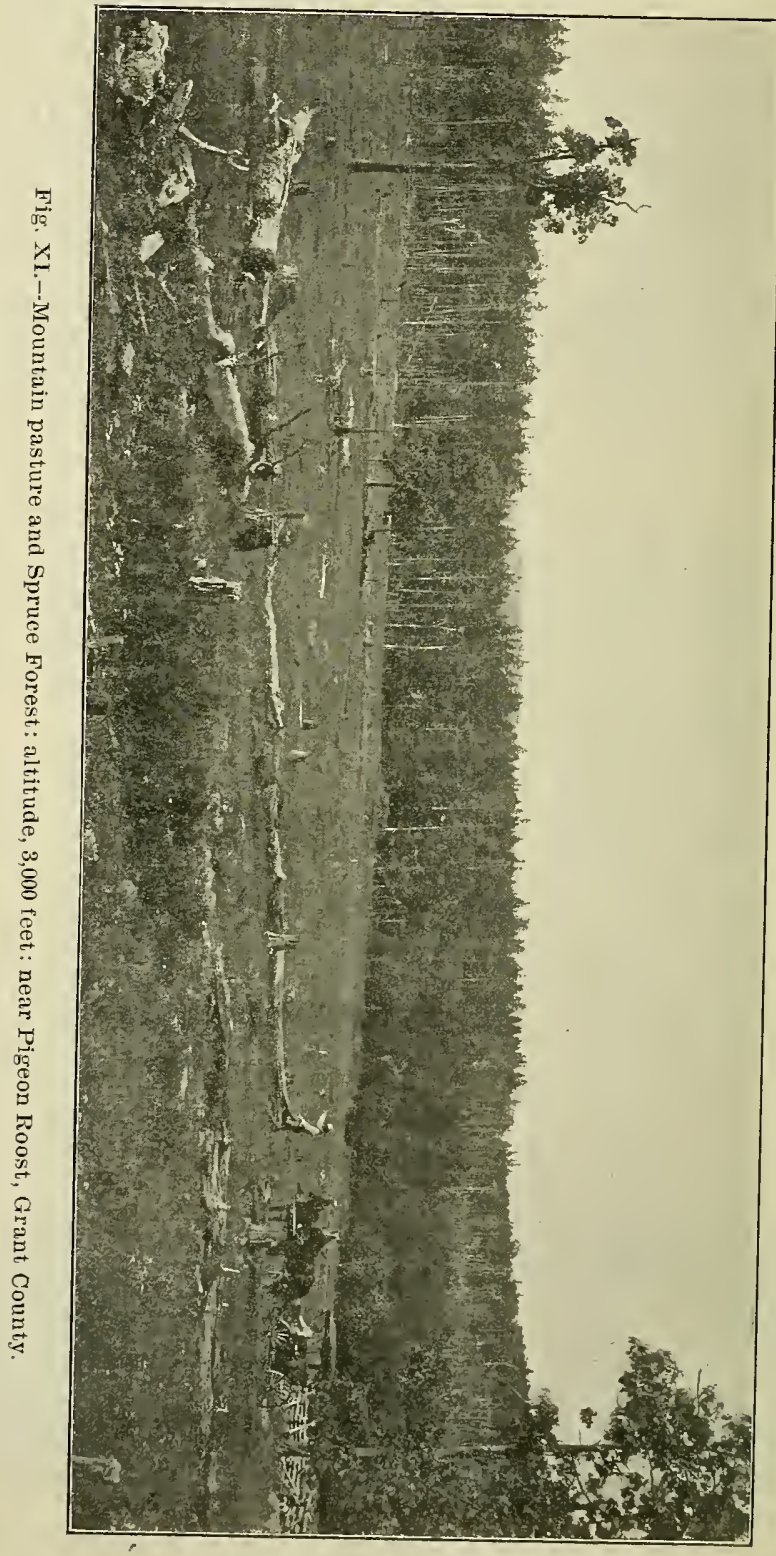


pasture for cattle. (Fig. X.) Farmers living fifty to seventy-five miles distant from the fertile limestone regions throughout the eastern and southern portions of Randolph and northern portion of Pocahontas counties came in to this spruce wilderness and purchased from the original owners, large tracts of land, paying 25 to 75 cents an acre for it, usually selecting the higher plateaus where, in addition to a fertile limestone soil, the land was reasonably free from surface stones. They would then proceed to girdle all of the timber on the best land and leave it to die. In a few years after the timber had been girdled these hackings were burned over to kill the-under-growth, and to get rid of the fallen timber: This was usually all that was necessary to make the conditions favorable for a natural growth of blue grass, which soon occupied the land. Then the cattle were driven into these mountain pastures, from the distant farms, to be left in charge of a herder luring the summer months. In the fall those suitable for beef were driven to market and the others returned to the farms. By these hunting and pastoral methods large sections where the best spruce grew have been denuded and a subsequent growth of timber prevented. (Fig. XI.)

\section{THE ORIGINAL AREA GREATLY REDUCED.}

Thus, I would judge that the spruce area up to about the year 1865 has been reduced to a belt averaging about twenty miles wide and one hnndred and eighty miles long, or an area of about 3,600 sq. mi., on which not over one-half of the total forest growth was spruce, or an equivalent to perhaps 750,000 acres of nearly pure merchantable spruce timber.

Within the last thirty years the spruce in this region has been greatly reduced by destructive insects, by fire, and by the lumberman until the total merchantable spruce timber now standing in the State in 1895 would not, according to my estimation, based upon original observations and accessible statistics, be equivalent to much over 225.000 acres of pure spruce forests, averaging 15,000 feet of lumber to the acre. While this may be considered a large amount of timber, it was a great reduction from the probable original $1,500,000$ acres and the recent 750,000 acres. (Fig. XII.) 


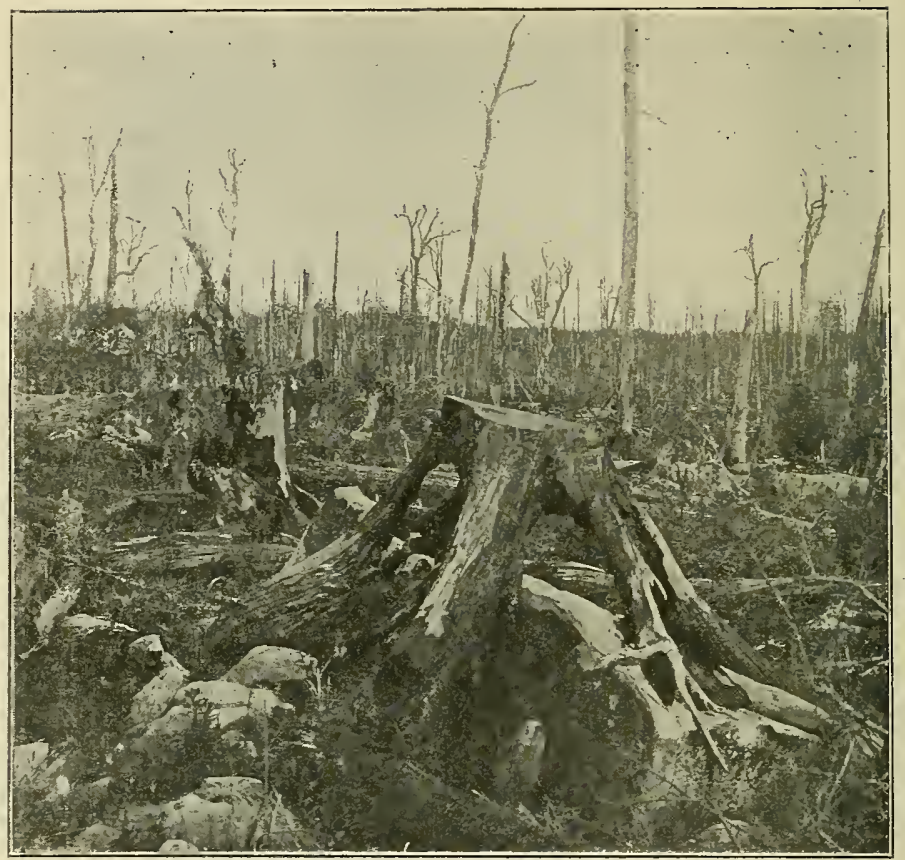

Fig. XII.-Spruce Forests cut over and destroyed by fire, near Davis.

PRESENT CONDITION IN THE SPRUCE AREA.

A study of the present conditions in the Spruce Area is in many respects of especial interest, furnishing as it does a typical example of the influences exerted by progressive industry in the developmeut of natural resources, upon the plant and animal life, climate, etc., and the consequent disturbance of nature's law in bringing about changed condition. The virgin forests of this area are mainly restricted to the more inaccessible portions of the rocky or swampy condition of the soil which has rendered them undesirable for pasture lands, unfarorable for the origin and spread of forest fires; or for the operation of lumber or timber companies. Thus, we find sections of greater or less extent throughout the south-western portion of Mineral, 
western portion of Grant, the eastern portion of Tucker, Preston and Randolph, western portion of Pendleton and the northeastern portion of Pocahontas county, and on the higher elevations of Webster and Greenbrier counties, where reasonably healthy and almost pure spruce forests occur. We also find in this same region areas from one to a thousand acres or more in extent on which all of the spruce timber has been killed by insects or other causes. Much of the timber is yet standing, lowever, and that which has recently died will remain in fairly good condition for the manufacture of timber and pulp for a number of years.

The spruce is the principal tree in the northern section of the area, while the other typical evergreen forest trees are hemlock, (Fig. XIII) white

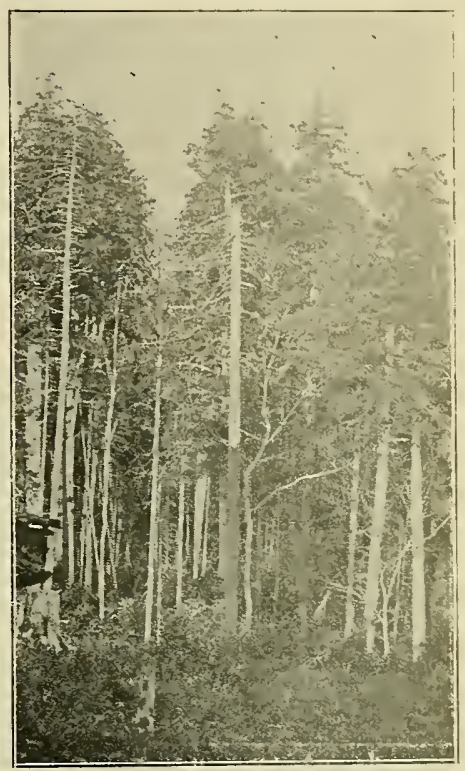

Fig. XIII.-The edge of a Hemlock Forest in Cannan Valley. pine and balsam fir, and two or three other species of pines. The hemlock is abundant throughout the area, in some places occuring in pure forests, but as a rule, mixed with spruce and hardwood. The white pine is common in the sonthern section. while the fir occurs only in the swampy plateaus of the southern portion of Randolph county. In the north-western edge of Preston there is a small area occupied with a mixed growth of spruce, larch and an occasional red pine. Among the deciduous trees which are classed with the hardwood, the birches and beech are the most common; the black, cheery frequent, mixed with the spruce, and the soft and hard maples common, while the white and red oak and tulip poplar are frequent on lower elevations.

Within recent years extensive lumber manufacturing com- 
panies have removed the spruce and other timber from large sections in Mineral, Grant and Tucker counties, and on Dry and Shavers Fork of Cheat in Randolph county, and are rapidiy extending their operalions into the remaining primitive forests.

The greatly improved facilities for getting out timber and manufacturing it into lumber and pulp makes it possible for the several companies operating in this portion of the spruce belt to remove and manufacture the timber from thirty to fifty acres every day in the year.

With the improvements which enable them to handle this immense daily cut of timber there are also improved methods of preventing waste, and of utilizing all of the spruce as well as

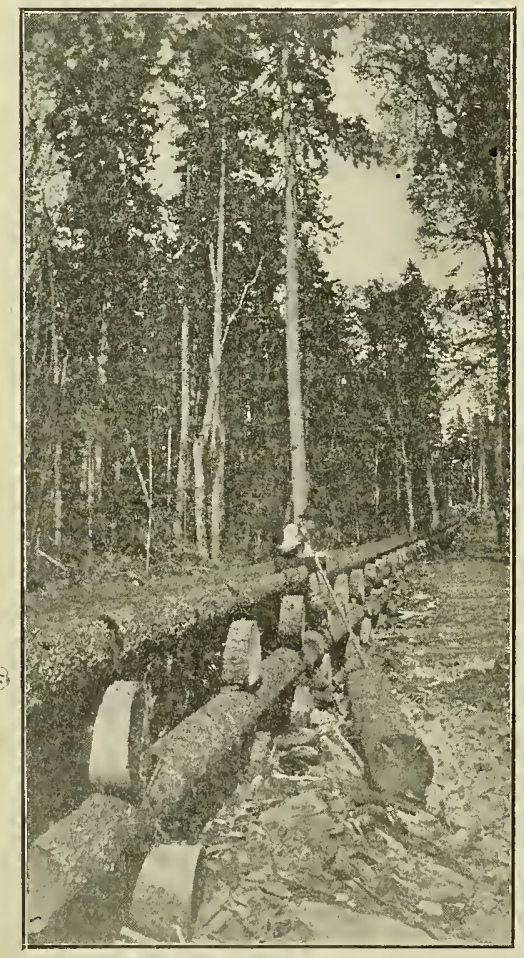

Fig. XIV.-Log Slide, extending from top of mountain to Shaver's Fork of Cheat. the hemlock and hardwood, thus preventing the immense loss which would otherwise be caused by the almost inevitable conflagration that follows the extensive cuttings in these dense forests. It is now the practice of the principal operators to take everything in the way of timber in their path of operation that is of any value, and as soon as one section is thoroughly gone over, they push on to another. The logs and other rough ma. terials are often transported many miles from different directions to the central manufacturing point, by means of $\log$ trains on narrow and broadggauge railroads, which, are built at great, expense for this pur. 
pose. In some sections, notably on Shaver's Fork of Cheat, the logs are transported from mountain sides and summits by means of log slides. (See Fig. XIV.)

Thus, in worked over regions we find the first year a labyrinth of $\log$ roads, $\log$ slides, and railroads through the standing laurel ; and between immense piles and windrows of spruce tops, old logs, broken trees and brush, a perfect harbor and hotbed for myriads of wood and bark infesting insects. The species of insect that would otherwise attack the ilving timber are attracted to the more inviting, recently felled, trees and tops found here and to the partly green stumps where they breed and inultiply, and in turn furnish abundant food for their natural enemies. Many kinds of the bark and wood infesting species which develop broods of young the first season, migrate to fresh cutting where they are followed by their enemies, while those that are more tardy in their developments remain in the old cuttings until the following year, before they emerge, or they are caught by the fire, which sooner or later claims this mass of inflammable rubbish.

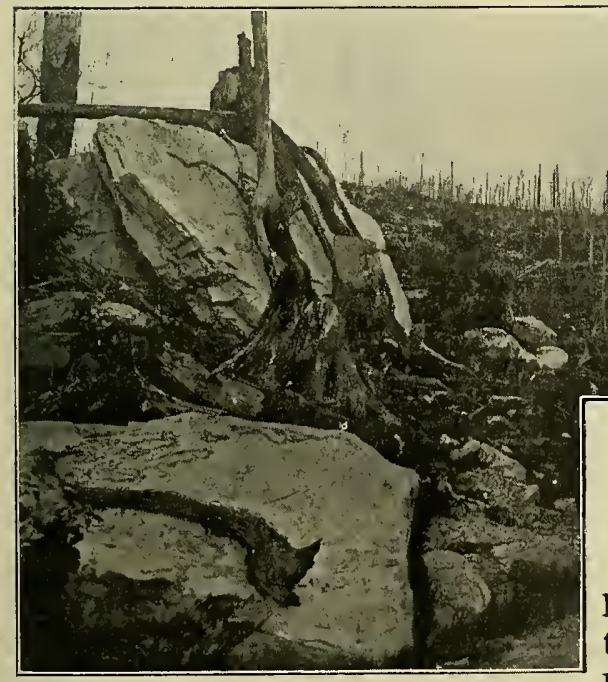

Fig. XV.-Rocks on which Spruce trees had grown, near Davis.

After the fire has once passed over a cutting there is often nothing left but bare rocks, charred stumps and $\operatorname{logs}$, (Fig. XV.) presenting a most desolate appearance in contrast, with the previous luxurian growth . 
The future condition of areas thus cut and burned over varies with the quality and condition of the land, and the frequency or non-occurrence of fires. In some sections where large areas present simply a mass of broken stones, no vegetation, except possibly a few straggling fire weeds and brambles, or a scrubby growth of fire cherry ${ }^{1}$ can survive. In other sections where more soil is mixed with the stones, and the land is undulating or level, fire or other weeds will spring up the same, or the following year, after the land has been burned over. These are succeeded by the growth of thornless blackberries, fire cherry, birch, etc., with possibly a few spruce and hemlock. If such places are protected from fire, the worthless fire cherry usually takes possession of the entire surface and crowds out every thing else. Where the soil is of a better quality a growth of spruce, birch, hemlock and sugar maple will follow the weeds and briars, and if protected from fire may produce a second growth of valuable spruce and other timber. In sections where the land is of good quality and well drained, and has been burned over a few times, a luxmriant growth of blue grass will spring up and take possesion of the land, especially if stock is allowed to run over it. In other wet and poorer sections the land will be covered by a dense growth of large ferns.

Therefore, under existing conditions there appears to be poor prospects of these worked and hurned over areas ever producing, naturally, a profitable growth of timber. With a little care and systematic management, however, much of the land which is absolutely worthless for anything else of value, could be made to produce a dense growth of spruce (Fig. XVI), and other timber, which would, within 25 or 30 years, begin to yield profitable returns in pulp wood, and in 50 to 100 years it could all be cut for pulp and lumber.

The typical spruce or pine forests in the southern, eastern and southeastern portions of Randolph, and in Pocahontas, Webster, and Greenbrier counties, are in fairly healthy con-

1 Prunus Pennsylvanica $L$. 


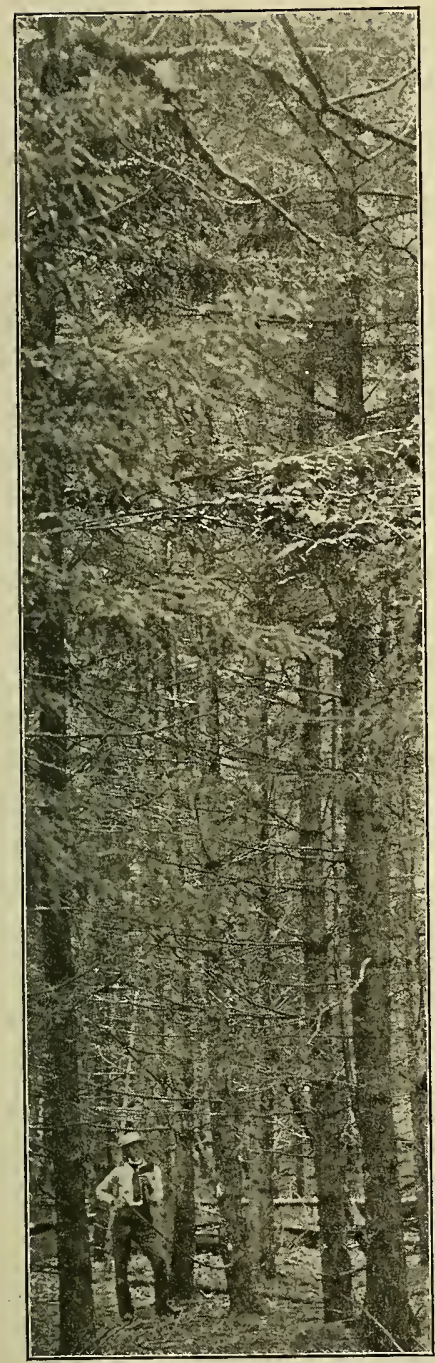

Fig. XVI.-- Young second growth Spruee, on border of Moun tain Pasture, Grant Co. dition, and have not, as yet, been invaded by the lumberman. I'reparations are being made, however, to commence operations here at an early date, when tho same results as those we have mentioned are almost certain to follow.

PROBABLE FUTURE OF THE AREA AS INDICATED BY PKESENT CONDITION.

Tracing the history of the spruce from the time when it possibly beld undisputed possession of nearly all of the West

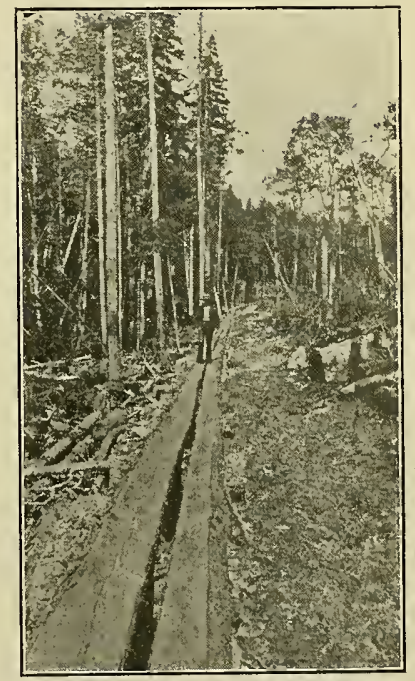

Fig. XVII..-Log Slide and Spruce Timber.

Virginia area, through its struggle along with the other hardier evergreens, to hold possession during the ice age, its effor ts to 
occupy the land left by the receding waters, ${ }^{1}$ its struggle for existence with the hardwoods and pine, and its final retreat to the higher elevations where it occupied the land previously held by the more hardy spruce and flrs, and while those that remained on the lower elevations were giving up the land to the victorious oak, yellow poplar, birch and hemlock, the main body of the spruce finally held its own on the higher elevations until tie aavent of civilization, when it found a new enemy in man, and through his influences in clearing the land, in the resulting forest fires and insect invasions, we find it reduced to its present narrow bounds and mutilated condition, it would appear that this remnant and living example of .. the greater primitive forest is destined to follow the prehistoric races of men and animals which have long since been banished from the land.

Whether or not this theory of the history and progress of the destruction of the spruce is correct it is at least suggestive of the probable truth, and will indicate what its future will be unless the same influences, through the agency of man which have brought about the gieatest recent destructions, are con. trolled and directed so as to bring about reversed results. Still further evidences of the possible future condition of the region may be had from the history of similar regions in some of the older countries of Europe, where a continued system of destruction of the forests with no attempt at systematic protection, or renewal, has resulted in the transformation of rich and productive regions into desert wastes, and has, in some cases, even contributed to the reduction of powerful and prosperous nations to a condition of dependence and poverty.

We also find abundant records of other examples in the forest regions of Europe, where by a judicious and economic system of management the timber on similar areas has been increased and its productive capacity doubled, and at the same time has furnished continued and profitable returns in merchantable products. As a consequence, the country main-

1 According to Dr. I. C. White a large part of the low lands of the State was inundated during the ice age. 
taining such a system has made rapid advancement in all of its industries, and become influential and prosperous.

History will doubtless repeat itself along one or the other of these lines in the spruce area and other typical forest areas of our State. Which one will be followed, and what the final results will be, depends: First,-Upon further investigations within the near future by a commission of scientific and practical observers who are especially fitled for the purpose, to determine biological, geological, agricultural, horticultural, commercial, meterorological and entomological questions which have a direct bearing upon the conditions and needs of this and other distinctive forest areas of the State; Second,-Upon the interest the owner of the land and the general public will take in'an effort to introduce some practical system of forest management, and the aid and encouragement a movement of this kind will receive from them; Third,-Upon the additionat aid and encouragement the State or general government will extend in furthering the objects of such movements; Fourth,Upon the individual owners of the land and the object and interest they may manifest in the immediate or distant future; whether through necessity or otherwise, they deem it important to avail themselves of present opportunties, and realize, to the fullest extent, on their investments, regardless of future conse. quences; or whether through an interest in posterity, in the welfare of their State, or in future profits, it is their object to perpetuate the wealth they possess in natural forest resources. COMMERCIAL INFLUENCE IN THEIR RELATION TO THE FUTURE OF THE SPRUCE AREA.

T'he cutting of timber to be conver'ed into merchantile products, the clearing of land for the purpose of obtaining merchantable agricultural products, the opening of coal, iron and other mines, the improvement of streams and the building of railroads for the transportation of these various natural products to market, is exerting a marked influence upon the distruction of the spruce. (Fig. XVIII.)

The conversion of the forests into merchantable products ap- 
pears to be if not a necessary evil, an unavoidable one. Capital represented by corporations, companies and private individuals has been invested with a view of realizing early profits

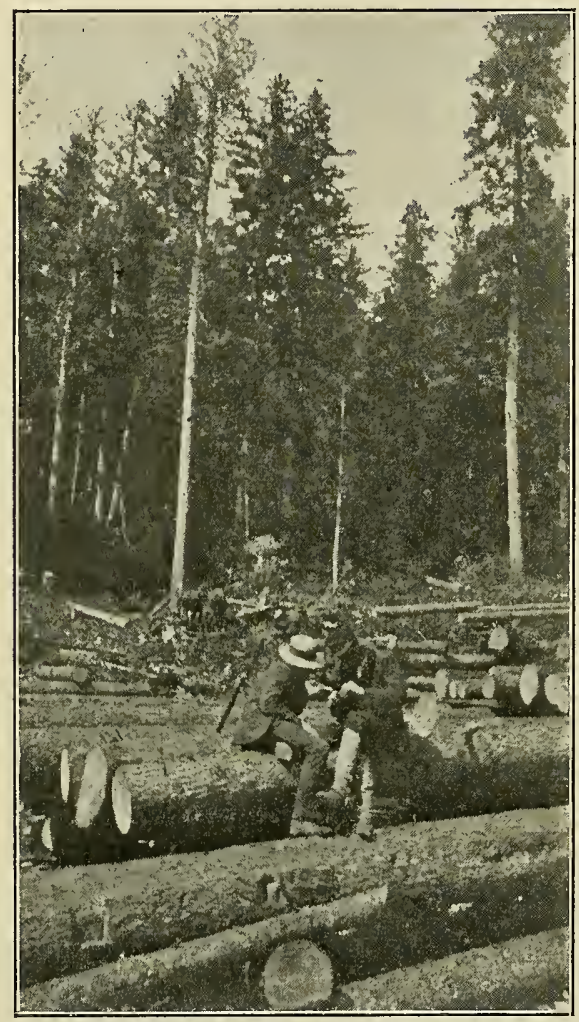

Fig. XVIII.--Spruce timber. skidway and log slide near Cheat Bridge, Randolph county. on a greater part of the land covered by forests in this area. Numerous large manufacturing plants have been located at different points within the area, which together, with other's at a distance in this and other States a re dependent upon the forests here for their r a w materials. The capital invested in land and timber manufacturing plants, working force and transportation facilities is enormous, and as a nccessary consequence these investments must be kept actively employed in order to vield an interest and profit on the investments. Thus, the demand upon the forest resources is correspondingly great, and under present conditions must be supplied regardless of future consequences to the land or the State.

This is the existing conditions which; I believe is not fully realized by persons who are considering the subject of low the destruction of our forests may be prevented. It appears to me to resolve itself into questions of how long the timber will last, 
how may present losses from insects, fire, and other causes be prevented, and how can the loss of these forests be best repaired?

\section{AGRICULTURAL INELUENCES.}

The high altitude and rongh character of the land of a large portion of the mountain regions of the spruce area is such that it cannot be used in agrirultural pursuits for much else than pasture for sheep and cattle. There is, as previously stated, large sections already utilized for this pnrpose, and when we take into consideration that much of the uncleared or forest land wll be admirably suited to grass and to pasture ranges when the timber is removed, it is evident that as the timber is removed by the lumberman, and the fire cleans up the rubbish and destroys the underbrush, the pasture area will rapidly increase and finally cover a large portion of the land included in the spruce belt. If so, this will have a marked influence in preventing a second growth of spruce upon all of the best land, and in restricting the forests of this timber to extremely narrow bounds.

If these pasture areas are properly utilized and cared for, it will, in a measure, compensate for the loss to the state of the forest wealth that is removed, since the quality of mutton these mountain pastures are capable of producing, should make the breedung and rearing of mutton sheep a leading industry and be a perpetual source of wealth to the owners of the land, as well as to the State, and to a limited extent and under proper management it will do so. But in this process of converting the good land into pasture and the attending consequences resulting from the destruation of young second growth spruce and other valuable trees, by sheep and cattle, which, together with the rocky slopes and entire mountains which have been converted into barren wastes by fire and water after the timber was removed, there is great danger of serious consequences to the entire region.

This extensive removal of the forest, and with it its protective influences and resulting exposures of such large pro- 
portion of the surface to the action of the sun, drying winds and floods, would have the effect of drying up the streams and springs, and reducing the general moisture of the air and soil. This, together with the large area covered by sod, would offer favorable conditions for the multiplications of insects which breed in, and are destructive to the sod, and in connection with long continued drouths, much of the sod would be destroyed by them. The dead and decayed sod would expose the soil to the eroding action of heavy rain storms. The destructive floods and torrents which are inevitable consequences of clearing the forest growth from mountain areas, would carry the soil away from the highlands and devastate the valleys, so that the final result, so far as agriculture is concerned, could easily become a poverty stricken and practically irreclaimable region.

Whether or not this deplorable condition will be realized, depends as we have already indicated upon the owners of the land, and the interest they will take in the future of the forest area of the State. I do not think it will come to the worst, but nevertheless, it is a possible condition for present residents of the region to keep in mind and guard against.

THE IMPORTANCE OF PERPETUATING THE FOREST RESOURCES OF THE AREA AS A SOURCE OF WEALTH TO ITS INHABITANTS AND THE STATE.

While the private and incorporated owners of the land and timber in the section of the State that we have designated as the spruce area, have a perfect right to do as they like with their property, and while it is proper and advisable to develop and utilize the matured forest products, it is even more important that the present owners, their successors and the State should make some provisions for the perpetuation of the wealth of forest resources in this region, and thus prevent the disastrous results which are sure to follow a total destructions of the forests without an attempt at reparation.

It has been stated by good authority that 20 to 25 percent. of a country should be covered by forests as a necessity. It is evident, however, that the spruce area in which nearly all 
of the water ways of the State find their first source of supply, should, in order to preserve normal, climatic and other conditions, have 50 to 60 per cent. of its surface covered by perpetual forests.

I would judge that not much over 25 per cent. of the area is at present bare of timber, including land utilized for agricultural purposes, and that denuded by the timberman and by fires. This would leave 75 per cent. covered with forest growth, including the original, or virgin forests, and that cov. ered by second growth in worked over or burned over sections.

If it takes 50 years to work up, or in other words, harvest the merchantable timber of all kinds now standing in this area, and at the same time, proper attention is given to the protection of the young and second growth, it is possible to perpetuate the forests indefinitely. At the same time it can be made to yield an annual cash income that will justify the effort, to say nothing of the general benefit the agricultural and other interests the State will derive from the perpetuation of this large percent. of forest covering. Yet, while it is possible to perpetuate this wealth in natural forest resources, will it be done? This depends upon the action of the present owner, their successors, and the general public or State.

As to present owners, consisting of resident farmers, resident and non-resident real estate speculators, manufacturing and transportation companies, it is evident that the actions of some of them will tend to prevent the perpetuation of this wealth, especially those who intend removing to other sections of the

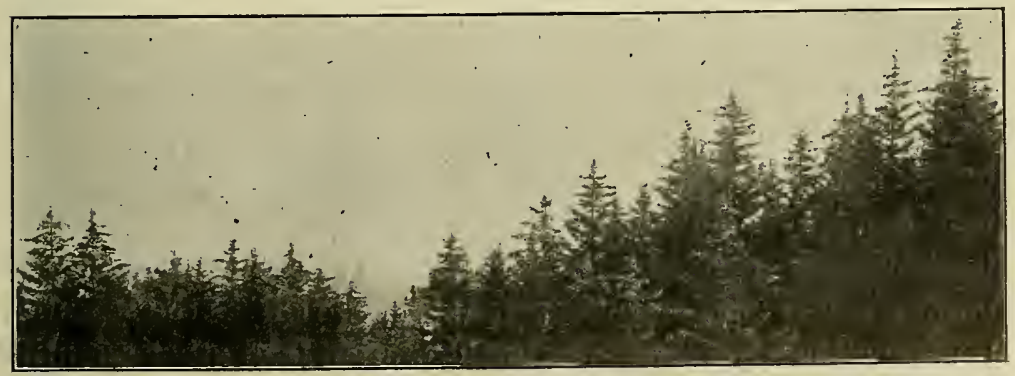

Fig. XVIII $a$-Tops of Young Spruce Forest on border of Mountain Pasture. 
State, or to other States, as soon as they have disposed of, or worked up present holdings. There is another class of owners, however, among the permanently located manufacturing, mining and transportation industries, especially the latter, who are interested in future supplies. as well as in that of the present, and as they come to fully realize the importance to them of a future supply of timber, they will give the subject due consideration, and will heartily encourage any movement that will aid in the preservation and perpetuation of this, one of their principal sources of necessary supplies as well as of wealth. Fortunately, this is a class that is capable of accomplishing the desired end, since it has among its representatives in the State public spirited and able men like Hon. S. B. Elkins, J. N. Camden, H. G. Davis, and a number of others who are not only interested in the future of their personal investments, but in the future prosperity of the State as well. Thus, it would appear that this class of owners can be depended upon to con. tribute to the perpetuation of the forests upon the greater part of the area under their control.

That this question of perpetuation of present forest values is of vital importance I think no one who is interested in the future welfare of this region and of the State can doubt. But as to how this desirable end is going to be accomplished is not so clear.

This is indeed a complicated problem, involving as it does an economic system of harvesting the matured crop of the valuable timber; the preservation of the young growth in the original forests; the reforestation of denuded and abandoned areas with a desirable second growth, and when practicable the planting of desirable kinds of trees on the land that will not produce a natural second growth. It also includes the most serious and difficult problems of all, that of protection against forest fires and the invasions by destructive insects. It is in fact a question demanding serious, consideration by resident land owners, permanently located manufacturing concerns, mining and transportation companies as well as the scientific investigations by the Experiment Station and other scientific workers, representing a number of different branches of science. 
It is also a matter in which the general public and the State Legislature can'well afford to take some interest and extend aid towards protecting and perpetuating this, one of our richest natural resources of wealth.

Whether or not this object can be best attained through a system of reservation or game preserves controlled by the Federal or State Government, by manufacturing and transportation companies, sportmen's associations and private individuals, or by some other means, remains to be determined by further study of the conditions. It is very evident, however, that the time is at hand for the question to be agitated, and an effort made to bring about some system of concerted action that will prevent the total destruction of the forests and the cunsequent loss of State wealth.

THE RELATION OF ENTOMOLOGICAL RESEARCH TO THE PRESERVATION AND PERPETUATION OF FORESTS.

Investigations for the purpose of solving the problems which have reference to methods of protecting young and old timber from injury or destruction by insects will form an important feature in any scheme for the protection and perpetuation of

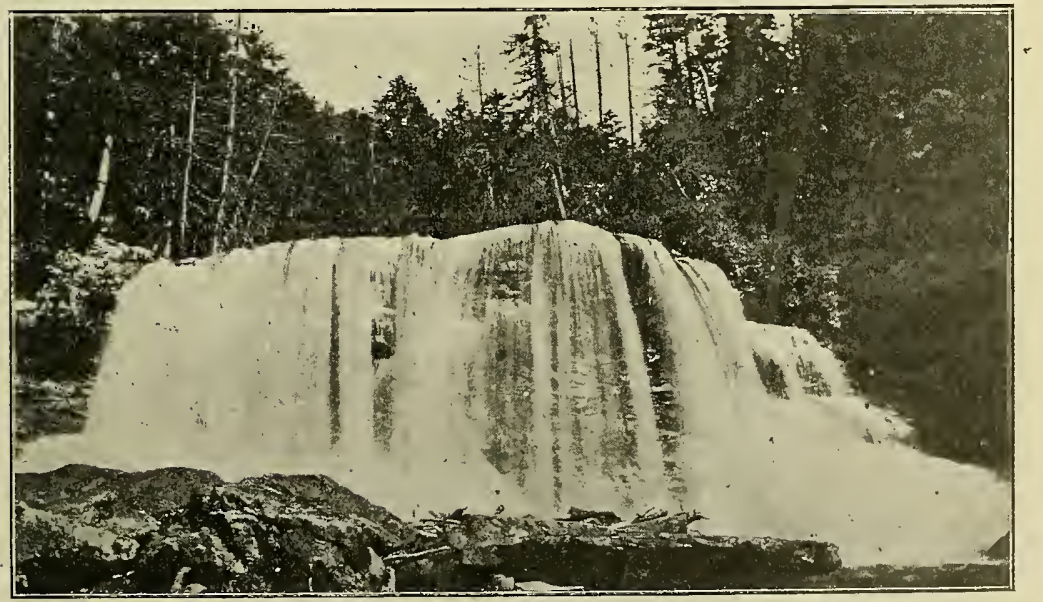

Fig. XIX.-Falls of Black Water, $80 \mathrm{ft}$. wide, $60 \mathrm{ft}$. high; in Spruce Forest near Davis ; altitude $3.000 \mathrm{ft}$; described by Port Crayon in Harper's Magazine, in 1857. 
the forests in this and other regions of the State. Therefore, the subjects of past and present distribution and condition of its forest trees; the animate and inanimate influences which have affected the conditions of its plant and animal life, its wealth in forest resources, its possibilities and its probable future have all been considered and studied mainly in their relation to entomological research.

REPORT ON INVESTIGATIONS TO DETERMINE THE CAUSE OF THE UNHEALTIIY CONDITION OF THE SPRUCE BETWEEM 1880 AND 1893.

A preliminary report on the black spruce investigation was published in the Third Annual Report of the Station, pp. 93- 102, and in Bulletin 17, as a reprint from the Annual Report, dated May, 1891. After this report was submitted, the investigation was continued and a number of special trips made through the spruce region for this purpose, in the following months and years: March, 1891; July, 1891; May, June and July, 1892; May and July, 1893; May, July and October, 1894.

All the principal sections of the region, where the spruce predominated, were visited, and a pretty thorough study made of the conditions of the region and its timber, which is referred to in another part of this report. Much additional information and new facts have been obtained upon the insect infesting the spruce, but as a considerable portion of it is of a technical nature, I will simply mention in this report, some of the leading features of economic interest, and reserve the other for a more detailed special report on spruce tree insects.

I am now able to bring together a chain of data and evidence upon which to base more definite conclusions than was possible when Bulletin 17 was published.

\section{DISTURBING INFLUENCES.}

The earliest record we have of disturbing influences in the spruce forests, which would offer favorable conditions for the increase of destructive insects, was the hunters' burnings, pioneers' clearings and stockmans' hacking during the first half of the present century; also that resulting from the cutting of spruce timber, (about 100 acres,) around or near the Dobbins 


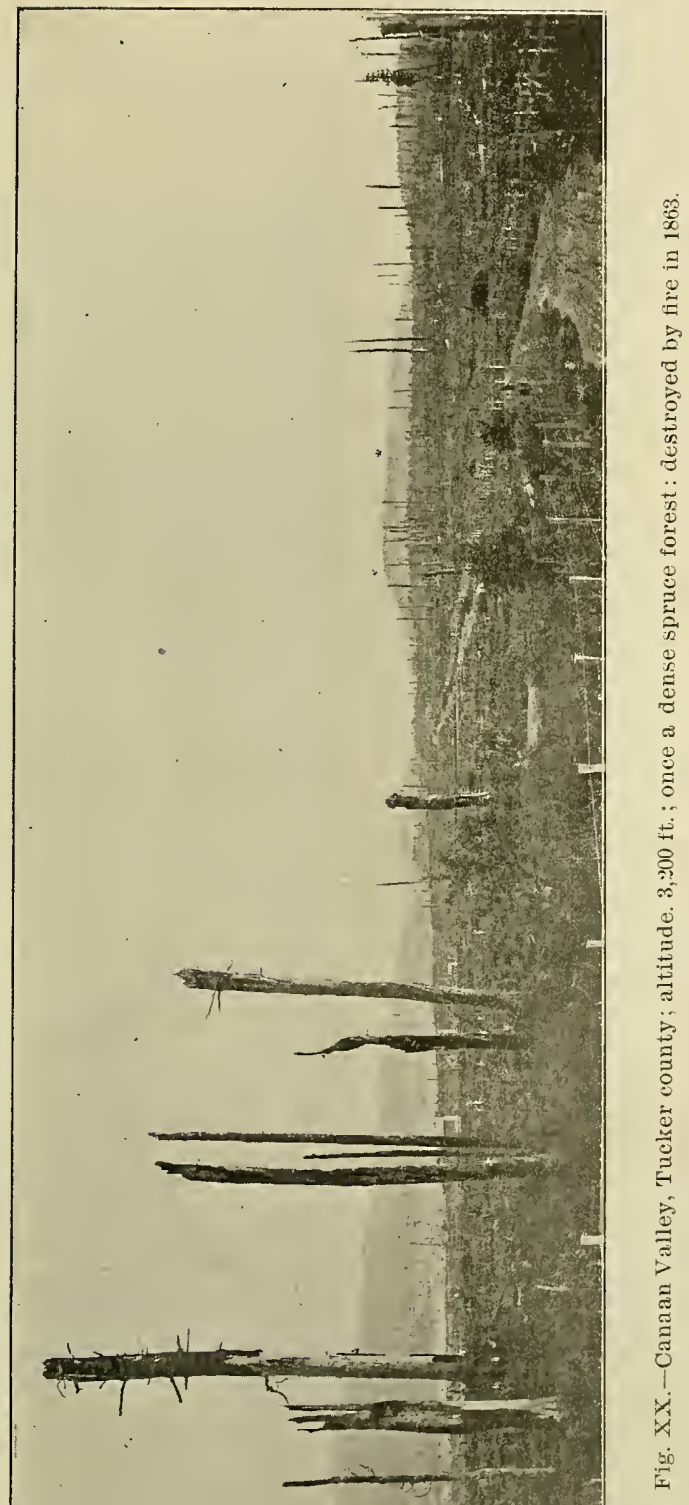


mansion, in Tucker county, which was built by Judge Dobbins in 1856 , for a private summer and hunting resort.

In 1863 there was a great forest fire in the Canaan Valley, which caused the death of the spruce timber on thousands of acres of land. Other like "burnings" started by hunters, destroyed large areas of timber in different sections of the spruce region up to 1885 .

In 18977 a great storm commencing near the Dobbins mansion and proceeding in an easterly direction, through the heart of the spruce forest in Tucker county, cut a path 50 to $400 \mathrm{y}$ ards wide, and 6 or 8 miles long through the timber. Subsequent fires started in this windfall caused extensive destruction of timber.

In 1881 and 1882 the timber along the survey of the W. Va. Central R. R., was cut to Fairfax, in Grant county. A cutting was also made here in $18 \$ 1$ to build camp Midway, which was occupied by the cutters. This was followed by dying timber in 1883 and 1884.

In 1882 it is reported that the region suffered from a severe drouth, followed by a wet season in 1883 .

In 1883 the timber on the railroad survey was cut to Davis and the railroad finished to that point in 1885 .

In 1884 a cutting of about 40 acres was made near Davis, and an extensive burning was made in the windfall of 1877 .

In 1884 extensive timber operations were commenced in the spruce on Shaver's Fork, of Cheat, in Randolph county, which has been continued to the present time.

In 1885 the timber was cut from the land where the town of Davis stands.

Soon after the W. Va. Central Railroad was finished to Davis and Elkins, numerous and extensive lumber operations were commenced in Grant, Tucker, and Randolph counties, which have increased each year to the present time.

In addition to all of these disturbing influences several severe drouths have occured in the region since 1882.

HISTORY AND PROGRESS OF DYING SPRUCE TIMBER IN THE SPRUCE AREA.

The earliest information I have been able to obtain with 
reference to extensive dying of spruce timber was that from Col. E. Hutton, who stated that the timber commenced to die in the Cheat region, (Shaver's Fork of Cheat) between 1880 and 1882, while Mr. Hambric fixes the date as October, 1852, for the same locality. ${ }^{1}$

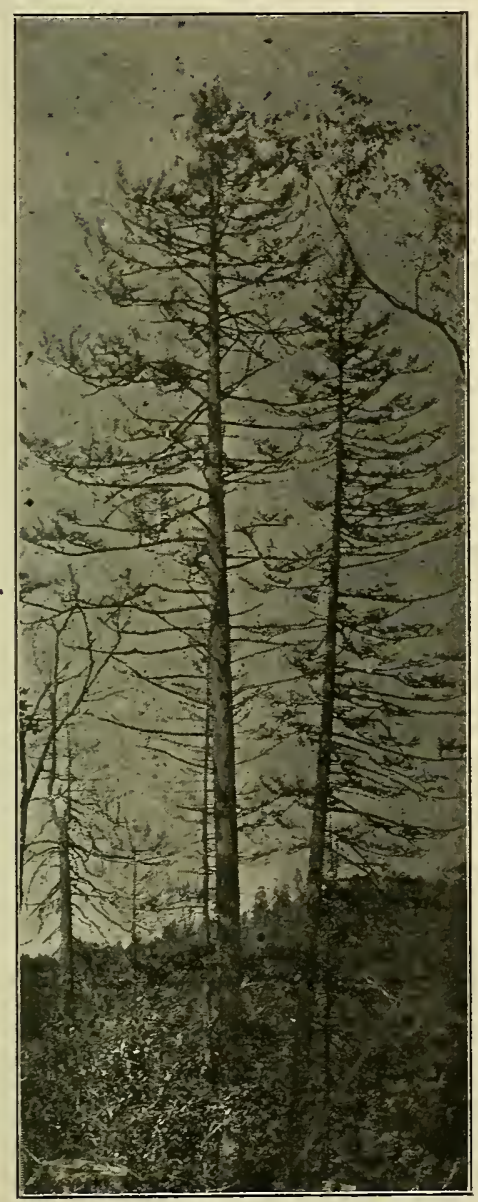

Fig. XXI.-Dead Spruce Timber, near Cheat Bridge.
In $18 \$ 3$, the men that were cutting and pealing spruce timber along the survey between Fairfax and Davis, found the green bark filled with little worms and bugs,: and in $18 s 4$, the timber was found to be dying along the railroad. ${ }^{3}$ It is therefore evident that the timber commenced to die in this legion in 1883 , and possibly in 1SS2. We have anolher statement, however, that there was scarcely any dead timber in the Blackwater region in $18 \& 4$ and $1885 ; 5$ and another statement that the first timber was observed dying here in $1886 ;{ }^{6}$ while others say that it com. menced in 1857. Capt. Parsons, however, had a better opportunity in the pursuit of his duties as civil engineer, to observe the conditions, and we are inclined to believe that he is nearer correct than the others, and that it really commenced to die here in

\footnotetext{
1. See also Bulletin 17.

2. Informaiion from Capt. Parsons,

3. Information from Mr. Ruffner.

4. Col. E. Hutton.

5. Blackwater Lumber Co.

6. St Laurence Lumber Co.
} 
1883. According to the most reliable information, the timber commenced to die in Pocahontas county, on the waters of the Greenbrier river, and in the adjoining portion of Randolph county, in 1883 .

All persons from whom I could procure information which was based upon their personal observations agreed that the timber continued to die for from three to four years afterit first began to attract attention, after which the trouble gradually, or suddenly came to an end.

The spruce timber commenced to die again during the spring and summer of 1892 , and in June of that year I made a thorough examination during an extended and tortuous journey on horseback and on foot, through the heart of the spruce wilderness, from Hendricks, in Tucker county, to Traveler's Repose, in Randoiph county, and on Williams river in Pocahontas county. All through the forest from the time the first spruce was observed on the point of the mountain, near the mouth of Dry Fork of Cheat, until we emerged from the forest near Traveler's Repose, on the Greenbrier river, clumps of dying trees were observed on the high points and on the eastern and western slopes of the Allegheny peaks and ranges, the eastern border of the spruce belt being affected far worse than the western portion. These clumps and patches of dying spruce trees, varied from a few trees in some places to all of the spruce trees, large and small, on several acres in other places. The same condition was also found in the spruce forests near the source of Williams river, in Pocahontas county.

In May and July, 1893, the investigations were continued in the spruce area in Grant, Tucker, Kandolph and Pocahontas counties, when it was found that no timber was dying except that which had been seriously injured by the trouble of 1892 , and in May, $J$ uly and October, 1894, the same and other sections of the spruce region were visited and no timber was found dying.

Numerous reports were received from different sections during 1893-94-95 that the timber was still dying, but upon careful inquiry and personal examiuations, I found that in every case, 
reference was had to the timber that died in 1892 , or that which had not recovered from the injury sustained during that year.

Thus, we have a tairly complete history of the progress of the two apparently distinct troubles which caused the death of an enormous amount of spruce timber. The one starting in 1882, and contiuuing until about 1886, the other starting in 1890-91 and ending in 1893.

\section{CAUSE OF THE FIRST TROUBLE.}

The origion and cause of the unhealthy condition of the spruce during the period between 1882 and 1886 cannot, be accurately determined, since no investigations were made during its progless, but from such evidence as could be obtained from the dead timber, and the existing conditions at the time of the fist investigation in 1890 , and a study of the habits of the various insects found in the bark of living and dying trees, to the present time, it appears that it must have been caused by insects.

The facts obtained in 1890, as recorded in Bulletin 17, seemed to warrant the conclusion that the destructive spruce bark beetle ${ }^{1}$ was the prime cause of the death of the trees, and that the trouble had been brought to an end by the influence of its parasites. The results of subsequent observations, however, have not furuished additional evidence that this would be a correct conlcusion. In fact, while I have frequently found the adult, eggs, and young of the spruce bark beetle in the living bark of injured or dying trees and recently cut logs, I have not, as yet, found it in the bark of a healthy vigorous tree. This failure to find it in the bark of healthy trees may be due, however, to its preference for the bark of injured and recently felled trees, and that the abundance of the latler in different sections of the forest since 1895 , has rendered it unneccessary that they should attack healthy trees; and in this might be found an explanation of the ending of the trouble in 1886 , since the increased cutting of timber in the northern as 
well as in the central section of the spruce area would have served to attract the beetles away from the living trees. The only objection to this theory that presents itself is my observation in 1890 , that the 1887 cuttings showed, in stumps and tops, less evidence of the abundant occurrence of the beetle during that year, than was found in the cuttings of 1884 and 1885. This may have been due, however, to the time of year the timber was cut, a fact that was not taken into consideration at the time.

It would therelore appear from our present knowledge of the subject that the destructuve spruce bark beetle, more than any other insect common to the spruce, may have caused the first trouble, and that the chain of circumstances which lead to its invasion of the healthy timber was as follows :

The disturbing influences of the first white settler's in the region, followed by the opening of roads through the spruce. wilderness, notably the Parkersburg \& Staunton turnpike, through the middle of the section, and the Northwestern lurnpike through the northern section of the region; the hunters' burnings; the clearing around the Dobbins mansion in 1856 ; the influence of the opposing armies in 1S61; the great fire in the "Canaan" in 1863 ; the windfalls of 1877 ; the hacking between 1860 and 1880 ; the opening of the $W$. Va. Central Railroad in 1881 to 1885 ; together with untervening severe drouths and storms, all contributed to favorable conditions for the multiplication of the species and its numerous allies, and the consequent destructive invasion.

It would also appear that the continued cutting of timber since 1885 , together with the increase of the natural enemies of the species, with possibly sudden changes in climatic conditions, was the cause of the trouble ending when it did, and that the first mentioned condition served, more than any other, to prevent the re-occurrence of similar trouble from the attack of this insect.

This conclusion will apply as well to any other of the same class of bark beetles which may have been the cause of the 
trouble, except the destructive pine bark beetle, which, it appears is not attracted to felled timber.

CAUSE OF THE SECOND TROUBLE.

While the causes of the first trouble appear to be satisfactorily explained, there is yet a certain degree of uncertainty, which, owing to the conditions stated, cannot be explained.

It is different, however, with the second trouble, or that of 1892, which I had abundant opportunity to investigate from beginning to end. The primary cause of its starting is clearly explained and may be briefly stated as follows:

In 1890, the pine timber was observed by the late Capt. Parsons, of Davis, W. Va., to be dying along $W$ arm Springs Mountain, Virginia, for a distance of 70 miles, and upon examiuation it was found that no cause for the trouble was apparent, except that the green or living bark was filled with "worms and bugs." Subsequently, this trouble spread into West Virginia, and was the subject of special investigation, and in May, 1892, I discovered that a bark beetle, somewhat similar to the destructive spruce bark beetle, but larger, was to blame for the death of the trees in the Easter Pine and Hardwood region. In June of the same year, the spruce was found to be dying, and upon thorough examination, the trouble was found to be caused by the same beetle which h:id migrated from the infested pine into the spruce, the attack on the spruce being made on the upper portion of the trunk, as was its habit in attacking the pine. A number of dying trees were felled and ex. amined from root to top, and in every case the prime cause of the diseased condition or death of the tree was easily traced to this insect, and it was also observed in the act of mining and depositing eggs in the inner living bark on healthy, vigorous spruce tress, leaving no doubt whatever ithat it was the prime cause of the death of the timber, and the starting of this new trouble. While the spruce bark beetle was its most ready ally, and was invariably found entering the bark of trees that had scarcely commenced to show signs of weakened vitality, there was always evidence that the destructive pine bark beetle was 
its benefactor in making the first attack. This fact, together with the clumps of dying trees to be seen in all directions, scattered throughout the spruce region, presented conditions that were really alarming. The pine beetle had already killed the greater part of the pine in Pendleton, Grant and Hardy counties. It was playing havoc with the white pine forests in Pocahontas and Greenbrier counties, as well as that in the southern section of the spruce area, and had crossed over the mountains and was spreading through the western part of the State; thus demonstrating beyond question its destructive powers. This, in connection with the known habits and suspected destructive powers of the spruce bark beetle, presented a combination of destructive forces which it was easy to see would cause the death of all of the spruce timber within a year or two, if nothing intervened to prevent.

A CIRCULAR LETTER TO LUMBER COMPANIES.

It was this condition of affairs that led me to issue on July $14 \mathrm{th}, 1892$, a circular letter to the owners of pine and spruce timber, calling their attention to the true character of the trouble, and suggesting the importation of beneficial insects as the only move that appeared to offer any possible means of combatting the trouble and of saving the healthy bodies of timber. (See copy on another page, Part II.) Response was made to this circular letter with liberal contributions of money, from the W. Va. Central \& Pa. R. R.. a company which contiols or owns large bodies of spruce timber in Randolph, Webster, Pocahontas, and Greenbrier counties; the Condon Lane Bonm $\&$ Lumber Co., then owners of one of the finest and largest bodies of spruce in the State, on the waters of Cheat, Potomac, and Greenbrier rivers ; and the St. Lawrence Lumber Co., owners of sprace on waters of Greenbrier river: which, together with contributions from other companies interested exclusively in pine, and a like-appropriation from the Station funds, made it possible for the writer to conduct the experiment of importing beneficial insects, which is referred to in detail in the report on pine investigations. 
DISTRIBUTING THE EUROPEAN BARK BEETLE DESTROYER.

In May and June, 1893, I located colonies of the imported beetle in the spruce forests on Williams river in Pocahontas county, and on the Dry Fork of Cheat, in Randolph county. During the first trip for this purpose, in May, I discovered that the destructive pine bark beetle, in a large number of pine and spruce trees examined, were dead in their mines, in the bark. Dead examples of all stages of the insect, from eggs to adult,were found in great numbers within the bark, but not a living example could then be found, nor have I since been able to find a single living specimen in the State, up to the present writing, (January: 1896.) ${ }^{1}$

END OF THE TROUBLE.

When the destructive pine bark beetle was found to be dead in all of the trees that had died the previous fall, 1892, and winter of 1893 , I announced it as my belief that the trouble was over, and with the exception of a comparatively few trees which were serionsly injured by the insect in 1892 , and subsequently died from this cause, there has been no pine or spruce timber killed by insects so far as I have observed within the last three years. ${ }^{2} \quad$ Therefore the accumulated evidence seems to warrant the conclusion that, iust as the destructive pine bark beetle was the primary cause of the commencement of the trouble, so was its universal disappearance the cause of the ending of the trouble.

RAPID DECAY OF DEAD TIMBER IN ONE SECTION OF THE SPRUCE AREA.

In the latter part of March, 1891, I was conducting some investigations in the spruce forests near Davis, Tucker county, where I had been informed that the dead timber deteroriated very rapidly and became worthless within three or four years after. It was reported by some of the timber operator's here that in cutting the dead trees they often found them sound at the base, while other portions of the trees were in an advanced stage of decay; also that the reverse is often found, decayed at

1. Up to the date of publication not a living specimen has been found.

2. Up to the date of publication, no dying spruce has been seen or reported. 
the base and the remainder sound; or in other cases logs are cut out of dead trees that are sound $\varepsilon_{.} t$ both ends and decayed in the middle. It had been observed by the operators that deadened trees and those killed by fire, as well as many that had died during the epidemic of 1883 to 1886 , remained sound for many years, but that the majority of those which had died during recent years were the ones that were the worst affected by decay.

A number of logs taken from dead trees were sawen into lumber at the Blackwater Lumber Co.'s mill at Davis, in order to show me the character of the trouble. Part of these logs were as sound and good for lumber as if they had been cut from living trees, while in other portions, the sap and heartwood were in an advanced stage of decay, thus rendering the entire log worthless for lumber. While I was talking to the superintendeut and watching the operation of the mill, I observed that a log from a living tree was also affected by a kind of dry rot throughout the heartwood in one section of the $\log$, the decayed portion being surrounaed by a thin rim of living sapwood. This gave me a clue to the cause of at least one character of the trouble, but there appeared to be at least two distinct kinds of decay, one developing in the sapwood and extending into the heartwood; the other developing in the heartwood of living trees and not affecting the living sapwood, I therefore continued the investigation to determine, if possible, the prime cause and the extent and distribution of each. I soon found some dead trees that showed evidence of having died within the past two years, and instead of the usual characteristic work of the common spruce bark beetle in the bark, I found the work of bark and sapwood borers (round and flat-headed grubs.) The character of work of these borers, the absence of bark beetles. and the recent death of the trees, indicated at once that they were serious enemies both of the living trees and the wood of the dead ones. Further search revealed the fact that the timber in this section of the forest had not, as a rule, died in large patches of one to one hundred or more acres, as was 
observed in the Cheat region in 1890 , but that the dead trees were scattered through the forest among the healthy ones. and that they showed evidences of having died at different times during a long series of years.

One typical example of a perfect spruce tree was found which was two feet in diameter, and not less than 100 feet tall that had recently died. Upon examination it was found to be infested by a great number of the round-headed bark and sapwood borers which had entered the sapwood, one-half to three inches, to form pupa cases in which to change to the adult, and that some of them had already changed to the adult and emerged, leaving holes in the bark and wood. It was also observed that the sapwood had commenced to decay, which was a most unnsual occurrence in a spruce tree that had not been dead one year. It was found, however, that the work of the insect offered the most favorable conditions for the premature decay of the sapwood, especially in the peculiarly formed pupa cases, and the holes left in the bark by the emerging adult. These openings allow moisture and water to enter the empty pupa cases, thus offering the most favorable conditions for the entrance and rapid-deveiopment of the fungus that causes the decay of the wood. This explains at least one of the causes of the rapid decay of the dead trees in this section. The abundance of the insects in certain parts of the tree, and their absence in other parts, resulted in the unequal distribution of the decayed condition.

It was also evident that many of the living trees in this section were suffering from the diseased and partly decayed condition of the heartwood, as observed in the logs at the mill. Hence, the spores of the fungus must be abundant in the air and readily find their way into the openings, in the wood and bark, made by the insect. As to the cause of the trees dying in this section, it is in my opinion owing to the natural deterioration of some of the trees, aided by disease and insects, since they do not die in groups as they do when killed by insects, but as a rule, are promiscuously scattered through the forest. 
It is evident, however that the destructive sapwood borer exerts a marked influence in hastening the death of the trees, and it is not improbable that in some cases they may cause, on their own account, the death of trees which otherwise would survive.

WOODPECKERS ARE THE PRINCIPAL ENEMY OF THE DESTRUCTIVE SAPWOOD BORER.

The trees that have been infested by the destructive sapwood borer are readily distinguished from those that are not, by the numerous holes in the bark and wood, made by the birds searching for the grubs. The punctures by the birds also offer additional opportunity for the lodgment and entrance of the fungus germs. The pres. ence of the woodpecker's work, especially if common, is therefore a fairly reliable indication that such trees are more or less decayed, which evidence of unsound trees may be utilized to some advantage by timbermen. Another remarkable and interesting fact observed with reference to the work and presence of this insect, is the absence of the bark beetle in the bark of the tree infested by the bark and sapwood borer, showing that the conditions that are favorable for the attack of the bark beetle, are not favorable for the attack of the borer, and vice versa. When both were found infesting the same tree, which was rare, the bark beetles occupied one side of the trunk, while the borer occupied the other.

It would therefore appear that the destructive sapwood borer is capable of doing much mischief, both in contributing to the death of the trees and the rapid decay of the wood, and that in this section, at least, it is the cause of serious loss of valuable timber.

\section{PRESENT CONDITIUN AS TO INSECT ENEMIES.}

Recent observations lead us to the conclusion that the living spruce throughout the area is at the present time in a healthier condition and freer from damage by inseets than it has been for many years. This healthy condition of the timber is due to the recent disippearance of its greatest insect enemy -the destructive pine bark-beetle-and to the extensive and continued cutting of the timber which furnishes, in the felled 
trees, logs, tops and stumps, more inviting breeding places for its next greatest enemy-the spruce bark-beetle. Thus it would appear that the present great destruction of timber by lumbermen is at least having one good effect-that of attracting to the various fields of operation, the surplus of all those insects which may breed in dying, or storm-felled trees in the virgin area, and in this manner the living trees are protected from their attack. A general discontinuance of operations in the spruce area would probably be followed by fatal consequences to the living trees, on account of the swarms of the spruce bark beetle and their allies, which would doubtless invade the living timber when they failed to find a supply of recently felled trees and tops in which to breed.

The present serious injuries to the spruce by insects is confined to the timber injured by fire, recently felled, or cut into saw logs. If such timber is allowed to remain standing, lying on the ground, or in skidways, with the bark on, for a few weeks, between the first of April and the middle of September, it will be attacked by wood boring species which may materially depreciate its value for lumber. If allowed to remain thus through the summer, it may be rendered almost worthless by the wood boring insects for anything but pulpwond.

The living timber is not, it must be remembered, entirely safe from another destructive invasion of insects since a series of favorable conditions, as of succesive warm winters, excessive and long continued drouths, unusually severe hail and wind storms, together with a diminution of the parasites and other natural enemies of the destructive insects, may be the means of starting another serious trouble like that recently experienced in the pine forests of this and adjoining States. Thus, the importance and necessity of owners of spruce forests keeping a vigilant watch for all indications of trouble, and when anything of the nature we have mentioned is observed, this department of the Experiment Station should be informed about it, without delay, in order that we may extend such advice or assistance towards preventing the loss of timber as may be in our power. 
THE PRINCIPAL INSECT ENEMIES OF THE SPRUCE IN WEST VIRGINIA.

Almost every part of a spruce tree from the roots to the terminal twigs, bnds, leaves, and cones, may be infested by one or more insect enemies, some attacking the vital parts of the living trees, and thereby cause rapid death, while others attack only those which are sickly, dying or dead, and thus hasten the death of the sickly and contribute to the destruction of the wood of the dead ones. Thus it is found that some may be classed as primary enemies, while others are secondary: some are destructive, while others are simply injurious.

During the investigations, I found that among the large number of insect enemies of the spruce, observed and studied, only a few are of special economic interest as primarily detrimental or destructive in their relation to the spruce timber resources of the State. The vast number of individuals of some of these species, however, and their power of destruction, more than makes up for what is lacking in numbers of species, and the enormous loss they have already inflicted and are capable of causing in the future, demands that they should receive especial attention.

The principal insect enemies of the spruce, so far as 1 have observed in this State, may be best discussed under two separate heads, viz: bark miners and wood miners.

\section{BARK MINERS.}

The bark miners include many species which mine through the outer and inuer bark on every part of the tree, some preferring to infest that on some particular part, while others make no choice; some attack the healthy bark on living trees, while others can only live in the bark after active growth has been checked by some other callse; some mine beneath the bark in the adult stage, for the purpose of excavating galleries in which to deposit their eggs, while the adults of other species simply deposit their eggs in the crevices of the outer bark and the young enter and burrow beneath and through the inner bark or outer surface of the wood. 
As is well known, the newly forming or growing tissue and liquids, between the inner bark and outer wood, the cambium, is the most vital part of the iving tree. Therefore, it is plain that any injury like that resulting from insects mining beneath the bark, must result in an abnormal condition, weakened vitality or death of the parts so infested, and that if the attack is sufficient on certain parts of the tree to overcome the natural resistance and efforts of the injured tree to heal the wounds, the weakened vitality of the entire tree must follow. When this occurs, its recovery is prevented by numerous other bark and wood infesting insects, which on this account, are attracted to it. Thus, we find that the insect which

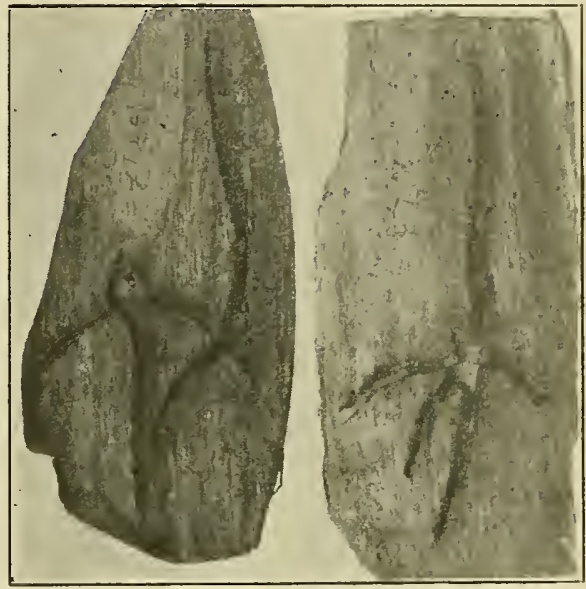

Fig. XXII.-Nuptial chambers of Tomicus pini in black spruce.

is capable of mining beneath the healthy bark of a living iree, is the one to be especially dreaded, since it mnst be the leader in the attack and must overcome a certain degree of the resisting forces, before its numerous allies or dependents can render assistance in the destruction of a single tree or a forest.

THE DESTRUCTIVE PINF BARK BEETLE. ${ }^{1}$

Strange as it may seem, this is the only one of the many species of bark borers observed in the spruce that was found making a primary attack on the healthy bark of living trees in such a manner as to cause their death. Therefore, it is beyond a doubt, entitled to highest rank among the insect enemies of the spruce, as well as the pine. The hundreds of dying and dead, as well

1 Dendroctonus frontalis, Zimm. 
as a large number of living sprace trees infested by this insect
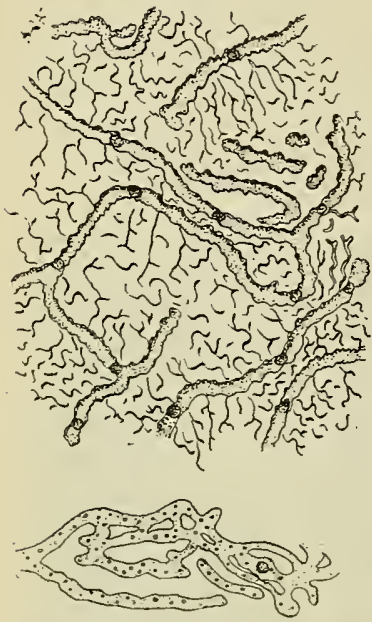

Fig. XXIII-Galleries of Denaroctonus frontalis in spruce. which were examined during a tour of investigation through the spruce forests in 1892, left no donbt whatever of its power of entering and mining through the healthy bark of vigorous, living trees, or of its being the primary cause of the death of the timber. I also found it attacking and killing Norway spruce in Morgantown, and found it in abundance in a dying spruce (See Fig. XXIII) in Washington, D. C., in Uct., 1892. A full description and illustration of this remarkable insect and its work, and a detailed account of its life history and habits will be found in another part of this report, under "Insect Enemies of the Pine."

THE DESTRUCTIVE SPRUCE BARK BEETLE. ${ }^{1}$

This is a small black beetle, .0S of an inch long and .1 of an inch broad. It is easily distinguished from all other spruce bark beetles of similar size and form by the fact that each of its compound eyes is divided by a smooth narrow space. It passes the winter in all stages within the bark of spruce stumps, logs, and tops of trees cut the previous winter or summer; also in the bark on all parts of such standing trees as may have died during the previous spring or summer. The adults emerge in May and June, and are attracted to the stumps, trunks and tops of recently felled trees and such trees as are weakened in vitality from the attack of insects like that of the destructive pine bark beetle, diseasés or any other cause. They then commence to excavate their entrance galleries through the outer bark, their presence being indicated by the fine brownish borings in the crevices of the bark. This entrance gallery is extended to the outer surface of the inner soft 


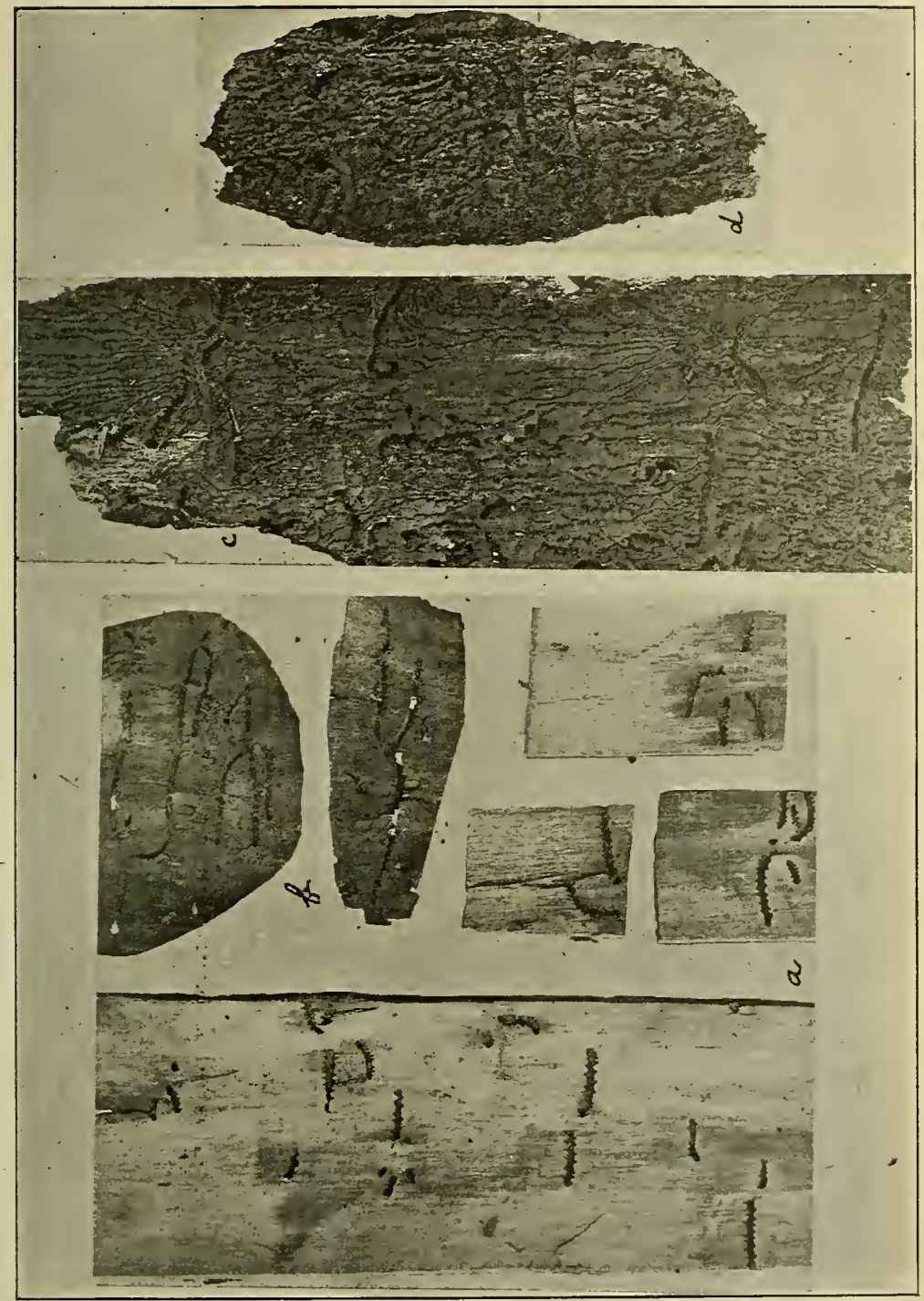

Fig. XIV.-Galleries of Polygraphus rufipennis, showing different stages, from the beginning of the egg gallery at $a$ to the honey combed inner and outer bark at $d$, in black spruce. 
bark, where a broad cavity is excavated which is utilized as a nuptial chamber. In the meantime, the female, which appears to do the greater part of the first excavating, is joined by a male which stations himself in the entrance gallery to keep out enemies and objectionable visitors, and to render assistance in expelling the borings. The female then excavates a gallery from one edge of the nuptial chamber through the inner bark to the wood, thence through the inner layer of bark, usually at right angles to the bark fibers, for a distance of one or two inches. Along the sides of this so-called brood or egg-gallery, she deposits her minute, pearly-white eggs in a succession of small notches. By the time the first female has her egg gallery tairly started, one to three other females are admitted, and each excavates a similar egg gallery in different directions from the nuptial chamber. Before all of the galleries are finished, the first egg commences to hatch into minute white grubs, which burrow through the inner bark, on which they feed. By the time all of the eggs have hatched, the surrounding bark is filled with these grubs of various ages and sizes, and soon, all

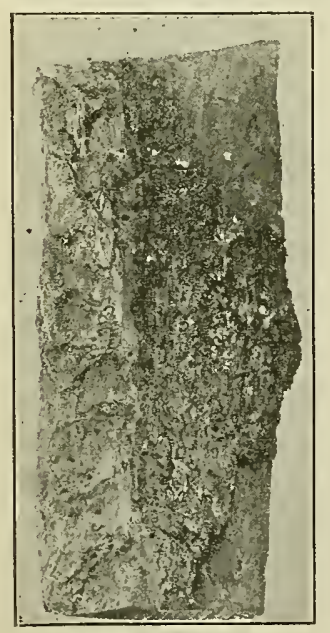

Fig. XXV.-Chip from Black Spruce log. showing destruction of bark and exit holes made by Polygraphus rufipennis. of the bark from the inner to the outer layer, for a radius of two to four inches, is completely perforated with their irregular burrows. In the meantime, the male guards the entrance and the females either rest in the nuptial chamber or egg galleries, or emerge to enter the bark in another place to start a new brood. When the grubs and larvae have attained their full growth, they excavate : broader cavity at the end of their burrow or mine, in which they change to the pupae stage, thence to the adult and either emerge from the bark and start 'a second brood, or remain there until the following spring. Probably two or three broods may 
occur in one season, commencing with the first eggs deposited in the spring, but my observations lead me to believe that owing to the shortness of the season at the high elevations occupied by the spruce in this State there is generally but one brood.

Uther Trees infested by it. Besides the black spruce, it has been recorded from the larch in Michigan ${ }^{1}$ and I have found it in the larch in West Virginia. I also found a single example excavating an entrance gallery in the bark of scrub pine on the mountain near Morgantown. Dr. Packard² mentions that this species infested pitch pine, but he undoubtedly referred to a species of Dendroctonus, certainly not to this species, although he published a good illustration of the beetle from a drawing by Dr. Bland and Miss Sullivan.

Distribution. The species is evidently widely distributed over North America, and doubtless occurs where spruce is indigenous. It has been recorded from New Hampshire to Alaska and Georgia. In West Virginia it appears to be confined to the Canadian Life Zone and the spruce area, since I have never met with it in the cultivated spruces in any of the other life zones.

Previous Knowledge of its Habits. It appears that very little has been previously recorded with reference to the life history and habits of this insect, except such reference as the writer has made to it in the publications referred to on another page. The insect referred to by Dr. Packard, in the 5th Report of the U. S. Entomological Commission, under the name "Xyloterus bivittatus," as the beetle most concerned in the ravages of the spruce forests of New England, may possibly have been this species, since his description of the habits and galleries could not have been the work of Xyloterus bivittatus, which is not a bark miner, as will be shown further on.

The Abundance of the Insect and Its Economic Relations to 
the Spruce. The spruce bark beetle is by far the most abundant of any of the species of the family to which it belongs ihroughout the spruce region in this State. It appears in enormous numbers in all sections in which timber cutting operations are carried on. As previously stated, its occurrence in such vast numbers, together with other evidence obtained in 1890 , with reference to its habits, seemed to warrant the conclusion that it was the species of all others which was to blame for the great destruction of spruce timber in 1883 to 1885 . While we have no additional evidence that this was so, it is evident from what has been determined of the habits of the species, that with a combination of favorable conditions, it may have been one of the prime causes, if not the prime cause, of the trouble. Its habits of gradually entering the inner bark, first by excavating the nuptial chamber in the outer layer of the inner bark, and then entering obliquely to the inner layer and extending the preliminary gallery across the bark fibers, indicates clearly that it has acquired this peculiar habit of attack through efforts to overcome the resistance met with in the bark of living trees, and that should it attack such trees in sufficient numbers, it would easily accomplish this end. The constant and abundant supply of stumps and tops in the extensive cuttings of spruce since 1885 , however, offered every desirable condition for it to breed to its utmost limit without the necessity of resorting to living irees, and as long as active timber operations are continued in the spruce, there is little danger of an invasion from this beetle. Should, however, the destructive pine bark beetle, or an insect with like habits again invade the spruce, this spruce bark beetle would prove its most powerful ally in the destruction of the timber.

Methods of Combatting this Enemy and Preventing Loss from Possible Future Depredations. As already stated, the present extensive cutting of timber is an effectual preventative against an invasion by this insect, but if in the future it should, from a series of favorable conditions, attack the living timber, serious loss can be prevented, and the trouble abated, if not checked, 
by cutting the dead and dying, as well as the living timber in the infested area, and converting it into pulp wood and saw logs as soon as possible after the trouble commences. This would leave a supply of lows and stumps to attract them away from the living timber.

Natural Enemies. As was determined in 1890 and mentioned in Bulletin 17, this beetle has numerous insect enemies, which, as was then predicted, are preventing its increase beyond a normal limit, and the same conditions which favor the breeding of the beetle, favor the breeding and multiplication of its insect and other enemies.

The Imported Enemy of Bark Beetles. Large numbers of the European bark beetle destroyer were placed, under the most favorable conditions, in different sections of the spruce forests, and while very few, if any, have been seen since, there is no reason why they should not bezome established and multiply where there is such an abundance of its natural prey in this common bark beetle.

\section{LE CONTE'S SPRUCE BARK BEETLE. ${ }^{1}$}

This bark beetle is about the same length as the destructive spruce bark beetle, but is easily distinguished from this species by its slender form, rust red color, and the long slender hairs with which its body is thinly clothed. Its habits are quite similar to that of the former species, with which it is usually associated; but does not appear capable of attacking and excavating its egg galleries in living, sappy bark. I have, however, found it mining in the bark of logs which had only been felled a short time, but never in the healthy bark of living trees. In 1890, I found it to be quite as common as the former species, as many as twenty-five examples being counted in one square inch of bark, and it was at first thought to be quite as much to blame for the trouble then under investigation. Subsequent observations indicate that while it might be a powerful ally to the destructive species, it would be dependent upon previous injuries and weakened vitality of the trees to enable it to gain 
entrance to the vital parts of the bark. Between 1891 and 1894 , this beetle became less abundant and in some sections of the forest was quite rare, but during the past year $I$ found it to be again quite common.

So far as I have observed it confines itself entirely to the spruce.

Very little appear's to have been published with reference to the life history and distribution of the species, except that recorded by Le Conte who described it from specimens collected in the mountains of Pennsylvania, and later, he recorded it from the District of Columbia.

\section{THE COSMOPOLITAN SPRUCE BARK BEETLE. ${ }^{1}$}

This bark beetle is of especial interest, since it has been determined that the examples collected in this country are identical with those from Europe where it is widely distributed and a common enemy of the Norway spruce. It was described as early as 1837 by Ratzeburg in his great German work on forest insects.

It was possibly introduced into America with young Norway spruce trees imported from Europe at a very early date, since it is now widely distributed over North America, it having been recorded by Le Conte in IS6S from Alaska and Hudson Bay to Virginia. It is considerably larger than its near relation, Le Conte's spruce bark beetle, and darker in color, yet of similar form and general appearance. Its habits, while similar to those of the other spruce bark beetles, so far as mining in the bark and development of broods is concerned, differs in its preference for the bark at the base of the tree or stumps, and even that of the roots of the latter, in which I have frequently found it in abundance, both in the exposed roots, considerable distance away from the base, and in those several inches below the surface of the ground. This habit of attack, together with the fact that I bave frequently found it in living bark on stumps and logs of recently felled trees, as well as in that of recently 
injured standing ones, is good evidence that under favorable conditions it may prove to be a destructive species.

It is widely distributed in the State, and apparently occurs wherever the native or cultivated spruces grow in sufficient quantities to attract it. I have found it exceedingly common in felled and injured Norway spruces in Morgantown, and next to the two preceding species is the commonest spruce bark beetle met with in the spruce forests of thr State.

In September, 1892, I found it in abundance in the bark of spruce logs and stumps in the Lauterbrunnen Valley, in the Swiss Alps, and observed that its habits there were the same as in this country.

\section{EICHHOFF'S 5-TOOTHED PINE BARK BEETLE. ${ }^{1}$}

This bark beetle which is distinguished by five teeth near the tip of each wing, or declivity, as shown in the illustration, (see pine insects,) is an exceedingly common insect in the pine. I do not know that it has been mentioned by previous writers as infesting the spruce, but I found it, in August, 1890, and July, 1892, in the black spruce of Randolph county, and in July, 1892, in Norway spruce at Morgantown. It was not common in the spruce in 1890 , but in 1892 . I found it quite common in living trees injured by the destructive pine bark beetle, and from what I have observed of its habits in the pine, it is doubtless capable of attacking healthy trees, and if in sufficient numbers, could easily cause their death. At present, however, it is attracted to tops, logs, and stumps of felled trees, and as long as active timber cutting is continued, there is little danger of its attacking the healthy timber. For further information on this species, see pine report.

\section{SAY'S PINH' BARK BEETLE.?}

This bark beetle, which was described by Thomas Say as early as 1827 , is distinguished by the presence of but four teeth on each side of the declivity or tip of the wing covers. (See 
illustration.) It is exceedingly common in the bark of white pine, and attacks all of the other kinds of pine in the State. I have also found it in both the Norway and black spruce of the State, but not so common as in the pine. In May and June, 1897, I found it quite common excavating egg galleries in the living bark of black spruce in the pine swamps near Cramesville, Preston county, and my observations of its habits led me to conclude that under favorable conditions, it might prove a destructive enemy of the spruce.

FLAT-HEADED SPRUCE BAKK MINERS.

The so-called "flat-headed" bark miners are white, footless grubs, with the front seginents of the body broad and flat, the

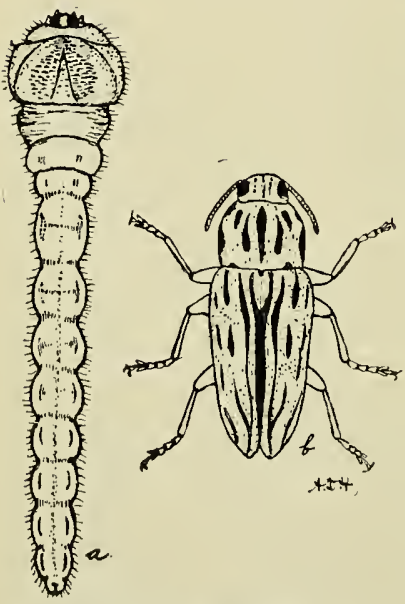

Fig. XXVI.-Flat-headed Wood Miner, $a$ larva, $b$ adult, (the latter after Marx.) first segment resembling the head. 'The real head is comparatively small, but armed with stout, bitiug mandibles, by means of which they burrow in the bark and wood. The portion of the body back of the first two or three segments is usually quite slender.

These grubs hatch from eqgs deposited in the outer and inner bark by beetles, like Fig. XXVI. 'They burrow through the inner layers of bark and outer layers of the wood, until they attain their full growth, when they excavate cavities either in the outer bark or in the wood in which they transform to adults.

I have found several species on or in the spruce, and have observed numerous forms and sizes of the grubs in the bark of spruce trees and twigs which could not be identified. 'There are, doubtless, quite a number of species of this class of borers which infest the spruce. I have found some of these larvae in the living bark of standing and felled trees, and have other evidence which leads me to believe that they might, under favor- 
able conditions, prove quite serious enemies of the living timber. They are at least among the principal allies of the destructive bark beetles in attacking trees in any way weakened in vitality. One species of this class of borers ${ }^{1}$ has, as I have observed, caused the death of a great number of hemlock trees, while another spezies ${ }^{2}$ is killing the oak in different sectious of the State; others attack and kill the broad-toothed aspen, the common dogwood and willow; while the common, flat-headed apple tree borer is destructive to fruil trees of various kinds. They are, therefore, among the most destructive insect enemies of trees.

\section{ROUND-HEADED SPRUCE BARK MINERS.}

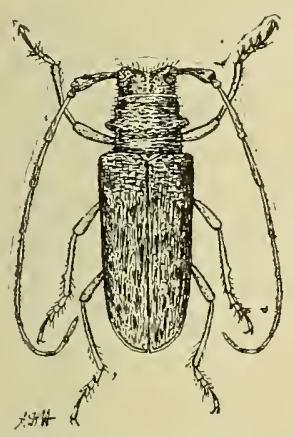
Fig. XXVII.-Round-head-through the inner d wood miner: ałult of the "Sawyer." or Longicorn beelles, and their habits of mining bark and wood is

The so-called round headed bark miners, (See Fig. XXVIII,) as the name indicates, 'are distinguished from the flat headed kind by the round or cylindrical form of the front segments of the body which is also broader than other sigments. They are the young of long-horned

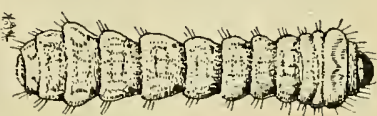

Fig. XXVIII.--Round headed wood miners; the Sawyer larva of Fig. XXVII.

the same as that of the flat-headed miners. As a rule, however, this class of round-headed borers mine in the bark until they have attained sufficient size and strength to enter the wood, when they are classed with the wood miners, but some species live entirely in the inner bark and change to the adult at the end of their burrows, either in the inner or outer bark.

\section{WOOD MINERS.}

The wood mining insects which infest different parts of the spruce trees and saw $\log \mathrm{s}$, consist of adult beetles called tim- 
ber beetles, which excavate galleries in the wood for the purpose of depositing their eggs and rearing their young; also wood boring grubs which hatch from cggs deposited in the outer bark by allult beetles and wood wasps. As a rule, these wood borers contribute very little towards the unhealthy condition or death of the trees infested by them, but are exceedingly destructive or detrimental to the wood of living, dying, or dead trees and saw logs and the loss of timber resulting from their depredations is far greater than is generally supposed.

TIMBER, OR AMBROSIA BEETLES.

Among the wood miners, some of the inost destructive kinds belong to an interesting class called timber beetles, or ambrosia

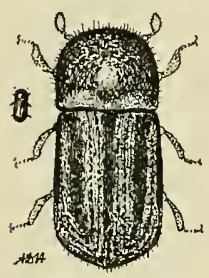

Fig. XXIX.-Timber or ambrosia beetle. The Spruce Timber Beetle. ( Yyl. oterus lineatus, Ratz.) beetles. These belong to the same family as the bark beetles, but instead of mining beneath the bark and gnawing the outer surface of the wood, they burrow directly through the bark into the sapwood where they excavate their branching egg or brood galleries. One species of this class of miners is exceedingly common in the sapwood of spruce trees and logs, which deserves special mention.

This wond miner is distinguished from all other species of similar form and habits, wheih infest the spruce, by its striped wing covers. The adult is .13 inches long, and .06 inch wide, the male with a narrow concave head and the female with a large head, which is convex in front. The eyes are double, as in the destructive spruce bark beetle. It passes the winter in all stages within the brood chambers, and the adults emerge in the spring and fly to the trunks and stumps of recently felled trees, or those seriously in-

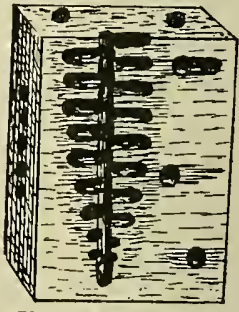

Fig. XXX, - Work of Ambrosia Beetle (Xyloterus lineatus, Ratz). jured by insects or other causes. They bore directly through 
the bark and into the sapwood. The entrance is made by a single female, attended by a male. After she has penetrated into the wood, one or more females are admitted, and each excavates a gallery, branching from the first, while the male remains at the entrance to assist in expelling the borings and to guard against the entrance of their insect enemies. After each female has extended her gallery a short distance into the wood, small cavities are excavated in the sides of the gallery walls. An egg is placed in each of these, and the mouth of the cavity is closed with fine wood borings and cemented with sap and excrement. These egg cavities are placed at regular intervals as the gallery is extended, until each female has deposited from ten to twenty or more eggs. Before the first eggs hatch, a pecnliar kind of fungus, the germs or spores of which are evidently carried from the old brood galleries, gathers on the bodies of the parent beetle, and commences to develop on the walls of the galleries and in the mass of borings at the mouth of the egg cavities, forming a granulated, cheesy mass, called ambrosia. ${ }^{1}$

The eggs hatch into minute, white grubs, which commence to feed on the ambrosia at the mouth of the egg cavity, and as they grow, they enlarge the cavity to accomodate the increasing size of their bodies. It appears that the young grubs are provided with a continuous supply of the ambrosial food by the parent beetle as she moves back and forth in the gallery. The walls of the gallery becomes thickly coated with the fungus, which without the vigilant care of the mother beetle, would completely fill the galleries and smother the occupants. When the grubs attain their full size, they change to pupa and adults, in the cavities or cradles, which are just large enough to comfortably accommodate their bodies. After changing to the adult, they come out into the main gallery and either excavate other branching galleries, or emerge to start new ones on nearby trees. Possibly two or three broods develop in a single season from the first set of eggs, the later bronds remaining in the galleries over winter.

1 For further and more detailed information see the excellent paper on the subject by the late H. G. Hubbard, Year Book U. S. Dep. Agric., 1896, pp. 421-430. 
The presence of this insect may be easily detected by the fine white borings in the loose bark of the standing trees, or beneath the logs on trunks of felled ones. Often the ground under the logs in a skidway will be literally covered with these borings.

If saw logs are left in the woods or in the skidway for a few weeks between the first of May and the middle of Octuber they are often seliously damaged by this beetle which is exceedingly common throughout the spruce forest. In fact, the sapwood is often literally ruined, except for low grade lumber and pulp wood, by the numerous black sapwood pin holes and sap stains resulting from its attack.

It also attacks the hemlock and pine, especially the white pine, but is more common in the spruce. It is widely diatributed over: North America, and like the European spruce bark beetle, is common in the spruce forests throughout Europe.

Dr. Packard referred to a bark beetle under the name of this species as the most destructive pest of the spruce, the beetle most concerned in the ravages of spruce forests in Northern New England from 1878 to 1881.1 But since it is not possible for this wood infesting ambrosia feeder to change its habits to that of a bark beetle, evidently there was some mistake in the identification of the species, or else the work of a bark beetle was credited to this timber beetle, just as Say credited the work of the bark beetle Tomicus coelatus to the timber beetle Xyleborus xylographus, owing doubtless, to a wrong reference in the original collecting notes. This is an error which is very easy to make when so many species of bark and timber beetles infest the same tree; or when a timber beetle is found excavating an entrance through the bark to the wood.

\section{ROUND-HEADED WOOD MINERS.}

The character of this class of enemies has been already described on another page, under the head of "Round-headed Bark Miners." In fact. nearly all of the round-headed, as well as the flat-headed wood miners live for a time in the bark, some drawing by Gissler resembles somewhat Derdnoctonus simplex.-A. D. H.) 
of them entering the wood only when they have attained their full growth, while other's enter as soon as they have attained sufficient size and strength to do so.

Large numbers of apparently different kinds of round-headed wood mining larvae, were found in the spruce, but only a few species could be identified, owing to the fact that the adults could not be bred.

The Destructive Spruce Wood Miner1 deserved special attention, since it is the one which contributes to the rapid decay of the wood of standing trees, and since the young grub has been found mining in the living bark on living trees, it might easily contribute to the death of some trees. The trouble caused by this insect is described at length in another part of this report. It is therefore only necessary to state that it is a common insect throughout the spruce area, to which it is probably confined in its distribution in West Virginia.

The eggs are deposited early in the spring, by a slender, lightbrow $n$ beetle in the outer bark on the trunk of large trees, usually at points from near the base to the first branches. These eggs hatch into minute, white worms, which mine through the inner bark and outer surface of the wood, until they are nearly full grown, when they enter the sapwood in which they mine until they have attained their full size, which is from $7 \mathrm{twelfths}$ to $8 \mathrm{twelfths}$ of an inch in length and an average width of about $3 \mathrm{twelfths}$ inches. The three frout segments are slightly broader than the others, and each is provided on the underside with a pair of small legs. Each example of the matured larvae excavates a cavity in the wood, and also an exit gallery to the outer bark. The mouth of the inner cavity or pupa case is then packed with borings and the larva transforms to the pupa and adult within the cavity, after which the beetle finds its way out through the exit prepared by the larva.

INJURY TO TERMINAL BRANCHES BY THE WHITE PINE WFEVIL, 2

This insect which has been mentioned by other writers as 
especially destructive to the white pine is a snout beetle, somewhat related to the plum curculio and certain grain weevils, but with totally different habits. It is a chestnut brown beetle about a quarter of an inch long, with two dots on the upper portion of the front part of the body, (thorax), and with two irregular spots on the inner edges of the wing covers. It passes the winter in the larveal stage in the outer wood or in the twigs. The adult comes out in May to deposit its eggs in the terminal or main shoots of young or medium sized trees; also in the bark of logs or injured and felled trees. These eggs hatch into white footless grubs which mine in the bark at first, then in the wood or bark of the twigs until full grown, when each grub excavates a cavity in the outer surface of the wood. These cavities are just large en ough to accomodate the body of the grub, and are lined and covered over with fine wood fibers, thus forming a snug cocoon in which it transforms to the adult.

The injury to large trees and logs resulting from the work of this bark and wood miner is not usually of a serious character, but when it attacks the main or central shoot of a young tree, the injured part dies and this usually results in a deformed or worthless tree.

It is a widely dirtributed insect in North America and I have found it common in the pine and spruce of West Virginia. In 1891 specimens were received from Mr. Hu Maxwell, of St. George, Tucker county. in branches from Norway spruce shade trees, to which it had done considerable damage.

\section{INJURY TO TWIGS BY THE SPRUCE GALL LOUSE, ${ }^{1}$}

This is a minute, almost microseopic lonse, which infests the tender twigs of the native and cultivated spruce, causing swellings and a thick cluster of needles or leaves on the twigs, and when common on a young tree, many of the twigs so affected die, and the tree is stunted in its growth. This is a common trouble affecting the spruce in different sections of the State, and was reported as especially common and destructive to 


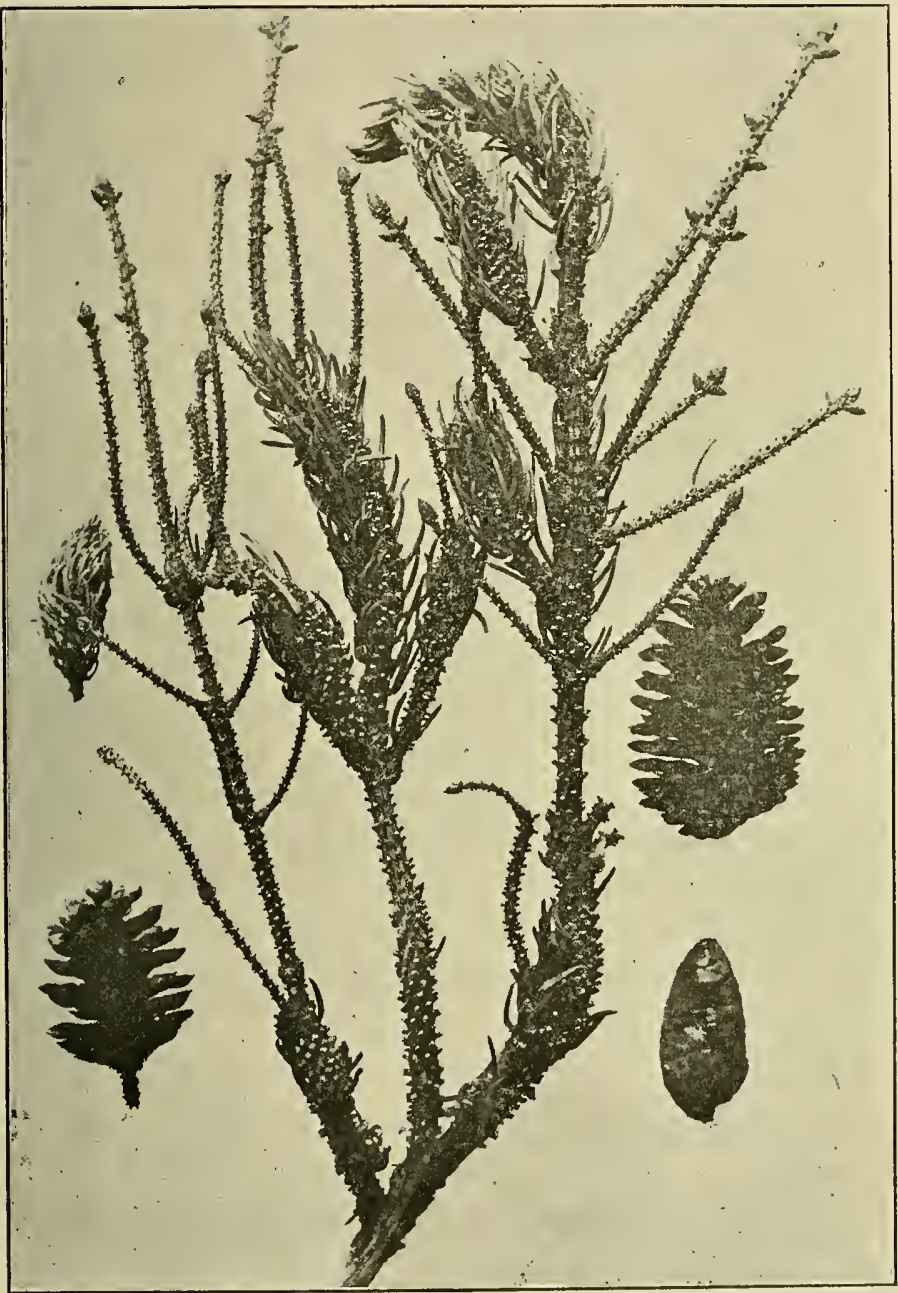

Fig. XXXI,-Galls and deformed twigs of the spruce gall louse on black spruce: also black spruce cones.

large as well as small trees near Cranesville, Preston county, in 1894. I have seen it in different sections of the spruce forest from Tucker to Pocahontas counties, and also on Norway spruce in Morgantown. 
This trouble appears to be widely distributed over the country, and has received especial attention from Professor C. H. Fernald of the Massachusetts Agricultural College in a recent paper.

THE PRINCIPAL INSECT FRIENDS OF THE SPRUCE, OR ENEMIES OF THE INSECT ENEMIES.

The insects which are friendly or beneficial in their relation to the spruce are those which prey upon the enemies and thus prevent their excessive increase, and reduce the amount of injury to the tree or its products.

There are two classes of these beneficial insects, separated according to their habits. One class which includes beetles and their larvae attack and devour the adult, young, and eggs of the injurious insects. While the other class which includes the young of four-winged bees and wasps and two-winged flies, attach themselves to the young of the injurious species, or enter their bodies to absorb the liquids, thus causing the gradual death of their victim.

The list shows that considerably more beneficial than injurious species were taken from the spruce, but as a rule, the total number of individuals of the injurious species is far greater than that of their predatory and parasitic enemies, and were it not for this check, they would multiply to excessive and devastating numbers.

\section{PREDACEOUS BEETLES AND THEIR LARVAE.-THE CLERIDS.}

The Clerids are perhaps entitled to occupy first rank among the insects which prey npon the principal insect enemies of the spruce. They are considerably larger than the insects upon which they feed, and resemble the European bark beetle destroyer (illustrated in the pine report) both in appearance and general habits.

The American Bark Beetle. Destroyer ${ }^{1}$ is nearest related to the European species, and is often quite common on the bark of spruce trees infested with bark beetles. It is easily distinguished from the imported spesies by its red head and some- 
what paler color, although the marking on the wing covers and the size is the same in both species. It passes the winter in all stages from larva to adult, in the bark in which it is bred, the latter sometimes in the loose bark and moss at the base of the tree. The adults appear in the spring, soon after the bark beetles commence to emerge from their winter quarters and fly to the trees, logs, or tops which are infested with bark beetles. There they station themselves beneath loose flakes of bark, awaiting an opportunity to pounce upon any bark beetle that comes near. They also move rapidly about over the bark in search of the prey, or the entrances to the bark beetle galleries in which the females deposit their eggs. The eggs soon hatch into minute active worms, which find their way into the egg and brood galleries of the bark heetles, where they feast upon the eggs and young found there until they have attained their full growth, when they leave the inner bark and excavate cavities in the outer corky bark in which they change to pupae and adults. The larvae resemble that of the European Clerid, illustrated on another page. Indeed, it is scarcely possible to distinguish one from the other.

This Clerid attacks and feeds upon all kinds of bark beetles which infest the spruce and pine and has also been found attacking bark beetles in deciduous trees. It is widely distributed over the State and doubtless has a wide range throughout North America. It is a common insect wherever the pines and spruces grow in the State, and doubtless exerts a considerable influence in preventing the undue increase and devastations of pine and spruce bark beetles. Unfortunately, it also has its enemies to contend with, since it has at least two parasites, one of which I have reared from the larva and the other from the adult. The first, which is an internal Braconid parasite, apparently attacks the full grown larva, when it enters the outer bark to pupate. This parasite is in turn, apparently, attacked by another parasite, which I have bred in large numbers from the larvae of the Clerid. The parasite of the adult is a twowiuged fly, resembling ạ smạll house fly, whịch dẹposits an egra 
on the living adult, and when the egg hatches, the maggot enters the abdomen of the beetle, where it absorbs its nutriment from the liquids of its host until it is full grown, when it emerges from its victim and changes to the pupa and adult probably in the ground. Remarkable as it may seem, the beetle remains alive and active until after the parasite larva leaves it, although the full grown maggot almost fills the abdominal cavity of its host. Just how common these enemies of the Clerid are, and to what extent they reduce its numbers, it is difficult to judge, but since I have only bred one example of the fly, and only one or two of the Braconid, and have bred probably one hundred examples of what is, evidently, a parasite of the Bracon larvae from two of the Clerid larvae, it would appear that these parasitic enemies of the Clerid cannot be very numerous.

This beneficial insect has another class of enemies in insectiverous birds, by which its numbers are greatly reduced, since they are exposed to attack while running about on the bark and are easily procured by woodpeckers from their pupa cases in the outer bark.

During the early investigations in the spruce and pine forests in 1892, this insect and other enemies of the bark beetle appeared to be rare, but in the fall of 1892 and the spring of $\mathbf{1 8 9 3 ,}$ they were abundant.

Two or three other species of Clerids, (see appendix, ) have been found with the spruce bark beetles, but since their general appearance and habits are similar to the one just mentioned, it is not necessary to discuss them further.

STAPHYLINID OR ROVE BEETLES AND THEIR LARVAE.

Numerous representatives of the rove beetle class or family of insects were found associated with the spruce bark beetles and their young, and since they are usually predatory in their habits, some of them doubtless feed on eggs and young of the insects with which they associate. They are small, slender beetles, with very short wing covers, and strong biting mandables; are exceedingly rapid in their movements, and are usu- 
ally seen with their tails, or rather their abdomens, erect, or turned forward, over their backs.

A small black species, (Homalota pontomaloto, Casy) was commonly met with in the galleries of the spruce bark beetles, in all sections of the spruce forest and in the Norway spruce near Morgontown, and while I have not observed it feeding, it doubtless attacks the eggs and young larva of the bark beetles, and if so, must destroy great numbers of them. Other species were also found in the galleries of the bark beetles, or associated with them in the bark, bit were not observed feeding. Indeed, all of these rove beetles are so wild that it is almost impossible to cbserve their feeding habits without disturbing them.

\section{HISTERID BEETLES.}

The Histerid beetles are easily distinguished from all other bark infesting species, by their jet-black, polished and shining wing covers, which do not extend to the tip of the abdomen. The other parts are also black and shining. Some species have short, flat bodies, while others are more elongated and cylindrical. The three species which were commonly met with in the egrg galleries of the spruce bark beetles were evidently there for the purpose of feeding on the adults, eggs, or young. I have frequently observed one species, (Hister cylindricus) feeding on adult bark beetles, and the others doubtless have simi lar habits. One quite small species, (Paromalus bistriatus, Er.,) was found to be very common in the bark of black spruce, with the bark beetles. The larvae of these beetles are slender, flattened, yellowish, shining worms, with curred spines on the last abdominal segment.

\section{NITULID BEETLES AND THEIR LARVAE.}

The Nitulid beetles also have shining wing covers, which are shorter than the abdomen, but instead of being uniform black, they are usually brownish and marked with yellow or whitish spots.

While some of the species of this family of insects feed upon 
and breed in fungi and lichens, several of the species are known to be predacenus. Of the four species found in spruce bark, two were with bark beetles and one, (Ips fasciatus, Oliv.) with its larvae, was with the spruce timber beetle.

\section{TENEBRIONID BEETLES.}

The Tenebrionids are elongated, slightly flattened, brown to black beetles, with wing covers extending to tip of abdomen. Some of this class of beetles feed on vegetable substances, such as dried seeds, grain, fungi, \&c., while others are known to feed on insects. Two species were found in spruce bark, associated with bark beetles, both the adult and larvae; one species (Hypophloeusparallelus, Melsh.) was very common in the mines of spruce bark beetles. It is also common in pine and $I$ have found it with a bark beetle in hickory bark.

While this beetle and its larvae doubtless feed on the larvae and possibly the adults of bark beetles, I have no evidence to indicate to what extent it does so, except the inference drawn from their common occurrence in the galleries of bark beetles.

PARASITIC INSECTS.-ICHNEUMONID PARASITES.

The adult Ichneumonid parasites are wasplike insects, usually with long stings, or ovipositors, which they insert in the bark and wood for the purpose of depositing eggs in or near their bark or wood mining victims. Several examples of one species of this class of beneficial insects ${ }^{1}$ were found emerging from the wood of a spruce tree, infested by one of the wood wasps, ${ }^{2}$ the larvae of which they had evidently destroyed. Another species ${ }^{3}$ was found with its ovipositor inserted in the wood of a spruce log. Numerous examples of both species were observed flying around logs and dead trees in the spruce forest during the last of August and first of September.

\section{BRACONID PARASITES.}

The Braconids are similar in general appearauce to the Ichneumonids but are usually much smaller and have shorter 
ovipositors. They are among the principal enemies of ti, e bark and wood mining insects, and are entitled to high rank ainong the friendly insects of the spruce. The eggs are deposited near or in their victims by means of their ovipusitors, which are inserted through the bark. As a rule the Braconid larva attaches itself to the side or back of a bark or wood mining larva, which is soon rendered inactive from the loss of life sustaining liquid or blood. It then ceases to feed and soon dies. The parasite maggot continues to feast on its dead victım, and in a few days attains its full growth. It then encases itself in a thin but tough cocoon, which completely fills the cavity previously occupied by its victim. In this cocoon it goes through its transformations, and when the adult is fully matured, it gnaws its way out through the bark.

\section{CHALCID PARASITES.}

The Chalcids which are also four-wingred insects and related to the wasps and bees, differ from the Ichneumonid and Braconids in having shorter and more compact bodies; also in the color, which is usually bright shining blue, green, bronze, or black, often with hyaline or metallic reflections. The wings, instead of having numerous veins as in the two former families, are veinless or have but few. They also show a marked difference in the antennae, which in the former families are long, slender, while in the Chalcids they are short, often club-like and elbowed. They are also distinguished by the form of the hind femur which is often very much thickened for leaping. The ovipositor of the female is usually concealed beneath the body and is much shorter than in most Ichneumonid and Braconid parasites, so that they are not capable of penetrating very thick bark, but usually select that on young trees or the branches of old ones, unless the insect they seek to attack works in the outer portion of the inner bark and makes its pupa cases in the outer bark, as does the destructive spruce bark beetle.

The Chalcids are common parasites of the bark beetles in all kinds of trees, and especially so in spruce and pine, and as I 
have often seen, literally swarm around small trees infested by this class of bark miners.

The habit of the Chalcid larva is similar to that of the Braconid, that is most of them which attack bark mining grubs are external parasites, but unlike the Braconid, they rarely make cocoons, but instead, undergo their transformation in the cavity left by their victim. The adult bark beetles are also attacked by Chalcid parasites, in which case the Chalcid lives in the abdomen of its victim.

See list of Chalcids in Appendix for reference to habits of species.

\section{TACHINID PARASITES.}

It is common for two-winged flies to attack caterpillars and the adults of insects which live in the open air, but it is not conımon for a fly to attack bark and wood mining insects. In fact there appears to be but few records of their doing so. It is the habit of this class of parasites to glue their eggs to the surface of the body of other insects. These eggs hatch into minute maggots, which burrow into their host and teed upon the liquids. The adults are not provided with horny ovipositors as are the three classes of parasites above mentioned, so it would seem difficult and almost impossible for any of this class of parasitic insects to attack the larvae of bark beetles, yet I have found the larvae and cocoons of a small fly (Medeterus nigripes, Leow) so common in the larval mines of the destructive spruce bark beetle that there appears to be no doubt of its being a primary parasite of the larvae of this beetle; but how and where the eggs are deposited, and how the minute, slender maggot finas its way to the bark mining grub, I have not as yet been able to determine.

Another undetermined Dipterous larva was also commonly found associated with the larvae of the spruce bark beetles in such a manner as to indicate that it was an enemy of this class of bark miners.

\section{DISEASES OF INSECT EMEMIES OF THE SPRUCE.}

Both the bark and wood mining insects, adults as well as larvae and pupae, are subject to attack by fungus diseases, and 
many individuals are thus destroyed. The insects which have died from disease are usually coverea or surrounded by a snow white or yellowish mass which is the external growth and spores of the fungus which caused their death.

BIRDS AS FRIENDS OF THE SPRUCE.

Woodpeckers and other birds douhtless destroy vast numbers of insect enemies of the spruce, but at the same time they necessarily destroy many of the predatory and parasitic insects, yet I would recommend the encouragement and protection of all insectiverous birds, since they are undoubtedly of very great service in preserving a balance among the contending species of plant and animal life, and at times may render most valuable service in reducing the numbers of dangerous insect enemies.

\section{OTHER BENEFICIAL ELEMENTS.}

Certain climatic conditions has much to do with the destruction of insect enemies of the spruce, far more indeed than is generally supposed. But since it has possibly quite as much influence in contributing to the multiplication and spread of these enemies, and in bringing about devastating invasions of the most destructive species, it would be difficult to say whether more good or harm results from this source. Unless we assume that without the favorable conditions offered for the devastating invasions, there would be no need of opposite conditions to destroy them, when we must conclude that the harm resulting from such influences is far greater than the benefits. After all, such influence for good or harm is beyond the control of human efforts and need only be considered in this connection to explain certain renıakable phenomena in the rapid multiplication and spread of the destructive pine bark beetle over thousands of square miles and its sudden and complete extermination over the entire invaded area ; which subject is fully discussed under this head in the report on the pine investigation.

To what extent the other insect enemies of the spruce are influenced by a series of warm winters and wet or dry summers, 
or extreme cold or heat, I have not as yet determined, but sufficient evidence is bad to indicate that with some species it is quite marked, while with others there is no perceptible influence one way or the other.

While we are powerless to control the climatic conditions, except in a conservation of the forest covering of the spruce area there is much to be gained from a knowledge of the rotation of certain climatic conditions to the distribution or destruction of noxious insects generally, since we could thus indicate what may be expected to follow any abnormal conditions in the climate of any single year or series of years; also we would be able to tell what insect foes or friends may be looked for within given areas of different elevation within the State. Therefore it is a subject to which I hope to devote considerable attention in the future. 


\section{PART II.}

\section{THE PINE INVESTIGATION.}

THE PINE OF WEST VIRGINIA.

Five native kinds or species of pine are more or iess common in West Virginia, viz: the white, yellow, pitch, scrub and table mountain pine. The loblolly, or old fleld pine has been recorded $^{1}$ from the State, and evidence is had that the red, or Canadian pine occurs in at least one locality.

The White Pine is a large tree with light colored bark and with narrow, soft, light-green leaves, four to five inches long, growing five in a bundle; the cones are slender, curved and four to six inches long. This valuable representative of the pine family grows to a large tree in the sections of the State where the conditions are favorable for it, sometimes attaining a height of 125 feet and a diameter at the base of over 4 feet. It is widely distributed over the State, forming typical forests of greater or less extent in Pocahontas and Greenbrier on the eastern waters of the Greenbrier river, and in Raleigh county, on Perry creek; in Summers and Monroe counties. on Bluestone river; in Preston and Tucker, on the waters of Cheat river; in Pendleton and Hampshire and South Branch mountain on the Potomac waters; in Calhoun and Gilmer, near the Little Kanawha river ; in the central part of Ritchie and northern portion of Marion counties along the B. \& O. R. R. I have also observed it along the Little Kanawha river in Wood and Wirt ; in Hampshire on North river, at foot of Ice mountain ; Grant, along West Virginia Central R. R.; Randolph, on Dry Fork of Cheat; Marion, along the Monongahe'a river at Nuzums, and Monongalia, near Morgantown.

The Yellow Pine is next in importance to the white pine, and grows to a large tree. It has soft, thin and flaky bark, the leaves are slender, dark-green, three to five inches long, and grow two and three in a bundle, more frequently the 


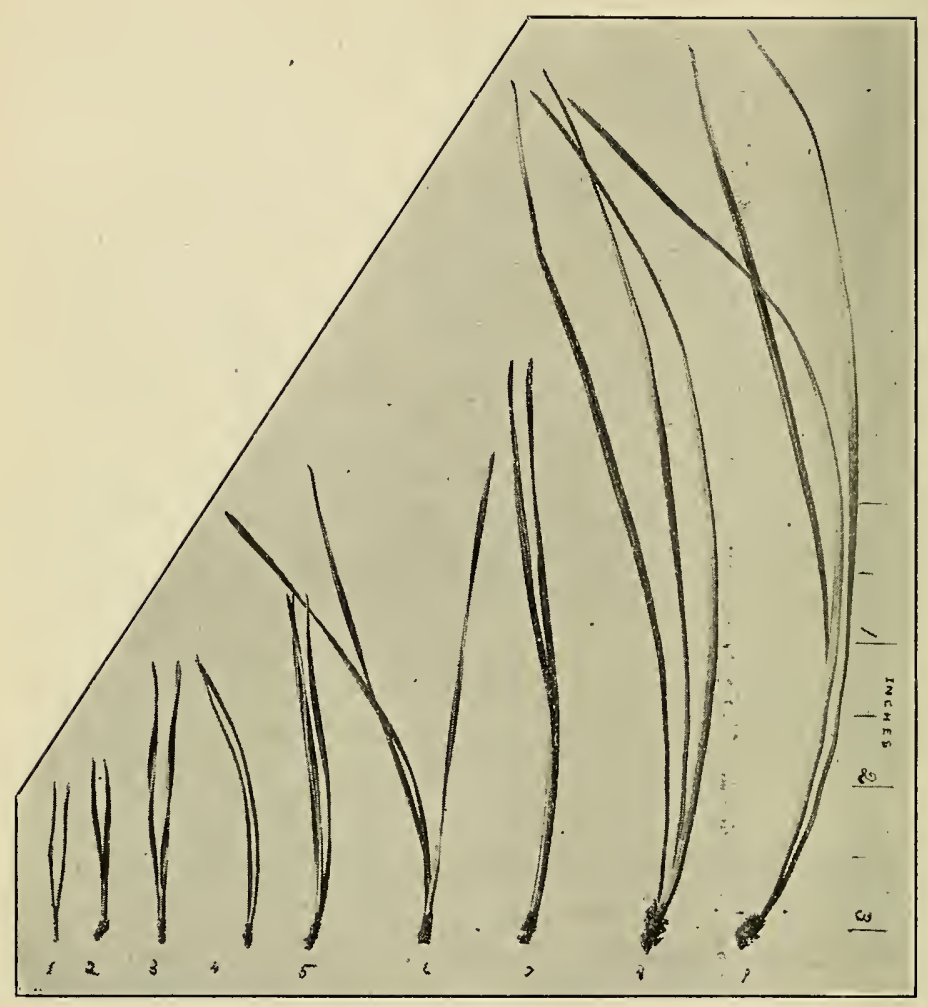

Fig. XXXIII.-Pin Needles. 1 scrub pine; 2 and 3 table mountain pine; 4 yellow pine; 5,6 and 7 piteh pine; 8 and 9 hybrid (") piteh and red pine.

former number. The cones are small, $1 \frac{1}{2}$ to 2 inches long and usually grow in pairs on small twigs. This pine is widely distributed throughout the eastern, sonthern and westeru sections of the State, and was originally found in abundance and great perfection in the hilly region of the counties, south of Marshall, bordering on the Ohio river. Here it grew 120 feet tall, or more, and over 4 feet in diameter; at present it occurs nowhere in pure forests, but mixed with other pines and hardwoods.

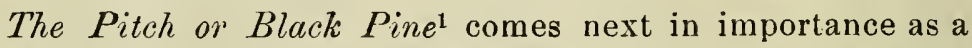
timber tree. It may be recognized by its dark, coarse bark 
and its stiff, dark, yellowish-green leaves, 4 to 5 inches long, and growing three in a bundle. The cones are 2 to $3 \frac{1}{2}$ inches long, often occurring in clusters. This pine grows to a large tree, 60 to 75 feet high, and from $1 \frac{1}{2}$ to 2 feet in diameter. It is widely distributed over the State, forming forests on some of the mountains in Hampshire, Hardy and Pendleton counties, and occuring at high altitudes in Preston near Cranesville.

The Scrub or Virginia Pine comes next in importance; not so much on account of its value as a timber tree, as to its common occurrence and wide distribution over all of the areas of the State upon which the pine occurs. It is easily recognized by its scrubly growth, its thin, fluky bark, and its short, fine, yellowish-green leaves, 1 to 3 inches long and growing two in a bundle. The cones are 2 to 3 inches long, growing single and in clusters, and usually abundant on old trees. This species seldom grows large enough to be profitably worked into lumber ; being a medium sized tree, 20 to 30 teet high, and 6 to 12 inches in diameter, rarely exceeding the

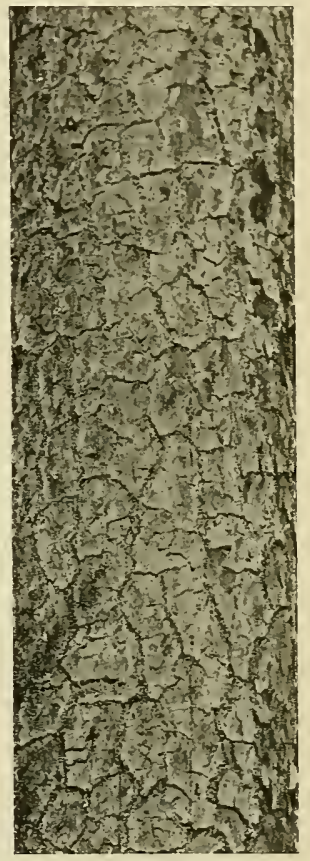

Fig. XXXIV.-Trunk of yellatter, although $I$ have seen trees of this pine that measured over 18 inches at the base. It grows where the other pines will not thrive; on poor; southern, or western slopes, and in old fields. It is of little value except for feul and mine props, for both of which it is extensively used in certain localities.

The Table Mountain Pine. ${ }^{2}$ This is a larger tree than the scrub pine, with coarse bark, short, stiff, yellowish-green leaves, $1 \frac{1}{4}$ to $2 \frac{1}{2}$ inches long, growing two in a bundle. This pine can be readily distinguished from all of the other native pines by

1 Pinus Tirginiana, Mill, 2 Pinus pungens, Michx. 
its excessively large, spiny cones, which are three to four inches long and grow in clusters on the central shoot of young trees and the terminal branches of old ones. The cones are often so firmly attached to the wond that they remain on the trees for many years, and are sometimes covered over by the bark and wood; immense numbers of cones occur on old trees. This pine is common in old hrghland fields, and on the mountains and foothills of Hampshire, Grant, Mineral and Pendleton counties, but so far as I have observed, it does not occur west of the mountains. It grows to a height of forty feet and a diameter of eighteen to twenty inches, but like the scrub pine is of littie value except for fuel and miue props.

The Loblolly Pine. ${ }^{1}$ This resembles the pitch pine, except that it has longer leaves and larger cones. While this is a common and valuable tree along the coast from Delaware southward, in West Vrrginia it is of rare occurance. According to Millspaugh (Bulletin 24 of the W. Va. Expt. Station) it occurs along the table lands in Mineral, Hampshire and Hardy counties and also in Wood county; but so far I have failed to recognize it in any section of the State. The pine referred to in Wood county, which I have seen, is not this species, but probably a variety of the pitch pine.

The Red Pine or Canadian Pine.2 This, according to Britton, (Illustrated Flora, Eastern U. S. and Canada, p. 51,) is a "tall forest tree, reaching a maximum height of about 150 feet, and a diameter of five feet, the bark redish, rather smooth, flaky when old; leaves two in each sheath, 4 to 6 inches long, cones $1 \frac{1}{2}$ to 2 inches long, and usually less than one inch thick."

Although I have not seen living examples of this tree, I have evidence that some fine examples grow on the borders of the spruce and larch or "pine" swamps near Cranesville, Preston county, at an elevation of about 2,600 feet above tide. I saw the stumps, bark and wood, which agrees with the description, and since the Canadian conditions prevailing there are especially favorable for the occurance of this northern tree, it seems very probable that the large trees referred to belonged to this

1 Pinus taeda, L. 2 Pinus resinosa, Ait. 
species. The pitch pine was alsc found near this locality, and another which from the exceedingly long leaves and nearly smooth cones appeared to be a hybrid between the red and pitch pine. See Fig. XXXV.

There is another pine which is frequently met with in the mountains near Morgantown, which in character of growth,

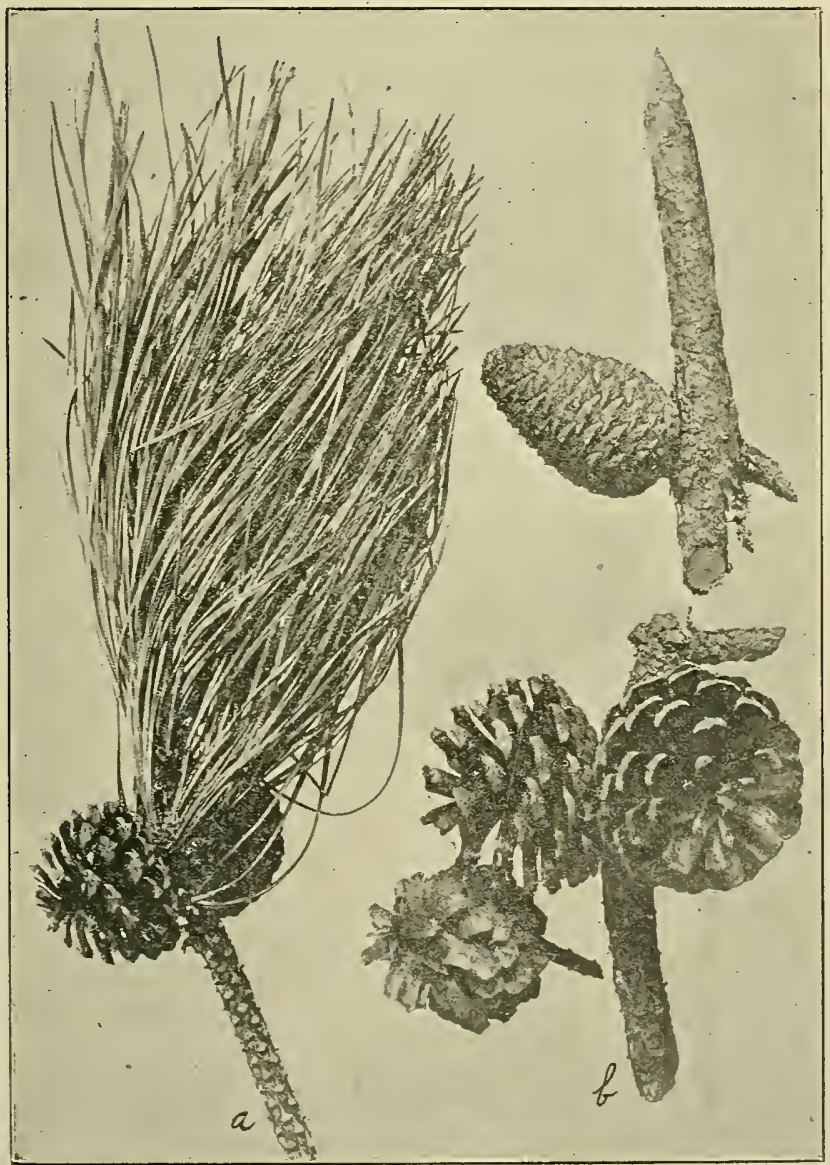

Fig. XXXV. $-a$ Branch from pitch pine, or hybrid pitch and red pine: leaves $6 x 7$ in. long: $b$ cones from pitch pine: $c$ unopened cone of pitch pine. 
bark and wood, resembles the yellow pine, ( Pinus echinata, ) but the leaves are uniformly three in a single sheath.

COMNERCIAL PRODUCTS OF PINE.

In this State the principle product from white and yellow pine is lumber, the latter furnishing, up to twenty years ago, the most desirable flooring material. Both have yielded an immense quanity of riven and sawed shingles, lath, pickets, etc.

The young growth of all kinds is extensively used in some localities for mine props, and where abundant, yield a considerable revenue,- the pitch and scrub pine being, in some mining regions, the favorite of all for this purpose. All of the pines furnish, while not the best, a large amount of merchantable cord wood for fuel and charcoal. They also yield in the socalled "rich"logs, knots, and stumps, a considerable quantity of tar and pitch. While turpentine is obtained to some extent from the living trees.

PAST AND PRESENT CONDITION OF THE PINE OF WEST VIRGINIA. ORIGINAL DISTRIBUTION.

It is evident from available records and present indications that at one time, possibly not later than 250 years ago, the predominating forest :trees over large areas in the southwestern third of the State, as well as in the southern and eastern sections, were pine, and that the isolated forests, and the groups and individuals of the white, yellow, pitch, scrub, and table mountain pines that we find at present, are living examples and lineal descendents of extensive primitive forests of one or more of the species mentioned.

That the yellow pine occurred in abundance throughout the southwestern counties, whenever the conditions were favorable tor its growth, there can be no doubt. I can, myself, remember when it was a common and valuable timber tree in my native county-Jackson. In fact, an unuswally fine specimen of this species attracted my first attention to forestry questions, and was the subject of my first observation on forest tree insects. It was some twenty-five years ago; when my grandfather called my attention to a yellow pine tree growing in a western 
"cove" in his forest land, and remarked that it was the largest tree of the kind that he had ever seen. I was forcibly impressed with its size and beauty, and often stopped to admire it during my hunting expeditions in the primitive forest in which it grew. It was a magnificent specimen, evidently over four feet in diameter, and not less than one hundred and twenty feet tall, apparently one hundred feet of which was a straight, limbless trunk, probably as large twenty feet up the trunk as it was at the base. There were also at this time a large number of yellow and pitch pines in this same forest, but none nearly so large as this. A few years after my attention was first called to this tree, I noticed that it had a peculiar appearance, and upon examination I founcl that the woodpeckers had removed all of the thin, flaky, outer bark from the trunk, and that the bark was punctured with innumerable holes resembling shot holes. Upon removing a piece of the bark it was found to be grooved in all directions by bark mining insects, and that the tree had recently died evidently from injury by the insects. The tree was soon after cut and worked into shingles in order to prevent the total loss of its valuable wood.

This tree was evidently a surviving representative of the vast quantities of this kind of timber that once grew throughout the southwestern sections of the State, forming in the most favorable Iocalities nearly pure forests of the species, and occurring in other sections in a mixed growth of hardwood and other kinds of pine.

PRESENT DISTRIBUTION AND CONDITION OF THE PINE IN THE STATE.

At present the occurrence and distribution of the best types of the different species of pine are restricted to a few scattering individuals and small forests in Morgan, Hampshire, Mineral, Grant and Pendleton counties and the south-western portion of the State, and a few primitive forests of white pine which oceur in Raleigh and Greenbrier counties. There is a considerable amount of young seedling or scrubby growth of white, yellow, pitch and scrub pine in all of the sections mentioned, 
but in many localities where the pine has been removed, their places are being occupied by the oaks and other hardwoods.

Living examples of the different species of pine that are now standing, and are exempt from the effects of forest fires, are apparently.in a more healthy condition than they have been for many years. In the present pine areas of the State I would. judge that ninety per cent. of the merchantable pine timber has been removed or has died. There is, however, a cousiderable amount of young pine, especially in the eastern, southern and western sections of the State, which if protected from fire would soon produce a large amount of valuable timber.

INFLUENCES WHICH HAVE CAUSED THE DESTRUCTION OF THE PINE TIMBER OF THE STATE.

From the time the first settlers entered the several sections of the State where the pine grew, to the present, the pine has suffered more severely perhaps from the influence of civilization, and from its numerous natural enemies, than has any other of our commercial timber trees. This is due to their susceptibility to injury and destruction, from changed conditions and effects of fire; to their numerous insect and other enemies; and to the fact that they furnished to the early settlers the first and most desirable forest products of a commerical value, as well as convenient and more suitable material for the rudely constructed farm houses, and outbuildings of the pioneer farmers.

Thus, in all the regions in which the pine predominated or occurred in mixed forests, the tall, straight trunks of the white, yellow, pitch, and even of the scrub pine, were selected for building material. They used the hewn logs for the walls and joist, pine poles for the rafters, pine shingles for the roof. and even pine sticks for their clay and stick chimneys. As the country became more thickly settled timber began to have a commercial value for shipnent to market. At this early date the white and yellow pine. were the only kinds worth cutting for this purpose (except perhaps a limited amount of poplar, walnut, cherry, etc.) At first, the best trees and those only 
which grew convenient to the larger rivers and creeks were sejected, in order that they might be the more readily made into rafts and thus floated to the water power sawmills, or to market. For a long time the upright, water power sawmills were the only means of home manufacture of lumber, except the more primitive and laborous method of "whip" sawing by hand. Later, portable steam sawmills were located farther back on the smaller streams, where the logs were converted into lumber and hauled with teams to the large streams, and then floated to market. Still later, flatboats were used to transport the lumber, and extensive sawmills were located at the mouth of the large streams where floating logs were held in booms until they could be converted into lumber.

I'hus, the best yellow pine was called out and marketed from all of the more thickly settled and accessible regions, before the other kinds of timber had any commercial value.

T'his culling out process and leaving the tops and broken or injured trees in which the insect enemies bred and multiplied, together with the changed conditions brought about from clearing large areas of land, and the consequent frequency of forest fires, combined to weaken the vitality of the remaining pine timber, resulting in destructive invasions of insects, and the death of vast quantities of young and old timber.

Thus the process of natural and artificial destruction of the pine has been going on in all of the pine areas until it culminated within the last five years in one of the most extensive devastations of timber by destructive insects that has ever been witnessed, or at least recorded in this country, which not only swept over the pine regions of this State, but that of Pennsylvania, Maryland, Virginia, and North Caroliua, killing millions of pine trees of all kinds and ages above a diameter of a few inches. Fortunately, this last 'serious trouble is over for the present at least.

When we come to look over the field of devastation we find, like the effects of a series of great conflagrations, or destructive tornadoes sweeping over the country, that while immense and 
irreparable damage and loss of property has resulted, it might have been far worse, since we find that in the aggregate there is left quite a large amount of healthy, vigorous pine of all kinds, ages and sizes, as previously noted. It has also been the means of extensive investigation, which it is believed will, in the knowledge gained in reference to the causes and character of the injuries and methods of preventing the reoccurrence of like invasions, be of sufficient value in the future to compensate in part for the loss sustained.

THE RELATION OF THE PINE IN AMOUNT AND VALUE TO OTHER KINDS

OF FUREST TREES.

While the pines, except perhaps the white pine, are no longer of much commercial importance in this State as compared with the spruce, the hemlock, the oaks, and the yellow poplar, on account of their disappearance from the accessible regions where they were once so common, we have yet, in the remaining areas pure or mixed forests of healthy pine-especially in the eastern and southern sections where they hold first rank as forest trees-which if properly cared for will be quite as valuable, on account of their lumber products, as are some of the more fertile lands for the cultivated crops they yield.

Revenue from Pine. The revenue derived from the pine timber of the State in the past has been many millions of dollars, and did much towards contributing to our present advance. ment, and the aggregate wealth of the State. The amount of healthy timber yet standing, while apparently not of much importance as compared with other kinds of timber, has an inestimable value, both on account of its actual money value and what it promises in the timber supply of the future. Just as the pine was the first to be selected by the pioneer as the only tree of commercial value, and the first to disappear trom the mixed forests, so will it be the first selecterl as the most practicable kind of timber to grow under the future system of forest management and protection, which must necessarily follow the present system of forest destruction. 
RATE OF CONSUMPTION TO THAT OF NATURAL INCREASE.

Up to within the last three years the rate of consumption and natural destruction of the pine has been greatly in excess of the natural increased growth, but I should judge that at the present time the rate of aggregate increase is almost or quite equal to that of the consumption, and with a little protection of the young growth, the aggregate increase would exceed the consumption.

COMPARATIVE VALUE OF SECOND GROWTH PINE TO THAT OF OTHER KINDS OF TIMBER TREES.

While the pine does not, as a rule, sprout from the stumps or roots as do the oaks, hickories, etc., it is far more rapid in its growth from seediings, and will occupy the land much more completely than any other kind of timber. In fact, the aggregate growth of commercial wood per acre of the white pine under cultivation, where the conditions are favorable for its growth, ${ }^{1}$ will doubtless exceed that of any other timber.

The kind of land on which the white and yellow pine grow to perfection is usually of the least value for agricultural purposes. Hence, when it becomes necessary for us to adopt a system of forest culture, such lands will necessarily be selected for the purpose, and in many sections it will not be necessary to plant out the trees, since the land if left alone for a few years will be covered with a thick growth of young pine.? With a little care in removing the inferior kinds, and thinning out the inferior and surplus growth they will soon grow into useful timber, and in a comparatively short time will yield a revenue to the owner from the sale of the timber product, equal if not greater than could be had from the land by any other method.

THE PRINCIPAL ENEMIES OF THE PINE.

The natural enemies of the pine are many, and owing to the

1 In Europe it has at the end of seventy years from planting yielde the enormous amount of 14,000 cubic feet of wood, containing about 50.000 feet of lumber $B$. M. per acre.-Report of Division of Forestry U. S. Dept. of Agr., 1893, p. 349.

2 Excellent examples of the truth of this statement is found on Piny Creek in Raleigh county, where 1 have seen one year old seedlings covering many old fields like a thick growth of weeds or grass. 
sensative nature of the more valuable kinds; as the yellow and white, they suffer more severely on this account than does any of the other kinds of timber trees. Man has, of course, been its greatest enemy in its direct destruction, and in bringing about changed conditions which were unfavorable for its heaithy growth, also as the originator of forest fires, which is perhaps its greatest enemy, insects come next and ranking nearly as high as fire. As a destructive enemy of large trees it has in this State caused a far greater loss of such timber than has fire. Fire is however, more destructive to the young growth. Heavy wind, snow-storms, etc., are other serious enemies or destructive elements to the pine, while numerous small and large animals may be classed among its natural enemies.

The destruction of valuable pine timber, within recent years over vast, aggregate areas in this and adjoining States, by one species of insect aided by its numerous insect and other allies has rendered the investigation of the trouble and a study of the past and present conditions and distribution of the pine in West Virginia the most extensive and important work undertaken by this department of the Station.

With what additions I have been able to make from personal observations it is found that over 400 different kinds of insects infest the pines of North America, the greater number of which occur in the eastern United States. I have fonnd, however, out of this vast number, that those kinds which are capable of attacking healthy trees, and killing them on their own account, do not exceed possibly a half a dozen species, and probably but one that is capable of causing widespread devastation of pine timber. This is the destructive pine bark beetle, (Dendroctonus frontalis, ) which will be fully discussed further on in this report.

\section{HISTORY OF THE INVESTIGATION.}

TO DETERMINE THE CAUSE OF THE UNHEALTHY CONDITION OF THE TIMBER.

First Information,- My attention was first called to an unhealthy condition of the pine by Capt. Parsons, of Davis; W. 
Va., when I was there in March, 1891, conducting investigations in the spruce forests. In the course of a conversalion with this gentleman in regard to the trouble that had affected the spruce, he remarked that he was convinced that my conclusions were correct with reference to the spruce having been killed by insects, since he had observed, while traveling through Bath and Highland counties, Virginia, in the summer of 1890 , that the pine on the western slope of the Warm Springs and Jackson river mountains was dying as if killed by fire, and upon closer examination no fire or other external injury was observed, but the living bark was found to be infested with great numbers of little black bugs and small white worns, which he concluded must have caused the death of the trees. Capt. Yarsons stated that this dying condition of the pine exteuded for a distance of seventy miles along the western slopes of these mountain ranges.

I was anxious to investigate this matter, thinking it would throw some light upon the canse of the death of the spruce, but the trouble being in another State, I could not do so.

\section{FIRST OBSERVATIONS.}

During an extended journey through the State in July, 1891, I visited Hampshire county on July 12th, with the hope that I would find some indications of the trouble in the pine forests there. I had but one day and night to spend there, however, and necessarily could not accomplish much. I procured a horse and buggy and drove ont some five or six miles from Romney, where I was fortunate in finding a group of five dead pine trees. They were some distance from the road on a steep monntain side, but I managed to get to them, and made a hurried examination. The trees were found to have been dead some time, possibly three or four months. A brood of bark beetles had emerged from the bark on the upper portion of the trunks, and the bark was dead and readily separated from the wood. No living examples of the insects that had bred in the upper bark were found, but numerous dead examples of the parent beetles, (Dendroctonus frontalis) were taken from the old 
brood galleries. 'T'he bark on the base of the trunk and on the roots was yet living, which together with the partly dead bark was infested with larger bark beetles, (Dendroctonus terebrans.) The bark beetles taken from these trees were subsequently determined for me by Mr. W. Eichhoff, of Strassburg, Germany. ${ }^{1}$

It was evident to me that some of the insects taken from the bark were to blame for the death of the trees, but of course I could not arrive at any definite conclusions in so short a time. The next day as I was going back, $I$ found on another tree that had just commenced to die, and upon discovering a number of the turpentine bark beetles ${ }^{2}$ in the living bark at the base, I was inclined to believe that this insest was, possibly, the one to to blame for the trouble.

A considerable number of dying trees were observed on the mountains in this county sufficiently common, indeed, to indicate that it was an unusual occurrence.

Not having the opportunity to conduct further personal investigations of this trouble during the summer and fill of 1891 , I had to rely upon what information I could obtain from correspondence.

\section{CORRESPONDENCE.}

In September I received a letter with specimens of insects from Mr. J. S. Strayer, in which he said :

"I send by this mail a lot of bugs and grubs, secured from a large white pine growing in a private yard and entirely isolated from any body of woods whatever. There are about a dozen large forest trees growing in this yard, amongst the number three or four very fine specimens of white pine. The balance of the trees are oak, and common park trees, locust, etc. One of these pines is rapidly dying. In fact, has died, except the lowest branches which are still green. I examined the tree closely, and found rosin exuding frem a thousand or more little holes. Securing a hatchet, I cut through the bark and secured the specimens herewith enclosed. The red head bug I found under the bark, but it is possible for it to have gotten there after I cut in. The others, bugs and larvae I found just under the skin of the bark. I send a couple of bugs in the bark as they were when I got them."

In my rcply, October 3, 1891, I said: * * * The small beetles belong to the genus Tomicus. * * The red-headed bug * * is a bene-

1 Colydium tineola, Sav., Dendroctonus terebrans. Oliv.. Dendroctonus frontalis, Zimm, Pityophthorus confinis. (?) Lec.. Tomicus cacographus, Lec., Tomicus calligraphus, Germ., Cossonus corticola, Say, Pissodes strobi, Peck.

2 Denaroctonus terebrans, Oliv. 
ficial insect in destroying the Tomicus and other injurious bark beetles. The small grubs are probably the larvae of the Tomicus.

On Oct. 3d, the Directer received a letter from Mr. Adam Fisher, Moorefield, W. Va. This letter we quote in full:

"DEAR SIR :-A large percent. of the pine trees in this section are dead and dying, all kinds. Respectfully,

AdaM Fisher.

In my reply on Oct. 6 th, to this letter, I said :

"Your letter of Oct. 3d to Dr. Myers has been referred to me. In reply I will say that more than likely the pine ** is dying from insect attack. * * * Wiil you kindly aid me by answering the following questions. 1

Please examine under the bark near the ground and on the trunk of the trees that are just commencing to die, and also the living trees near those that are dying. If you find any kind of a bug or grub, large or small, under the bark or in the sapwood of these trees, please forward some of them to me in the bottles I am sending you by this mail. Get all of the different kinds you can find, and if you find any in a perfectly green tree, they will be especially desired. ** Please give me all the information you can regarding this trouble. * *

On Oct. 9th Mr. Fisher wrote as follows:

"SIR:-Yours of the 6 th inst. came to hand last evening; also bulletins and box of bottles. I live at the base of a mountain in full view of a large area of timber. The clead pines easily discerned. I went out this morning to a group of dead pines that were in full view of the house. They proved to be yellow pine of good size, fit for lumber. I examined about half dozen that had the appearance of being dead from a distance, and found them entirely dead and infested under the bark with numerous insects of different colors, sizes and shapes. Some had penetrated the wood, not many. The bark that I send you will demonstrace how they work.

The trees of the same kind (yellow pine) that stood near were either dead or living, not half dead.

The depredations on the living were slight, like an attack and abandoned.

The bark I send you will show the work of the bug, also of the small insects, which are very numerous, white ones predominating.

I only use three of the bottles, reserving the others for better test. The white grub, second size, I got from the bark of a live tree.

I must answer your questions in accordance with my slight examination.

'What kind of pine?' 'Yellow.'

'Is it valuable?' 'It is '

'Does it die in patches?' 'It does.'

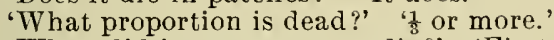

'When did it commence to die?' 'First one noticed this snmmer.'

"If you come I will entertain you."

In my reply, Oct. 14th, 1891, to this letter, I sald:

"I have your letter of Oct. 9th. The package of insects and bark, all of which is very interesting to me, for which, please accept my thanks.

The small black beetles are probably the principal insects to blame for the death of your pines. The holes in the bark you sent were made by these beetles and the small channels on the inside of the bark were made by small grubs which hatch from their eggs. The technical name of the 
beetle is (Dendroctonus frontalis.) The red looking grub you sent feeds on this and other insects, therefore you made a mistake in placing it in the bottle with the other specimens, for it has devoured many of them. The large worm probably enters the bark after the tree commences to die. The one you found in the live tree is usually found in the outer bark of such trees, therefore can do no damage.

There is another insect about three times as large as the small black ones which I suspect as being among the principal ones to blame for the death of the trees. They work under the bark near the root of the tree, sometimes even under the ground. I found them near Romney last summer in perfectly green trees, working in the turpentine under the bark. I also found them under the bark of trees which had recently died; there. fore, I hope you will look carefully for them and others like them in green and dying trees. Send a bottle full of eacli hind of the small round-bodied beetles you find in the bark of the trees.

I may visit your section next month, but if I do not. I would like to arrange to have you send me by freight some sections from smali trees infested by certain insects.

The only remedy we can think of to prevent the spread of the trouble among your timber is to introduce some kind of insect that will destroy the injurious species. I am now arranging to import some parasites from Virginia, Germany and France to put after some of our insect pests."

\section{Mr. Strayer wrote again on Oct. 1Sth, 1891, as follows:}

"I send by this mail a box containing several species of bugs, etc.. found under the bark of dead, yellow pine (still standing.) The shells of bugs enclosed were all found together in a nest under the bark. The worm like larva was found near the root of the tree. I traced his passage for about four feet until I found him./ He left a passage way of at least $\frac{3}{8}$ inch. The red-headed bug was first put in a vial with the Tomicus, when it immediately attacked the 'cus.' I send chip to show how the chip was literally riddled."

\section{In reply to this letter I said:}

'I have just received your lelter of the 10 th inst., and the box of insects of same date for which please aecept thanks.

The large grub or larva you found in the dead pine is commonly called the Sawyer. When they are boring into the wood, the sound produced resembles that of an auger. The larvae change to beetles in the spring. The beetles then deposit their eggs in the bark of recently cut pine logs or trees, which have commenced to die. The red-headed beetle is (Thanasimus dubius) and the red larvae are the larvae of this same species. This beetle and its larvae feed upon Tomicus and like beetles.

The shells which you supposed to be that of bugs found in a nest are the empty egg cases of the common wood roach.

The Tomicus and like beetles are very interesting to me. Am sorry you did not send more of them, I believe that the Dendroctonus terebrans, (like the one you sent to Washington) are the principal insects to blame for the death of your pines.

The more you send of each species of beetles like Tomicus and Dendroctonus, the better. They belong to a family of beetles called Scoly. tidae containing several hundred species, nearly all of which are more or less injurious to forest and fruit trees.

I have a correspondent in France and one in Germany with whom I am arranging to import some live parasites of these Scolytids to experiment with in sending them after our injurious species. This seems to be the only practical remedy to be thought of to check or prevent their ravages." 
From the information obtained from the above correspondence with Mr. Strayer and Mr. Fisher, together with what observations I had made, was sufficient to convince me that a very serious trouble was affecting the pines over a large area of West Virginia.

\section{SPECIAL INVESTIGATION COMMENCED.}

By the following spring the trouble was found to be of such a serious and threatening character that it was decided to make a special investigation of the trouble, and on May 23d, 1892, I entered the pine region of Hampshire county for the purpose.

The first thing to attract my attention upon entering this county was the increased number of groups of dying pine on the mountain slopes, and as I drove through Hampshtre, Hardy, Grant and into Pendleton county along the South Branch of the Potomac river, I had an excellent opportunity to observe the remarkable and interesting character of the trouble.

THE CHARACTER OF THE TROUBLE DESCRIBED.

The conditions as they were observed in the different counties gave a good idea of the commencement and progress of the trouble. In Hampshire county groups of trees from a few to fifty or more were observed upon which the foliage was turning yellow, had already died, or had taken on a reddish brown hue, which is characteristic of the leaves of pine trees killed by fire. 'These groups of affected trees occured all through the pine forests, separated by spaces of healthy timber varying from a few hundred yards to a half mile or more. The yellow leaves of the dying trees, and the reddish brown of the dead ones, showing in marked contrast as they occured in the surrounding mass of green foliage of healthy trees.

As I proceeded further up the river into Hardy and Grant counties, this peculiar diseased condition became more common. Many groups of dying and dead trees here covered one to fifty acres each, and as the central portion of Pendleton county was reached, nearly all of the pine on entire mountain ranges was found to be dead. 
INVESTIGATIONS TO DETERMINE THE CAUSE OF THE TROUBLE.

With a view of obtaining as much evidence as possible with reference to the cause of this wide spread devastation of timber, I carefully examined a great number of living, dying and dead trees in all sections of the forest visited. The possibility of the primary cause of the trouble being due to the action of some bacteria or fungus disease, or some unfavorable climatic condition which would weaken the vitality of the trees and thus attract the bark beetles, led me to give this phase of the subject careful consideration, and to search for evidence that might lead to this explanation of the phenomenon.

Trees Dying from a disease. A few small trees of the scrub pine 1 were found in Hampshire county, and occasionally observed in other sections, which were without doubt, dying or had died from the attack of a disease which cansed the rapid decay of the roots and base of the trunk, being similar in this respect to a so called root rot disease that kills fruit trees in some sections of the State. The bark on the roots and base of the trunk dies first, then the leaves gradually die and turn red, as they do when the tree is killed by fire, and remain firmly fixed to the twigs. The roots rapidly decay, and are usually coated with the mycelium (?) of a fungus which also extends beneath the bark on the roots and trunk of the tree. By the following year the sapwood of the roots is completely decayed, and the tree falls to the ground. Trees dying from this trouble, while of frequent occurrence in some localities, were rare in other sections where the greatest number of trees were dying from the common trouble. They were not found in groups, but isolated and widely scattered through the forests.

TREES DYING PROBABLY FROM NATURAL CAUSES.

As is common even in the healthiest pine forests, large trees of all species were frequently met with which had, evidentiy, died from what is termed natural causes, such as so called old age, or more correctly speaking, from the soil being occupied 
by the roots of younger and more vigorous competitors. In all such trees, as in those dying from disease, the bark at the base of the tree was dead at the same time, or before the leaves and branches commenced to die, thus indicating that the primary cause originated at the base of the tree, or in the roots.

\section{A PECULIAR CHARACTER OF THE COMMON TROUBLE.}

In striking contrast to the characteristic conditions of trees which had died from disease and natural causes to those which were dying in groups over large areas was that the latter were found to be living at the roots and base, while the tops were dead or dying. In fact, trees were commonly met with, the tops of which had died during the spring and summer of 1891 , vet the bark on the roots and base of the trunk was at that time (May, 1892,) in a normal condition, and in rare cases, young sprouts, especially on pitch pine, were growing on the main trunk near and for some distance above the ground; thus indicating beyond all doubt that we must look for the cause of this common trouble in or near the top of the tree. ${ }^{1}$

THE CAUSE OF THE COMMON TROUBLE DISCOVERED.

In every one of the large number of trees that I examined, which had commenced to die from the top, and the roots and base of the tree were living, I found the bark on the upper por tion of the trunk infested by the same species of bark beetle as the dead ones found in the trees examined in Hampshire county in July, 1891, determined by Mr. Eichhoff as Dendroctonus frontalis. Examples of the insect occurred in all stages from the egg to the adult, and in the bark of some trees were exceedingly abundant. Neither the pitch, scrub, yellow, table mountain, or white pine were exempt from itsattack, and the largest as well as the most vigorous and medium sized young trees were alike invaded by it. Pine trees of all species and sizes above a few inches in diameter were observed in considerable numbers, the leaves of which were green and in normal

1 This protracted vitality of the roots and base of the trunk was subsequently found to be one of the most common and characteristic conditions with all kinds of indigenous and cultivated pines and-spruces in every section of the State, and all kinds of soil where the trees died from the common epidemic of 1890 to the spring of 1893. 
condition, as was the bark on the trunk at the base, and from six to ten feet above. Upon close examination when felled for the purpose, and of those recently felled for saw logs, I found the bark on the upper portion of the trunk to be infested with the same bark beetle, (Dendroctonus frontalis) together with conclusive evidence that this insect had made the primary attack and had mined in ail directions through the living bark in which eggs had been deposited and the young grubs had developed, long before any other insect had attackerl any part of the tree. On some trees, the leaves of which were yet normal the bark on the upper part of the trunk was dead and infested with fully developed larvae, pupae and recentiy matured adults.

The fact that examples of the bark beetle, (Dendroctonus frontalis,) were associated with every one of the hundreds, or I might say, thousands of the dying trees that I observed or carefully examined; that the adults were frequently found mining in perfectly healthy bark of living trees; that they were capable of living in and manipilating the pitch that flowed into their freshly excavated galleries through the lark; and that all stages of the insect occurred in the bart of trees that were not yet dead, was conchusive evidence to me that this insect was the prime cunse of the widespread epidemic from which so many trees had died and were then dying.

Upon my return to the Experiment Station, I prepared the following article, a copy of which was sent to the State and county papers. It was subsequently published in a large number of newspapers of this and adjoining states and extensively commented upon by some of the principal newspapers of the Eastern and Southern States.

The object of this article was to call the attention of owners of pine timber to the serious character of the trouble, and to urge them to make every possible effort to utilize the dead and dying timber before it was rendered worthless by the wood boring insects which atlack it the same or the following year after the trees die. While this may have had the effect of preventing the sale of some of the affected timber to innocent purchasers, and in this manner proved obnoxious to a few own- 
ers of dead timber, I am confident that the good arising from this frank statement of facts more than overbalanced any harm that came from it.

THE DYING PINE FOREST.

(Published in Wheeling Daily Register May 19, 1892, and in other W. Va. and $V$ a. papers.)

The widespread ana universal death of pine timber, which has been going on in portions of Hampshire, Hardy, Grant, Pendleton and Mineral counties, West Virginia; Bath, Highland, Augusta and Rockingham counties, Virginia, and also in portions of Maryland during the past two years, has been a very remarkable occurrence, exciting much curiosity and comment as to the probable cause. At the present time, the conditions, in the best pine timbered districts in the affected region, is really alarming, for if the trouble contimues, there will not be a living pine of any value in all that pine timbered portion of West Virginia and Virginia lying between the Allegheny Range proper and the Blue Ridge, and extending at least 120 miles southwest from Maryland, a total area possibly of six thousand square miles.

Between the $2 \mathrm{~d}$ and 7 th of this month, (May 1892,) I traveled about 140 miles through the counties of Hampshire, Hardy, Grant, and Pendleton for the purpose of observing the condition of the pine forests, and to investigate the cause of the trouble. I examined large numbers of the healthy, dying and dead trees, and my corclusious are that their death is caused primarily by the attack of a single species of insect, a bark beetle, the scientific name of which is Dendroctonus frontalis, which has, under favorable conditions increased to such great numbers that they attack perfectly healthy trees, and by their operations in and under the bark on the upper portion of the trees, produce a diseased condition, which attracts hundreds of other species to their assistance, and the death and destruction of the trees so attacked is inevitable.

The trouble begins in a healthy forest by one or two insolated trees or groups dying the first year. Countless millions of little beetles breed in these infested trees and emerge through the bark to attack other heaithy ones, which die the next year in great numbers, and by the third year, as shown in the southern portion of Pendleton County, the entire forest is killed for miles around. The best and healthiest yellow and pitch pine trees seem to be attacked first; after which, the trouble extends to the scrub pine, and later to the white pine.

Had we known of the trouble when it commenced, possibly the spread could have been prevented, to some extent, by the use of parasites or natural enemies of the destructive insect; or valuable tracts of timber might have been saved by cutting and burning the first infested. At the present time, however, it is too late to think of recommending or attempting to apply a remedy. The trouble has extended far beyond all human control, and nearly all of the valuable timber is either dead or dying. There is one thing that can be done, however, to prevent a total loss of the millions of dollars worth of timber now dying ; that is, for the owners to make an earnest effort to convert all the best trees into lumber or square timber within a year after they die. The lumber can be stacked up and saved for any length of time, while the standing trees would be worthless the second year after they die, owing to the large boring grubs and decay.

While the destruction of the pine timber is a deplorable fact, it is only one of the many resources of the region mentioned. There are yet re- 
maining, in comparatively good health and vigor, immense forests of white and chestnut oak and other valuable timber; the bark of the chestnut oak at the present time, being a very important item of revenue. The region embraces some of the richest and most beantiful valleys in the world ; and a large portion of highlands now covered with dead pine, if cleared and sown to grass, and stocked with sheep, would, if properly managed, add greatly to the wealth and prosperity of the now unfortunate owners.

The great mortality among the pine, spruce and locust timber of the state within the last ten years is a sad example of the millions of dollars worth of property which may be desiroyed by some of our smallest forms of insects. The importance, therefore, of conducting investigations with a view of preventing like devastations in the future, can not be doubted. It has been a neglected field of study by Entomologists mainly on account of its vastness ; hence, there is $\mathrm{much}$ to be learned by investigation and experiments.

We feel a deep interest in the preservation of our forest ; and we believe that much loss may be prevented by prompt action in utilizing some of Nature's methods; one of which,is the introduction of beneficial insects. To be successful in this as in the application of other prevenatives and remedies, we must be notified of the first indications of trouble, and have the unstinted co-operation, and assistance of the owners of the affected timber.

May, 1892.

FURTHER INVESTIGATIONS.

On June 16th, 1892,.I started on another tour of investigation into the spruce forests, which were also reported to be affected in a similar manuer as the pine. Proceeding to Hendricks, in Tucker county, where 1 procured horses and guides, I entered the spruce wilderness by the way of the Dry Fork of Cheat river, and its tributary, Gandy creek. During this investigation which coutinued until July 6 th, I passed through portions of the extensive spruce forests in Tucker, Randolph, Pendleton, Greenbrier and Pocahontas counties, and the white pine forests in Greenbrier and Pocahontas counties along the Greenbrier river, returning to Morgantown via. the Chesapeake \& Ohio, the Ohio River and the Baltimore \& Ohio railroads, through the sonthern and western section of the pine and hardwood area. In all these forests I found the timber dying in greater or less quantities, the trouble has aparently just commenced in the spruce, and had not extended beyond isolated groups each composed of a few hundred trees or less scattered over the spruce area (See previous chapter, spruce investigations). In the white pine forests in Pocahontas and Greenbrier counties the conditions were of a more serious character, a larger 
per cent. of the forest timber having died, or was then dying. There was, however a large amount of white pine which had not been invaded.

In all of the dead and dying spruce and pine trees examined during this investigation, the same conditions were found as those observed in the pine forests of Hampshire, Hardy and Pendleton Counties, during the previous May, and the.conclusions arrived at then were abundantly verified; namely, that the death of the trees was the result of a primary attack by the destructive pine bark beetle, which richly deserves the common name I had given it, although it had proven to be destructive to the spruce as well.

The following extracts from an article prepared by the writer and published in Science, Vol. XX, 1892, p. 64., soon after my return from the investigation just mentioned, will give some additional information with reference to the habits of this destructive bark beetle and its principle allies, as had been determined up to the date the article was written.

\section{EXTRACT FROM ARTICLE IN SCIENCE.}

* * It has been claimed that Scolytids never attack healthy, living trees. We acknowledge that as a rule the different species of this family have a preference for unhealthy trees or those which have been broken by storm or felled by the ax, but in this species (Dendroctonus frontalis) we certainly have an exception to the rule. From the abundant evidence I have obtained during the extended and careful investigation, I am convinced that the death of large and small, vigorous trees of five species of pine and of the black spruce was caused primarily by the attack of this insect. In fact, this species seems to have a preference for the green bark on the living pine and spruce which they invade.

As Entomoligist of this Station, I have conducted some investigations regarding the ravages of this beetle, and, since May $2 \mathrm{~d}$ of this year, have traveled about 340 miles through some of the principal regions of the State where the pine and spruce are most common. The species of pine observed were the White Pine (Pinus alba) - [P. strobus] The Yellow Pine $(P$. echinata), the Pitch Pine ( $P$. rigida), the Table Mountain Pine, $(P$. pungens), and the Common Scrub Pine (P. inops)-(Virginiana) and also the Black Spruce (Picea mariana) which is a common and valuable tree on some 500,000 acres of the higher mountains and tablelands of this State.

Trees varying from five inches in diameter to the largest, finest specimens of the five species of pine mentioned, and of the black spruce, were found dying in different sections from a cause which it was my duty to investigate. A large number of the dead, dying, and living trees were felled and examined. Every part of the trees from the roots near the surface to the terminal twigs and leaves was carefuliy searched for possible causes of their unhealthy condition. The trees in the bast condition to examine were thoș ou which the leaves ware yet green, bat from thair 
general appearance indicated that they had been attacked by the characteristic trouble which was shown in a few yellow leaves at the tops. The roots of such trees were found in a perfectly healthy condition for some distance beneath the surface; the bark on the trunks from a distanc of from five to fifteen feet from the base was green, full of sap, and apparently healthy; the leaves were almost free from insect attack or disease, in no case was there sufficient attack of this nature to indicate even a slight injury; the bark, however, at a point about two-thirds up from the base of the tree, was found in every case to be infested by Dendroctonus frontalis in sufficient numbers to kill all the bark for some distance above that point, and in this bark fully developed beetles and pupae were fonnd on May 5th, thus indicating that the eggs must have been deposited in the bark the previous summer or fall. All of the characteristic dead and dying pine and spruce trees examined showed abundant evidence that they had been invaded while yet living by this bark beetle.

It would seem that the turpentine escaping into the burrows made by the beetles in the living bark would render the conditions unfavorable for the progress of their work. They have, however, the power of removing it from their burrows, and they manipulate the sticky resinous substance with seemingly as much ease and in a like manner as the crawfish does the clay it piles up around its burrow. Often a half teaspoonful of the pitch will be found massed about the entrance to the burrows made by the beetle. They push the turpentine out through a hole kept open in the pitchy, adhesive mass. I have observed them backing out from the entrance, shoving behind them a quantity of turpentine, and at the same time they would be completely enveloped by it.

Trees invaded by these beetles the previous fall may remain green un til spring when they are usually attacked by the large Dendroctonus terebrans, Hylurgops glabratus and Tomicus calligraphus, the two former at the base of the tree, the latter in the green bark above. They are in turn followed by numerous species of bark and timber beetles nntil the invaded trees may be, as I have found, the hosts of at least twenty-five species of scolytids coming like reinforcements to the aid of $D$ frontalis to make doubly sure of the death of the invaded trees. Later on, these Scolytids are followed by insects belonging to other families until a dead or dying tree may be the host of hundreds of species and millions of examples, breeding in and feeding upon every part of the tree from the base to the terminal twigs, rendering it worthless for lumber within a year after it dies.

It will be seen that Dendroctonus frontalis may be the primary cause of not only the death of the trees but of their rapid decay.

West Va. Agricultural Experiment Station, Morgantown, West Va., July 20,1892 .

\section{THE CONSIDERATION OF REMEDIES.}

As stated in a subsequent article to Insect Life, a copy o1 which will be found further on in this report, the possibility of applying a remedy against the rapidly spreading ravages of the destructive bark beetle seemed out of the question, but when it was found in June, 1892, that the insects had just commenced their attack upon the extensive forests of black spruce and white pine, it indicated that possibly some method could be 
discovered by which the then healhty and more valuable portions of these forests could in a measure, be protected.

The methods of cutting and burning the infested trees, or removing the bark, as is practiced in European forests against like troubles, was, owing to the existing conditions in our forests, impossible, or at least impractable.

THE IMPORTATION OF NATURAL ENEMIES OF BARK BEETLES CONSIDERED.

Upon my finding, early in 1891, that the European fruit bark beetle, Scolytus rugulosus, was quite common and destructive to fruit trees in varions sections of the State, which, in addition to the devastations previously observed in the spruce forests, which was believed to be the work of bark beetles, I realized that we had among the introduced and native bark beetles, some of the most destructive forest and fruit tree pests known, and that in the study of their habits, life histories, natural enemies, and methods of combatting them, was a great problem demanding special attention. In the consideration of remedies at that time, it occurred to me that if some parasitic and predaceous enemies of bark beetles could be imported from Europe, that possibly they would render valuable service in keeping our destructive species within proper bounds, since it was then thought (Bulletin 17, p. 99,) as subsequent observations demonstrated, that the bark beetles can kill trees only when occuring in excessivive numbers, and that if for any cause the excess is reduced, their destructive powers are ended, so far as attacking and killing trees is concerned, and that anything which will prevent their excessive multiplication, will, at the same time, prevent further death of trees from their attack. In the following July, when I found that the pine timber was dying evidently from the attack of bark beetles, I gave the subject of importation of parasites especial attention, as the following correspondence and accounts of subsequent events will show. Through the kindness of the Government Entomol ogist, Dr. C. V. Riley, I was, in June, 1891, placed in correspondence with one of the Emperor's chief Oberforesters, W. 
Eichhoff of Strassburg, Germany, a renowned specialist in the study of European bark beetles (Scolytidae), who desired to obtain a large series of specimens of bark beetles from this country for study. After sending him specimens of all the species I had then collected, which he kindly examined and identified for me, I made the following request which was the first active measure taken towards the contemplated importation of parasites, as a means of controlling distructive bark beetles.

Extract from letter to Mr. Eichhoff, dated Oct. 12th, 1891:

"I regard to a further sending from you I would say that if after you have named for me the beetles in both of my sendings, you desire to send me auy more, I would be pleased to have some specimens of insects which are known to destroy your most injurious species of Scolytid; in fact, I would like to arrange to have you select and send me live pupae of some of the parasites of your scolytidae, which you think might be of benefit to us in destroying some of our injurious species here:

Parasites which would attack Scolytus rugulosus, Polygraphus rufipennis, Dendroctonus terebrans, or $D$. frontalis, might prove of great benetit to us, if we can succeed in propagating them."

Mr. Eichhoff, in reply to this letter, kindly sent me a large number of pinned specimens of parasitic and predaceous insect enemies of European Scolytids.

THE PINE AND SPRUCE THREATENED WITI TOTAL DESTRUCTION.

After making a thorough investigation of the spruce and white pine forests in June and $\mathrm{July}, 1892$, as previously mentioned, and having ascertained beyond all question that the true cause of the trouble was due to the attack of the pine bark beetle, which was materially aided by numerons other species of bark beetles, I realized that the early and total destruction of the pine and spruce timber of the Stale, as well as of the eastern and southern United States, was not only possible but probable, if the progress of the invasion was not in some way abated or checked.

Finding that the trouble had just commenced in the spruce, and that there were large bodies of healthy white pine which had not been invaded, I was led to believe that the previously contemplated experiment of introducing natural enemies of bark beetles from Europe was worthy of a trial, and that possibly such enemies, if successfully located around the borders 
of the healthy portions of the forests, would attack the Dendroctonus and its principal allies, and thus, in co-operation with other native natural enemies of the bark beetles, serve to reduce the excess and thus aid in checking the trouble. I therefore returned to the Station on July 6 th, 1892, determined to take active measures for securing a sufficient number of European enemies of Scolytids with which to conduct the contemplated experiment. After consulting with the Director of the Experiment Station, the following brief report of the conditions as I had observed them, and recommendations with reference to an experiment of introducing natural enemies from Europe was sent out under the head of "Special Correspondence to Uwners of Spruce and White Pine Timber" to all of the principal companies owning pine and spruce timber in the State, so far as addresses could be obtained.

Following is a copy of this report :

SPECIAL CORRESPONDENCE TO OWNERS OF SPRUCE AND WHITE PINE

TIMBER IN W. VA.

\section{(Circular Letter.)}

As Entomologist of the West Virginia Experiment Station, I have recently conducted extensive investigations in the pine and spruce forests of the eastern portion of the State, for the purpose of ascertaining the extent and cause of the unhealthy condition of the pine timber.

I have just now returned from the second investigation of the trouble, and have found it to be of such serious consequence to the State, and especially to those having large investments in our spruce and white pine, that I feel it my duty to inform the principle owners of the conditions as I have observed them from a scientific standpoint, trusting that the information may aid you in your deliberations regarding the matter.

EXTENT AND DISTRIBUTION OF THE TROUBLE.

From personal observation, I found the unhealthy condition of the scrub, yellow, pitch, table mountain and white pine to extend from the Maryland line on the north, through Mineral, Hampshire, Hardy, Grant, Pendleton, Pocahontas and Greenbrier counties to Summers and Raleigh counties on the south. From inquiry and correspondence, I learn that the trouble also extends through the western part of Virginia for about the same distance, including an area of possibly 10,000 square miles in both States; I should think $10 \%$ of the white pine and $75 \%$ of all other species of pine found growing in this region, is either dead or dying. In the spruce, "yew pine," from near Hendricks on the West Virginia Central, through Tucker, Randolph and Pocahontas counties to Traveler's Repose, the timber is just commencing to die in groups of from a few trees to possibly a thousand; these groups being scattered through. the forest, most common near the infested pine districts of Pendleton county. The 
dying trees on about one hundred to onehundred and fifty thousand acres, as observed during a six days' journey through the forest between the point mentioned, would be about one per cent., possibly not over one-half of one per cent.

\section{CAUSE OF THE TROUBLE.}

The primary cause of the unhealthy condition of the pine and spruce. I have found to be the result of attacks of a single species of insect known to science as Dendroctonus frontalis, to which we will give the common name of destructive pine bark beetle. Heretofore this species has been a rare insect, and but very little was known of its habits and history. During the two investigations in the region mentioned, I have carefully examined a large number of dead, dying and green trees of all the species of pine and of black spruce. In every case I have found abundant evidence that the insect mentioned was the cause of the trouble, the trees having evidently been in a healthy condition at the time they were invaded by the beetle.

The destructive pine bark beetle is a small black, hard-shelled "bug" one-eighth of an inch long. It is found most common in the infested trees under the bark on the main trunks at a point about two-thirds up from their base near the first branches or forks, this being the point where they make their first attack. The beetles evidently attack the tree soon after the sap goes down in August, when they bore through the bark to the outer sapwood, extending their galleries or egg chambers twelve to fourteen inches through the inner portion of the bark and just touching the sapwood. In these galleries, they deposit great numbers of èggs, which soon hatch into minute white grubs which proceed to bore through and feed upon the tender inner bark until they are full grown, (about half as large as rice grains.) They then enter the outer or dry bark where they change to the beetle or perfect form. They probably pass the winter in all stages of growth, from newly hatched to full grown grubs, and in the spring, they change to the beetles and emerge from the bark, leaving it pierced with millions of small round holes. The beetles which emerge in the spring breed in the green portions of the bark on the same irees from which they emerge, and also in trees injured but not killed by the attack of the insect the previous fall. This second brood matures and emerges in time to attack the trees in August and during the fall, as at first.

Some of the earliest trees attacked may die during the fall and early winter, but by far the larger portion of them die the following spring when, on account of the unhealthy condition brought about as above stated, hundreds of other species of insects are attracted to them and their death is rapidly hastened.

The yellow, pitch and white pine are rapidly rendered worthless after they commence to die, both from the blue condition, probably caused by the souring of the sap, and by numerous insects boring in the wood; the one which is especially destructive being what is known as the "sawyer." This destructive borer is hatched from eggs deposited in the bark of the affected trees by a large, gray, long-horned beetle. The grubs feed for a time under the bark, and as they attain their growth, they enter the wood, often penetrating the tree to its heart. When they are common in a tree they soon render it worthless for lumber. This large borer also attacks the spruce trees and logs, but seldom cáuses much damage.

The spruce, on account of its thin sap wood, is not so liable to injury from "bluing" or from wood-boring insects, may remain sound and, all except the sapwood be profitably worked into lumber and pulp for a number of years after they die, varying from three to five or six years. 


\section{POSSIBLE METHOD OF CHECKING THE TROUBLE.}

The fact is that the trouble has now extended over an area in Virginia and West Virginia of at least 10,000 square miles during the last three years, killing possibly $75 \%$ of all the large pine except the white pine, making the trouble appear to be beyond control, at least as far as the yellow, pitch and scrub pine is concerned.

In regard to the spruce and white pine, they are the last to be attacked by this destroying beetle, thus indicating that they are naturally more capable of resisting the attack.

Therefore, any natural or artificial means that would reduce the numbers of the beetles or prevent their increase would possibly check the trouble entirely in the spruce and white pine.

It is only through the attack of great numbers of these beetles that they are capable of killing the trees, therefore, any method which would even slightly reduce their numbers might be the turning point leading to their natural death from lack of proper conditions for their multiplication. It seems necessary that they kill the trees in which they breed, and, if at any time there is not enough of them to kill the trees, this will end their destructive existence.

The only apparent way to accomplish the above end is through the natural appearance or artificial introduction of some disease or insect which will prey upon the destructive beetle and thus reduce its number's.

A species of disease has been discovered by us which is killing them to some extent in the pine, but the beetle seems to have few insect enemies in the country.

SIMILAR TROUBLES CONTROLLED BY THE NATURAL APPEARANCE AND ARTIFI-

\section{CIAL INTRODUCTION OF INSECTS.}

A similar trouble in the spruce between 1882 and 1889 , when at least $10 \%$ of the 500,000 acres of spruce in the State was evidently killed by the spruce bark beetle (Polygraphus rufipennis) was, I have every reason to believe, reduced beyond ics destructive power by the natural appearance and increase of at least six species of insects which feed upon it.

It is a demonstrated fact that the introduction of a species of the "Lady Bug" from Australia for the purpose of feeding on and destroying a destructive orange insect in California resulted in the almost total destruction of the orange insect and a saving of millions of dollars to the orange grower's of the State.

It has therefore seemed to me very possible that if we could introduce certain insects that would feed upon the destructive pine bark beetle, a great saving might be effected at a comparative light expense. As I know of no insect in this country which would likely be effectual, it occurred to me that some foreign species known to feed on beetles similar to this one if introduced might have the desired effect. Upon my return from the first investigation in May. I wrote to my correspondent in Strassburg, Germany, who is one of the best informed entomologists, and the Emperor's overseer of the forest of Elsass, asking him if he would procure and send me certain species which were known to be very beneficial to their forests. His prompt reply which I have just received, informs me that old age and poor health would prevent him from aiding me in the experiment, but referred me to another party in Saxony who would doubtless give me the desired information and aid.

I shall make every effort in my power to secure as many friendly insects as possible from Europe, which should arrive here in time for them to be introduced into the forest by the middle of August, or first of September. I shall communicate with the party mentioned, by cablegram in order 
that no time may be lost, and if I find that the desired species can be procured, it may be necessary to make a special trip to Germany and France for the purpose of making certain the securing and safe transportation of a large number and variety of such insects as might be useful to us.

The law under which we are employed will not, however, allow the expenditure of any large amount of money upon any one department to the detriment of others; therefore if the lumber interests of the State will agree to share the necessary expense of securing such insects, it may be speedily accomplished.

Signed,

A. D. Hopkins,

Morgantown, W. Va., July 11, 1892.

Entomologist, West Va. Agr.

Experiment Station.

Each copy of the above report was accompanied by the following letter, dated July 12th, 1892:

DEAR SIR :

"Enclosed you will find a special condensed report of my investigations in the pine and spruce forests of this State, which I trust will be of interest and value to you.

The only remedy I can think of to prevent the spread of the trouble in the spruce and white pine, is set forth in the closing paragraph."

Prompt replies to this communication were received from the following persons who represented the principal owners of spruce and white pine in the State:

Hon. J. N. Camden, President W. Va. \& Pittsburg R. R. Co.; Mr. E. L. Tunis, Gen'l Manager Condon Lane Buom \& Lumber Co.; and Robert R. Henderson, President Oumberland Lumber Co.; all of whom expressed a willingness to contribute to the expenses of carrying on the experiment. In the meantime, I had received a reply to my letter to Oberforester Eichhoff. The following extracts from this letter may be of interest:

CORRESPONDENCE WITH ENTOMOLOGISTS IN GERMANY.

Letter from Oberforester Eichhoff.

\author{
Strassburg, Elsass, \\ Aarstaden, No. 3, June 26, 1892.$\}$
}

Most HoNORED SIR:

I have received both of your last letters but through continued sickness have been prevented from writing to you sooner.

I cannot now give you my personal co-operation in furthering your scheme of importing Clerns formicarius to America, however, willing I might be to assist in the matter. You will understand this when I herewith inform you that within a very short time I reach my seventieth birthday. $A$ man so old who does not possess the necessary activity, should not engage in such investigations as your proposition clemands. When I further communicate to you that I am not generally able to leave my house at all on foot, and in a carriage only during favorable weather, and, that within my house can only, with pain and trouble, go from one room to another; you will understand what I have said above. I also feel that I have but a short time yet to live, therefore, I hope you will endeavor to have some other person assisc in the undertaking.

However, I might commend to you for this undertaking Mr. Director C. 
Schaufuss, of the Museum of Meissen (Kingdom of Saxony) and transfer the request to him. I believe he will be the one to give best advice. He possesses abundant insect collectors throughout the country and would also make entomolgical exchanges with you. * * *

* * * How the second of your bark beetles ( $D$. frontalis) may be suppressed I do not know, because the life history of this insect is not entirely known to me. I possess, all told, only two specimens of this beetle, one, if I mistake not, from you and one from the lately deceased Dr. C. A. Don of Stitten.

In conclusion, because of my sickness, I once more ask an apology for this delayed answer.

Now farewell, with highest esteem besides,

Your most devoted

Еiсннонт.

Upon receipt of Mr. Eickhhoff's letter I at once wrote to Director Schaufuss as follows:

Oberforester IV. Eichhoff, of Strassburg, has referred me to you in a recent letter, saying that you would be one who could help me in a contemplated experiment in introduciug some live European insects to this country. * * * As Entomologist of this station, I am anxious to try the experiment of importing somelivespecimens of Clerus formicarius and such other Clerids which in your judgment might feed upon $D$. frontalis.

If you will kindly aid in the experiment, I will give you full credit for your share of the transaction and pay such reasonable expenses as may be necessary in obtaining and sending the specimens. If you are willing to do so, please answer yes, or no by cablegram the following questions:

1st. Do you know of any scolytid eating insect in Germany, France or Norway which could be obtained in numbers in the month of August?

2d. Could you undertake to collect and send me live adults or pupae, I paying cost.

3d. I can and will, if necessary, visit Europe for the purpose of collecting these live Clerids, etc. IVill it be possible for you to direct me where I can collect them in August?",

In reply to this letter I received a cablegram stating, "2d, YES," which indicated to me that the desired insects were to be had, and realizing that if they were te be introduced into the forests here during the fall of 1892 , there was no time for negotiating in Germany by correspondence, it was decided that in order to secure as many examples as possible and insure the safe importation, it would be necessary for me to personally superintend the collecting and shipping of the first lot, and to engage collections and give instructions with reference to subsequent shipments, whereupon the following letter was addressed to the parties who had expressed a willingness to aid in the venture:

\section{LETTER TO TIMBER COMPANIES.}

"I have just received a cablegram from my correspondent Entomolo" gist in Saxony indicating that the desired beneficial species of insects which we wish to import for the purpose mentioned in our previous cor- 
respondence, are now to be had there. If we are to procure them, it will be necessary for me to start immediately, and I am preparing to. leave here for that purpose on the 15 th inst. In addition to the other two firms of whom I have advised you, the St. Lawrence Boom and I'f'g Co. signify their perfect willingness to pay their proportion of the expenses.' If, therefore, no others come in, your proportion of the estimated expenses will be a fourth share of $\$ 600$ (the estimated expense over and above the moneys available out of our funds.) If others should come in, the pro rata will be correspondingly reduced for all. If your firm still desires to share in this venture please remit your portion as stated, to Dr. John A. Myers, Director. Should my expenses prove less than the amount contributed we will reimburse all pro rata.

Calling your attention to the earliness of the date necessary for my departure, which depends upon the above contributions. I remain," * *

AMOUNTS CONTRIBUTED BY OWNERS OF TIMBER.

In reply to this letter the following named companies promptly forwarded the amount indicated:

The Condon-Lane Boom and Lumber Co., through E. L.

Tunis, Bretz. W: Va.................... $\$ 150$

The W. Va. \& Pittsburgh R. R. Co., through J. N. Cam-

den, its President.........................

The St. Lawrence Boom and M'f'g Co., Ronceverte, W.

Va., through E. C. Best........................

The Cumberland Lumber Co., Cumberland, Md., through

Robert R. Henderson. Pres....................

Contributions were subsequently received as follows:

E. A. Monaghan, Lock Haven, Pa. ... . . . . . . . . . $\quad 75$

J. R. Beaty \& Co., Crow, W. Va. ............... 75

Making a total of $\$ 750$, to which amount the Station Committee authorized the addition of $\$ 150$ from the Station funds, wherefore the following letter of instructions was handed to me by the Director of the Station :

\section{LETTER OF INSTRUCTIONS.}

Mr. A. D. Hopkins,

Entomologist:

"At a meeting of the Station Committee of the Board of Regents of the West Virginia University held August 11th, 1892, at the Experiment. Station, the following orders were passed:

Ordered 1st." "That A. D. Hopkins, Entomologist of the W. Va. Agricultural Experiment Station be directed to proceed to Europe in the quest of such insect parasites as in his judgment will, when introduced into the State, check the destruction of our forests by the insect pest at present causing such widespread injury to our pine and spruce timber.

$2 d$. That to assist in paying the expenses of this trip, $\$ 150$ of the funds of the Station be devoted to the payment of the cost of the experiment, 
and that so much of the funds contributed by the respective lumber companies as may not be expended in the work be returned to them pro rata, should there be any remaining after the experiment has been made.

3d. Ordered, that those companies who have, or will contribute their pro rata to the expenses of the experiment shall be first considered in the distribution of these insect parasites, and that the bulk of the im. ported insects shall be distributed upon the property of these several companies.

In accordance with these orders you will please make arrangements as soon as possible to proceed to Europe to carry out the objects of the above orders. Large latitude is given you in regard to the selection of points to be visited, the principal object of the trip being to accomplish successful results. The neceesary funds not exceeding $\$ 600$ will be placed subject to your order to enable you to meet the legitimate expenses of the trip, and to employ such help in Europe and to purchase such cases, apparatus, etc., as may be necessary for you to successfully carry out the objects of the expedition. It is not presumed that the time required for you to accomplish the objects of the trip will be more than six to eight weeks, and the necessary leave of absence from the Station is hereby granted.

JoHN A. MYers, Director.

\section{ACCOUNT OF MISSION TO EUROPE.}

Upon the receipt of the Director's instructions the necessary preparations for the journey were made and I left Morgantown on August 16th, sailed from New York on the 17th, and arrived in Strassburg, Germany, on the 27th, via Liverpool, London, New Haven, Dieppe, and Paris. The next day after arriving in Strassburg, I called on Oberforester W. Eichhoff at his home, and obtained from him valuable information and important official documents, by means of which I was to have both unrestricted access to the Emperor's forests, and the co-operation of the forest officials in furthering the objects of the mission. This, unexpected and exceedingly kind and thoughtful provision for the undelayed prosecution of the work was most encouraging, but Mr. Eichholf's expressions of doubt as to the possibilities of finding the desired insects in any quanity, and especially in the desired condition for successful transportation to America, was equally discouraging. I told him, that I especially desired to find a section in the pine and spruce forests where the trees had heen recently injured by storms or other causes, and I was pleased to learn from him of two localities where the desired conditions would probably be found, one in the extensive forests of Pinus sylevstris, near Hagenau, in Elsass, the other in the white spruce forests of the Vosges 
mountains, near Aberschwiller in Loraine, (Lothringen), I felt confident from my knowledge of the habits of American examples of the family of insects to which the most desired species belong, that here I would meet with some success.

INVESTIGATIONS NEAR HAGENAU.

\section{The Desired Beneficial Insect Found.}

The next morning, August 28th, I proceeded to Hagenau where I arrived at $11 \mathrm{~A}$. M. and at once went to the office of Oberforester Stralimeyer, and informed him of the object of my mission, expressing at the same time, a desire to visit a section of the forest indicated by Oberforester Eichhoff. Oberforester Strahmeyer manifested his interest in the undertaking and a desire to give encouragement and assistance by detailing his son and a forest official to accompany me. After lunch, we engaged a cab and proceeded into the forest which was entered a few. miles out of the city limits. We had only proceeded a few hundred yards along the street which led into it when I observed some trees which had been broken by snow during the previous winter. Upon making an examination of these trees I found that the bark was infested with bark beetles and the first cut I made into the outer bark revealed a larva of the desired insect (Clerus formicarius.) Further search revealed an adult, and in a short time we were engaged in collecting all stages of the insect. Even the driver impelled by our enthusiasm, armed with his jack knife, proceeded to dig into the bark for the "kafer" (beetle.) Within two or three hours we had secured 49 examples of the Clerid-12 adults, 35 larvae and 2 pupae. In addition to these, 50 cocoons and 2 adults of a Braconid parasite of the bark beetles were taken. After making some further observations as to suitable localities in which to prosecute our search on the morrow, we returned to Hagenau well pleased with the results of the first few hours' work on my second day in Germany.

The next morning we started out to make a general survey of that portion of the forest in which the broken timber occur- 
red. We succeeded in adding 50 more examples to the collection, and in finding a nuinber of sections of the forest where the insects occurred in great numbers, but owing to my supply of vials having been exhausted from the necessity of placing but a single Clerid in each ${ }^{1}$ no further collections could be made at that time. Therefore, after securing a number of good photographs of some interesting features of the forest, (some of which are reproduced, see Figs. XXXVI, XXXVII

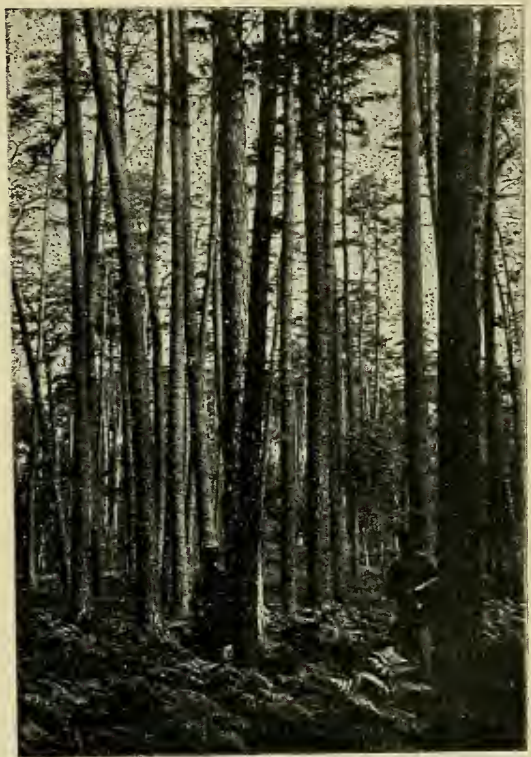

Fig. XXXVI.-View in cultivated forest of pinus sylvestris near Hagenau, Germany.

and XLIV), we returned to iny hotel at Hagenau, where I was entertained during the evening by Oberforester Strahmeyer in the hearty manner characteristic of German hospitality.

The next day after an exceedingly interesting exploration of the forest on the east of the city, accompanied by Oberforester Strahmeyer and his son, I returned to Strassburg, and in the evening called on Oberforester Eichhoff, to report my success.

RETURN TO STRASSBURG.

After dinner with Mr. Eichboff and spending a most enjoyable and profitable evening in the company of this renowned and classic specialist in the study of Scolytidae, and in looking over his elaborate collection of bark and timber beetles and their work, I returned to my hotel and made preparations to

1 It was found that if more than one adult or larva were placed together in a bottle or box, that they would attack each other and one or both would soon die from the injury, or that a strong one would completely devour weaker ones placed within its reach. 
go on to Dresden in the morning where I hoped to be able

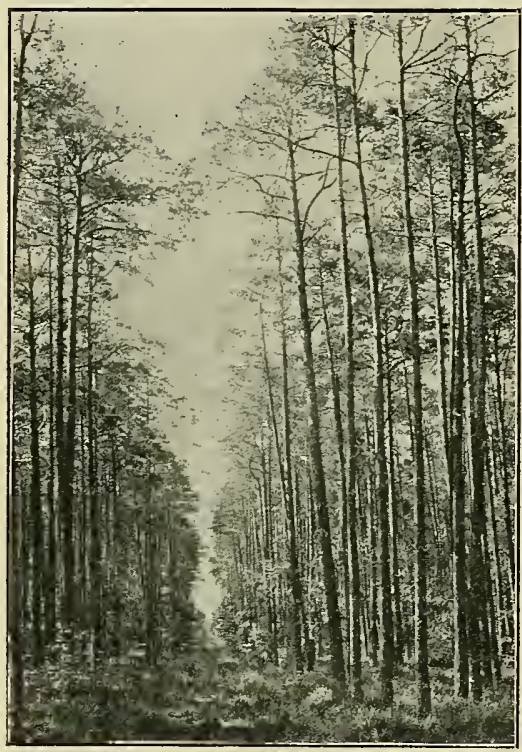

Fig. XXXVII.-Street in cultivated pine forest: near Hagenau, Germany. to secure a sufficient and much need supply of small vials into which the Olerids could be placed as collected.

IN VESTIGATIONS IN SAXONY.

I left Strassburg at noon on Sept. 1st and arrived in Dresden, saxony, via Frankfort and Leipzig in the evening of the same day. Here I obtained the desired collecting material, and the next day proceeded to Meissen, where $I$ arrived at 3 P. M., Sept. 2 l. I soon found Director Schaufuss at his museum, and we made arrangements to

make an excursion into the forests the next day. In company with Mr. Schaufuss and one of the artists from the King's Porcelain Works, who is also an Entomologist, we made an early start on the morning of Sept. 3d, and entered the King's forest near Moritzburg, where, after obtaining permission from the authorities, we commenced a vigorous search for Clerids. No broken or injured trees occurred here as in the Hagenau forest, but examples of pine trees of various sizes were found which had died within the last twelve months. In the bark of the first one of these trees examined, both larvae and adults of the desired insect were found. The bark had been removed from the lower portion of the trunks of the greater number of standing dead trees for the purpose of destroying the bark beetles. Therefore, it was only $y_{j}^{*}$ here the work had not been thorough, and a purtion of the bark had been lefton the base of the trunk that we were 
enabled to find the clerids which invariably make their pupa cases in the outer soft bark, and as a rule, in that at the base of the tree. Although but few trees were found in the proper condition for Clerids, we succeeded during the day in collecting 53 larvae, 2 pupae and 2 adults. So common were they in the bark of some trees that a dozen or more were taken from pieces of bark five or six inches square. If the bark had not been removed from the trees, we would certainly have secured several hundred exanples. It was evident to me that if the practice of removing the bark from the base of the dead and dying trees was for the purpose of destroying the bark beetles, more harm than good had probably resulted, since the bark beetles appeared to have occurred in the greatest num. bers on the upper part of the trunk where the bark had not been removed; while the beneficial Clerid had either been destroyed in the bark, which had been taken from the base of the tree and burned, or they had been deprived of this, their favorite place for pupating.

We arrived at Moritzburg in the erening, and after dining at the hotel in the village and visiting the ancient "Jagdschloss" or king's hunting castle, we returned to Meissen, where we arrived at 11 p. m., much fatigued from our long tramp through the forest. The next day being Sunday, I was entertained by Mr. Schaufuss at his home,

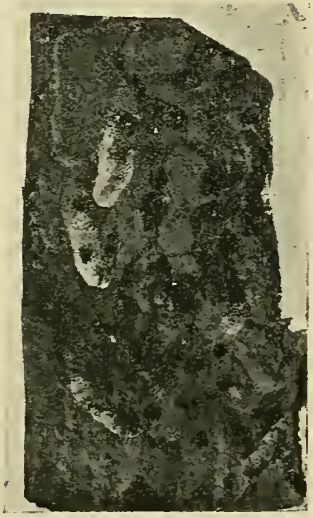

Fig. XXXVIII.-Six pupa cases of the European bark beetle destroyer in a piece of bark $1 \frac{1 / 2}{2} 2 \frac{1}{2}$ in. and with him visited points of interest, including the Agricultural Experiment School, which corresponds somewhat to our Experiment Stations.

RETURN TO STRASSBURG THROUGH BAVERA AND BADEN-BADEN.

On Monday I returned to Dresden in company with $\mathrm{Mr}$. Schaufuss. After visiting many points of interest and arranging with Mr. Schaufuss to procure as many examples of the 
Clerid as possible within the next three days, and forward them to me at Strassburg, I left Dresden on the night train for Strassburg, going via Munich, Constance, and the Schwarts Wald railroad, through the Bavarian and Black Forests. Some striking features of the forest area of Bavaria, as viewed from the train the next day were the prevalence of spruce, evidently the Norway spruce (Abies excelsa), and the evidence of a most thoroughly executed forestry policy. A feature of special interest was the encouragement of insectiverous birds by providing for them small and neat nesting boxes in the trees. These were observed by the thousands as we passed through the forest. The methods adopted for the control of the nonne moth, which is the great enemy of the Bavarian conifers, was another interesting feature. Apparently every tree, large and small, over extensive areas in some sections, has a belt of the outer bark removed from the trunk a few feet above the base, and the smooth surface covered with a black, sticky substance to prevent the caterpillars from ascending the trees.

The condition in the great Black Forest in the mountains of Baden-Baden were also of especial interest, as viewed from the car window, both in its wide expanse, and the evident care bestowed upon it, both to preserve the timber and the land on the precipitous slopes.

Upon my arrival in Strassburg on Sept. 7th, I received my first letters from home, informing me that great alarm was felt for my safety because of the exaggerated accounts in the American papers of the cholera epidemic in Germany, the existence of which had not given me much concern on my own account, but the possibility of my collection of Clerids being destroyed at the quarantine stations by the severe fumigation that all packages from Germany were subjected to, caused me considerable worry.

INVESTIGATIONS CONTINUED. NEAR HAGENAU.

After a day's rest in Strassburg, I proceeded to Hagenau on the morning of the 8 th, arriving there at $8 \mathrm{a} . \mathrm{m}$. After calling on Oberforester Strahmeyer, I engaged a cab, and accompanied 
by the Oberforester's first assistant, proceeded directly to the forests where we arrived at 9:15 a. m., and at once commenced a vigorous seach for Clerids. Although it rained incessantly and very hard, we were so successful that by 11:40 a. m., 187 living examples of the Clerids had been secured, but owing to the rain we were compelled to abandon the work. We then returned to Hagenau, and after Junch I called on Oberforester strabmeyer and obtained from his son, Mr. H. Strahmeyer, 180 examples of the Clerids which he had collected for me during my absence in the Kingdom of Saxony, and after engaging him to secure as many more as possible, within the next two days, I left Hagenan by rail for Aberschwiller in Loraine.

INVESTIGATIONS IN THE VOSGES MOUNTAINS, LORAINE.

I hoped to find abundant material in the spruce forest near the source of the river Sar, in the central Vosges Mountains where I had learned that much timber had been broken down by heavy snows. We arrived at Aberschwiller that night, and the next morning called on Oberforester Piltz who kindly accompanied us by carriage, narrow gauge railroad, and on foot, into the midst of the great forest of white spruce. Here was found a most remarkable and interesting feature of the forest destruction by storm and snow.

GREAT DESTRUCTION OF TIMBER BY SNOW AND WIND.

It appeared from information obtained from Oberforester Plitz that on the 30th of March, 1892, while a thick and heavy mantle of wet snow was on the foliage and branches of the trees a severe wind storm coming from the east swept a path through the forest from near Shermec, in Elsass over the Donan mountains and across Loraine to Cornnauexan in France, cutting a path from four to five miles wide, and over twelve miles long, in which almost every tree was prostrated. Over a greater portion of the area the tall, straight and matured spruce trees had stood so thick that their prostration was made the more complete by the great weight of snow. In fact, when the trees commenced to fall on the border of the forest, the others against which they fell were pushed down in the same manner 
as is a row of dominoes when set on end and the first one is made to fall against the seconci.

Thus, all of the trees were prostrated in one direction, not crossed and tangled as is the case when timber is blown down by the wind alone.

At the time of our visit all of the half million of prostrated trees had been counted, the quantity of timber estimated, and what was more surprising and interesting, every tree had been stripped of its bark from root to top to prevent the attack of a bark beetle, (Pityogenes curvidens), and after a timber beetle Xyloterus lineatus, the larter is believed to be identical with our spruce bark beetle, Xyloterus bivittatus. 'The bark, large branches and even the small twigs had been cut into short lengths and neatly pilled or tied in bundles to be sold for fuel. The bark was removed by contract as soon as possible after the timber fell, and the price paid being 30 phenigs ( 15 cents) per cubic meter. One cubic meter equals about $1-4$ of a cord. One man could peel an average of about nine trees a day.

While I felt very well repaid for visiting this region, in what was learned by the action of snow and storms, and of systems of forestry management under government control, I was disappointed in not finding the conditions favorable for the Clerids. In fact over this vast area of felled timber, there was no place for bark beetles to breed, and consequently, nothing to attract the Clerids. An earnest search was made among the standing timber for trees that were dying from the attack of the little spruce bark beetle, Pityogenes curvilens, which at tacks the bark on the upper portion of the tree in the same manner as does our destructive pine bark beetle.

\section{A SPECIAl, FAVOR.}

The Oberforester ordered a large tree that showed some indications of attack, to be felled especially for my inspection. In consideration of the value of the trees and the fact that so many trees were already down was an unexpected favor, and one which was greatly appreciated. 
Just as we were leaving the forest, and too late to look for Ulerids, a small spruce tree was observed that was evidently dying from the attack of the bark beetle, Pityogenes curvidens. A hurried examination revealed a number of examples of this species.

We returned to Aberschwiller at 5 p. m., wet and tired from our day's tramping through the forest in the rain. It had not only rained hard all day, but had turned quite cold which contributed all the more to our discomfort.

\section{RETURN TO HAGENAU.}

The next morning we returned to Hagenau where we arrived at 9 a. m., and after Iuncheon we proceeded to the forest where in four hour's $I$ collected $225^{\circ}$ examples of the Clerid. Mr. Baldouf, (the Landforestmister), my guide, and the driver together secured 175, making 400 living specimens collected in that short time, which is sufficient evidence of the abundance of this insect where the conditions are favorable for it. A large number, possibly 250 or more, were either killed or injured in cutting them out of the bark. Since these were of no value to us, they were not taken or even counted. The Clerid was exceedingly common in the bark of some of the injured trees, and was frequent in all that were infested by the bark beetles.

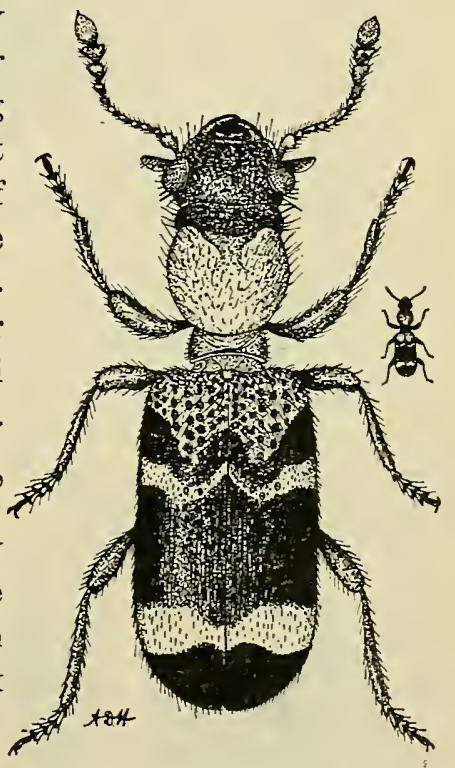

OBSERVATIONS ON THE HABITS OF Fig. XXXIX.-Adult of European CLERUS FORMICARIUS. bark beetle destrover, dorsal view. Small figure on the right natural size.

From what I observed of the relation of the Clerid to the pine bark beetles, $M$. piniped $a$ and $M$. minor, which are among the principal enemies of the European pine forests, it was evident 


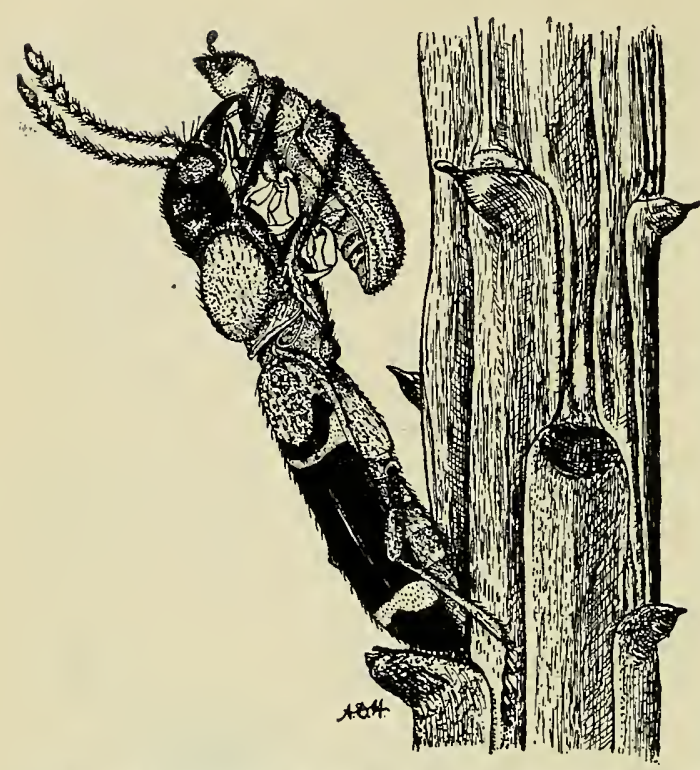

Fig. LX.-Adult of European bark beetle destroyer feeding on bark beetle. to me that they were alone capable of preventing an excessive increase of the bark beetles, (see Fig. LX,) and thus prevent an extension of their ravages beyond the injured and felled trees. In many instances noted, the Clerid has so completely destroyed the young or larvae of the bark beetles that but very few matured examples could be found in

the bark of the trees which otherwise would have contained many thousands.

It was also evident that had it not been for the beneficial in. fluences of the Clerid in this forest where so much broken timber occurred, that the numbers of bark beetles would have been sufficient to attack and kill the uninjured trees, as our Dendroctonus was doing in West Virginia.
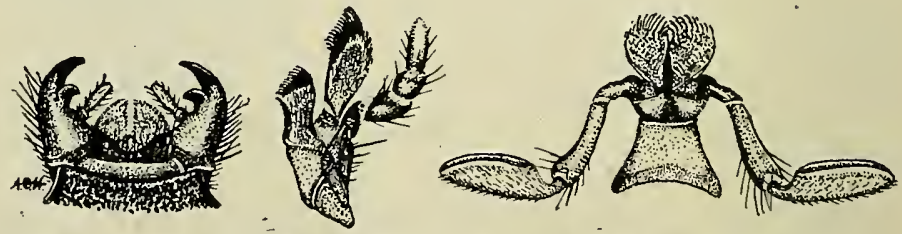

Fig. XLI.-Mouth parts of adult of European bark beetle destroyer.

The injured trees were being rapidly worked up into lumber and fuel, in order to destroy the bark beetles and thus avoid a possible invasion by them the following spring, but I was convinced from what $I$ had seen that while this was apparently an 
important precaution, it did not seem necessary; since the Clerid had demonstrated its ability, under ordinary conditions, to keep the bark beetles under complete control. With this knowledge of the capacity of the Clerid in destroying bark

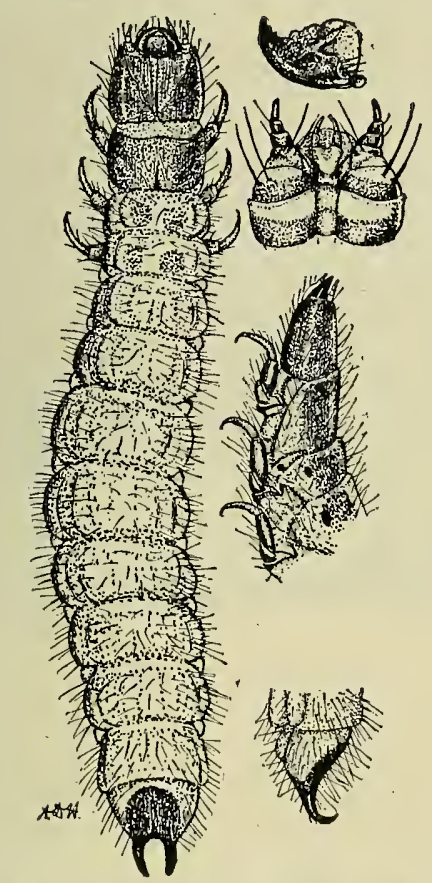

Fig. XLII.-Larva of European bark beetle destroyer greatly enlarged.

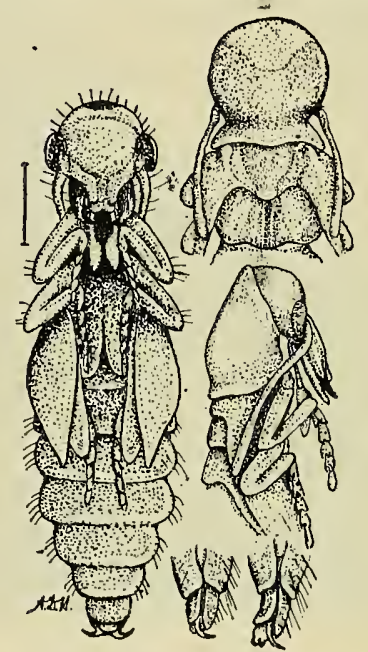

Fig. XLIII.-Pupa of European barlk beetle destroyer greatly enlarged.

beetles, I felt very well satisfied that if it could be successfully introduced into America, and would become established in our coniferous forests, that it would, under favorable conditions, accomplish the desired end. We returned to the hotel at $5 \mathbf{p}$. m., and after making further arrangements with Mr. H. Strahmeyer to engage a sufficient force of help to collect the Clerids in the greatest possible numbers during my stay in Germany, and to collect and forward material to me after my return to America, I returned to Strassburg, where I arrived that night.

FURTHER WORK PREVENTED BY A CHOLERA EPIDEMIC.

Upon going to my hotel, I found a letter which, as the follow. ing extracts will show, presented some discouraging features to my proposed prosecution of the work, and when I had procured 


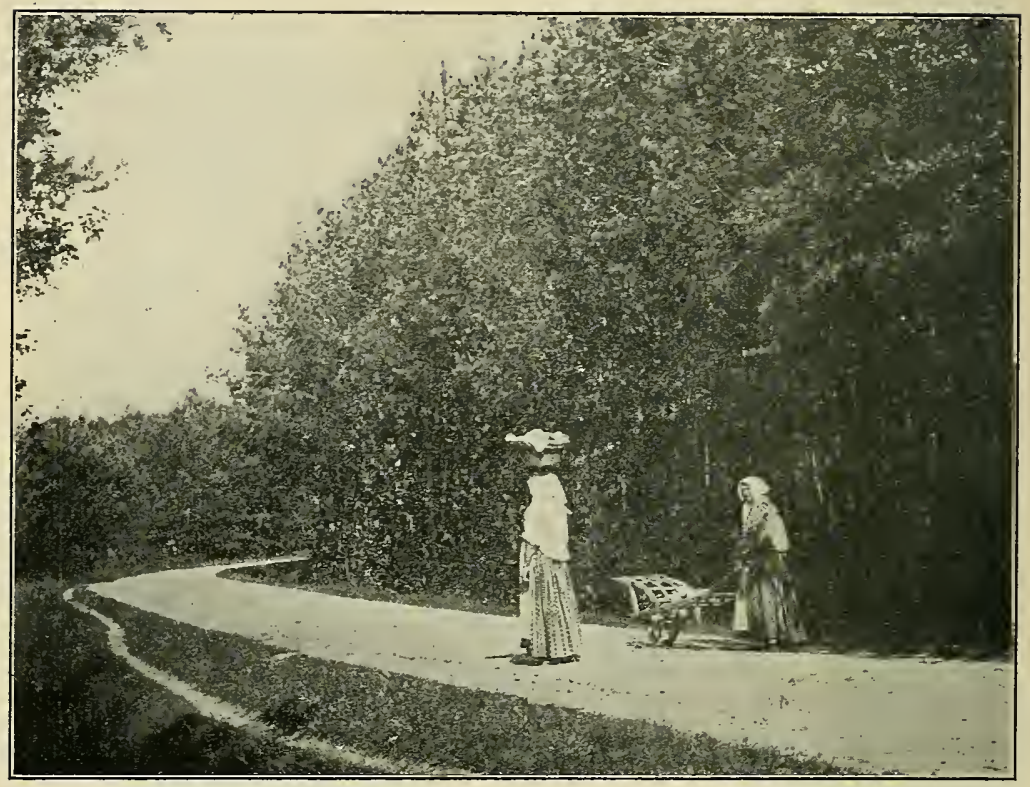

Fig. XLIV.-Young pine forests, road, path and peasants, near Hagenau, Germany.

some newspapers and read the alarming accounts of the conditions at Fire Island, N. Y., and on some of the steamers that had recently arrived in the New York harbor; also of the measures taken to prevent the spread of cholera in Europe, I realized the necessity of discontinuing active operations, and that if I was to get away from Germany before winter, I must proceed without delay into a country which was free from the disease.

\section{LETTER FROM DIRECTOR MYERS.}

Morgantown, Tr. VA.

DEAR Sir: August 2\%th, 1892.

"Since you left here, it is evident that you have run into a country at least more or less surrounded by cholera, and at present writing, cholera is announced at most of che German seaport towns from which the prominent steamship lines sail for this country. The same is true of France, and will doubtless be true in a few days of England. The effect of this will be that everything and everybody coming into New York will be thoroughly funigated and snbjected to very rigid inspection until after the 
cold weather shall have allayed the ravages of the disease. Such being the case, it will be useless for you to attempt to bring any insects alive through the treatment to which everything and everybody will be subjected upon entering this country, so that it will be necessary for you to arrange to have these insects sent here after the quarantine regulations are changed. In fact, it may be difficult and dangerous for you to sail until cold weather shall have allayed the virulence of the attack in the European cities. My advice to you would be to keep out of the large cities, and if the cholera should spread rapidly in Germany, which it may do for a few weeks, it would be best for you to go to some village out in the mountains where you can live cheaply and at the same time be free from danger of infection.

I am not particularly uneasy about you, as I feel that you will take pains to avoid the disease, but I am convinced that so far as your being able to import any insects at present is concerned, your trip will be a failure, and that all you can do will be to arrange to have the insects sent to you later. * * * Trusting that you may be successful, and that you may avoid all dangers, I remain,

(Signed) JoHN A. Mrers, Director.

After due consideration of the matter I decided to go into Switzerland and remain for a time in the Alps, where I fell safe from the disease and at the same time, obtain much needed rest and recreation. I spent the greater part of the day, which was Sunday, with Oberforester Eichhoff, and upon returning to my hotel, found a package from Director Schaufuss, containing 185 examples of the Clerid. This accession to the collection made a total of something over 1058 examples of the Clerid collected to date (Sept. 11.) Some 50 examples had died from injuries, leaving a little over 1,000 living examples which were in first class condition.

TEN DAYS IN SWITZERLAND.

After writing to Director Schaufuss and Mr. Strahmeyer informing them of the change in my plans, and notifying them to cease collecting Clerids until further notice, I proceeded by rail up the valley of the Rhine to Luzerne, in Switzerland, where $I$ arrived in the evening of Sept. the 12th.

I remained in Switzerland until September the 24th, visiting the various points of interest between Luzerne and Berne, but: spending the greater part of the time in the Lauterbrunnen Valley in company with Dr. Hillgard, the Director of the California Experiment Station and party, including his family, which I had the pleasure of meeting at Grindlewald.

Among the many interesting features of my stay in Switzer. 
land, but few are worthy of mention in this connection. I made collections of such insects and interesting plants of the Alps as I could find ${ }^{1}$ and some interesting observations were make on features of Alpine forest management and insect enemies of trees. While on the Rigi I collected a number of varions species of bark beetles on the snow, to which they had been attracted in their flight from the warmer valleys. Along the path that leads up the Great Scheideck through Schwarzwald, I found a number of spruce trees at an altitude of possibly 5,000 feet that had been recently felled, in the bark of which the spruce bark beetle Tomicus cembrae occurred in enormous numbers. In the bark of these trees, I also had the good fortune to find a few Clerid larvae, evently of the same species as the ones collected in Germany. Subsequently I found in the bark of recently felled spruce trees, in the Lauterbrunnen Valley, both adults and larvae of Clerus formicarius, in company with Tomicus cembrae and Dryocoetes autographus. Thus proving that the Clerid would attack bark beetles of different species, and that it would live in the spruce as well as the pine. Also evidence was found that it could survive at as high or higher altitudes than any in West Virginia. This discovery was of special interest, indicating as it did that the Clerid would adapt itself to all of the varied conditions and requirement of the West Virginia forests, if it could be successfully introduced and established there.

RETURN TO AMIERICA.

Finding by the 24 th of September that I could get through France to England without much trouble or delay from quarantine regulations, 1 left Switzerland via Berne, Delle and Collas and arrived in London on the 25th, and from London proceeded via Nottingham to Liverpool, from which point I sailed on the night of the 2Sth in the same steamer (City of New York) that brought me over.

After a stormy but safe and pleasant voyage, I arrived in New York on the 5th of October. A brief examination of the 
passengers was made at quarantine, but our baggage was not fumigated.

A portion of the collection of Clerids was kept in cold storage during the voyage and came through in first class condition, as did these kept in my stateroom. As soon as possible after landing I proceed to the B. \& O. depot in Jersey City, and in a few minutes was on my way home.

STOP AT WASHINGTON AND ATTEND A MEETING OF THE ENTOMOLOGI-

CAL SOCIETY.

Arriving in Washington, D. O. on the morniug of the 6 th and having a few hours to spare, I called on the Government Entomologist, Dr. C. V. Riley, at his office in the Agricuitural Department, for the purpose of consulting him with reference to the possibility of any harm coming from the introduction of the Clerid into America. He manifested a deep interest in the undertaking and insisted that I should remain in the city that day and attend a meeting of the Entomological Society of Washington to be held that evening. Realizing that this would be a good opportunity to get an expression from some of the leading Entomologists of the country with reference to the good or harm that might result from the importation, before any were liberated, I decided to accept Dr. Riley's kind invitation to dinner and to accompany him to the meeting.

During the day I found a number of species of bark beetles in a dying spruce tree standing in front of the Smithsonian Institution, the destructive pine bark beetle occurring in the bark of this tree in great numbers, In fact, the tree was evidently dying from the attack of this insect. Securing a number of living examples of the different species of bark beetles, I placed them in bottles with living adults of the imported Clerid, and was pleased to find that the Clerid attacked them with evident relish. This was shown at the meeting during the evening, and the ravenous appelite of the Clerid and its systematic method of attacking its victims was very interesting and was evidently appreciated by the members who saw it.

The following extracts from the proceedings of the Society, Vol. 11, No. 3, p. 353, and the substance of my remarks, and as 
published in Insect Life, Vol. V. No. 3, p. 187-9, is here presented as an important feature in the history of the work. Extract from proceedings of the Entomological Society of Washington, Oct. 6th, 1892 :

\section{REMARKS AT MEETING OF ENTOMOLOGICAL SOCIETY OF WASHINGTON. ${ }^{1}$}

"It appears that an unhealthy condition of the pine forests in West Virginia and Virginia has existed in certain points in the Allegheny Mountain range and adjacent foot hills since about the year 1888, but had only attracted local attention until within the last two years, when its rapid spread and increasing devastation brought the matter to public notice, and it was referred to this Station, and to me, for investigation. I have, therefore, made two extended journeys through the eastern portion of our State, one in May and the other in July of this year, for the purpose of ascertaining the character and cause of the trouble and the extent of the damage, and also to discover, if possible, a remedy.

It was found that when this trouble commences in a healthy forest, groups of trees numbering from two to a dozen or more are noticed dying the first year. The foliage of such trees first turns yellow and then red, as if killed by fire. The second year this pecular condition will have spread until the groups of dying trees extend over one to ten or more acres, and by the third year the entire forest of pine trees of all kinds, on hundreds of acres is often found dead and dying.

After studying all the conditions found, and a due consideration of all the visible and probable elements which might produce them, I was convinced that a single species of Coleopterous insect, Dendroctonus frontalis was to blame for the primary attack and resulting death of the trees.

From personal observation it was found that the dead and dying condition of the pine extends from near the Pennsylvania line in Maryland on the north, through Hampshire, Hardy, Grant, Pendleton, Randolph, Pocahontas and Greenbrier, to Summers and Raleigh counties in West Virginia on the south, and from inquiry and correspondence I learned that the same condition extends through about an equal area in Virginia. Therefore, it would seem that the ravages of this beetle extends over an area of at least 10,000 square miles, including portions of West Virginia, Virginia and Maryland, on which five species of pine and the spruce are being damaged and killed to a greater or less extent by them. In certain sections entire forests of pine, including all species on several square miles, are dead and have been a total loss. The greatest destruction has been in the forests of the common pitch pine (Pinus rigida, Miller) and the scrub pine (Pinus Virginiana, Mill., or inops, Ait), and in the less common but less valuable yellow pine (Pinus echinata, Mill.)

The extensive and valuable forests of black spruce (Picea mariana), and white pine (Pinus strobus $L$.) in West Virginia are being invaded by insects; therefore, owners who have large intérests in such timber are becoming alarmed. The ravages of the insects in the other pines have been of such a serious character, the spread so rapid; and the destruction so complete, that there is really good cause for alarm, and should this destructive work continue in the spruce and white pine of our State, and the invasions of this insect extend into the great pine forests of the southern States, many millions of dollars will be added to the great loss already sustained.

1 Published in "Insect Life," Vol. V, page 187. January, 1893. 


\section{REMEDIES CONSIDERED.}

At first, a remedy against the rapidly spreading ravages of the beetle, seemed out of the question, but when it was found that they had just commenced their attack upon the forests of black spruce and white pine it indicated that possibly some method could be found by which the healthy and more valuable portions of these forests could be protected.

The method of cutting and burning the first infested trees to destroy the insects was considered, but it was found that it could not be generally practiced in our West Virginia forests, owing to many difficulties and conditions rendering this as well as other like methods impracticable.

The occurrence of a similar trouble in our spruce forests between 1882 and 1889 caused evidently, by the spruce bark beetle (Polygraphus rufipenmis), was, I have every reason to believe, brought to an end principally by the appearance of some six species of parasites and predaceous insects, which were found preying upon it. This, together with the well known success of the introduction of Vedalia cardinalis from Australia into California, resulting in the destruction of the Icerya, led me to consider methods of combating the destructive pine bark beetle, and to carry into effect a previously contemplated experiment of introoucing certain insects from Europe to feed upon some of our injurious bark beetles.

By correspondence with Oberforester Eichhoff of Strassburg, Germany. I learned that a certain beetle, Clerus formicarius L., was a "great destroyer of Scolytids" in the forests there. and from my knowledge of the habits of the nearly-related species, Thanasimus dubius, Fab., I felt that it would be a most desirable species to introduce into our forests to feed upon the destructive pine bark beetle, and possibly check it ravages. Therefore, the experiment of introducing this beneficial European species into our State for this purpose was recommended to our Station officials and to owners of the threatened spruce and white pine forests. This proposed experiment was at once approved and the Station, aided by liberal contributions from four of the principal lumber companies, sent me to Europe in quest of such insects as, in my judgment, would when introduced into our forests, accomplisl the desired end. I, therefore, proceeded at once to Germany, sailing from New York on August 17, and arriving at Strassburg on August 27, and after visiting some of the principle pine and spruce forests of Aslace, Lorraine and Saxony, in Germany, Schwyz, Lucerne, and the Oberland Bernese Alps in Switzerland, I started back to America on September 25, with over one thousand live specimens of Clevus formicarius, which was found to be especially destructive to various bark beetles in all of the forests visited. ***

The following extracts, translated from an article in German published in "Science"1 in November, 1892, by Director Camillo F. Schaufuss of Meissen, Saxony, will give some additional information:

\section{"ON THE INTRODUC'TION OF THE EUROPEAN BARK BEETLE DESTROYER (CLERUS FORMICARIUS), TO AMIERICA."}

* * * "It has certainly been very plainly seen in Nature that in her domain equilibrium should be retained. She has therefore placed a limit to the excess of individual animals, in which she causes their enemies to associate. Besides birds, insects have very many other destroyers, especially 
among themselves. There is a large number of predaceous insects in all the orders, which like highway robbers, attack other individuals. On account of the particular taste of the enemy they seize only certain kinds of food. Therefore, wherever nourishment occurs for insects their enemies are also associated with them, and finally malicious sneakers, the internal parasites, which are found in great abundance in the Hymenoptera and Diptera, prey upon their hosts. * * * *

* * * In July of this year Mr. Andrew D. Hopkins, of the W. Va. Agr. Exp't Station at Morgantown, communicated to the readers of Science, Vol. XX,1 how in late years the bark beetle, Dendroctonus frontalis, Zimm, has appeared in such vast numbers in West Virginia that upon a territory of $10,000 \mathrm{sq}$. miles $75 \%$ of all pine trees have been either injured or killed outright. * * * Therefore. Mr Hopkins has conceived the idea, that after he had observed how Clerus dubius, $\mathrm{F}$. gave troubie to the Scolytids by thinning their ranks, to place with it Clerus formicarius, L. to help in its good work in order, at least, to do what is possible to overcome the enemy of the forest.

Europe and North America have had foi a long time an active commerce between both sections of country and through the similarity of climate there has been a reciprocal exchange of injurious insects. I am reminded of the introduction of the potato beetle (Leptinotarsa decimlineata, Say) into Germany, and the cabbage butterfly (Pieris brassicae [rapae.] L.) into the United States. Why not also introduce beneficial insects?

Mr. A. D. Hopkins did very well indeed to direct his attention to Furope. And as a fact we have in Clerus formicarius a beetle that not only closely resembles in its appearance, size and color its American brother, Clerus dubins, F., but also similar to the latter in its mode of living. It is, as a larva, as well as adult, a keen enemy of the coniferous bark beetles. No matter whether the bark beetles live upon the pine or fir, the Clerid occurs in considerable numbers. For this reason Mr. Hopkins chose it [C. formicarius] for importation to America.

In order tó carry out his plan he pleased himself in communication with the eminent Scolytid specialist, Eichhoft and myself, and in August came to Europe to study the life history of the insects and collect them.

Mr. Eichhoff wrote to me while Mr. Hopkins was collecting in Alsace that he [Hopkins] worked "with extraordinary skill and great suceess," and I can corroborate his particular view, as I was for many days in company with Mr. Hopkins in the Saxon forest searching for Clerids. We found the larvae, the pupae, even the emerging imagos in their artistic winter quarters within the bark.

Thus, Mr. Hopkins can look with satisfaction upon the result of his journey for he took a large number of Clerids in all the localities visited, and for safety in transportation one half was packed in one way and the other half in another. And at that time probably but a.few would succumb, since by far the greater number had arrived at their winter rest. If on account of the exaggerated cholera scare, the quarantine does not destroy Mr. Hopkins' treasures the experiment of acclimatization can be commenced in the spring. A sufficient additional batch will be provided by me to enable Mr. Hopkins' experiment to succeed."

FIRST IMPORTED CLERIDS LIBERATED IN AMERICA.

After my return to Morgantown on Oct. 7 th, the subject of the distribution and colonization of the examples I had brought over with me was duly considered, and it was decided that

1 Quoted on another page. 
probably the best results would be gained by keeping the insects until the following spring when the conditions would be more favorable for them to survive. A great many of the larvae had entered the cork stoppers of the bottles, and had made therein their cocoons in which to change to pupae. It was therefore thought that this was the most favorable conditions for them to pass the winter, and that they had best be not disturbed. It was feared, however, that the adults would not survive, but since there was not a sufficient number of these to justify a distribution to the timber companies, I decided to place them in pine woods near Morgantown where a number of trees were dying from the attack of the destructive bark beetle, and on Oct. 10th, 1892, 50 adults and 25 active larvae were placed on and in the bark of a group of dying scrub pines on Mayfield Hill, about seven miles from Morgantown, this colony being the first examples liberated in America. The liberated adults were olserved by myself and Prof. F. W. Rane, who accompanied me, to attack and devour the bark beetle, as well as other species of bark beetles which occurred on the bark of the trees.

\section{LETTER TO TIMBER COMPANIES.}

The parties who had contributed to the experiment were notified of my return, and the results of the expedition in a letter dated Oct. 13th, 1892, a copy of which is here given:

DEAR SIR:

October 13, 1892.

You will no doubt be interested to learn of my return from Europe, and my success in finding an inseet, which, I have every reason to believe will prove very beneficial as a destroyer of our destructive pine bark beetle. This beneficial insect, which has been named "The European Bark Beetle Destroyer", was found very common in certain forests in Germany, where it was feeding on a pine bark beetle similar in appearance and habits to our destructive species.

I had hoped to collect large numbers of the species to introduce into our forests this fall, but on account of the cholera epidemic and the strict quarantine and fumigating precautions, I felt it would be impossible for me to get live specimens to America in time for them to be of any service this year. I therefore, collected only a sufficient number with which to carry on experiments in the laboratory and green-house this winter, and after arranging with parties in different sections of Germany to collect and forward to us many thousands of the species next spring, I proceeded into Switzerland on September 12th. to await an opportunity to return to 
America. By September 24th I found that I could get through to New York by the way of Liverpool, and I arrived in Morgantown on the 8th of October with one thousand specimens of the bark beetle destroyer.

As soon as possible after returning; I visited a pine woods near Morgantown and secured some of the pine bark beetles, which I placed in a bottle with a live specimen of the introduced species. The European beetle at once attacked and devoured the American species with evident relish, thus proving that they are not fastiaious in their tastes and indicating that they will attack and destroy the American bark beetle as readily as they do the bark beetles in their native woods. Therefore, as we have arrangeed to procure these beetles in great numbers from Europe next spring, we anticipate some very beneficial results and a great saving of timber by their proper distribution in our infested and threatened pine and spruce forests.

There is yet remaining $\$ 190.00$ of the amount contributed to the expenses of the experiment. This amount will be expended, unless otherwise ordered, to the best advantage in paying for collecting and shipping the insects from Germany next spring. The collectors will be required to send them as early as possible, and upon their receipt here, they will be forwarded direct to those who have contributed to the expense.

We cannot hope to do much, if any, good where the timber is nearly all dead or dying, but must turn our attention to protecting that which is now healthy or just commencing to die.

I will visit your forest at as early a date as possible for the purpose of giving instruction regarding the distribution of the insects in your forest when they are received from us. Therefore it is important that you should inform us as to the present character of the trouble in your best tracts of timber, and be prepared to point out to me the portions which it is most desirable to protect.

At a meeting of the Washington Entomological Society to which I was invited on Oct. 6th, I placed the following question before the society"Is there a possibility of this introduced species ever becoming injurious?" The question was discussed by Dr. C. V. Riley, U. S. Entomologist, and other prominent Entomologists, and it was the unanimous opinion that, from what was known of its habits, it could not be in any way injurious, but would likely prove beneficial.

The forest officials and entomologists in Germany and Switzerland were very kind in giving me every assistance in their power towards carrying out the object of my visit, and in addition to my success in finding the desired insect, I gained much valuable information regarding the method of forest culture and protection practiced there.

A detailed report will be prepared at an early date in which an account will be given of my investigations and observations. In the meantime, any information or request regarding the experiment which you may desire to communicate to us, will be thankfully received.

Trusting that our success may continue and that the experiment, made possible by your liberal contributions, will bring rich returns to you and to the timber interests of our State, I am,

Respectfully,

A. D. Hopkins, Entomologist.

THE IMIPORTED SPECIMENS STORED FOR THE WINTER.

Upon the approach of winter the bottles containing the remaining examples of the Clerids were placed in tin boxes and 
stored in a cool, dry room in the basement of the Station building, where the conditions were thought to be most favorable for them to remain alive until spring.

AN EFFORT TO SECURE LEGISIATION WITH REFERENCE TO THE CON-

TROL OF FOREST INSECTS.

During the winter arrangements were made to import the Clerids from Germany in the greatest possible numbers, and to distribute them throughout the infested forests in the most thorough manner. Realizing the importance of additional funds to that available from the Experiment Station and voluntary contributions, for the successful prosecution of the work, it was thought the State Legislature should make some provisions for more thorough prosecution of the work than would otherwise be possible. Therefore, the following letter was prepared by the Director of the Station on Nor. 26th, 1893, and copies sent to the members of the State Legislature then in session:

MPORTATCE OF HAVING MORE ENTOMOLOGICAL WORK DONE IN THE STATE

AND THE DESIRABILITY OF THE LEGISLATURE MAKING

PROVISION FOR IT.

(Copy of letter to Legislators.)

Through extended and careful investigation by the Entomologist of the Experiment Station at Morgantown, it has been ascertained that the pine timber on large areas in different sections of the State is being killed by a certain insect, which burrows under the bark of the living trees. He has found that the white and yellow pine timber on many thousands of acres, and even square miles, in this State has died, and, in most cases become a total loss; that the insects are spreading to healthy forests of pine, and are invading the extensive spruce forests, threatening a universal destruction of the pine and spruce timber of the State.

Upon the recommendation of the Entomologist in his report on his investigation, it was deemed advisable by the Staton authorities to send him to Europe to collect and introduce into our forests live specimens of an insect which was known to feed on and destroy insects like the species found depredating on our timber.

The expenses of this trip were shared by private individuals, and timber companies, who are interested in checking the ravages of the insect.

The desired insects were found in Germany in abundance, but owing to the cholera epidemic, he could not get them here in time to successfully distribute them in the forests last fall. He has, however, determin. ed to his satisfaction that the European species will readily feed upon the destructive pine tree insects as well as upon many other species of injurous forest and fruit tree insects. He is confident that if this beneficial species can be introduced in sufficient numbers, and properly distributed where they will do the most effectual work. they will not only aid in checking 
the devastations now going on, but will prevent similar outbreaks in the future.

Heretofore, it has been deemed impossib]e to check widespread depredations of insects in the American forests by any practical methods; therefore, the result of the introduction of this beneficial European insect into the TTest Tirginia forests, as an enemy and natural destroyer of the injurious species, is being earnestly watched by scientists and practical men in this country and Europe.

The experiment has gained the confidence of some of the leading Entomologists in Germany, who gave eficicient advice and counsel to our Entomologist before he went to Europe and while he was there. Upon his return to this country, the practicability of the introduction of the species, for the purpose above mentioned, was placed before the members of the Entomological Society of Washington, for discussion, and it was there determined by the U.S. Fntomologist and other prominent members, that the species could not be injurious, and the belief was generally expressed that it would prove beneficial.

If this experiment can be properly carried out, and succeeds in checking the spread of the destructive species, it will not only prevent the loss of millions of dollars worth of timber, but will demonstrate the possibilities of this method of dealing with forest and other insect pests.

We are informed by our Entomologist that it will only be by the intro. duction of the German insect in the greatest possible numbers, and their prompt and proper distribution, that we can gain the best results. It is, therefore, apparent that the work should be thoroughly organized, and every facility offered necessary to carry out the plans of the campaign against these forest tree pests during the following spring and summer.

In order to carry this work on properly and effectually a larger sum of money will be necessary than can be drawn from the Station funds. As it is a matter in which all owners of timber are interested, and especially of general interest to the State, if it be possible to avoid it, we should not be forced to ask for or accept further private contributions; but the expenses, in our opinion. should be provided by State appropriation.

The yellow locust, the different oaks, chestnut, wild cherry, poplar, maple, and other valuable kinds of timber trees are being serionsly attacked by different destructive species of insects, which are annually causing immense loss and damage. Since 1580, the loss to the agricultural and timber interests of West Firginia, occasioned by insects, may be safely estimated at one million dollars a year. New and destructive species are making their appearance, and their depredations upon our orchard, garden and field crops and live stock, added to the ravages caused by old pests, is fully realized by farmers and others who are thus having their profits reduced to a minimum.

In consideration of the fact that hundreds of millions of dollars have been saved to the agricultural and other interests of the United States within the last ten years by the prompt application of remedies and measures discovered and recommended by Entomologists employed by the Government and the several States, it is evident that this branch of scientific work is of the greatest importance, and there is no doubt that a large per cent. of the loss occasioned by insects in West Tirginia can be prevented at a comparatively slight expense, through systemaric work carried on by a Department of Economic Entomology, supported by sufficient funds for accomplishing the work.

Morgantown, W. Va., Jan. 26th, 1893.

John A. Mrers, Dir ector. 


\section{NO ACTION-TAKEN BY THE LEGISLATURE.}

No action was taken by the Legislature in the matter referred to in this letter, and it was therefore determined to accomplish everything that could be done with such funds as were available, and on March 29th, 1893, the following letter was addressed to lumber companies:

\section{LETTER TO TIMBER COMPANIES.}

"No doubt you will be interested to know how the experiment regard. ing the introduction of the European beetles is progressing. I have to say that the specimens I brought over have survived the winter and are now alive and in good condition. Te have been corresponding with our German collectors and have arranged to have as many more of the insects collected and forwarded to us as the available funds will allow. I am also making arrangements to carry on the work of distributing them during the latter part of April and May.

In distributing these beneficial insects, it is my desire to use special care in placing them where they will most likely accomplish the greatest good in the shortest time; that is, in my opinion, where the destructive pine bark beetles are just commencing their attack on a body of valuable timber which has heretofore been healthy. Therefore, you will aid us very materially in maturing the plans for the campaign by informing us at your earliest convenience of the points on your company's property which in your opinion would be the most desirable for me to visit for the purpose stated.

Ill-health and accumulating duties in my department due to my absence in Europe prevented my visiting the properties of any of the contributors last fall. However, if my health permits, I am determined to spare no pains in carrying on the work this spring and to accomplish all that is possible for us to do towards making the experiment a success.

Owing to the widely separated forests to be visited in different sections of the State, much time must necessarily be occupied in travel, therefore, any arrangements you can make which would expedite my investigations in jour forests will contribute largely towards our carrying on the work to the best advantage.

It will probably not be advisable for us to attempt to do much before the middle of April, especially in the mountain districts, but it is my desire to have the plans sufficiently matured that work will progress rapidly after it is once commenced.

While the Legislature failed to aid in this move, sufficient contributions have been volunteered to enable us to accomplish considerable work, if all gocs well.

Irusting that we may hear from you at an early date, I am.,

Respectfully,

'Signed) A. D. Hopkrns.

Satisfactory and encouraging replies to this letter were received and in April, the companies were notified of the dates on which I would visit their forests for the purpose of placing the first colonies of the insests and giving instructions for the placing of subsequent sendings as received from Europe. 


\section{IMPORTED INSECTS DISTRIBUTED IN 1893.}

Leaving Morgantown on the 20th of April, I proceeded to the southern-most localities first, and commenced the distribution of the Clerids in the white pine forests of Raleigh county. 100 examples were placed here in two colonies of 50 each; one on property owned by J. R. Beaty \& Co., the other on property owned by E. A. Monaghan. From Raleigh county I proceeded to Ronceverte, from which place I was taken in a buggy by Col. Driscol, who represented the St. Lawrence Lumber Co., and Mr. Dixon, who represented the Cumberland Lumber Co., up the Greenbrier river, through the extensive white pine forests owned by these two companies in Greenbrier and Pocahontas counties. Two colonies, one numbering 30 examples and the other 70 were placed in the timber owned by the St. Lawrence Co., and one colony numbering 100 specimens was placed in timber owned by the Cumberland Co.

From the white pine forests on the Greenbrier river, I pro-. ceeded into the spruce forests owned by the West Virginia \& Pittsburg R. R. Co., near the head of Williams river, in Pocahontas and Webster counties, where a colony of 100 examples was placed. From this point, I returned on horse to Welch Glade, in Webster County, and thence by rail to Morgantown, where I arrived on May 12th, and on May 19th I went on to the spruce forests in Randolph county, where I placed three colonies in timber owned by the Condon-Lane, Boom \& Lumber Co. and returned to Morgantown on May 26th.

\section{METHODS OF LOCATING COLGNIES OF IMPORTED INSECTS.}

In locating the colonies of Olerids, careful search was first made for locaities in which the conditions were most favorable for the Clerids to obtain necessary food, and the adults to deposit their eggs without having to wander away from the colony. The fact that all stages of the destructive pine bark beetle were found to be dead in all of the dying trees examined, indicated that the Clerid would have to depend upon other species of bark beetles than the destructive species, upon which it was intended to feed, the failure to find trees infested by living examples 
of the destructive pine bark beetle (Dendroctonus frontalis), while encouraging in indicating the possibility of the trouble coming to an end, was at first discourging so far as the success of the experiment was concerned, since the habits of this bark beetle correspond more nearly to that of the bark beetles upon which the Clerids fed in Europe, and would thus have offered better conditions for its multiplication than any other of our native bark beetles. It was found, however, that both in the pine and the spruce, living examples of many other species of bark beetles occurred in enormous numbers in the bark of injured, dying and felled trees, and although none of these offered the best conditions for the attack of the Clerid, it was thought that with proper precautions, it would attack them and become es. tablished in the localities in which colonies were placed. Where trees were found that died last fall, as well as those which were then dying from previous injuries by the destructive species, fairly good conditions were found for the Clerid to survive, as also in the bark of recently felled trees. Therefore, where such conditions were found near or in the best tracts of living timber, a tree or log was selected which had coarse flaky bark in which the pupae and larvae could be secreted, and a colony of from 25 to 100 were placed on it. When the desirable conditions were not found, one or more trees were felled and others girdled so as to attract the bark beetles to them. The imported insects were then placed in the moss or loose bark at the base of the girdled trees, or on the trunks of the felled ones.

If colonies were placed some distance from where the timber was being felled for logs, instructions were given to girdle or fell some more trees in the same locality in August and the following spring, in order to provide a constant supply of bark beetles which would thus be attracted to them. Careful and detailed instructions were given to a responsible representative of each of the companies with reference to subsequent location of colonies from the specimens which would be forwarded to them from time to time, as received from Germany.

During the fall of 1893 , adults that came in the packages, and as many as could be brạd from pupa were placed together 
in large glass jars with pieces of bark, where they were left for a sufficient time for the females to become fertilized. They were then placed in vials and forwarded to the distributors with orders to place them on the infested trees with the least possible delay. This method of liberating fertilized females offered the most favorable opportunites for the species to establish itself in the localities into which they were introduced, and if all other methods failed this one certainly must have succeeded.

THE CARRYING OUT OF THE PRIMARY OBJECT OF THE IMPORTATION OF THE CLERID INTO AMERICA PREVENTED BY THE DISAPPEARANCE OF THE DESTRUCTIVE PINE BARK BEETLE.

The primary object of the importation of the beneficial Clerids was to experiment with it as an enemy of the destructive pine bark beetle, and to secure, if possible, its co-operation with other enemies, in reducing the numbers of the bark beetle so that it could no longer overcome the resistence to its attack exerted by living trees, and thus bring the trouble to an end. The sudden death or disappearance of all examples of the bark beetles throughout the infested area in 1893 , and the almost as sudden ending of the trouble which had been caused by this insect, rendered it impossible to continue the experiment as originally intended. The best opportunity of establishing the Clerid in our forests was thns lost, since the conditions found in the euormous amount of standing, dead and dying timber which was infested by countless millions of examples of the destructive species and many other species of bark beetles were as favorable for the breeding and multiplication of the Cierid as could possibly have been desired, With the sudden change in the conditions, however, it became necessary to avail ourselves of the next best opportunity for establishing the species in our forests, and attain, if possible the secondary object of the introduction-namely, to get it to feed upon the bark beetles common to the bark of injured, dead, or felled trees. By this means it was thought that it could multiply and be ready to meet any subsequent invasion of destructive bark beetles. 
There was suitable and abundant material of this kind in the felled trees in lumbering regions, and, during the first season, in the standing trees which succumbed from the effects of previous injuries by the destructive bark beetle, in both of which numerous other surviving species of bark beetles occurred in great numbers. The trees that died from injuries by the destructive species were not common in 1893 , and became rare in 1894 , and since my observations with reference to the habits of the insects clearly points to the fact that the Clerid prefers to breed in the bark of standing trees to that of $\log s$, or felled timber, I fear that the liberated examples have met with some difficulty in establishing themselves, and since no absolute evidence ${ }^{1}$ of the species having become established in any locality in which they were introduced is had, we caunot say positively that the secondary object has been attained, but I am quite confident that if the pine and spruce timber should commence to die from the attack of the bark beetles, that the Clerid will make itself known and become common.

The secret habit of the adult of this Clerid and the close resemblance of its larvae and pupae to that of our native species of Clerids, together with the wide expanse of the pine and spruce forests of the State, would render it necessary for the species to become quite common before any one would be liable to meet with and recognize a single example. Therefore, while we have no absolute evidence that it is established in this country, the fact that it has not been frequently met with, is but little evidence that it is not established or even quite common in favorable localities. Time and subsequent events alone will prove whether or not any good will come from the introduction.

At any rate, the investigations made possible through the liberal contributions by the owners of the threatened timber, towards the expenses of the trip to Europe, both in the study of natural enemies of European bark beetles and the forest con-

1 I have been informed by parties both in the pine and spruce forests, who assisted in placing the first and subsequent colonies and were familiar with the distinctive character of the insect, that they had observed adults of the species the next season after they were liberated. 
ditions in Europe, together with the impetus given to the study of forest tree insects in this country with a view of determining methods of preventing loss from their ravages, will not be devoid of results of some value to the forest and timber interests of this State in the future.

NUMBER OF EXAMPLES OF THE CLERID COLLECTED, IMPORTED AND DISTRIBUTED BETWEEN AUGUST 29TH, 1892,

AND MAY 30TH, 1894.

Collectors. Date. No. Col.
A. D. Hopkins.... 1892. 160
C. F. Schaufuss ... $1892 . \quad 210$
H. Strahmeyer and
others........ 1892. $388=1058$
1000
Schaufuss. ....... 1893.
1920
1257
Strahmeyer, ..... 1893.
Schaufuss. ....... 1894.
3023
970
62
No. living when received at Mor- gantown.
Total
6063 collected.
3260 living.

\section{DISTRIBUTIONS.}

Companies.

Separate consignment of Colonies.

Amt.

Sub.

W. Va. \& Ya. R. R....

$100,66,75,75,100-416$

$\$ 150$.

Con. L. B. \& L. Co.....

$100,66,73,75,100-414$

$\$ 150$.

St. L. B. \& L. Co...... 30, 70, 66, 75, 75, 50, 50-416

$\$ 150$.

C. L. Co..............

$100,66,75,50,50-416$

$\$ 150$.

J. R. Beaty ...........

$50,33,38,38,50-199$

$\$ 75$.

J. B. Power...........

$50,33,38,38,50-199$

$\$ 75$.

W. Va. Agr. Expt. Sta.

$-140 \$ \$ 157.96$

Total .2200

$\$ 907.96$

STATEMENT OF EXPENDITURES.

1892. Total expenses of expedition to Europe including amt. pd. collectors and neces. sary service. 
1893. Total amt. pd.H. Strahmeyer, of Hagenau, for 3,023 examples of insects collected ..................... $\$ 103.00$

1893-4. Total amt. pd.to C, Schaufuss, of Meissen, Saxony, for 1920 examples collected..........................

Transportation charges on importations ..... Amt. subscribed by timber companies....... \$750.00 Amt. pd. from Expt. Station funds ........ \$157.96

Total ... ........... \$907.96 \$907.96

The expenses of distributing the Clerids to the timber companies were not charged to this account. 
FURTHER OBSERVATIONS WITH REFERENCE TO DYING PINE AND THE DESTRUCTIVE BARK BEETLES DURING

THE SUMIER AND FALL OF 1892.

Directly after the circular letter or special report was sent to the owners of spruce and white pine, on July 12th, 1892, I made arrangements to continue the investigation with a view of obtaining further information relating to the habits and life history of the destructive bark beetle, as well as to study the natural enemies of this and other bark beetles. Learning by inquiry that there was considerable pine growing in the mountains about seven miles from Morgantown, I visited on July 17th, 1892, the section mentioned, and found the conditions most favorable for conducting the desired studies. A number of large trees of pitch and yellow pine were found that were dying in the same manner as were those observed in other sections of the State, the bark on the upper portion of the trunk being infested with enormous numbers of the destructive bark beetles, and in many cases the beetles were literally swimming in the turpentine that was flowing into their freshly excavated galleries in the living bark. This section which I will hereafter refer to as the Tibbs Run forest, was visited again on July 24 th, when a large grove of seedling scrub pines was found on Mayfield Hill.' Hero numerous trees had died and others were dying from the attack of the destructive bark beetle, while many others which appeared perfectly healthy were found to be infested with the same insect, the adults of which were excavating their winding galleries through the inner, living bark, the balls of turpentine pushed out.by the beetles from the entrance holes being the only external indication of their presence. On some living and

1 To be referred to hereafter as the Mayfield Hill Grove. 
apparently otherwise vigorous, healtly trees these balls of turpentine were so thick on the bark that one could not find a vacant space as much as four to six inches square. Unlike the large infested trees that had previously been studied which bore branches near the top only, these had numerous branches from near the ground to the top. The same characteristic mode of attack was found, however, namely, that the upper or central portion of the main stem or trunk was attacked first the part subsequently infested extending from near the top to within three or four feet of the gronnd. The bark on the trees recently attacked was full of sap, and would readily separate or peel from the wood. In fact, it would separate as readily and the portion between the galleries made by the insects appeared as healthy as that from the most vigorous uninfested trees that could be found. No indication of disease or weakened vitality of the trees and no other species of injurious insects occurred on the foliage or in the wood or bark upon which the destructive bark beetle was just commencing an attack. It was observed, however, in the numerous trees that showed various progressive stages of attack, that soon after the first successful attack was made, or as soon as the tree showed the least indications of weakened vitality, that other bark beetles as well as other bark and wood boring insects were attracted to it.

The second one to appear being the turpentine bark beetle, Dendroctonus terebrans. This species never encroaches upon the portion of the bark chosen by its smaller relative, but, as a rule, enters the bark near the ground and even mines beneath the bark on the roots. Thus it contributes to the death of that portion of the tree which would otherwise remain alive for some time. Numerous other bark beetles then follow, attacking all parts of the tree, some boring in the wood, others invading the uninfested bark on the trunk, branches and twigs. Remarkable as it may appear, other species of bark beetles appear to respect the rights of the destructive bark beetles, since they seldom infest the bark occupied by it until the latter insect has vacated. Not so, however, with some of the large bark boring larvae which conduct their broad zigzag and winding 
mines.directly through the bark occupied by the galleries of the destructive bark beetle. Hence, if the young of these beetle have not already developed into adults and vacated, they are in this manner destroyed in great numbers.

In looking for enemies of the bark beetles, I have found a number of larvae and adults of a Clerid (Thanasimus dubius) which previous to this time had been rarely met with, as I was then contemplating the introduction of a near relative of this species from Europe, I observed closely its habits, a knowledge of which I realized would be of value to me, both in giving instructions to collectors in Europe and in readily finding the species, if I should visit Europe for the purpose. I found the larvae under the bark where it played havoc with the eggs, larvae and pupae and even young adults of the bark beetle. $I$ also found larvae in their recently constructed pupae cases in the outer bark, and the adults on the outside running on the bark and snapping up the beetles, and also in its hiding places under the flaky bark near the ground, all of which information proved subsequently, to be of especial value to me. What I learned here, together with that from previous observations on the habits of this species, was in fact, the secret of my success in finding the European Clerid so soon after I arrived in Germany. I felt confident that the European species would be found in the same stages of development and under practically the same conditions as was the American one, since by comparing specimens of the adults with examples of the foreign species received from $\mathrm{Mr}$. Eichhoff, I fonnd that they were very nearly related. They are also of the same size and color except that the European species has a black head, while the American one has a red head. The fact that they were nearly related also led me to believe that the European species would readily adapt itslf to the change of country. The fact that European species of insects when introduced into this country breed more rapidly than native species, are more aggressive, and as in the case of the cabbage butterfly, crowd out and take the place of native species, led me to feel confident that the introduction of the European Clerid would result in much good. 
A trip was made into Wood county on July 28th, returning Aug. 1st. Dying white pine and other species of pine were observed along the railroad in Ritchie and Wood counties, and some dying trees examined in Wood county were lound to be infested with the same destructive bark beetle as had been found in other sections. Here were also found some pine trees broken by snow the previous winter, which were infested by bark beetlẹs and Clerids.

After I found that I would go to Europe to study the enemies of Scolytids, I visited the Mayfield Hill Grove on Aug. 10th to make further observations, both with reference to the condition of the dying timber and the habits of predaceous beetles in which I was specially interested.

I found to my surprise that trees discovered on July 24th, that were infested by the destructive bark beetles were still living. There were no indications in the leaves that the trees were effected, and the bark would even then readily separate. Numerous other trees adjoining the infested ones were being attacked, as was indicated by the balls of turpentine escaping from the wounds made by the beetles. The bark of some of the trees that were being attacked on the 24th of July centained half-grown larvae of the bark beetle, and eggs were being deposited in the bark of the recently attacked trees.

ALARMING CHARACTER OF THE TROUBLE-NO FURTHER DOUBT RE GARDING TIE CAUSE.

These observations made it plain to me that the trouble was assuming a most serious character which was even more alarming than it had appeared to me at any previous time. If any doubl had remained in my mind as to the possibility of any other cause or associated cause for the death of the trees other than exerterl by the destructive bark beetles, there could be none whatever atter my observations of the conditions among these young and thritty trees ot one of our hardiest species of pines. 
FURTHER OBSERVATIONS ON NATURAL ENEMIES.

Some more examples of the predaceous Clerid (Thanasimus dubius) were found, but not common enough to be rendering much apparent service in reducing the numbers of the bark beetle. The rapid increase of this beneficial insect was probably prevented by two parasites, one which ${ }^{1}$ was bred from an adult collected at the time and another2 subsequently bred from the larva. (ther enemies of the bark beetle were found at this time, and still others had been previously observed, but none of them alone, or all combined, appeared to accomplish much towards checking the trouble.

Two adults of the Clerid (Thanasimus dubius) taken at this time were placed together in a bottle where it was found that they would vigorously attack each other and had to be separated to prevent both from being killed. I subsequently found that if one succeeded in killing the other, it would, if not seriously hurt, deliberately proceed to devour its victim. The same was found to be true with the larvae. This fact suggested the necessity (if members of the family Cleridne were to be imported from Europe) of placing each individual in a separate receptacle, and I found that small, glass vials just large enough to accommodate a single specimen, suited the purpose admirably. I also discovered that one adult Clerid when confined in a bottle, would readily attack and devour any species of bark beetle placed with it. The knowledge of these facts with reference to the habits of this American Clerid, proved to be exceedingly valuable to me in my investigations in Europe.

DYING SPRUCE AND PINE IN MARYLAND AND DISTRICT Of COLUMbia.

On my way to New York on Aug. 16th, I observed from the car windows on the B. \& O. R. R., large areas of dead and dying pines on the mountains in Maryland and West Virginia, the trouble having spread at an enormous rate since the previous May, Upon my return from Europe I observed, as previously noted, that the trouble had extended as far east as

1. Tachina sp.

2. Ichneumonid (?) 
Washington, D. C., where I examined a Norway spruce that was infested in the usual way by the destructive bark beetles and a number of its allies, I had no opportunity to observe the conditions through Virginia and New Jersey, since I passed through those States at night, but it was evident that if trees in Washington city were affected that the trouble must extend over the entire State of Virginia, Maryland, Southern Pennsylvania and New Jersey, wherever the pine grew in any quantity.

\section{OBSERVATIONS AFTER RETURN FROM EUROPE.}

Upon my return to Morgantown, I visited the Mayfield Hill Grove on Oct. 10th, for the purpose of making further observations and to liberate some of the imported Clerids. Here I found that many more trees had been infested than when observed on Aug. 10th, and that some of the trees that were found to be attacked on July 24th were even yet alive, and some of the trees which were not dead as well as others that were commencing to die, contained all stages of the destructive bark beetle from eggs to adults, some of the recently matured adults having emerged. The American Clerid was found to be far more common, both in the larvae and adult stage than on Aug. 10th, as were the parasite insects that attack the larvae of the bark beetle. The dying trees here, while of a different species of pine from these in which che Clerids were found in Germany, and infested with different species of bark beetles, were otherwise in practically the same condition. Therefore, the opportunity for the imported Clerid to make itself at home and begin operations at once were most favorable, except, perhaps, that it was too late for them to accomplish much in the way of breeding before winter.

On the 14th of October I visited the Tibbs Run forest and found among the large pitch and yellow pines the same conditions as on Mayfield Hill-namely, that the destructive bark beetle occurred in all stages in enormous numbers, and that their natural enemies, both parasitic and predaceous, were quite common. I found here, also, that in some of the dying 
and dead trees, the destructive species in all stages were dying apparently from the attack of a disease which I was led to believe from subsequent events was the beginning of the great epidemic that caused the universal disappearance of the insect from the forests of three or four States, or apparently from all of the infested area north of the Carolinas. 1

The Mayfield Hill Grove and Tibbs Run forest were again visited on October 21st, when living, parent beetles, eggs and young larvae of the destructive bark beetle were found in enormous numbers in the bark of an unusually fine specimen of the yellow pine, ${ }^{2}$ the leaves of which had just begun to change color.

These localities were subsequently visited on the $2 \mathrm{~d}, 7 \mathrm{th}$ and 11th of November, and on each of those dates the destructive bark beetles and their enemies were found in practically the same conditions as mentioned above. Some interesting observations were made on the 11th with reference to the different stages of the insects occuring at that date. It was found in all stages trom eggs to adults. Trees were then being attacked, the beetles mining in the living bark and depositing eggs. It was also found that the enemies of the bark beetle, including the disease, appeared to be on the increase.

The adults of the imported Clerids which it was feared could not be kept over winter, were liberated on the infested pines during the different dates mentioned, with the hope that they would seek their own winter quarters and thus possibly remain alive until spring, as they would do under natural conditions.

No ABATEMENT OF THE TROUBLE AT THE CLOSE OF 1892.

I found from correspondents in different parts of the State that the trouble was on the increase, and that, apparently the same conditions existed in other sections as at Tibbs Run and Mayfield Hill. Thus it was evident that there was no abatement to the invasion. In fact the indications were that all of

1 See under Cause of the Trouble Coming to an End, on another page.

2 Since this was written I find that there is a variety of the pitch or yellow pine, common in this forest which has smooth bark, grows to a large tree and otherwise resembles the jellow pine so closely that it is only by an examination of the leaves that the difference can be detected. 
the timber that was then alive would be attacked and destroyed the following spring, summer and fall.

OBSERVATIONS DURING THE SPRING, SUMMER AND FALL OF 1893. CONDITIONS IN MONONGALIA COUNTY ; SCRUB, PITCH AND YELLOW PINE.

On March 27th and April 3d, 1893, I visited the Tibbs Run forest and Mayfield Hill Grove, where I found that the scrub, pitch and yellow pine that had died the previous summer and fall, had not shed their dead leaves, and the bark on the base of the trunks was yet liring. Other trees that had apparently been dead one year had shed their leaves, but the smaller twigs had not fallen, while some of the scrub pine trees in the Mayfield Hill Grove that were attacked in July and November, 1892, were still living. A portion of the bark was dead on others, but the leaves had not changed color.

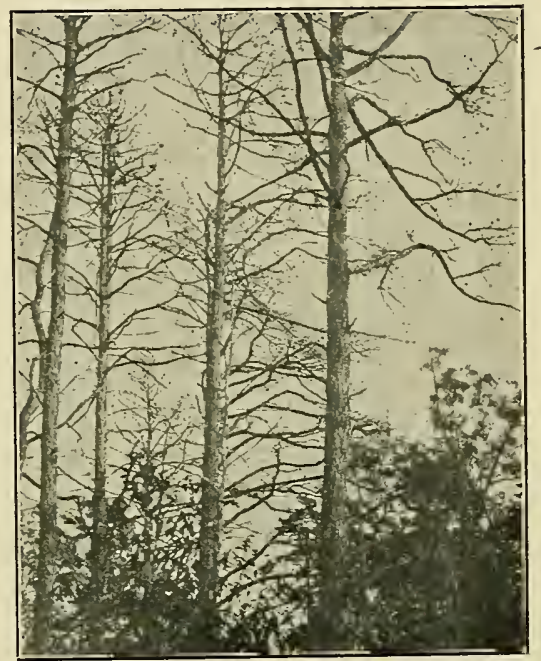

Fig. XLV.-Pitch pine killed by the destructive pine bark beetle, one year after attack.

The trees that had died the previous spring contained no bark beetles, but the bark, both outer and inner, was infested with large, bark boring grubs, and the wood with timber beetles and wood borers. In the trees that died during August and the fall months, bark and timber beetles and bark and wood boring insects occurred in great numbers in all parts from the roots to the terminal twigs, several species of bark beetles ${ }^{1}$ having passed tire winter in the bark and the outer wood of the small branches and twigs, 
while the adults of the larger species ${ }^{1}$ were common in the living bark at the base of the trees. Two species ${ }^{2}$ were also very common in the bark on the trunk of the trees. These were accompanied by several species of predaceous beetles, one of which $^{3}$ was very common in the galleries of Tomicus calligraphus and Dendroctonus terebrans. Clerid larvae were very common in the outer and inner bark at the base of the trees, probably the American species (Thanasimus dubius). The destructive bark beetle (Dendroctonus frontalis) both in the adult and larvae stage occurred in great numbers in the bark of the same trees, but all that I observed on both dates were dead. I thought at the time that they had been killed by the severe cold weather of the previous winter, but at the same time, it seemed remarkable that this species should be killed when all of the other species of bark beetles were living.

\section{CONDITIONS IN RALEIGH COUNTY.}

WHITE PINE.

While in Raleigh county distributing and colonizing the imported Clerids beiween April 25th and 27th; some interesting observations were made with reference to the condition of the trouble and the habits of the different bark beetles. Soon after entering the white pine forests of Beaver Creek on April 25th I examined a grove of white pine trees near Mr. J. R. Beaty's saw mill, which were supposed by Mr. Beaty to be perfectly healthy. I found that some of the finest trees, in fact nearly all of them, were being attacked by the large turpentine bark beetle (Dentroctonus terebrans) which indicated that the upper portion of the trunks had been attacked by $D$. frontalis. Therefore, upon my expressing a desire to examine the tops of some of the trees, Mr. Beaty had a number of them felled, and as expected, the most of them had been attacked by the destructive pine bark beetle during the previous fall. The bark on the upper portion of the trunk had been mined, as usual, in all directions by the beetle, eggs had been deposited, but none of them had hatched and all of the adults were dead. All of 
the trees so infested, as well as many of the trees that were not injured, were being attacked by the turpentine bark beetle, and some of them that had been seriously injured by the destructive species last fall, were being attacked by two species of bark beetles ${ }^{1}$ that were exceedingly common in the bark of saw logs and felled trees. Both of these hark beetles had been mentioned by Fitch, Packard and other writers, as among the worst enemies of the white pine in the north and the yellow pine in the south. It was therefore thought that those surviving species might attack and kill the trees that were then healthy. In fact, Tomicus pini was found mining in the green bark of living trees and depositing eggs. No trees in this grove or near it had diea, but the iudications. were that they would all die. Proceeding farther into the white pine forest, accompanied by Mr. Beaty and Mr. J. B. Power, we found numerous small groups of dead and dying trees, but no large areas upon which the timber had been killed. Upon felling and examining some of the trees that had died the previous fall and others that were then dying, I found upon removing the bark, that in every case all stages of the destructive bark beetle were dead, and where there were a great many larvae in the bark, the odor from their decaying bodies was very perceptible. It was also found that some of the large turpentine bark beetles, (both adults and larvae,) were dead, especially where they occurred in the bark some three or four feet above the base of the tree. The other two bark beetles, (Tomicus pini and Tomicus caelatus,) while occurring in great numbers in the dead and dying trees and in the logs ana tops of felled ones, none were dead, nor did they appear to have been affected in the least by the mysterious causes which had resulted in the death of so many of the other two species, especiaily of the destructive bark beetle which it seemed was completely exterminated.

ALL EXAMPLES OF THE DESTRUCTIVE BARK BEETLE DEAD.

Here was an exceedingly interesting condition, presenting at

1. Tomieus pini and T. caelutus. 
once new subjects for investigation and complications that had not been expected, which would possibly necessitate a change in the plans of conducting the experiments with the imported insects. The extent of the mortality of the destructive species was to be determined, and if possible, the causes of their death ascertained. I had found the destructive species dead in the trees in the norther part of the State, and here the same condition was found in the opposite or southern portion which indicated that possibly the species had been exterminated throughout the State, and that unless the timber continued to die from some other cause, the trouble must come to an end. But in the great number of other species of bark beetles, two or three of which it was thought were capable of attacking and killing the trees on their own account, there was a serious complication.

OTHER BARK BEETLES THREATENING THE TIMBER.

Indeed, it seemed as if the timber must continue to die with the enormous numbers of Dendroctonus terebrans and Hylurgops glabratus found attacking the base and roots of dying and living trees. With Tomicus calligraphus to attack as it was the lower portion of the trunk; with swarms of Tomicus pini and $T$. caelatus to invade the upper portion of the trunk and tops; with Pityogenes plagiatus to attack the small branches; and still other species of bark and twig beetles to attack the terminal twigs and other portions of the tree; with (wo or three species of timber beetles ${ }^{1}$ to perforate the sapwood; and the numerous species of flat headed (Buprestid) and round headed (Cerambycid) borers mining into the bark and wood of the injured and dying trees, it seemed that there was no chance for the remaining timber to escape. The only species, however, that was found attacking trees that were not injured in any way and not infested with any other insect, was the turpentine bark beetle Dendroctonus terebrans. In some sections scarcely a tree could be found that had not been attacked by this species always, however, in the bark at the base of the tree or the ex-

1 Xyloterus bivittatus $X$, retusus and Gnathotrichus materiarius. 
posed roots. So common were the adults at this point on some trees, mining into the living bark and pushing out masses of turpentine, that the tree was completely girdlded by their galleries. It was naturally concluded that such attacks as this would cause a diseased condition which would attract the other bark beetles and borers, and result in the final death of the tree. ${ }^{1}$

Numerous enemies of the bark beetle and of other wood and bark boring insects were found, but not in sufficient large numbers to indicate that they could cope with the excessively large number of injurious species.

Among the enemies of the bark beetle was a black, shining beetle, (Hister cylindricus,) which was common in the mines of Tomicus pini and Tomicus calligraphus, apparently feeding on the eggs and adults. A small rove beetle, (Staphylinid,) was also common in the galleries of all of the smaller bark beetles, including Tomicus pini, evidently feeding on the eggs, while Ips sanguinolentus and Ips vittatus was taken in the mines of Hylurgops glabratus. The American Clerid (Thanasimus dubius,) was frequently met with, but was not as common here as in other sections.

Among the round headed borers (Cerambycids) which were common in the dying trees, and appeared to be capable of mining in the living bark, was Arhopalus fulminans. This species was abundant in the larva and pupa stages, in the outer and inner bark and outer sapwood, its pupa cases occurring both in the outer bark and the wood. It had an enemy, however, in Thanasimus trifasciatus, the larva of which was common in its pupa cases. This Ulerid in turn, had an enemy in a parasite (Eupelmus cleri) which prevented its rapid increase. 25 to 30 larvae of the parasite were found in the body of a single Clerid larva.

CONDITIONS IN KANAWHA COUNTY.

SCRUB PINE.

Returning to Charleston, Kanawha county, I procured a horse and buggy, and drove about eight miles above the city,

1. It was subsequently found that many, in fact I believe all, of these same trees which were not otherwise injured, did not die and their health was not in the least in. jured, even when broods of the turpentine beetles had developed in the bark. 
where I had seen, from the car window, several patches of dying trees. The first one of these groups I examined consisted of only a few trees. The prime cause of their death was found to be due to injuries of stones rolling against them from a stone quarry. Another group was dying from injuries caused by the destructive bark beetle in 1892, and by the numerous species of bark beetles that had subsequently attacked them. The large group which had induced me to visit this section was found to be dying from injuries by fire.

The dying trees at the stone quary and those that had been injured by the destructive bark beetle were remarkably rich in specimens of bark beetles ${ }^{1}$ although no living specimens of the destructive species were found. The trees injured by fire contained very few examples of insect except the large bark and wood boring grubs.

\section{CONDITIONS IN GREENBRIER COUNTY.}

SCRUB PINE.

I went from Charleston tu Ronceverte, in Greenbrier county, where I arrived on April 30th. Having several hours at my disposal here, before I could go on to the white pine forests in Pocahontas county, I visited a grove of scrub pines nearby, where I had noticed several trees dying.

Upon examining the dead and dying trees, I found the same conditions as in other sections. The trees had been killed by Dendroctonus frontalis, but the insects were dead. Other species of bark beetle occurred here in great numbers, especially Dendroctonus terebrans, which was literally swarming around the base of the living trees and entering the bark. Adults of the Clerid (Thanasimus dubius) was also common, and were observed to attack and kill the large bark beetle ( $D$. terebrans), which, in consideration of the nearly equal size of the two insects and the strength of the bark beetle, was a remarkable

1 The following Scolytids and their enemies were collected principally in the injured trees at the stone quarry

Scolytids, Gnathotrichus materiarius, Fitch. Pityophthorus pullus, Zimm. Pityophthorus confinis, Lec. Pityophthorus lautus, Fitch, Tomicus cacographus, Lec. Tomicus avulsus, Eich. Tomicus plagiatus, Lec. Enemies, Aulonium tuberculatum, Lec. Hister cylindricus, Payk. Nemosoma cylindricum, Lec. Chalcophora virginiensis, Drury. 
feat for the Clerid. Two species of bark beetles were here added to my collection that I had not previously taken.1 They were in the bark of the roots of living trees.

The pine twig and bark curculio, Pissodes strobi, Peck, were also taken and a chalcid ${ }^{2}$ and a Bracon $^{3}$ parasite were subsequently bred from larve and cocoons taken in its larvae mines.

CONDITIONS IN GREENBRIER AND POCAHONTAS COUNTIES.

WHITE PINE.

Proceeding through Greenbrier into Pocahontas county on the 1st and 2d of May, with Col. Driscol, of the St. Lawrence Co., and Mr. Dixon, General Manager of the Cumberland Co., the same conditions were found as noted in Raleigh county, except that here more timber had died, having commenced in 1891. All the examples of the destructive bark beetles $(D$. frontalis) whether larvae, pupa or adults, that I observed here were dead, as they were in other locálities. Many trees were dying from previous injuries, but the trouble had not been very greatly extended since I was here in July, 1892, and the prospects were not nearly so gloomy as then. Enormous numbers of the turpentine beetle, Dendroctonus terebrans, were entering the bark at the base of the living trees in all parts of the forests which made it appear at the time as if one trouble had ended only for another to commence. The other common bark beetles found in Raleigh county were also abundant here.

The Cerambycid beetle (Asemum moestum), in the larvae and pupae stage, was common in the outer heartwood of trees killed by $D$. frontalis. A parasite (Pimplid) of this species was bred from cocoons taken in its pupa cases. Two Olerids (Trichodes simulator and Clerus quadriguttatus were taken flying around a tree infested with Tomicus pini and T. caelatus.

Upon an examination of the trees that had been dead one or more years, it was found that they were not, as a rule very seriously damaged by wood borers, with the exceptions of pin holes in the sapwood.

1 Hylastes tenuis, Zimm, and Hylastes cavernosu\&, Zimm.

2 Eurytoma cleri, Ashm.

3.Heydenia unica, C. \& D. 
CONDITIONS ON WILLIAMS RIVER.

IN THE SRRUCE. ${ }^{\text {I }}$

On May 6th I entered the black spruce forest on the head of Williams river, where I found the conditions about the same as in the spruce forests of Randolph county in June, 1892. The trouble had apparently not extended much beyond the first attack in the spring and summer of 1892 .

Numerous trees were here examined by the help of Andy Taylor, (of deer hunting and trout fishing fame, who was also an expert with the ax). While no trees were found in which the destructive bark beetle had bred, all the dead trees examined showed evidence of the attack of this species, and that it had been the prime cause of the death of the trees; but the spruce bark beetle (Polygraphus rufipennis) in all stages was exceedingly common in the bark, and it was very evident that while the trees might have recovered from the attack of Dendroctonus frontalis if they had not been attacked by Polygraphus rufipennis. None of the turpentine bark beetles, so common in the pine, were observed in the spruce, and the only indications of their presence here were a few wing covers under loose bark on a dead tree.

\section{SWARMS OF BARK BEETLES.}

Returning to Morgantown on May 12th, I learned from my assistant Mr. W. E. Rumsey and others, that a great swarm of bark beetles had passed through Morgantown on May 4th. They were especially abundant in and around furniture factories and new houses that were being painted, and wherever there was an odor of turpentine. In fact, they came as it was expressed, "like a hail storm," into open windows and doors, and was the cause of considerable alarm on the part of the inhabitants, who thought that a plague of bugs had visited the place. The new

1.Dryocoetes autographus was common in the bark at the base of the trees, Dryocoetes granicollis and Crypturgus pusillus were common in the bark associated with Polygrophus ruflpennis, Gnathotrichus materiarius and Xyloterus lineatus (bivittatus). were frequent in the sapwood. Two parasites of Polygrayhus were subsequently bred from coooons and larvae taken in its larvae galleries; namely a Braconid and Cecidostiba polygraphi, also a fly, the larva of which is an enemy of this species; larvae of the long horn beetle (Phymatodes dimidiatus) were common in the outer bark of dead trees and a Cryphalus species was cut from the bark of a small tree. 
greenhouses that were being constructed and painted at the Experiment Station was one of the central points of attraction. Here they occurred like swarms of bees.

While this remarkable swarm consisted mainly of the turpentine bark beetles, it would appear from the dead and living examples that I found in the green-houses and adhering to the paint, that it was accompanied by numerous species of bark and timber beetles, and also by some of their enemies. I was greatly disappointed that I did not see this swarm, or the many others like it which I subsequently learned occurred in different sections of the State about the same time, since it would have been very interesting and important to know the number of species that occurred in them and the approximate proportions of each. 1

On my way to the spruce forests on May 20th, I was informed at Bretz, Tucker county, that the swarm had occurred there on April 30th. They came from the southeast and "showered against the windows like hail," and entered through the open doors into the houses in such numbers that they had to be swept out. I found a few exaraples of the turpentine beetle in the office of Mr. Shaw, who informed me that it was the same insect that occurred in the swarm. At Mr. Frank Bennett's about fifteen miles further up the river (Dry Fork of Cheat) I learned that a similar swarm had visited that section about the same time as the one at Bretz. Here I found large numbers of the turpentine beetle in the webs of the apple tree tent caterpillar. The swarm that passed through Bretz and Morgantown doubtless originated in the dead pine timber of Hampshire, Hardy and Pendleton counties, and taking a north-westernly course passed over the Allegheny mountains and through the great spruce forests of Randolph and Tucker counties about

1. The species found in the greenhouses and on paint which evidently came in the swarm are as follows:

Species of Scolytids etc. in the swarm of May 4th, 1893.

1. Monarthrum mali, Fitch.

2. Gnathotrichus materiarius, Fitch.

3. Xyleborus xylographus, Say.

4, Tomicus cacographus, Lec.

5. Hylastes cavernosus, Zimm.

6. Hylastes gracilis. Lec.

7. Hylurgops glabratus, Zett.

8. Dendroctonus terebrans, Oliv.

9. Ips fasciatus, Oliv. 
April 30th, and reached Morgantown on May 4th. The swarm was also reported from different points along the W. Va. \& Pittsburg R. R. and from Pocahontas and Greenbrier counties, which would indicate that this remarkable occurrence was quite general throughout the spruce and pine areas. The fact that the turpentine beetle had been found so common attacking living trees and occurred in such enormous numbers in these swarms, together with the fact that numerous other species occurred in the swarms and in the bark of dying trees, led one very naturally to the conclusion that even if the destructive species had become extinct, the timber would continue to be killed by these surviving bark beetles.

CONDITIONS IN TUCKER COUNTY.

PITCH PINE.

On my way to the spruce forests owned by the Condon Lane Co., I found on May 20th, some pitch pines in Tucker county, along the Dry Fork of Cheat, that had' been defoliated by a sawfly larvae. Here as in the pines, in different sections of the State, I observed the turpentine bark beetle (Dendroctonus terebrans) in great numbers, attacking and mining beneath the bark at the base of the trees. No other bark beetles were attacking these defoliated pines.

\section{CONDITIONS IN TUCKER COUNTY.}

\section{WHITE PINE.}

In the section mentioned above there was found numerous white pine trees along the road and in every tree examined, the turpentine bark beetle was more or less common, mining in the bark of the living trees at the usual point of attack. A few of the trees had died from the attack of the destructive bark beetle, and others were dying from previous injuries, but no living examples of this insect were found. The living trees that were being attacked by the turpentine bark beetle showed no indications of injury from other insects or other causes.

CONDITIONS IN RANDOLPH COUNTY.

SPRUCE.

Entering the spruce forests on May 21st in Randolph county, 
I found that many trees were then dying, and that the trouble had spread some since I was there the previous June, but only as a slight extension around the borders of the groups of dead trees. Upon examining the dying trees and those that were only showing slight indications of weakened vitality, I found the living bark on the lower portion of the trunk infested with great numbers of the spruce bark beetle (Polygraphus rufipennis) which indicated that this species was the cause of the continued dying of the trees, but upon felling some of the trees thus affected, it was found that they had been previously attiacked (in 1892) by the destructive bark beetle, and that this species. and not the spruce bark beetle, was the prime cause, although the trees doubtless would have recovered, had it not been for the attack of $P$. rutipennis.

In distributing the beneficial Clerid in the timber on the summit of the mountain, practically the same conditions were found, as at other parts, i. e. the bark of all the trees that died the previous summer and fall, and of those that were then dying, was literally filled with the spruce bark beetle (Polygraphus rutipinnis) in all stages; while the destructive pine bark beetle, (Dendroctonus frontalis) in every case observed was dead.

Although examples of the turpentine beetles (Dendroctonus terebrans) were observed flying in the spruce forests and evidence was found in the stomach of trout ${ }^{1}$ that they had recently. occurred here in great numbers, only a single example was found mining in the green bark, and this had attacked a stump of a recently felled tree.2 None were found attacking living trees as in the pines.

\section{CONDITIONS IN GRANT COUNTY.}

SPRUCE.

Practically the same conditions were found on May 23d, near Baird, in Grant county, as in Randolph county, except that

1. The stomachs of trout caught at the time were found to be literally crammed with scolytids, consisting principally of Dendroctonus terebrans, Polygraphus rufipennis and Xyloterus bivittatus.

2. Further study of this species shows that it is closely allied if not 1dentical to Dendroctonus rufipennis, 
some of the species of bark beetles more commonly met with in the pine, were here found in considerable numbers miniug and depositing eggs in the?living bark of spruce logs cut the previous winter. ${ }^{1}$

There was one remarkable fact noted in all the dying and dead spruce trees that were examined, as well as in the numerous logs cut from trees, that had recently died namely, that while they had invariably been attacked by the destructive bark beetle, which had thoroughly mined the bark on the upper portion of the trunk, very few trees were found in which broods had developed; even where the bark.had died and offered the best conditions for their breeding, no indications in most cases were found of larvel mines. The greater number, in fact almost all of the trees examined had been killed, or their vitality impaired simply by the mining of the adults, the final death resulting from the secondary attack of other bark beetles, notably the spruce bark beetle, Polygraphus rufipennis. True some trees were found in which broods of Dendroctonus frontalis had developed, but such examples were quite rare, and in no case was a single living example of the species found in the bark of any of the spruces, or flying in the forests at this time.

\section{NORWAY SPRUCE IN MORGANTOWN.}

Upon my return to Morgantown on the 27th of May, I found that the turpentine bark beetles had attacked and were then mining in the bark of living, vigorous Norway spruces in town, and especially in some large trees in an old cemetery near the University, but nowe of them were dying.

CONCLUSIONS FROM OBSERVATIONS IN THE SPRING OF 1893.

In summing up the various features of the conditions as I had observed them in the different sections of the State.

I was led to form the following conclusions:

1st. That the destructive pine bark beetle Dendroctonus frontalis had been entirely exterminated, or its numbers so remon, while Gnathotrichus materiarius was frequent in the sapwood. 
duced that there was no longer any danger of its killing any more timber.

$2 \mathrm{~d}$. That the remaining healthy timber was threatened with an invasion of other bark beetles which had heretofore occupied the role of allies to the destructive species.

$3 d$. That the trouble would probably be continued in the pine primarily by the turpentine bark beetle, Dendroctonus tere. brans, with Tomicus pini, Iomicus caelatus, Tomicus calligraphus and Tomicus cacographus as its principal and most efficient allies in causing the death of the trees.

4 th. That the trouble would probably be continued in the spruce by the spruce bark beetle Polygraphus ruffpennis with Dryscoetes autographus and Dryocoetes granicollis as its principal allies, aided by Tomicus caelatus and the spruce timber beetle Xyloterus lineatus.

\section{CONDITIONS REPORTED TO THE OWNERS OF TIMBER,}

Upon my return to the Station from the investigations mentioned above, the following letter was addressed to the representatives of the several limber companies who had contributed to the expense of importing the beneficial insect:

(Copy of letter to timber companies owning white pine and spruce timber, dated May 27th, 1893.)

"I have just returned from the spruce forests in Randolph county, where I distributed the last of the first lot of the German insects. During my absence 330 more specimens came from Germany. Your share of these is 66 , which I mail to you to-day.

During $m y$ investigations in the white pine and spruce, I found that all of the trees that died last summer bore abundant evidence that their death had been caused by the destructive pine bark beetle. This species has, however, been greatly reduced in numbers, which would indicate that for a time, at least, no more timber will be killed by it. In fact, it is my belief that the German insects we are introducing may prevent them from ever increasing to sufficient numbers to cause further loss of timbor. The most we have to fear at present is the possibility and probability of other bark beetles (which have increased to such great numbers in the dying timber) attacking the healthy timber and contiuuing the trouble. One of the species, which has been able to multiply in this way, is especially threatening to the white pine. It is the large turpentine bark beetle, Dendroctonus terebrans) which I found attacking living trees. It has lately appeared in different sections of the State in immense swarms, and I found them attacking all of the species of pine. Therefore, with this new feature of the trouble appearing this spring for the first time, it is impossible for us to judge to what extent the timber will be killed before the German 
insect will have increased sufficiently to check them in their destructive work. It is hoped, however, that the worst of the trouble is over."

The same letter was addressed to owners of spruce timber, except that the following reference to the spruce bark beetle was added in the place of reference to the turpentine beetle:

"One of the species which has been able to multiply in this way, is especially threatening to the spruce. It is the spruce bark beetle (Polygraphus rufipennis) which I found attacking living trees."

\section{FURTHER NOTES IN 1893.}

WEBSTER, POCAHONTAS AND GREENBRIER COUNTIES.

Spruce. On June 33d-27th, accompanied by Professors Aldrich and Rane, of the University and Experiment Station, I visited and made an extended tour through the spruce forests at the sources of the Williams and Cranberry rivers, in the coun. ties mentioned above, where it was found that no timber had died recently, and the indications were that no further extension of the trouble would occur here, unless the spruce bark beetle should make an attack later in the season.

Monongalia County, Mayfield Hill Pine Grove. I visited this grove on July 15 th and found that the living trees that were attacked by the destructive bark beetle in July, 1892, as well as others attacked later in the same season, were yet living. The turpentine bark beetle had attacked these trees in the spring of 1893 , as previously mentioned, and a brood had almost aeveloped, yet the trees were living. In fact, none of the living trees that were attacked by the turpentine beetle had died, nor did they show any indications of doing so. Some of the trees that had been seriously injured by the destructive bark beetle during the fall of 1892 , were dying, and the bark was infested with all stages of Tomicus cacographus, of which two broods had apparently developed, the second bruod then emerging. In a small scrub pine tree that was felled the previous fall, was found a single adult of the spruce bark beetle (Polygraphus rufipennis), mining in the living bark but no eggs had been deposited. 'This was the first and only instance where I have observed this species in pine bark.

While numerous Clerid larvae were observed in the bark in- 
fested with the Scolytids and a few adults of Thanasimus dubius were observed, none were found that could be recognized as the imported insect.

In a paper read at a meeting of the Association of Economic Entomologists, I made the following reference to recent investigations with reference to the conditions previously referred to.

(Extract from paper entitled Destructive Scolytids and their Imported Enemies, published in the proceedings of the Association of Economic Entomologists and Insect Life, Vol. VI, pp. 123-130, 1893. Read at Madison, Wis. Aug. 20th, 1893.)

* * * There is one interesting fact, however, that I have observed this season regarding the destructive pine bark beetle Dendroctonus frontalis. and that is its numbers have been greatly reduced since last fall, consequently at this time very little if any timber is dying.

On the 24th of July, 1892, I found this species attacking and mining beneath the bark of living trees, 1 in which they occurred in immense numbers. By the latter part of September, a brood had emerged from the bark of the same tree while the leaves were yet green, and those that had emerged were entering the bark of other living trees. In Novamber the bark of the same trees was found to be infested by countless thousands of the insects in all stages from eggs to adults. T'rees so affected subsequently died, but through persistent search in the bark of such trees in different sections of the State I have failed, as yet this season to find a single living example of Dendroctonus frontalis. Hence the trouble, as caused by this species, is evidently at an end in West Virginia, for the present at least.

No other species of Scolytids infesting the same trees seem to have been affected by the cause which it would seem has rendered Dendroctonus frontalis almost extinct. In fact, the great number of trees that died last summer and fall were found last spring to be infested by immense numbers of bark and timber beetles of different species. These have since emerged, and it would seem that the only danger to be apprehended of a continuation of a trouble like that we have mentioned would be from the attack of some of the species which have thus emerged from the dead trees, for it is evident that unless they find favorable conditions in the felled trees, tops, stumps, etc., in lumbering regions they must either attack and kill living trees or perish,

One species, the turpentine bark beetle, Dendroctonus terebrans has already made a desperate effort in this direction. Early in May the adults emerged from the trees in which they had bred, but failed to find dying trees, the bark of which they preferred to infest for the purpose of depositing their eggs. Then followed a remarkable and interesting occurrence.

* * * They, with numerous other members of the Scolytid family, including both bark and timber beetles must have started, with one accord, in search of more favorable conditions for their propagation, for they occurred in different sections of the State, at about the same time, in great swarms like migrating locusts. Specimens were sent to us accompanied by startling accounts of plagues of bugs that visited mill yards, furniture 
shops, newly painted houses, etc. They were reported as coming like a hail storm against the windows and into houses through the open doors like swarms of bees, and that the air on all sides was full of them. During my absence from Morgantown (where our Station is located) one of these migrating swarms of Scolytids invaded the town and occurred at certain houses and at furniture factories in such immense numbers that some of the people became alarmed. The report was started that Hopkins's German bugs had devoured all of the pine bugs and were going to prove a universal pest like the English Sparrow. It was probably well for me that I was absent at the time.

The men were painting a new green house at the time, and the number of the beetles attracted to the building evidently by the odor of turpentine, were so great that the men were exceedingly annoyed in their work. When I returned to the Station several days after, I found evidence of their numbers in the handsful of dead beetles that failed to escape from the greenhouse.

Dendroctonus terebrans occurred in by far the greatest numbers in these migrating swarms, and when they failed to find dring or injured trees they attacked living pine of all kinds. black spruce and Norway spruce, entering the bark at the base of the trees. Some of the trees thus attacked in May were examined July 15, and the bark near the base was found to contain parent adults, eggs, and grown larvae, the larvae occurring in great numbers surrounded by the flowing turpentine. Trees thus infested were still living but the injury will probably cause a diseased condition of the trees, which will attract other species and result in their finaI death, thus we may be on the eve of a new destructive invasion like that which has just passed. Other species, like Polygraphus rufipennis in the spruce, Tomicus calliqraphus and Tomicuss cacographus, in pine, which are capable of existing in greeu, sappy bark, occurred in such abundance in the dying trees last spring that it is evident they must exist in the forests in great numbers, and are ready to attack trees showing the slightest indication of disease or weakened vitality, if they do not make a primary attack.

Therefore, the imported enemy will find abundant food and favorable conditions for its rapid increase in the infested bark of felled trees, tops, and stumps in lumbering regions in or near which the colonies have been placed.

The imported Clerid does not confine itself to one or two species of bark beetles in one kind of trees but the adults, it would seem, will attack and devour the adults of any species of bark and timber beetles found in the United States, and their larva will feed on the eggs, larvae, pupae, and young beetles of any species infesting the bark of pine and spruce trees. In fact, they are inclined to make themselves generally obnoxious to the little bark pests.

It would appear that all of the conditions necessery for the imported Clerid to multiply and become an efficient protector of our pine forests from future destructive invasions of bark beetles are most favorable. Dendroctonus frontalis, evidently the most destructive enemy of our pine forests, has, from some cause, been reduced far beyond its destructive powers. Other species which have depended upon it for the primary attack are, it would appear, somewhat demoralized on account of the disappearance of their benefactor. The large amount of felled timber found in the several lumbering regions will probably attract the larger portion of other threatening bark beetles away from the grcen trees, and by the time Dendroctonus frontalis can again marshal sufficient forces to successfully attack and kill the trees, they will, it is hoped, be met with a force of enemies led by the European bark beetle destroyer, which will succesfully 
repel them and thus save our forests in the future from destructive invasions of bark beetles." ***

OBSERVATIONS IN THE TIBBS RUN FOREST, MONONGALIA COUNTY.

This forest was visited on Sept. 24th, but no timber was found dying and no features observed worthy of mention here, except perhaps, the finding of a small pitch pine tree that had recently died from the attack of woodpeckers. Instead of the bird looking for insects, as is the habit of woodpeckers in general, it had evidently made the attack on the healthy tree for the sole purpose of feeding on the inner bark. Thus, instead of destroying insects, it had made the conditions favorable for the attack of bark beetles and other insects which had bred in the bark and wood in considerable numbers. In anticipation of some one thinking that it was the intention of the woodpecker to thus trap the insects and come back and collect them, I would say that at the time the observations were made, the insects had not been molested, and further, the injury done

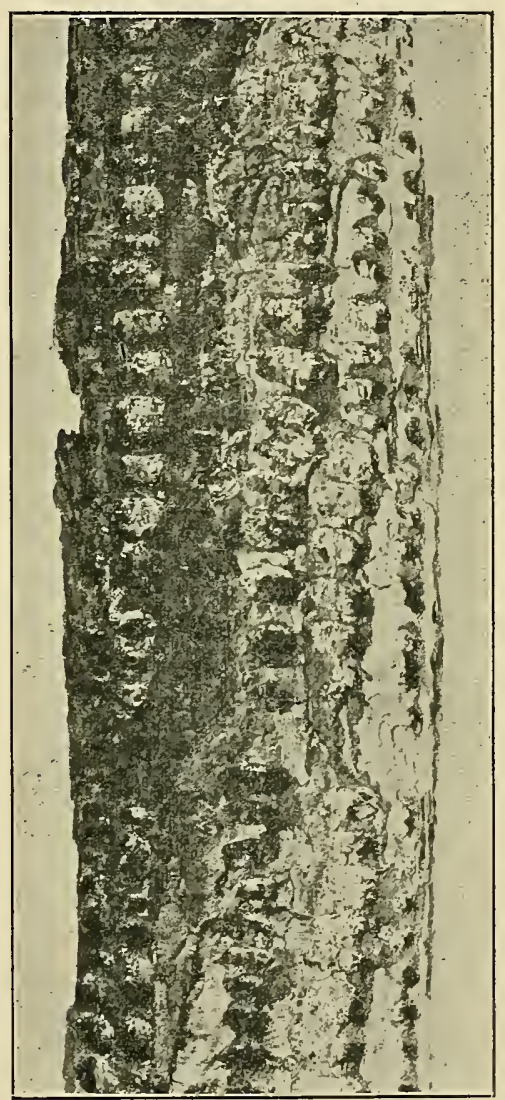

Fig. XLVI. Work of woodpeckers in young pitch pine. Tree died from injury. was evedently by the yellow bellied woodpecker or sapsucker, which prefers to feed upon the sap and inner bark of living trees and seldom, if ever, searches for insects in dead trees 
OBSERVATIONS IN RALEIGH COUNTY.

WHITE PINE.

This section was visited on Oct. 6 th, -7 th, where the conditions were found to be slightly clanged from that of the previous May. Very few trees had died since then, and although the turpentine beetle had developed broods in the living and injured trees, no serious damage had resulted; in fact, the healthy ones that were attacked in May by such numbers of this species as to make it seem impossible for them to recover, were found at this time to be apparently as healthy as they were previous to the attack. This bark beetie was also found in all stages of development in the bark of stumps of recently felled trees, and in one case a recently developed brood had died, apparently from a disease. Broods were not developed in all of the living trees attacked, since a great many trees were found which had been abandoned by the beetles apparently before eggs were deposited.

Two of the surviving species (Tomicus pini and Tomicus caelatus) were found to be exceedingly abundant,especially the latter, which occurred in all stages in the tops and logs of trees that had been felled during the previous spring. They were attacking the bark of recently felled trees, but not at this time so far as I observed, attacking living trees, or even those in which broods of the turpentine beetle had developed.

Another bark beetle (Hylastes cavernosus, Zimm), which had not been previously noted in the white pine was common, mining in the liviug bark on the roots of stumps of recently felled trees. Eggs occurred in their mines in considerable numbers, but no larvae were found.

Contrary to my expectations the conditions here were quite encouraging. The living timber had not been injured by the invasion of the turpentine bark beetle (Dendroctonus terebrans) and the two other common bark beetles (Tomicus pini and Tomicus caelatus) which it was feared during the previous May would attack the living and injured trees, had not done so. They had evidently been attracted to the tops and logs of the 
numerous trees that were being felled for saw logs, and thus the living timber had escaped.

OBSERVATIONS IN THE JAYFIELD HILL GROVE.

This piace was visited on Uct. $22 \mathrm{~d}$, where the turpentine bark beetle was found to have developed broods in the trees attacked during the spring and summer. In one interesting case a brood was found under the bark on a root six inches below the surface of the ground. They had recently changed from the pupae, but had not matured sufficiently to come ont. It was quite evident that they would not have matured suffciently to emerge before cold weather, and would have doubtless passed the winter in the position they were found, had they not been disurbed. ${ }^{1}$

The same Hylastes (Hylastes cavernosus) was found here as in the white pine in Raleigh. It was common in the bark of roots of trees that had died last spring where it had evidently bred.

No trees in this grove had died recently, and a number that had been invaded by the destructive bark beetle in the fall of $1892 \mathrm{had}$, to all appearances, entirely recovered.

This ended my observations with reference to the pine and spruce in 1893 , and in reviewing what I had recently found, I was ready to change my opinion, which I had previously held, about the destructive powers of the turpentine bark beetle (Dendroctonus terebrans), Tomicus pini and Tomicus caelatus, and had it not been for occasional rumors of new outbreaks of the trouble in different sections of the State, 2 I would have been ready to conclude that the trouble was at an end. In fact, so far as the destrucive bark beetle being concerned in a continuation of the trouble, I was well satisfied that nothing was to be feared.

conditions IN 1894.

The first observations made in 1894 was on April 13 th while in Doddridge county, near Central Station, where I found a small dying scrub pine which was infested by a small bark beetle (Pityophthorus pullus) which was entering the bark and

1 A new enemy of this insect was found here, namely, larva of an Elatrid beetle which was observed feeding on the pupae.

2 These reports referred to trees that were dying from previous injuries, as was sub sequentiy determined. 
depositing eggs, There was not sufficient evidence, however, that this or any other insect had caused the death of the tree.

Botween May 5th and 7th I made a trip by horse and buggy through Hampshire county, from Romney to Ice Mountain and returned by another route. This is distinctly a pine region where the scrub, pitch, yellow, table mountain and white pine all occur more or less common. Here a great amount of timber had died during the epidemic of 1892, but at the time of this visit, very few trees indeed were dying; no more in fact than would naturally occur in any pine forest.

\section{CONDITIONS IN THE SPRUCE.}

The spruce forest in Tucker county was visited on May 8th and 9th near Davis, where the spruce timber was found in a healthy condition. Here, as in the white pine, the extensive cutting of timber furnished an abundance of food and places to breed for the spruce bark beetles, in stumps, logs and tops, so that there was no occasion for them to attack the living trees.

The spruce forest near Pickens, in Randolph county, was visited on June $22 \mathrm{~d}$, and no spruce trees whatever were found dying. In fact, it was necessary on account of the absence of injured and recently felled trees, to girdle a number of trees in order to make the conditions favorable for the colony of Clerids that was located there. But very few trees had died fron the attack of the destructive bark beetle, in this isolated section of the spruce area.

\section{CONDITIONS IN THE MAYFIELD HILL GROVE.}

The Mayfield Hill Grove was visited on Sept. 2d when old mines of the destructive bark beetles were cut from some of the living trees that were covered by two annual growths or layers of wood, and the galleries of the turpentine bark beetle were found that had been covered with one layer.

One dying tree was found that bore evidence of having been killed by Tomicus calligraphus and Tomicus cacographus which occurred in the bark in large numbers, the parent beetles having entered the living bark, as indicated by the balls of turpentine. All of the other trees were, however, in a 
healthy condition. Even some of those which had been attacked by the destructive bark beetle in July, 1892, and the turpentine bark beetle in 1893 had entirely recovered.

CONDITIONS IN THE SOUTHERN AND SOUTHWESTERN PART OF THE STATE.

Between Oct. 6th and 15th an extended journey was made through the southern portion of the State, during which I passed through all of the counties bordering on the Ohio river below Parkersburg, and those joining Kentucky and Virginia on the extreme south; also through Mercer, Summers, Greenbrier and into Pocahontas.

The trouble was found to have extended through all of these western and southern counties wherever any of the pines grew, but at this time no dying timber was observed, with the exception of a few trees in Jackson county, which were infested with Tomicus calligraphus and T.aviulsus and showed indications of having been attacked when living; also a few white pine trees in Greenbrier county, which upon felling and making a thorough examination, were found to have

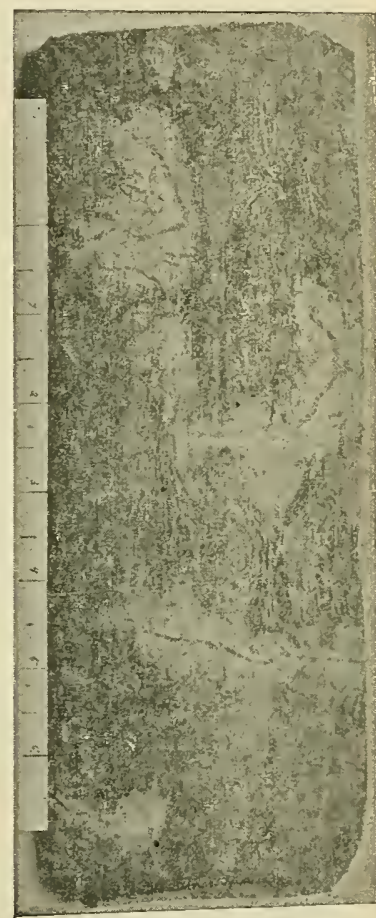

Fig. XLVII-Galleries of the destructive pine bark beetle made in living tree. Specimen taken from saw-log cut one or two years after the tree had died. been seriously injured in 1892 , by the destructive pine bark beetle and had been prevented from recovery by successive attacks of Tomicus pini and Tomicus calligraphus.

One large white pine near Mr. Kirkpatrick's on Anthony creek, ${ }^{\prime}$ in Greenbrier county, was found that had evidently died during the'past; summer. The top was dead and the? leaves turned red ; the bark on the lower portion of the trunk was liv: 
ing and infested at this point by both bark and timber beetles; the water or sap was runuing from the holes in the bark made by the timber beetles Gnathotrichus materiarius and Xyloterus

lineatus, which was a

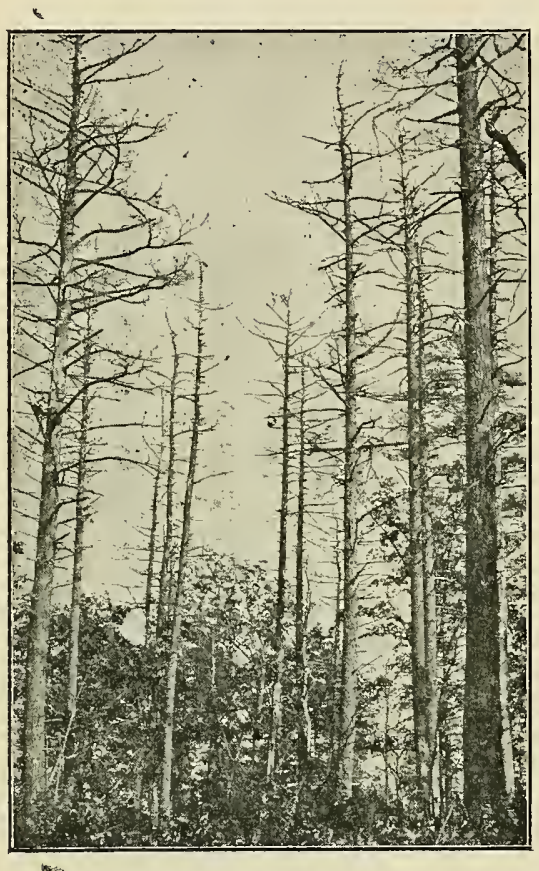

पित

Fig. XLVIII-Dead white pine timber, on Anthony's creek, Greenbrier county, in 1894, two or three years after it was killed by the destructive pine bark beetle.

feature I had not previously observed. I could flnd no satisfactory explanation of this rather remarkable and unnatural occurrence. Living and dying trees had been previously observed at almost all seasons of the year that were attacked in a similar manner, but while it was a common occurrence for the turpentine to flow from such wounds, at no time was the water or sap observed to flow. On the upper portion of the trunk of this tree numerous balls of turpentine were observed, thus indicating the presence of the destructive pine bark beetle. However, upon felling the tree and making a thorough examination, it was found that the fresh balls of turpentine were flowing from the entrance of brood galleries excavated by the large Tomicus calligraphus. Near the top at the usual point infested by the destructive bark beetles, it was found that a brood of Tomicus pini had developed and many of the adults had emerged. The bark was dead and mined in all directions by the parent beetles and their young. Old galleries of the destructive pine bark beetles were found in the inner bark and old balls of turpentine 


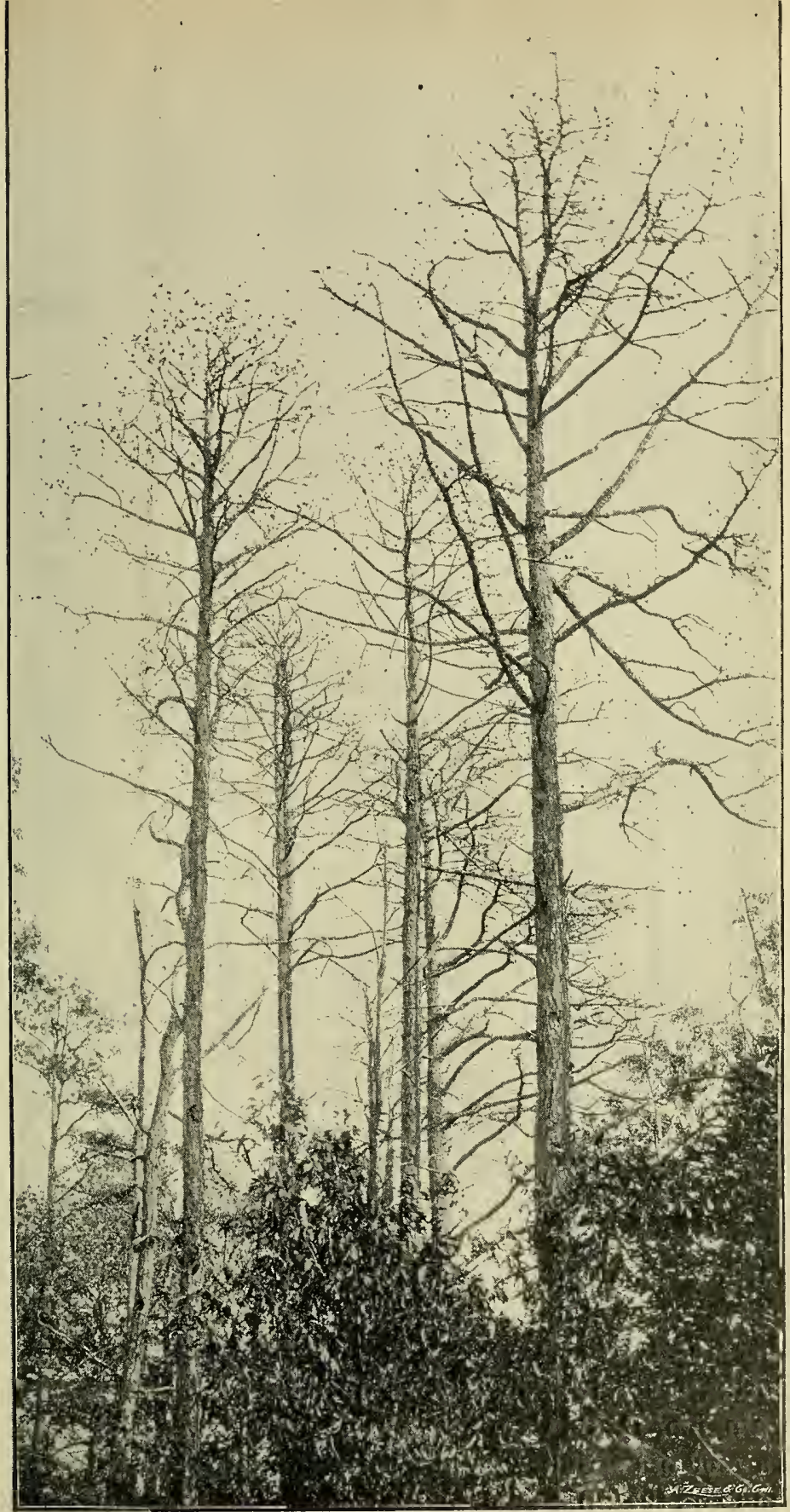

Fig. XLIX...White pine timbor killed by the destructive pinẹ bark beetle. Condition in get. 1894; trees died in 1891-3 ; 
occurred on the surface, showing that the tree had been attacked by this species, evidently in 1892 , and that the vitality of the tree had thus been weakened. The turpentine bark beetle, Dendroctonus terebrans, had attacked and bred in the bark at the base of the tree in 1893, and Tomicus pini had attacked the top early in the spring of 1894. Tomicus calligraphus had atiacked the remaining portion of the trunk during the summer, thus, we had here a typical example of what was expected to happen to all of the living trees, when in the spring, 1893, I found that the destructive bark beetle was dead and the turpentine bark beetle was attacking the living trees, and several species of Tomicus and other bark and timber beetles were also abundant. Why more of the living timber was not attacked may, perhaps,be explained by the fact that the great quantities of timber felled in lumbering regions had attracted the beetles away from the living timber, the tops and logs and stumps offering more favorable opportunities for them to breed than did the living trees. The trees on Anthony creek, however, indicated what might have occurred under different circumstances. No timber was being felled in the immediate locality which in part would explain the cause of the attack on this and other injured trees. A few other trees were found in the same locality, but since they were surrounded by trees that had died in 1891-2, it was evident that they had been injured when the other trees were invaded by the destructive bark beetle.

Some of the white pine trees that had died in 1891 were examined, and while the sap wood was found to be decaying and worthless, the heart wood was sound and clear, and with the exception of a few worm holes, would have made a very good grade of lumber.

Further examination of the white pine, as well as the scrub, pitch and yellow pine in this section, showed that very little timber was dying.

During my return by rail to Morgantown, bv the way of Washington, D. C., Cumberland, Md., and Connelsville, Pa., I had a good opportunity of observing the general conditions of the pine on the hills and mountain sides visible from the car 
window, through Virginia and portions of Maryland and Pennsylvania. From the healthy appearance of the pine through West Virginia and the other States mentioned, and from a careful examination of such trees as were found in an extended journey by horse and buggy through the pine areas of the southern counties of West Virginia, I was convinced that but little, if any, pine timber was then dying, or had died from insect attack during the spring and summer of 1894. In fact, all of the evidence found plainly indicated that the trouble caused by the destructive beetle was at an end. It also appeared that none of the other pine infesting bark beetles alone, or all in combined forces, were capable of continuing the trouble, which it seemed, from the conditions existing in the spring of 1893 , they must continue to do.

The destructive bark beetle (Dendroctonus frontalis) had apparently been completely exterminated in all sections of the vast area invaded by it in $\mathbf{1} 890$ to $\mathbf{1 8 9 2}$, since not a single living example had been seen by me or authentically reported within the area north of the Carolinas since the fall of 1892.

The spruce forest in Tucker and Randolph counties were visited by me on Oct. 22d-23d, 1894, and here, as in the pine areas, the timber was in a healthy condition, scarcely a tree could be found that was dying. The spruce bark beetle occurred in great numbers in logs and tops of felled trees, but were not attacking the living trees, and so far as I can learn, had not attacked any except those that had been injured.

Upon my return to Morgantown 1 notified the owners of tim ber of the encouraging conditions that I had found, and sent the following notice to the principal timber journals of the country and newspapers of the State.

A SERIOUS TROUBLE OVER.

No More Pine and Spruce Timber Dying in the Virginias from the Attack of Insécts.

"It may be of interest to your readers to learn that the serious trouble, which in 1890-92 threatened the entire destruction of the valuable pine and black spruce forests in West Virginia and adjoining States is entirely over.

I have just returned from a thorough survey of the affected territory, 
having traveled over two thousand miles through West Virginia, Virginia, Maryland and Pennsylvania, and have gone into the heart of the white pine and spruce regions in West Virginia, where I carefully examined every tree that I found showing the least indication of disease. After thus thoroughly examining into the condition of the timber, I am confident that there is no spruce or pine dying in West Virginia, at least, from the attack of insects. I am all the more convinced that this is so frum the fact that I have not been able to find a single living example of the destructive pine bark beetle (Dendroctonus frontalis) in the State since the spring of 1893 . As this inseet was the real cause of the trouble referred to, I think I am perfectly safe in saying that it will be many years before it is capable of making another destructive invasion, if it ever does.

While a large amount of timber was killed by the bark beetle in West Virginia, their remain large quantities of healthy timber in this State, especially of spruce. A large per cent of the yellow, scrub and pitch pine was killed, but a much less per cent of the white pine, and only a small per cent of the black spruce died.

I am glad to note that much of the white pine, and I may say nearly all the spruce that was killed by the bark beetle in 1891-2 is yet in a condition to make good second and common grades of lumber, and I think most of it, especially the spruce, will remain in about the same condition for one or two years; therefore there will be an opportunity to save some of it.

(Signed) A. D. Hopkins,

Ent. W. Va. Experiment Station.

Morgantown, W. Va. Nov., 1894.

\section{OBSERVATIONS IN 1895-6.}

Owing to the fact that the trouble which had affected the pine and the spruce was considered to be over, and that I had turned my attention to other lines of investigation, few observations were made in 1895 , and I have only two or three that may be worthy of mention in this connection.

While in the Tibb's run forest on Oct. 29th, 1895, a dying pitch pine was pointed out to me, which upon examination was found to be infested with Tomicus calligraphus, which, as indicated by the balls of turpentine on the bark, had attacked the tree while the bark was living. Two other trees were found on July $2 d$ about a half a mile or more from this one, One of these was felled and examined and it was found to be infested with bark beetles, but showed no indications that it had been attacked while living. A small bark beetle, ${ }_{, 1}$ which makes galleries similar to that of the destructive bark beetle, was especially common, One of the smallest species of the bark 
beetle (Crypturgus pusillus) was also common. Since no other trees were dying here at the time, and none have died since, the trees had evidently been affected by some primary cause other than the attack of bark beetles.

On Dec. 15th I found several pitch pine trees dying in the midst of a large grove of trees that died in 1892 from the attack of the destructive pine bark beetle. Upon examination these trees were found to be infested with Iomicus calligraphus and the same species of small bark beetle found in the dying trees at Tibb's run. namely Pityophthorus confinis. Iomicus calligraphus had entered the living bark and apparently the second brood had developed in the tree; the first in the bark on the upper portion of the trunk, and the other in the bark lower down. It was evident, however, that this and the other trees had been previously injured and had gradually succumbed to successive attacks of bark beetles

In January, 1896, a piece of wood and bark was received from Mr. Taylor E. Hiett, which had been cut from a dying tree in a section where it had been reported that the timber was dying as it did in 1892. An example of Tomicus calligraphus was found in the bark which it had entered while the bark was living. I was informed by Mr. Hiett, however, that but few trees had died and they were near the groups of trees that were killed during the epidemic of 1892.

No further observations having a bearing upon the subject under consideration were made during 1895-6, and it is evident that no timber of any consequence has been dying in any of the principal pine and spruce regions, or I would have been informed of it. It is therefore evident from recent observations, and the absence of complaint, that at present the conditions in the pine and spruce forests, so far as injury by insects is concerned, is normal.

\section{SUMMARY OF OBSERVATIONS AND CONCLUSIONS.-1893-6.}

In a review of the observations from 1893 to 1896 , noted in the preceding pages, the following summary of the facts and conclusions is made: 
NO LIVING EXAMPLE OF THE DESTRUCTIVE SPECIES FOUND.

No living examples of the insect (Dendroctonus frontalis) which was the cause of such widespread devastation in the pine and spruce forests of West Virginia and adjoining States, between 1890 and the fall of 1892 , could be found in the early

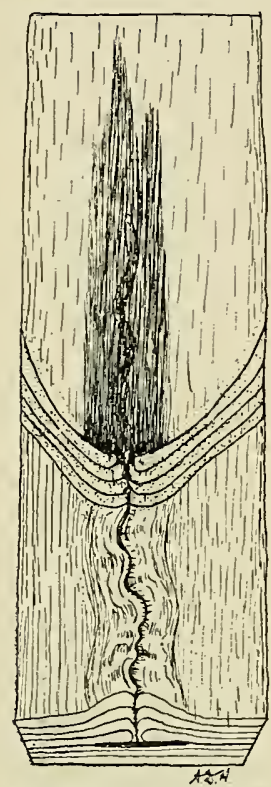

Fig. L-Gallery of Dendroctonus frontatis, made in living tree, covered by four years growth of wood. spring of 1893 , and none to my knowledge have been observed or reported from the effected area north of the Carolinas to the present date, Dec. 1st, 1896.1

OTHER BARK BEETLES WERE NOT EXTERMINATED.

The numerous allies of the destructive pine bark beetle, in causing the death of the trees and destruction of the wood, were not, with one exception, injured by the causes or conditions which resulted in the extermination of their benefactor.

$$
\text { SWARMS OF BARK BEETLES. }
$$

Great migrating swarms of the surviving species of bark and timber beetles accompanied by predaceous enemies, occurred during the last of April and first of May, 1893 , throughout the principal pine and spruce areas of the State. The large turpentine bark beetle Dendroctonus terebrans occurring in far greater numbers than any other species.

A NEW TROUBLE THREATENED BY THE SWARMS.

The turpentine bark beetle ( $D$. terebrans) invaded living pines of all species, and the Norway spruce in May,1893, entering the bark at the base of the trees. This fact, together with the excessive numbers of other threatening bark beetles, indicated that the timber would continue to die from their combined attack. 
TREES ATTACKED BY OTHER BARK BEETLES DID NOT DIE.

In 1894, it was found that the living, healthy trees attacked by $D$. terebrans in 1893 , and threatened by other bark beetles, did not die, and the vitality of the trees was not impaired by the attack.

\section{THE TROUBLE ENDED.}

The trees that were seriously injured by the destructive bark beetle (Dendroctonus frontalis) in 18912 and did not die then, gradually died during 1893.6, the larger number dying in 1893 and fewer each subsequent year until 1896, when but very few trees died, and with them the last effects of the work of the destructive bark beetle upon the living trees was obliterated, except the defects in the wood which will be found in trees that were attacked and are now living.

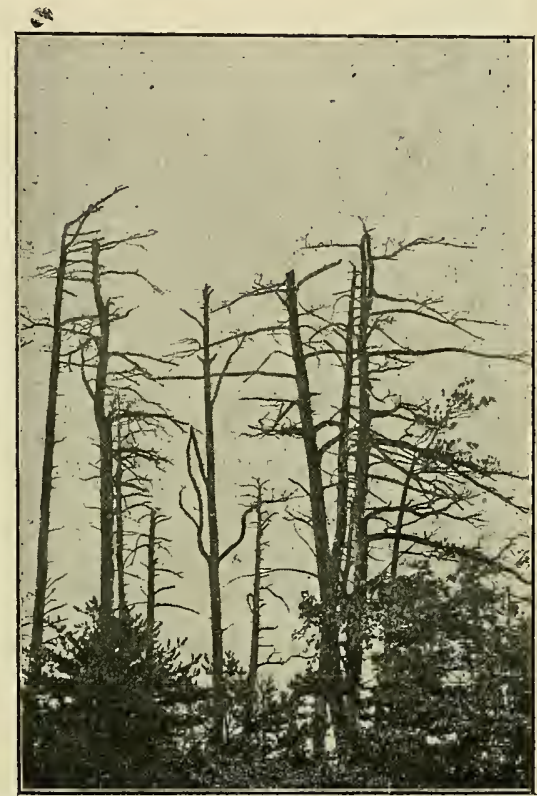

Fig. LI.-Table mountain pine on Allegheny front, Mineral county ; seven years after it was killed by the destructive pine bark beetle.

CONCLUSIONS.

THE CAUSE OE THE TROUBLE.

The cause of widespread devastation in the pine and spruce timber in 1890 to 92 was the primary attack upon living trees by swarms of the destrnctive pine bark beetle Dendroctonus frontalis.

WHEN THE DESTRUCTIVE BARK BEETLE DISAPPEARED THE TIMBER CEASED DYING.

The cause of the cessation of the trouble was the death of 
all stages and examples of the destructive bark beetle, in the winter of I892-3 throughout the infested area.

The apparent con-

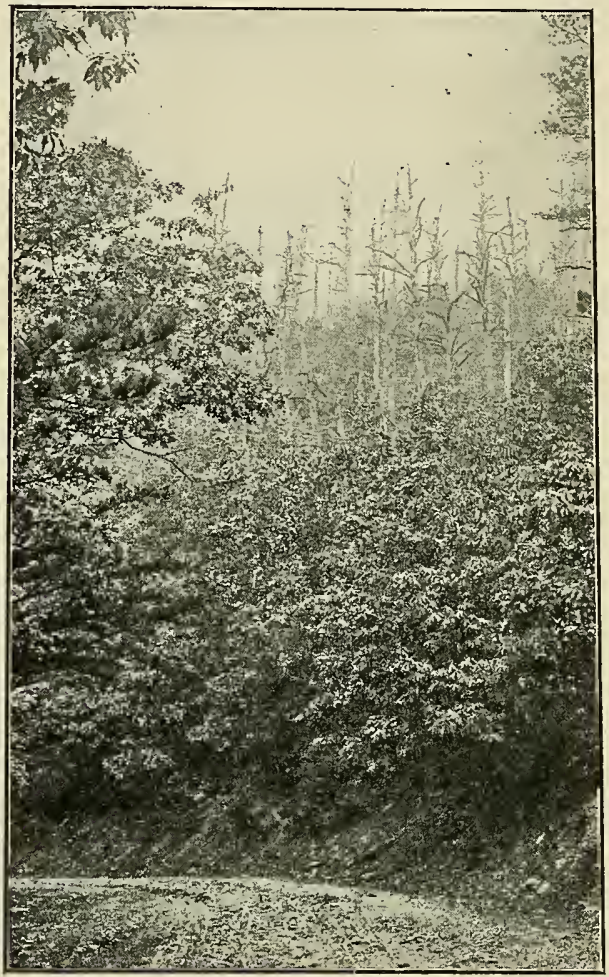

Fig. LII.-A forest of table mountain pine on north western turnpike, Allegheny front. Seven years after it was killed by the destructive pine bark beetle. tinuation of the trouble to 1896 was simply the gradual dying of injured trees from subsequent and successive attacks of other species of bark beetle, which prefer to attack injured, diseased or felled trees.

FURTHER TROUBLE PREVFNTED.

The attack on the remaining healthy pine and spruce by the surviving species of bark beetles, which were capable of attacking and killing trees, was evidently prevented by the common occurrence of injured trees in the spring

of 1893 , and the great quantity of tops, logs and stumps of recently felled trees that subsequently occurred in the numerous lumbering regions throughout the pine and spruce area, which attracted the threatening beetles away from the living timber.

AREA INVADED BY THE DESTRUCTIVE BARK BEETLE.

As near as I can ascertain, che total area, including portions of West Virginia, Virginia, Maryland, Pennsylvania, and pro 
bably New Jersey ${ }^{1}$ in which more or less pine or spruce died during 1891-2 evidently from the invasion of Dendroctonus frontalis is something over 50,000 square miles. And doubtless the total area in which a greater or less number of coniferous trees were killed by the insect, if the facts could be learned would make the total invaded area north of the southern borders of Virginia and West Virginia, at least 75,000 square miles.

In West Virginia alone, the infested area included about 15,000 square miles, and it is very evident that whatever conifers grew in any quantity in Virginia, Maryland and southern Pensylvania, the insect made its presence known by conspicuous groups of dying trees.

TWO REMARKABLE FEATURES OF THE INVASION.

Although Dendroctonus frontalis has been recorded from New Brunswick to Georgia, and from the Atlantic to the Paci. fic coasts, it had been, previous to 1590 ,considered a rare species and was represented in but few collections in this country and Europe. That it should make its appearance within a few years in sufficient numbers to take the character of an invasion, attack and kill pine and spruce timber upon thousands of square miles, and threatening the total destruction of the coniferous forest and shade trees of the eastern United States, was a most remarkable occurrence.

This sudden appearance of the species in such destructive numbers, followed by its sudden and universal death over the vast area, mentioned, were in fact $t$ w o remarkable occurrences the equal of which has probably never been recorded.

Devastating invasions by locusts, chinch bugs, army worms, and forest insects, have been recorded from time to time, but in most cases if not all, I believe, so far as noted, the invading

1. I have not conducted investigations in Virginia, Maryland, Pennsylvania, or New Jersey ، but from car window observations and information with reference to the dying of pine trees in these states in the same way, and during the same period, as in West Virginia, I am confldent that it was from this same cause. 
insects were common, or at least not rare, both before the be ginning and after the ending of the destructive outbreak; but in this case the insect was apparently exceedingly rare before the beginning ; and apparently extinct in the invaded territory after the ending of the trouble caused by it.

When we come to consider the causes of the sudden death of the insect over such a vast area, including such widely varying conditions of altitude and climatic conditions, we have at once a complicated and difficult problem to solve.

ON THE CAUSES OF THE UNIVERSAL DEATH OF THE INSECT.

The sudden and universal death of the destructive pine bark beetle throughout the State, in the winter and spring of 18.93 , was a most fortunate occurrence, and at the same time a most remarkable one, not easy to explain. It was as if a supreme power, dissatisfied with the undue increase of the species and the widespread devastations wrought by it, had sent a plague to exterminate it. In fast it is apparently the rule that, when an animal of almost any species increases to excessive abundance, it is, sooner or later, reduced to its normal position by its natural enemies, parasitic and predaceous iusects, or unfavorable climatic conditions, or all combined.

It is evident that the extermination of the destructive pine bark beetle was brought about by one or more of these causes, which we will discuss separately.

\section{CLIMATIC CONDITIONS.}

My first conclusion upon finding the insect dead in the bark of trees examined in the early spring of 1893 , was that they had been killed by the excessive cold of the previous winter; and from the records of the temperature by the Weather Bureau of the Department of Agriculture, in the annual summaries of

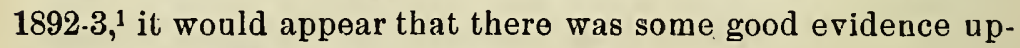
on which to base this conclusion.

1. Table of maxium and minimun temperature Dec. 1892 and 1893. 
In 1892 the recorded maximum and minimun temperature within the infested area, during the month of December was as follows : 1

The maximum ranged from $67^{\circ}$ at Washington, D. C., to $71^{\circ}$ at Richmond, Va., and the minimum from $17^{\circ}$ above zero at Bedford Oity, Virginia, to $13^{\circ}$ below at Ligonier, $\mathrm{Pa}$, and $10^{\circ}$ below at Buckhannon, W. Va.

In 1893 the maximum ranged from $54^{\circ}$ at Imlaystown and Whiting, in N. J., to $77^{\circ}$ at Ashland, Virginia.

The minimum ranged from $4^{\circ}$ below zero at Cambridge, $\mathrm{Md}$., to $26^{\circ}$ below at Big Stone Gap, Virginia, and Oakland, Md., and $25^{\circ}$ below at Spencer, W. Va., and Saegerstown, Pennsylvania. The lowest minimums ranging trom $6^{\circ}$ below at Receiving Reservoir, D. C., to $26^{\circ}$ below at Big Stone Gap, Va., and Oakland, Md.

During the first week in January there was exceedingly cold weather throughout the area. The thermometer fell below zero at all of the U. S. Weather Bureau Stations in Maryland. New Jersey, Pennsylvania, Virginia, West Virginia and D. C., except at Cape Henry and Norfolk, Va.

1. TABLE OF TEMPERATURE DECEMBER, 1892 ; JANUARY, 1893.

DECEMBER, 1892.

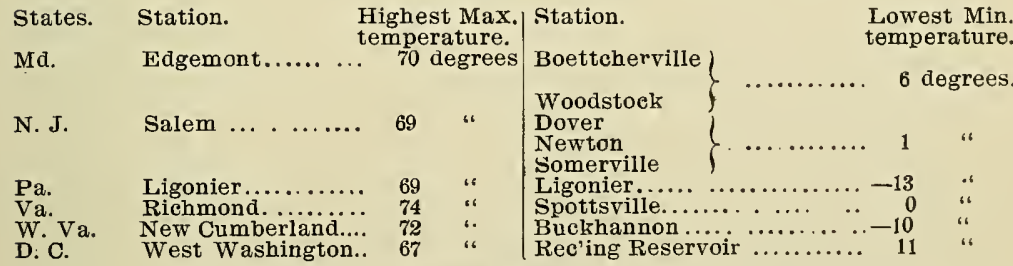

JANURARY 1893.

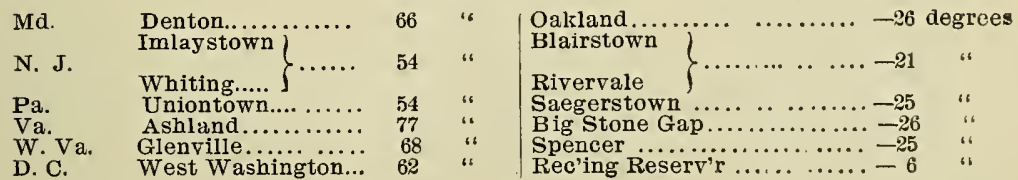


It will be seen from the above records, that with the exception of a local cold spell in Penusylvania in January, 1892, the lowest temperature throughout the infested area for two years ${ }^{1}$ was late in December, 1892, and early in January, 1893, when the mercury fell to $17^{\circ}$ below zero in Maryland, $21^{\circ}$ below in New Jersey, $25^{\circ}$ below in Pennsylvania and West Virginia, $26^{\circ}$ below in Virginia and $6^{\circ}$ below in the District of Columbia.

In 1890, the minimum at the different Stations in the States mentioued above, ranged from $22^{\circ}$ above at Fortress Monroe, in Virginia, to $18^{\circ}$ below at Charlesville, in Pennsylvania, and $14^{\circ}$ below at Tannery, in West Virginia; all in the month of March. In 1891 , the minimum in the same states ranged from $19^{\circ}$ above at Birdsnest, Va., in December, to $14^{\mathrm{u}}$ below at Corry, and Dyberry, Pennsylvania, in March, and $9^{\circ}$ below at Pleasant Hill, West Virginia, in the same month.

The lowest temperature recorded from West Virginia in 1890-3 was $14^{\circ}$ helow zero in March, $1890 ; 9^{\circ}$ below zero in March, $1891,10^{\circ}$ below in December, 1892 , and $25^{\circ}$ below in January, 1893.

The excessive cold weather throughout the infested area during the last days of December, 1892, and first days of January, 1893, it would appear, was sufficient to kill the insects if it were possible for them to be killed by cold. And the fact that this was the coldest weather that had been recorded throughout the infested region since the trouble commenced, and that it was followed by the extermination of the insect, is evidence that the death of all of the individuals of this species was due to unfavorable climatic cunditions. ${ }^{2}$ But when we come to consiaer that the other species of bark beetles wilich were associated with Dendroctonus frontalis in the same trees and the same bark were not kilied, it would appear that if the death of one species was caused by climatic conditions, the others would have suffered also. Many examples of the turpentine beetle, Dendroctonus terebrans, (which does not associate wilh Den-

1 Probably the lowest since 1885-6. See Annual ${ }^{\circ}$ Summary for 1892.

2 "Nothing is better known than that exceptional freezes may kill off thousands of in. sects; there must therefore be species whose successful hibernation is limited by certain degrees of cold." L. O. Howard, Pro. Ent. So. W. Vol. III, No. 4. p 225. 
droctonus frontalis) were killed when different stages occurred in the bark some distance above the base of the tree; but Tomicus pini, Tomicus calligraphus, Tomicus cacographus and Tomicus caelatus, which often occurred in the same.bark with the destructive species and pass the winter in the adult stage in the bark or in the wood and bark of small twigs, were not affected in the least so far as I could observe; neither were species of the genus Pityophthorus, Pityogenes, Polygraphus and Crypturgus, the latter being among the smallest of all the bark beetles. All of these pass the winter in the adult, and some of them in all stages except the eggs, in the same manner as did Dendroctonus frontalis. Polygraphus rufipennis may be found in all stages in spruce bark during the winter, which was not apparently affected in the least by the cold, even on our higher mountains where it was probably much colder than at a place where the temperature was recorded.

Insects, and especially bark beetles, are capable of withstanding a very low degree of temperature within their natural hibernating places, yet sudden changes from low to high temperature, or the reverse,may, and doubtless does kill enormous numbers of insects of various kinds. ${ }^{1}$ In the case of southern species extending northward during a series of mild winters, I should not be surprised if a period of excessive cold temperature would exterminate them north of their natural limit. Pessibly some species of wide range of destruction over different zones of temperature may be less capable of resisting extreme cold or sudden changes than those which are confined to a restricted area where extremes of temperature occur, but it does not seem probable that this would be the case.

It is not possible, from our present knowledge of the destructive pine bark beetle, to say whether or not it has extended its range of destruction from the south or from the north; but the fact that it has been taken in the northern, eastern, western, and southern portion of the United States, would indicate that it is a species which is capable of existing under 
widely varying climatic conditions. If, however, the devastation was caused by a southern variety of race, and from its migratory habits extends northward only as opportunity offers, it would doubtless be killed by excessive low temperature; but if it were a species which has long been established in the northern sections of the United States and Canada, I doubt the possibility of its being killed by the cold.

Therefore, while I was led to believe, in May, 1893, when so many examples of this species were found to be dead, that their death had been caused by the severe cold of the previous winter, I was subsequently led to believe that unfavorable climatic conditions was not sufficient in itself, to cause the extermination of the species. Therefore, evidences of other causes were looked for and considered.

\section{INSECT DISEASES.}

If the insect was not killed by freezing or other unfavorable climatic conditions, it was evidently killed by a disease or diseases. During my investigations in Hampshire counly, in May, 1592, I discovered that many of the adults of the beetle were covered with a white mealy substance, which indicated that a fungus disease was attacking the insect. This same condition was frequently met with during subsequent investigations. Specimens of the beetles so affected were sent, through Dr. C. F. Millpaugh, to Prof. Peck, of Albany, N. Y.,for identification; who found that it was a new fungus of the family Tuberculaniaceae, and named it Cylindrocola dendroctoni. ${ }^{1}$ This disease was found to occur quite frequently in different sections of the State during subsequent investigations in 1892; but never common enough in the form in which it was first recognized, to indicate that it would produce an epidemic. The easily recognized character of the disease is a creamy white mealy sub. stance, covering the bodies of dead beetles, and lining the walls of the galleries in front and behind the dead insect.

Later in the summer and fall of the same year I observed that both the adults and larvae were dead in some of the in- 
fosted trees, but the bodies of the dead specimens were not covered by the white substance. 'This was thought at the time, to be due to some unfavorable conditions of the infested bark, and was not carefully studied Subsequent observations lead me to believe that this was also due to a disease; either an unrecognized form or stage of the new fungus determined by Prof. Peck, or was most likely caused by an entirely different fungus or bacterium.

These two characteristic conditions were occasionally met with in 1892 , in all of the regions of the State in which I conducted investigations, except in the spruce where nothing but the adult and egg stages were observed, ${ }^{1}$ and here many of the adults were dead in their bark galleries, some surrounded by the white substance, while others were not.

It would appear, therefore, that one or more kind of diseases were quite thoroughly distributed over the infested area, and that the insect had commenced to die, and many individuals of the species had perished, before cold weather set, in in December, 1892. In fact the diseases (if diseases were the cause of the extermination of the species) must have assumed by this tome, sufficient proportions to have infested all, or nearly all living examples before they ceased work and became dormant. If so. the first warm, sultry days of spring following a severe winter would have offered the most favorable conditions for the rapid development of the disease or diseases into an epidemic, which might soon exterminate the species in all of the area within its range. The conditions found in the spring of 1893 wonld indicate that this might have been the case. As previously stated, dead examples of the insect in all stages were found in great numbers in all of the infested trees that were examined during April, May and June, 1893.

The dead larvae and pupae had every appearance of insects that had died from a bracterium disease. Most of them found in April and May had turned black and were in an advanced stage of decay; the internal structure having been converted into a

1. Subsequently, bark was taken from dead spruce trees showing the larval galleries and pupa chambers of the species. 
dark semi-liquid mass which gave off a repulsive odor when the body wall was broken. 1

Many examples of both larvae and pupae were found in May which had apparently died quite recently; since they had, at that time, the normal whitish color. The body was greatly extended as if inflated with air, and upon breaking the skin, the internal structure was found to be decomposed. Therefore, while the severe cold of December, 1892, and January, 1893, and subsequent changes in temperature weakened the vitality of the insect, and must have killed many of them outright, the extermination of the species over such a vast area, was doubtless made doubly sure by the action of one or more contageous diseases which found the conditions especially favorable for its spread in the weakened vitality of the larvae and pupae that survived the winter.

That a disease alone could accomplish this end appears all the more probable, when we consider how epidemics among other kinds of insects known to be due to diseases almost exterminate the species over vast areas.

The chinch bug is attacked by a disease, which, under favorable climatic conditions, as continued wet weather, is practically exterminated over extensive areas within a few days. In fact, the disease may be successfully transmitted by artificial means from a locality or region where it is prevalent, to one in which it has not manifested itself; and thus produce an epidemic that spreads with remarkable rapidity. The disease of the clover leaf beetle is perhaps the most remarkable example of the effects of the disease upon insects. The clover leaf beetle (Phytonomus punctatus, Fab.,) is a native of Europe; but has become widely distributed over the northern and eastern United States. It is capable of enormous increase from a comparatively few surviving individuals; and we often find in the early spring, that the total destruction of the clover crop over vast area of country, is threatened by myriads of small

1. The same condition has since been observed with examples of larvae of scolytus rugulosus, Pityophthorus minutissimus and Chramesus icoriae which were known to be killed by freezing. 
green worms (the larvae of the clover leaf beetle) which are stripping the clover plant of its leaves and stems. They appear like a vast invading army of insect destroyers against which it appears useless for human effort to contend. Yet within a few days they are all dead over the entire infested area, as if by a blighting wind; and the clover plant soon recovers and goes on growing as if nothing had happened.

This disease appears to follow the beetle wherever it goes; and so sudden and effectual is its effect, that but few of the insects escape. These deposit eggs for another brood which in turn suffers from the disease, and so on. Year after year the disease appears and prevents the total destruction of the clover crop.

As an example of the action of a similar disease to that of the clover leaf beetle on forest tree caterpillars, I may mention here an interesting observation in Greenbrier county, in July, 1893, where on Cranberry Mountain in the midst of a vast hardwood forest, all kinds of trees and shrubs were completely defoliated by a small measuring worm (Geometrid). Hundreds of dead caterpillars were observed on all sides, clinging to twigs, partly eaten leaves, and the bark of the trees. A few living examples were found and placed in tin boxes for specimens and to breed the adult; but all were dead within a few days, and had the characteristic appearance of caterpillars that die from disease. Thus it was evident that the ravages of the insect had been suddenly brought to an end by the disease. The forest growth on one hundred acres or more in one place, had been defoliated by the insects which had apparently spread from central points of infection; so that the sudden disappearance of the caterpillars left a destinct line of demarkation be. tween the defoliated area and the unaffected portion of the forest. The defoliated portion having the appearance of a forest in winter, while the other was in full leaf. In this respect, the work of the caterpillars resembled one of the characteristic features of the trouble caused by the destructive pine bark beetle, 'which appeared to concentrate its forces on a few trees 
on a given area on which all trees were killed, the line between the dead and living timber being distinctly marked.

It was often noted during $m y$ investigations of the work of the destructive pine bark beetle, that many of these patches of dead timber were not extended after the first attack. These sudden checks to the spread of the trouble from central points of infection, were quite puzzling features. It was thought at first, that it was due to the multiplication of parasitic and predaceous enemies; but none of this class of enemies were subsequently found at any time in sufficient numbers to make this seem possilule.

\section{PARASITIC AND PREDACEOUS ENEMIES.}

In the early part of the season of 1892 , but few parasitic or predaceous enemies of Dendroctonus frontalis and of other associated species of bark beetle were found. Later in the summer they were more common, and in the fall they became quite abundant. These enemies doubtless, exerted considerable influence in weakening the force of the attacking hosts of the destructive bark beetle and its allies; but they can not be credited with the extermination of this destructive species.

\section{CONCLUSION.}

In a review of all the evidence $I$ have been able to bring to bear upon the subject of the causes of the sudden extermination of Dendroctonus frontalis in this State, I am ready to conclude that it was due to climatic conditions and the action of one or more contageous diseases. 
SOME OF THE PRINCIPAL INSECTS ASSOCIATED WITH THE PINE TROUBLE.

The Scolytids.

Order Coleoperra, Family Scolytidae.

The insect which was primarily to blame for the devastations in the pine and spruce forests in 1890 to 1892 , as well as a number of its principal allies in attacking and killing the trees and the subsequent destruction of the wood belongs to the family of beetles known as Scolytirlae: a family which is of special importance and interest on account of the destructive habits of a number of its representatives; especialiy in their relation to forest, sisade, and fruit trees.

SOME GENERAL FEATUKES AND HABITS OF THE FAMILY.

All of the individuals belonging :0 the family Scolytidae have the same general appearance as those illustrated and described on the following pages. Of the 160 or more species that are known to occur in America, north of Mexico, Dendroctonus terebrans, Fig. LXXII, is the largest and Crypturgus pusillus is among the smallest examples.

\section{GEN $\because$ RAL HABITS.}

They infest, as a rule, the bark and wood of I rees and shrubs; but some of the species attack the roots and stems of herbaceous plants, while a few are found in seeds and dried vegetable matter.

THEIR PREFERENCE FOR CONIFEROUS TREES.

A large number of species prefer to attack and breed in con. iferous trees; but almost all kinds of trees and shrubs are infested by one or more species, and some species infest a great variety of trees. The oaks, hickories, tulip, beech, ash, elm, maple, red-bud, and sumach are attacked, as are the different kinds of fruit trees; but the pines are their special favorites, since more than one-fourth of the entire known species in this 
country infest this class of trees. Every part of a pine tree may be attacked by one or more species from the roots to the terminal twigs, and even the cones. A large number enter and breed in the bark alone; while others may occupy both the bark and wood, and a number of species enter and breed in the wood alone.

GROUPED ACCORDING TO HABIT.

Species which breed in the bark of the roots, trunk and branches, are called bark beetles. Those which enter the wood direct, are called timber beetles or ambrosia beetles, while those which infest the bark or wood of the twigs, are called twig beetles.

Some of the species of the family prefer to enter the bark or wood of living trees, in fact there are a few which will attack none but living trees. There are others which are capable of attacking and mining in the lising bark and wood, but prefer to infest that of recently felled, injured and dying trees; the partly living bark of which, offers the most favorable condition for the development of their broods. This class of Scolytids, which are by far the most numerous, will not attack healthy living trees if unhealthy or felled ones are to be found.

There is still another class represented by numerous species which never attack living trees, but infest the bark and wood after it is dead, and in some cases after it is dry and seasoned.

The class of Scolytids which attack healthy living trees and cause their death by mining under the bark; and those which render the partly living or sound wood worthless by their galleries and attending stained streaks or rapid decay, are termed destructive scolytids. Those which attack only diseased, injured, or felled trees, or merely hasten the death of those attacked by other species, are termed allies of the destructive species or simply injurious scolytids. While those which infest only the dead bark, wood, or twigs, may be relerred to as neutral scolytids, since they are neither destructive nor injurious to a commercial product. They may also be grouped according to the character of their attack as those making the 
primary attack, those making a secondary attack and those which are dependent upon other species to make an entrance in the bark, and otherwise produce favorable conditions for the development of their broods.

THE MINES OR GALLERIES.

The Scolytids differ in their breeding habits from nearly all of the other bark and wood infesting insects, in the fact that the adults bore directly into the bark or wood and form mines or galleries in which their eggs are deposited. Each species or group of nearly related species, as a genus, not only have a characteristic methor of attack, but excavate their galleries according to some more or less uniform plan, or pattern, by which alone the species or genus may often be determined.

The different parts of these galleries, excavated by the parent beetles and their young or larvae, are designated by the following nomenclature:

The main entrance is the first entrance made by the parent beetle in the bark or wood. Those excavated by the bark beetle extends to the inner bark or surface of the sapwood where they open into the nuptial chamber, or branch off into one or more galleries. 'Those excavated by ambrosia beetles extend directly through the bark and into the wood.

Side entrances and exits are passages extending from the primary gallery to the surface of the bark.

The nuptial chamber. This is a large space at the inner end of the main entrance, to the galleries of so-

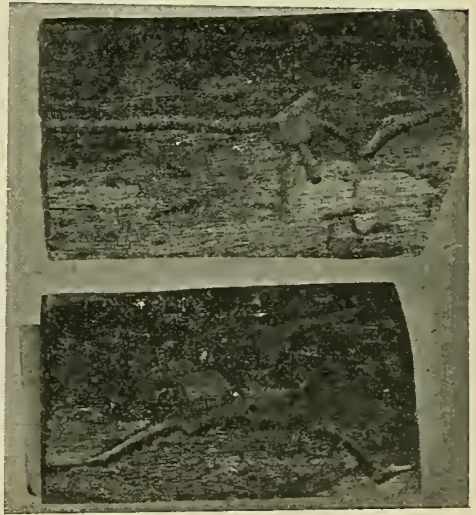

Fig. LIII. Nuptial chambers of Tomicus cacographus in pine. cial species of both bark and timber beetles, which is utilized as a kind of reception chamber for the sexes, and as a central court from which the primary galleries extend. 


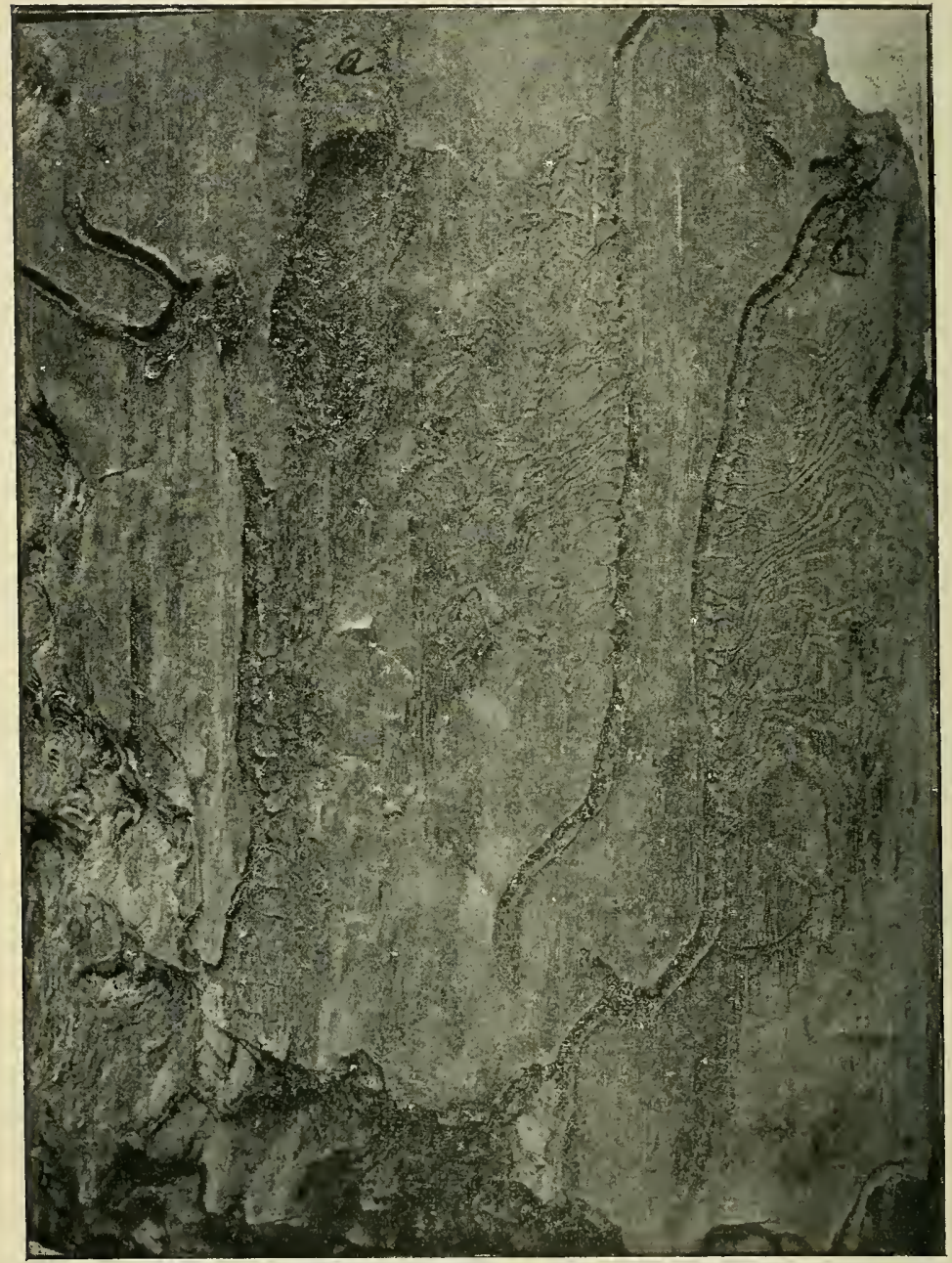

,

Fig. LIV---Galleries of Tomicus calligraphus, in yellow pine bark, showing in telligence of beetles, inidepositing eggs on opposite side of parallel galleries $a$ Galleries of Cerambycid bark borer, showing how colonies of bark beetles are destroyed by this class of borers. 
The primay galleries. These are the galleries which branch off from the main entrance or the nuptial chamber.

Secondary galleries are excavated by the parent beetles, and branch off from the main galleries. The larval mines are sometimes called secondary galleries, but this term is, I think, more properly applied to those excavated by the adults.

The egg or brood galleries are the portion of the primary or secondary galleries in which eggs are deposited, and from which the larval mines, larval or pupal chambers, are extended, or in the case of the ambrosia timber beetles, the portion of the galleries in which the broods develop.

Egg cavities. These are cavities excavated by the parent beetles in the sides of the brood gallers for the reception of eggs.

Larva and pupa chambers. These are short cavities or chämbers excavated by the larvae which extend at right angles from the brood galleries of certain timber beetles.

Larva mines. This term is applied to all mines excavated

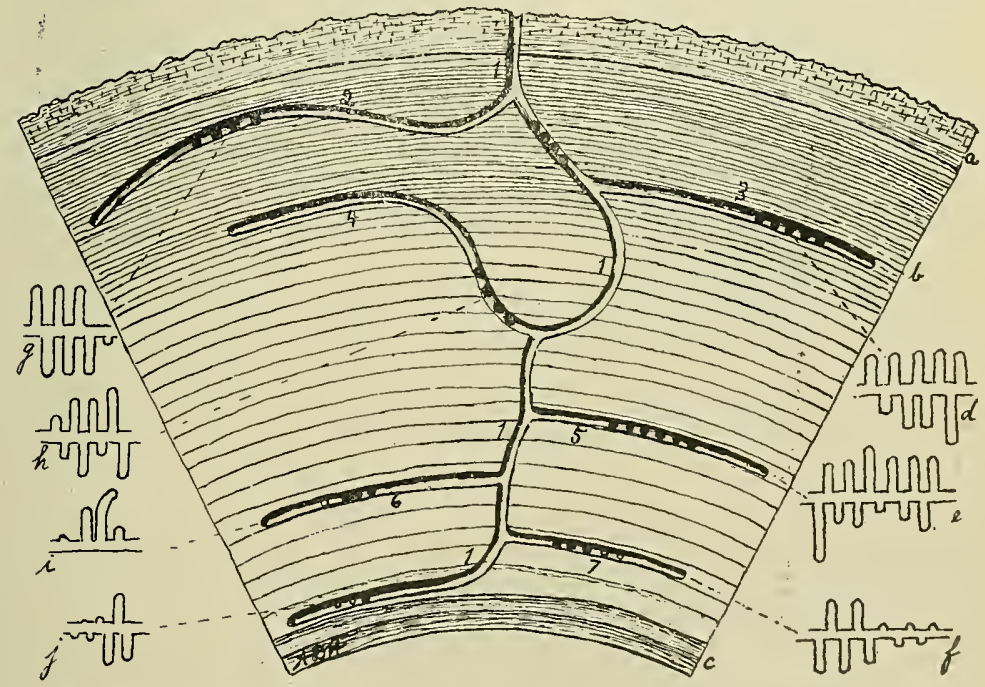

Fig. LV...-Galleries of Gnathotrichus materiarius in pine: $a$ bark, $b$ sapwood, $c$ heart wood, 1 primary gallery; $2,3,4,5,6$, and 7 secondary galleries; $d, e, f, g, h$ and $i$, brood galleries. 
in the bark or the wood"by the larvae, which extend from the egg gallery and are small at first and gradually incaease in size as the faither end or terminus is approached; thus differing from larva chambers which are of equal diameter throughout, and seldom exceed but little the length of the larva, pupa, or newly developed adult.

Pupae icases. This term refers to the cavity in the wood or bark at the terminus of the larva mines, which is excavated by'the matured larva, and in which it changes to the pupa.

Brood exits. This refers to the holes in the bark, often called "shot holes," which extend from the pupa cases to the surface and are excavated by the newly developed adults of a brood when they are ready to emerge. These exit holes in the bark differ from the main and side entrances to the galleries, in the fact that they are clear-

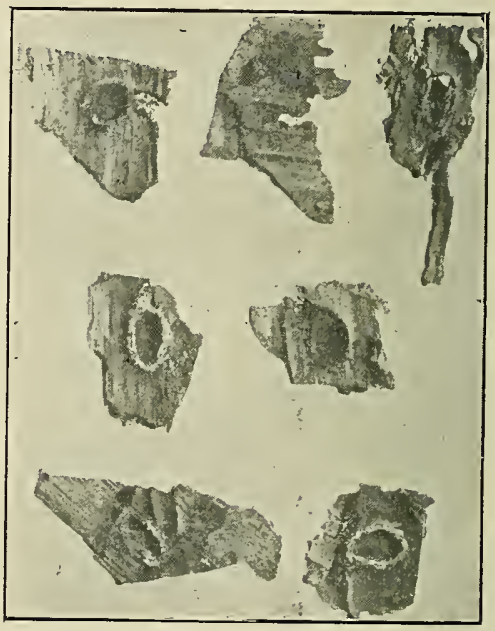

Fig. LVI. Pupa cases of Tomicus calligraphus in pine bark.

cut and are exposed or conspicuous openings; whereas those of the entrance to the galleries, are as a rule, obscured by crevices in the bark, or by elevations or projections on the surface; and also by a living or dead beetle which is often stationed at the entrance.

Hibernating burrows. These are made by the adults in the outer bark and wood of the dead and dry branches and twigs in which they pass the winter.

Food burrows. These are cavities or burrows excavated by the adults in the living bark, and at the base of small twigs, buds, or leaves, solely for the purpose of obtaining food.

Preliminary burrows or galleries. These are the same or 
similar to primary galleries except that they are excavated by the adults in a preliminary attack on a healthy, living tree apparently for the purpose of weakening its vitality, so that the conditions : will be more favorable for the development of broods from eggs deposited during a subsequent attack by other examples of the same species. These preliminary galleries are usually filled with borings and sap, or if in coniferous trees, by turpentine. If in sufficient numbers, they cause a diseased condition of the cambium and thus check the growth of wood which results in the death of the tree. If they are not in sufficient numbers to bring about this result, they heal over and do no further damage than to cause slight blemishes or defects in the wood.

\section{DISTRIBUTION OF SPECIES.}

The distribution of species in the eastern United States, and especially in West Virginia, appears to be governed largely by the distribution of the trees and plants they attack; and with possibly a few exceptions are not influenced by differences in altitude and other conditions which are known to effect the distribution

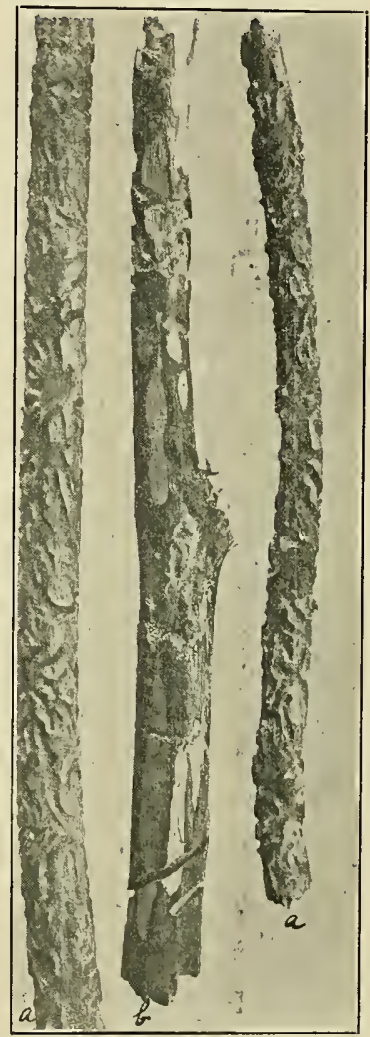
Fig. LVII-..Hibernating galpine twigs. a Gallery of Tomicus cacoyraphus, b Tomicus pini. of many forns of life in this state. Two or three spruce beetles, and one birch bark beetle appear to be confined to high altitudes, or to what is termed the Canadian Life Zone; but other spruce and pine infesting species appear to have a wide range of distribution in the State. This is a feature however, which demands further study in order to obtain anything like an accurate knowledge of the influence of the several life areas 
upon the distribution of the different species.

NATURAL ENEMIES.

The Scolytids have numerous natural enemies including iusects, diseases, birds, and unfavorable climatic and other conditions. The insect enemies may be classed under three general heads: namely, predaceous, parasitic, and robbers.

\section{PREDACEOUS ENEMIES.}

Numerous species of beetles and their young prey upon bark and timber beetles, among which the Clerids (Family (leridae) probably holds first rank; the adults feeding on the adult Scolytids, and the larvae on the eggs, larvae, pupae and recently developed adults. In the families Staphylinidae, Colydiidae, Histeridae, and Tenebrionidae, there are numerous species which enter the broad galleries of different species of Scolytids and feed upon the eggs and young larvae. I have observed a small, reddish and black bug (Hemiptera) inserting its beak beneath the elitra of a timber beelle, $G$. materiarius, which died within a few minutes after. This insect is frequently met with in the galleries of Scolytids, and it evidently destroys many of the beetles. There are also certain Dipterous larvae which attack and destroy the larrae and pupae of bark and timber beetles.

\section{PARASITIC INSECT ENEMIES.}

In this class of insects the Scolytids have a host of enemies, belonging principally to the Hymenoptera, and the families Braconidae, Chalcididae and Proctotrypidae. These are small, four winged gnats which pierce the bark with their long ovipositors or enter the galleries and deposit their eggs with, or into the larvae and pupae of the bark beetles, which are destroyed by the little maggots hatching therefrom. The adults are also attacked by this same class of four winged parasites, which develop within the body of the beetle and emerge from a hole gnawed by them through the hard elitra or wing covers. ${ }^{1}$ 
Robbers. Under this head, there are a number of large and small bark and wood boring grubs, which in extending their broad and winding mines through the bark and wood rob or deprive the Scolytids of their food supply and thus destroy enormous numbers.

Parasitic diseases. There are doubtless numerous fungus and bacterial diseases which attack the adults and young of bark beetles, but only two or three have been identified. If, as was thought probable, the destructive bark beetle was destroyed by diseases, we have in this class of enemies the most efficient destroyer of Scolytids.

Birds. Great numbers of bark beetles are destroyed by woodpeckers; but so far as 1 have observed, very little ultimate good is accomplished by them. During the great invasion of the destructiue bark beetle ( $D$. frontalis), I found that while the woodpeckers fed upon the adults, pupae and larvae of this species, they usually confined their attention to a single infested tree, among hundreds of other trees that were likewise infested, and while they would often strip the outer bark from the entire trunk and larger branches, and destroy many thousands of the insects, all that were thus destroyed would not be apparently in the proportion of more than one to many thousands that emerged from the other trees.

Unfavorable climatic and other conditions. In this class of enemies, or opposing forces, Scolytids are often destroyed in great numbers, or are prevented from breeding and increasing.

With the predaceous and parasitic insects, diseases, birds, and other enemies and unfavorable conditions all combined against the Scolytids, it would appear that the destructive species would be kept in complete subjugation. Yet, as has been frequently shown, great outbreaks and invasions occur from time to time.

Insect and other friends of scolytids. Scolytids have friends as well as enemies in insects, birds, and in man, to say nothing of many favorable climatic or other conditions which 
contribute to their welfare and help counteract the damage done to them by their enemies.

INSECT FRIENDS OF SCOLYTIDS.

The principal friends of Scolytids consists of parasites of their predaceous and parasitic enemies, which are known as secondary parasites. These are principally minute, four winged gnats belonging to the family Chaicididae. They deposit their eggs in or on the adults, larvae or pupae of the enemies of the Scolytids and destroy them in the same manner as the Scolytids are destroyed by their parasites This class of insects are among the best friends of the Scolytids in preventing the rapid increase of their enemies.

Caterpillars which defoliate trees and thus weaken their vitality, offer favorable conditions for attack by scolytids and may thus be classed among their insect friends; as may certain plant lice which attack the foliage of pine and other trees; and also certain wood-boring caterpillars and grubs which kill the twigs and branches on living trees, or cause a diseased condition of the entire tree.

Man as a friend of scolytids. Man, especially civilized man, is among the best friends of scolytids in causing favorable conditions for their multiplication. In the primitive forests of this country all but a few species of the Scolytids necessarily depend upon occasional ontbreaks of destructive species and other natural conditions for their supply of suitable material in which to breed; but upon the advent of civilized man, suitable material is furnished in the greatest abundance in the girdled trees in the settlers' clearings or in the logs, stumps, and tops of trees felled at first for building material and subsequently for commercial products. In opening up clearings and highways in and through the primitive forests of conifers the most 1avorable conditions were offered for the starting of invasions of destructive bark beetles.

FOREST FIRES.

Horest fires, directly or indirectly due to man's influence offer both favorable and unfavorable conditions for the exist- 
ence of Scolytids. Since the trees killed by fire may offer favorable conditions for their multiplication, while vast numbers are destroyed by forest fires; so that as tar as forest flres are concerned, the favorable and unfavorable conditions are about equally balanced.

BIRDS AS FRIENDS OF SCOLYTIDS.

Birds may be friendly in their relations to scolytids both in destroying their predaceous and parasitic enemies, and, as in the case of the yellow-bellied woodpecker, may be so injurious to trees as to offer favorable conditions for the attack of bark and timber beetles. The punctures in the bark made by the birds are also often utilized by bark and timber beetles for their entrance into the bark and wood; thus they are saved the labor of boring through the hard outer bark. Birds are especially useful to Scolytids in feeding upon their worst enemies-the Clerids, since both the adults and larvae of the Clerids are doubtless destroyed in great numbers by woodpeckers and other insectiverous birds. (See enemies of Clerids on another page.)

CLIMATIC AND OTHER NATURAL CONDITIONS FAVORABLE TO THE EXISTENCE OF SCOLYTIDS.

Besides the favorable conditions for the existence and multiplication of Scolytids through the influence of man, there are many natural conditions which contribute to their welfare: trees broken or felled by storms or broken by snow offer most excellent conditions for the attack and multiplication of numerous species of Scolytids, as does the small and large shrubs and trees, and the twigs and branches, which are weakened or killed by natural causes. A warm, rainy season is also supposed to be especially favorable for the breeding habits of certain Scolytids, since a certain amount of moisture in the bark and wood infested by them, is necessary for their rapid development.

\section{PREVENTIVGS AND REMEDIES.}

PREVENTIVES.

The best preventives against attack of injurious and even 
destructive Scolytid enemies of forest and fruit trees, is a vigorous and healthy condition of the kinds of trees which it is desired to protect. In the cultivated forests of Europe, and in the orchards, parks, and lawns of this country this is possible; but in the American forests, except where a thorough system of forest management is practiced, the difficulty of preventing losses from these ravages is much greater. In the case of cultivated forests this end is accomplisned by a system of thinning out the inferior, unhealthy and matured trees, in order to give the young and vigorous ones the best opportunity for healthy growth. In the indigeneous forests and farmers' wood lots an attack on healthy trees, by Scolytids which are capable of attacking and killing such trees, but prefer to infest injured or recently felled ones, may often be prevented by providing a supply of such material as will be attractive to them. ${ }^{1}$ This may be done by felling or girdling a few inferior trees, or culling out useless or objectionable trees during the winter and early spring, and leave them on the ground until the adults of the Scolytids have entered the bark and deposited their eggs, which as a rule, will be accomplished by the middle or last of May, when by removing the bark from the trunks, and burning the branches and tops, they are all destroyed.

This method is practiced at present in our forests on an enormous scale; in fact, nothing in the cultivated forests of all Europe can compare with it in its magnitude. It is not done however, with the intention of preventing the ravages of Scolytids or to destroy them, but instead, is part of the system of forest destruction practiced here. I refer to the enormous quantity of tops, $\log s$, stumps, and broken trees and branches which occur in lumbering regions. These are invaded by countless hosts of Scolytids and serve as traps in which they are destroyed by forest flires.

\section{REMEDIES.}

After a tree is once invaded by Scolytids, there is seidom any hopes of its recovery. The only method which appears to be

1 Recommended by Eichhoff and other Gcrman writers. 
worthy of recommending, is that of a Frenchman, M. Robert, 1 who found that by removing the coarse outer bark, and cutting narrow strips of bark from the trunk of infested elms, the Scolytids were either killed or driven out by the increased vigor of the tree and the greater quantity of sap which it is well known will result from this treatment. The same result I have myself found may be accomplished by simply scoring, with a penknife, the trunk and larger branches of fruit trees suffering from what is termed "bark bound." In such cases, the cut edges of the bark will rapidly separate, and a vigorous growth of the tree will follow. This method can not be practiced however, except on fruit and shade trees,

So far as an invasion by the destructive species which prefer to attack the healthy trees of a forest is concerned, there is no remedy except the possible introduction or enconragement of such enemies as will reduce their numbers or prevent an excessive increase. In fact this is all that is necessary to check the ravages of this class of insects, on healthy trees since they can only overcome the resistance exerted by the living wood and bark when the attack is made in great numbers.

A KNOWLEDGE OF THE INSECTS AND THEIR HABITS MAY PREVENT SERIOUS I,OSSES FROM THEIR RAVAGES.

A knowledge of the habits of this class of insects, the character of their work, and the conditions favorable and unfavorable for their attack and increase may prevent serious loss of timber, since by this knowledge the owner of the attacked or threatened timber may make preparations as soon as the invasion commences, to work up, and as far as possible utilize the timber as fast as it dies, or even before it is attacked. Information as to the ending of a trouble caused by them may also be of especial service to the owners of valuable tracts of timber, sunce it would prevent them from disposing of it at a sacrifice.

Thus, in mauy respects, it is of especial importance that owners of forest, shade, and fruit trees should learn as much as possible about the habits and character of this class of

1. 5th Rep't U. S. Ent. Com. p \&9; qu uoted from Miss Crmerod. 
little pests, in order that proper measures may be promptly adopted to prevent as far as possible the serious losses they are capable of causing.

DESTRUCTIVE BARK BEETLES.

Order Coleoptera; Family Scolytidae.

The Genus Dendroctonus.

The genus Dendroctonus, which is represented in America, north of Mexico by six well recognized species, ${ }^{1}$ is of especial economic interest, since it includes probably the most destructive enemies of the pine, spruce and larch, that is known The genus is also of interest on account of the remarkable habits

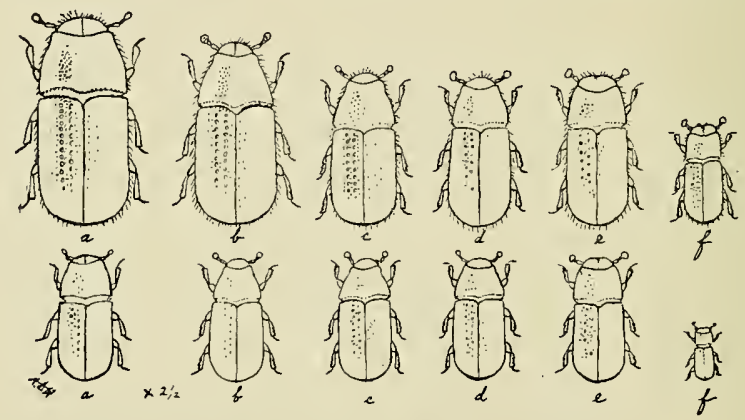

H'ig. LVIII.-Species of Dendroctonus: $a, D$, terebrans: $b, D$. ruftpennis; $c$, simplex; $d, D$. similis: e, D. approximatus;

$f, D$. frontalis.

and wide distribution of its representatives. Only four well defined species have as yet been observed in West Virginia, but the fact that some of the others may, from time to time, make their appearance here and prove destructive to our coniferous forest or shade trees, seems to warrant a brief reference to the distinctive characters, distribution, and habits of each of the common eastern species. The species vary so much in size, color and markings, and are so nearly allied to each other, that the larger ones are exceedingly difficult to correctly identify.

Dendroctonus terebrans, Oliver, Fig. LVIII, $a$. This is the

1. Sincelthis was written a large series of specimens from all parts of the country have been submitted to me for study from the National collection, and I have under taken a complete revision of the genus. to place a number of new species and varieties which will be the subject of a special paper which $I$ hope to publiș at some future time. 
largest of North American Scolytids. It varies in length from $5.2-8.5 \mathrm{~mm}$. or .20-.34 inch, color light reddish brown to black. It has been recorded from Canada and Florida in the east, and from Washington to New Mexico in the west, and is a common enemy of the pine in West Virginia, therefore, it evidently occurs throughout the United States wherever the pines grow. It attacks living and injured pines probably of all species; also the native and cultivated spruces.

Dendroctonus mufipennis, Kerby ; Fig. LVIIl, $b$. This is next in average size to the preceding species; varying in length from $6-7.5 \mathrm{~mm}$., or .25-. $30 \mathrm{inch}$; color light to dark reddish brown. It is distinguished from terebrans by its smaller average size, more slender form, narrower in front, and smoother body which is usually thickly covered with long reddish hairs. If the published records are based on correct identifications, this is a most remarkable insect in its distribution. It has been recorded from Alaska, Utah, and Colorado in the western part of North America, and from Anticosta, Pennsylvania and Florida in the East, so that it may occur throughout North America where coniferous trees are found. According to Prof. Peck, ${ }^{1}$ it is destructive to the spruce, and was associated with a trouble in the spruce forest of New York in 1879, similar to that caused by $D$. frontalis in West Virginia and adjoining states in 1890 to.'92. Dr. A. S. Packard mentions ${ }^{2}$ that he found it in its burrows under the bark of white pine at Providence, R. I., and I have identified as this species, examples received from Dr. J. A. Lintner who states that they were found in the bark of the larch at Stockbridge, Mass. ${ }^{3}$ I have one example collected in the bark of a spruce stump near Hor-

1 28th and 30th Rep't N. Y. State Museum of Natural History.

2 5th Rep't U. S. Ent. Com. p.722 under the name Polygraphus rufipennis, which was evidently meant for Dendroctonus rufipennis, since the latter species is described.

3 Since the above was written much spruce timber has been reported as dying in New Hampshire and Pennsylvania from the attack of scolytids which are supposed to be D. rufipennis, but those I have seen appear to belong to an undescribed species closely allied to it, the work of which was described in a paper by Prof. C. M. Weed and Mr. W. F. Fisk, read by the latter at the Boston meeting of the association of Economic Entomologists and published in the proceedings, Bull 17, new series, U.S. Dept. Agr. Div. Ent. pp 67-69, and is also referred to by Mr. Chittenden in Bull. 18 of the same Division, $p 96$. 
ton, Randolph county, which is closely allied if not identical to this species.

Dendroctonus simplex, Lec This species was thought by myself and Mr. Schwarz to be identical with $D$. rufipennis, but I am now convinced that it is a distinct species. It is uniformly smaller than $D$. rufipennis. It varies from 5-5. $5 \mathrm{~mm}$. or .20-.22 inches in length and from light to very dark brown. This species is also widely distributed, but is evidently restricted in its range as a destructive species to the so.called Canadian life zone.

Examples identified as this species were observed in great numbers in larch by W. H. Herrington, in Canada and by Hub. bard and Schwartz in Michigan. It was thought by Herriugton that the death of a large amount of larch was due to the primary attack of this insect. It is also recorded from Lake Superior, Colorado and California. I observed it in great numbers in the bark of standing and felled larch trees near Cranesville, Preston county, W. Va. Many large trees had died and the prevalence of the beetle and its presence in the bark indicated that they were largely to blame for the trouble. It was also found in the bark of recently felled spruce trees and logs.

Dendroctonus frontalis, Zimm. This species is easily recognized from those previously described, by its small size, dark color, and broad head and thorax. It is recorded from Lake Superior, the Virginias, Georgia, and Florida in the East, and from Colorado, Arizona, and Californin in the west. It infests and is destructive to indigenous and introduced pines and spruces.

Following will be found a more detailed description of this species and $D$. terebrans, together with an account of what I have observed with reference to their habits and life history. THE DESTRUCTIVE PINE BARK BEETLE.

\section{Dendroctonus frontalis, $\mathrm{Zimm}$.}

DESCRIPTION.

Adult: Length, 2.2-4.2mm. or .8-.17 inches ; color, light brown to black; antennae and legs, yellowish to light brown; head, with front corsely punctured and channeled in both sexes, but 


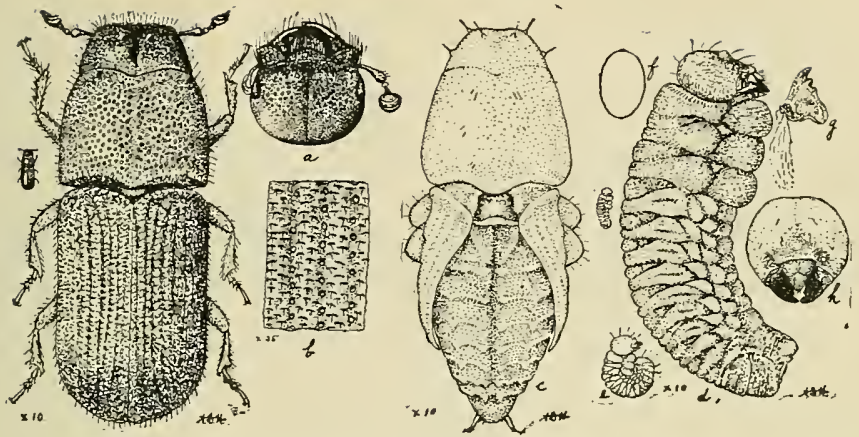

Fig. LIX--Dendroctonus frontalis*. adult. larva and pupa. $a$, front of head; $b$, elitra. enlarged: $c$, pupa: $d$. larva: $e$, young larva just out of egg; $f$ : egg; $g$, mandbile; $h$, front of head.

rougher and the frontal turburcles more acute on male than on female; while the middle front of the female is usually more convex and shining; back of head thickly covered with very fine punctures ; antennae as in illustration; club in female slightly broader and front surface more concave (dry specimens) than in male; prothorax shining, but slightly narrower in front; surface thinly covered with punctures of different sizes,

Dendroctonus frontalis, Zimm. Dendroctonus brevicornis, Lec.

\section{* BIBLIOGRAPHY.}

Zimmermann, Dr. C. Le Cont, Dr. John L.

Dietz, Dr. W. G'.

Hopkins, A. D.

Chittenden.
Trans. Amer. Ent. Soc. Sept., 1868, p. 149; original description. Ibid, p. 173, Proc. Amer. Phila's Soc. Vol., $\mathbf{X}, 1876$, p. 386, $D$. brevicornis described; further description of $D$. frontalis; correction with reference to Bostrichus frontalis, Fab. mentioned by Zimmermann which=Phloeotribus frontalis, Fab.

North American Coleoptera. [author's extra] p. 32; further description and connections with reference to D. brevicornis, Lec. which $=D$. frontalis.

In Proc. Ent. Soc., Wash.; Vol. 11, 1892, p. 353. Reference to habits.

In Science. Vol. XX, July 29, 1892 . p. 64. Reference to destructive habits.

Insect Life. Vol. VI. 1893, p 123; also 24th. An. Rep. Ent. Soc. Ontario, 1893; pp. 71-76. Account of investigation, importation of enemy, and disappearance.

Bull. 31. W. Va. Exp. Agr. Sta., 1893; p 143. No. 77. Habits. Host plants, Parasites, collecting and breeding notes.

Bull. 32. W. Va. Exp. Sta., 1893; p. 213. Host plants.

Insect Life. Vol. V. 1893; p. 187. Account of investigation.

Garden and Forest. Vol. VII, 1894; p. 348.

Canadian Entomologist. Vol. XXVI, 1894. p. 288. Sexual characters.

Southern Lumberman, 1894. Hardwood. Vol. VI. No. 5, 1894 pp. 270-271. Timberman, 1894. State and county papers. Notice of disappearance and ending of the trouble.

Canadian Entomylogist. Vol. 28, 1896; p. 24 . Reference to its disappearance and the probability of disease being the cause. Bull. No. 7 . New Series, U, S. Dep. Agric. Div. Ento., $1897 \mathrm{pp} 72$ 73. Fig. 43. Brief accouut of information from correspondence and observations by Mr. E. A. Sĉ̣warz. 
and smooth dorsal line usually distinct; elitra, with obscure rows of punctures, the interspaces roughened with irregular, transverse, shining elevations, coarser and more oblique at and near the base. In some examples the interspaces are nearly smooth; and in some the surface is clothed with long and short hairs, while in others the hairs are obscure or absent. Easily reconnized from the other species by its smaller size.

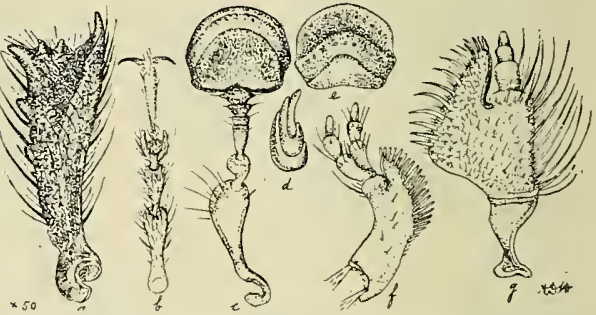

Fig. LX.-Dendroctonus,frontalis, $\alpha$, tibia: $b$, tar sus; $c$, antanna: $d$, club lateral view; $e$, club front surface; $f$, mentum; $g$, maxilla.

The egg. Fig. LIX f,-Length $7 \mathrm{~mm}$.; width, $5 \mathrm{~mm}$; pearly white and shinning.

The larva. Fig. LIX $d$. Directly after emerging from the egg, the body of the larva is much curved so that the outline forms a circle about $5 \mathrm{~mm}$ in diameter, Fig. LIX, $e$; the head is large and the mandibles stout and dark. 'The head and last abdominal segment are clothed with a few long white hairs.

The matured larva is from $5-7 \mathrm{~mm}$. long; the body nearly straight; head, large, reddish, with frontal elevation or tubercle and a few long hairs; mandibles reddish black and with obscure antennae in depressions just above the base. The body is divided into thirteen segments, the first three or thoracic segments, large, especially the ventral portion which extend beyond the tip of the mandibles; last segment truncate and clothed with a few long hairs. Described from alcohol specimens and sketched from life.

Pupa. Length, $3-4.2 \mathrm{~mm}$. Distinguished by the large head and prothorax which closely resembles that of the adult; also by the fleshy tubercles and spires on the posterior edges of the $2 \mathrm{~d}$ to $7 \mathrm{th}$ abdominal segments as viewed from above or the side; also by two long fleshy spires on the rounded ventral 
segment. Described from alcohol specimens and drawings from life. ${ }^{1}$

\section{THE GALLERIES.}

Preliminarygalleries These are usually in the form of short curved excavations made by the beetle in the living or healthy bark, which are either abandoned before completion, further excavation is checked by the death of the beetle. They are easily distinguished $1 \mathrm{rom}$ brood nalleries by the fact that
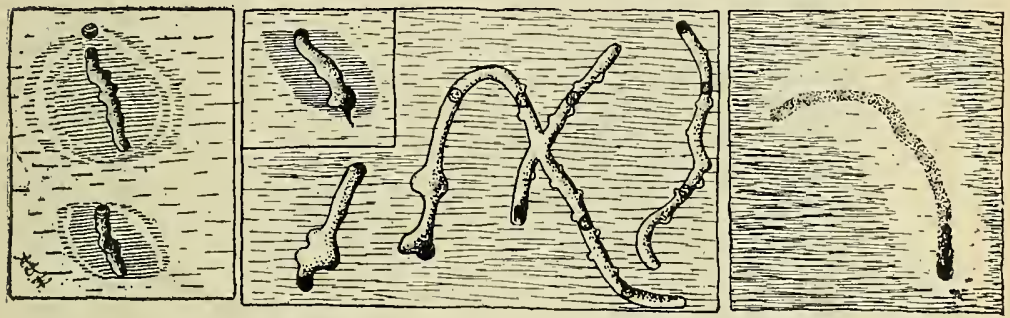

Fig. LXI.-Preliminary and brood galleries of Dendroctonus frontalis.

they are packed with borings and hardened pitch gum, attended in living and partially dead bark, by discolorations in both the bark and wood; also by the absence of egg cavities or larval mines. In dead trees, the bark and wood adjoining the preliminary galleries is the last to decay. One or more inches of the entrance end of a brood gallery when presenting this condition may be termed preliminary galleries.

The main entrance is located in the crevices or cracks in the outer bark, and if it is an entrance to a preliminary gallery takes an upward or a lateral course through the inner or living bark, often extending for some distance through the outer portion of the living bark before the inner layer is penetrated. If it is an entrance to a brood gallery, which has been excavated after the vitality of the tree had been weakened and when there was little flow of turpentipe. it extends directly through the bark to the outer layer of the wood. The entrance to the

1. The failure to take descriptive notes of the larvae and pupae when living mate rial could be had, maḳes their descriptions iṇoomplete. 


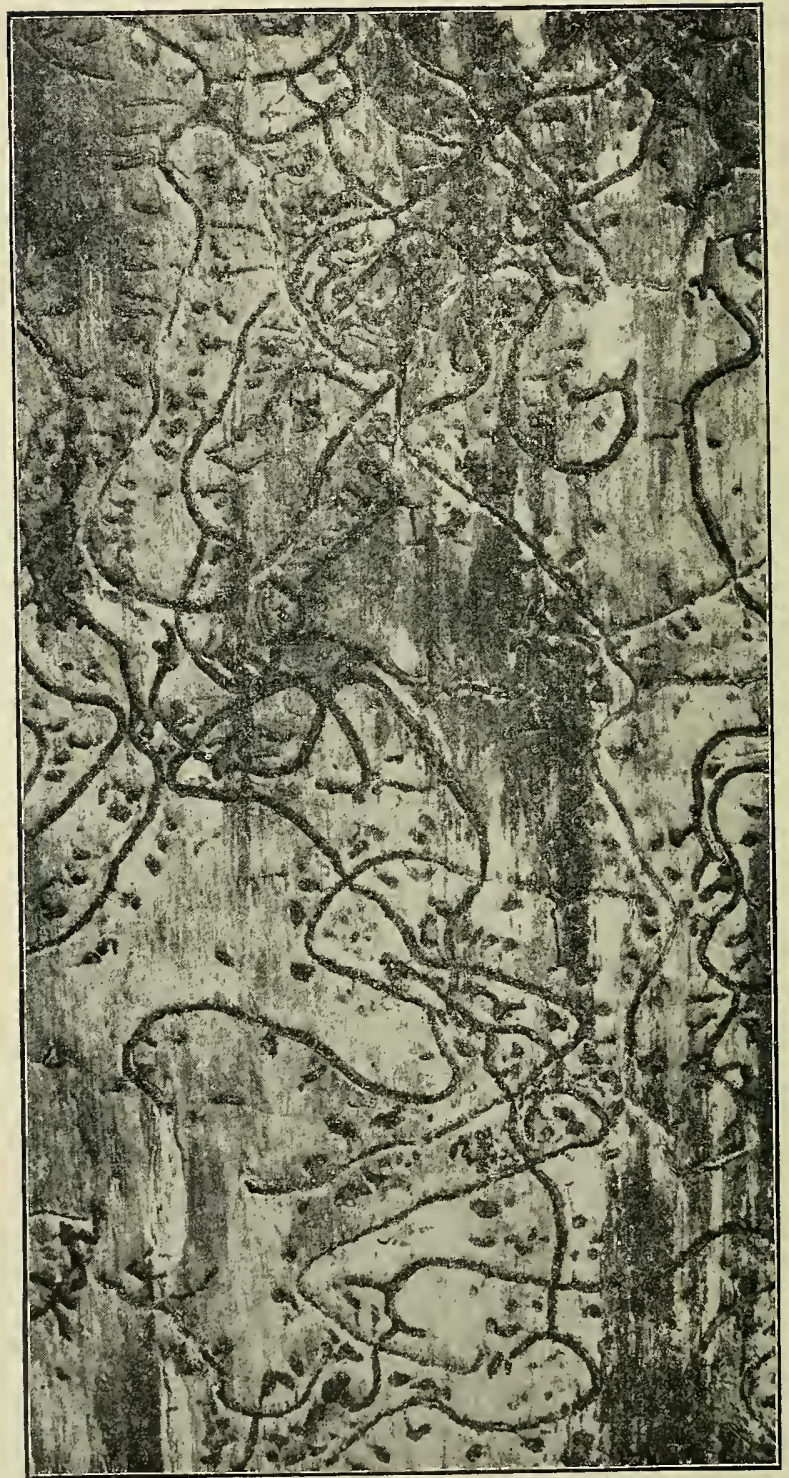

Fig. LXII.--Galleries of the destructive pine bark-beetle in pine bark 
preliminary galleries and often those of brood galleries, are marked with masses of hardened or semi-liquid turpentine through which a hole is kept open as long as this entrance is utilized by the insect, Fig. LXXII.

Side entrances or exits. These nccur at intervals along

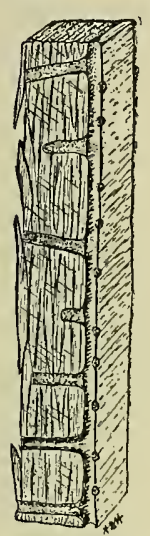

the line of the primary or brood gallery; and are usually concealed by projecting flakes of bark. When not in use, these openings are tightly packed with borings.

Nuptial chambers There appears to be nothing at the entrance end of the gallery to correspond to the so called nuptial chamber, but numerous pits occur in the roof of the gallery which may be utilized for this purpose.

Primamy, secondary and brood galleries. These are very characteristic in form and are easily recognized, although it is seldom Fig. LXIII-Gal possible to trace a finished gallery lery of Dendroe- from the beginning to the end. They showing side en-
trance and cav are long, serpentine tracks through ities.

the inner bark and crossing each other at : Imost all angles or directions, and when numerous form a confused tangle. As near as I can make ont the preliminery galleries vary from two or three inches to twelve inches in length, and may uave one or more secondary galleries branching off at irregular angles, and from one-half to four or five inches in length. Both the primary and secondary galleries are utilized for brood galleries.

Terminus of the main, or one of the secondary galleries, is usually of a peculiar form as shown in Fig. LXIV. No two are just alike but all have a general resemblance, which would indicate that they are excavated for a special purpose; either of Dendroctonus for food, or as a kind of residence for the parent

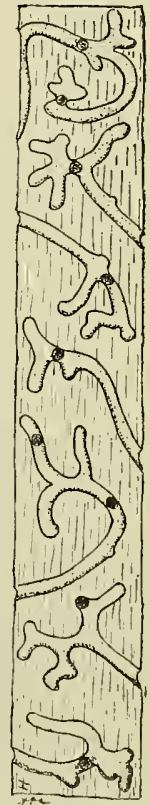

ig. LXIV--Term frontalis. 


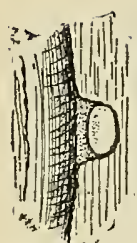

Fig.

Egg cavity and egg of Dendrocionus frontalis inside brood gallery.

beetles after their work of excavating the brood galleries has been completed.

Egg cavities, Fig. LXV, are excavated in both sides of the galleries at irregular intervals of from one-eighth to one or more inches.

Larval mines. These extend at right angles from the brood galleries, and vary greatly in size and form. The normal form is shown in Fig. LXVI. and an abnormal form in Fig. LXVIII. The fact that they extend through the outer as well as the middle

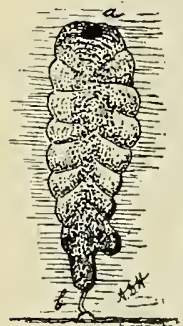

Fig. LXVII, - Nor mal larval gallery of Dendroctonus frontalis. $a$, exit of larvae; $b$, egg cavity.

served in the inner surface of the bark.

\section{Pupa cases.-}

andinnerlay-

ers of bark, prevents any thing like regularity in form as ob-

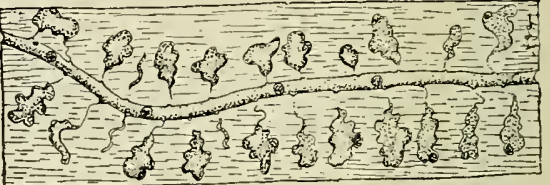

Fig. LXVI.-Gallery and larval mines of Dendroctonus frontalis, normal.

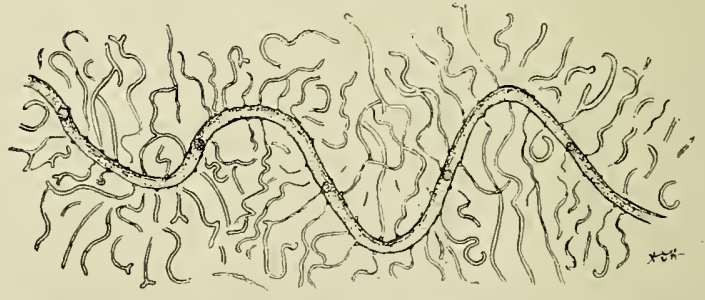

Fig. LXVIII.--Gallery of Dendroctonns frontalis, showing abnormal larval mines.

Width, 1-5 mm; length, 4-5 $\mathrm{mm}$. These are usually in the outer, corky bark, but may occur in the widened larval mines in the inner bark. The normal position however, appears to be in the outer bark as reprecented in Fig. LXIX.

Brood exits. Diameter, 1 to $1.6 \mathrm{~mm}$., occur promiscuously through the bark and in the surface exposed to view, and resemble shot holes. They extend direct from the pupa cases to the surface.

Hibernating burrows. These have Fig. LXIX--Pupa cases of not been observed but evidently occur in bark of pine.

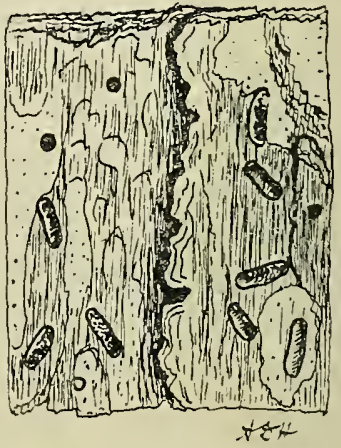


the outer bark. The largest number of adults however, pass the winter in the pupa cases.

Food burrows. The preliminary galleries, may possibly be, in some cases, excavated by the adults for the purpose of obtaining food, and the peculiar excavations at the terminus of the brood galleries may be simply food burrows. No further evidence of food burrows have been observed.

\section{LIFE HISTORY.}

The sudden disappearance of this species prevented a thorough study of its life history, but enough was learned to enable me to give a fairly complete outline of it.

Hibernation. The winter is passed in all stages, both in the inner and outer bark in which broods developed. The adults, pupae and matured larvae in the pupa cases in outer corky bark, the young larvae and eggs ${ }^{1}$ in the inner bark,

\section{ST AGES OF DEVELOPMENT.}

The egy. The exact time it takes the egg to hatch, has not been determined; but it is less than eight days and probably not more than three or four, since in breeding experiments 1 found young larvae in eight days after the female had commenced to excavate her gallery. The larva, under normal conditions, develops from the egrg to pupa in from thirty to forty days.

The pupa. The duration of the pupa stage has not been accurately determined, but the evidence obtained indicates that it is from ten to twelve days. The average duration of all stages from egg to adult I have found from breeding experiments and observations under natural conditions, to be from forty to sixty-five days, and have concluded that under normal conditions, the adult may develop and emerge in about sixty days from the time the egrg is deposited.

\section{NUMBER OF BROODS.}

The adults of the hibernating broods commence to emerge

1. Eggs were observed November 7th and the following May. The latter in galleries evidently excavated the previous fall. 


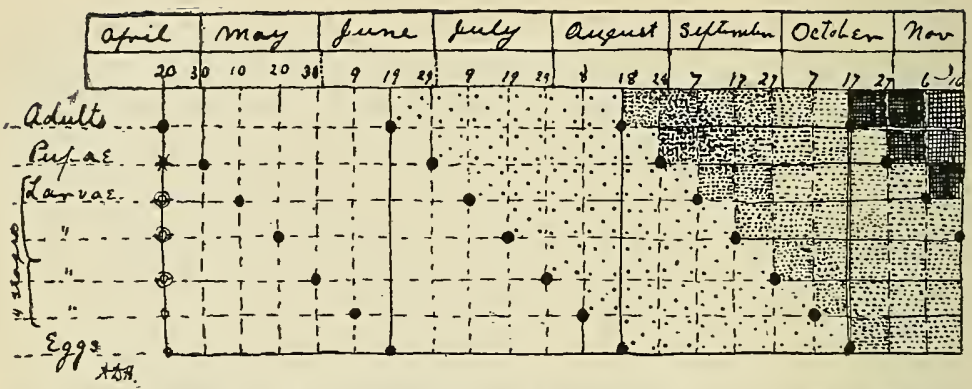

Fig. LXX--Diagram showing delopment and generations from hibernating series of Dendroctonus frontalis.

near Morgantown in April, and the first eggs are deposited about the 20th. The hibernating pupae, larvae, and eggs continue to yield adults until about the 20 th of June; by which time adults of the first series of broods commence to emerge, and continue emerging until about the 18th of August. By this time adults of the second series of broods commence to emerge and continue to come out until about the 1Sth of October, when adults of the third brood commence to appear. The adults of this series deposit eggs for the hibernating broods, eggs and nearly matured larvae of which pass the winter in the brood galleries and larval mines in the inner bark; so that there is, undor average conditions, three broods each year. ${ }^{1}$

The foregoing diagram, based upon an average of sixty days from the egg to the emerging of the adult, will illustrate the number of broods or generations from the hibernating eggs to adults, which may develope in a single season. Those developing from the first eggs deposited by the hibernating adult females are shown in line 1, from hibernating pupa and matured larrae, in lines 2 and 3 ; from nearly matured to very young larvae, in lines 4,5 and 6; and from eggs, in line 7, Thus the hibernating individuals may represent seven series, each separated by a period of ten days. The 1 st to 4 th developing three generations each between April 20th and November 16 th and the 5th to 7 th developing two generations each between

1. This has reference to the Upper Austral area in West Virginia. There is probably not over two broods in the Transition and possibly not over one in the Canadian: and under the most favorable conditions it is possible for more than three broods to develop at low altitudes aud in the southern part of the State. 
May 31st and October 31st, making a total of 48 generations from the seven different stages between $J$ une 20 th and October 18th.

\section{HABITS.}

The hibernating adults emerge from the infested trees about the middle of April, and those which emerge between that time and the middle of July, evidently do not attack the healthy, living trees, but excavate their brood galleries in the living bark of trees injured but not killed by the attack of late broods during the previous fall. By the last of July, as indicated by the diagram, a brood of adults has developed from five hibernating stages, and since each aduit probably lives a month or more, they occur at this time in great numbers; and as the flow of liquid sap is becoming less profuse under the bark at this season, they begin to attack the living trees. The first, or preliminary attack, us I have ouserved, usually fails in killing the tree if it is not followed up by successive and subsequent attacks. By the middle of August, however, all seven of the separate hibernating broods have developed into adults; and since by this time the conditions beneath the bark of living trees are most favorable for their operations, they invade the previously attacked, as well as the healthy trees, in enormous numbers, entering the bark first near the top, and later further down the trunk. The process of excavating the galleries as indicated by their form and peculiar characters is as follows :

The adults (probably both sexes) select a crevice in the outer bark of a living tree, and commence the excavation of the main entrance. The outer or dry hark, is soon penetrated and the more difficult operations of boring through the inner or living bark is continued as the conditions will permit, uutil the outer layer of wood is reached. If, as is usually the case in a preliminary attack on healthy pine trees, there is a profuse flow of sap or turpentine, the burrow is extended laterally through the outer and middle layers of the living bark for some distance (one or two inches) before the inner layer is penetrated. If there is only a moderate flow of turpentine, the 


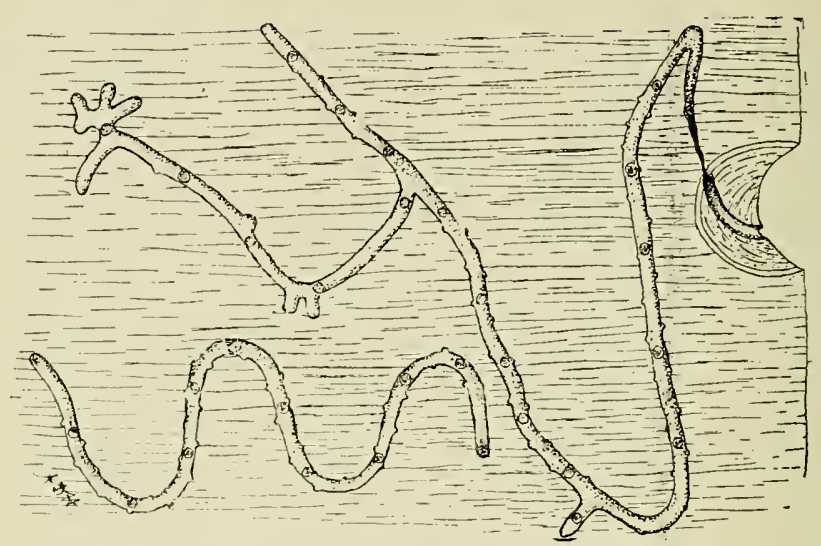

Fig. LXXI.-Completed primary and secondary galleries of Dendroctonus frontalis.

beetles bore directly through the bark to the wood and proceed to excavate the preliminary gallery through the inner bark. In this operation in healthy, living bark filled with turpentine, it is necessary for one of the beetles to continually move back and forth in the burrow, in order to keep it open and push out and dispose of the borings and inflowing turpentine, as shown in Fig. LXXII.

Thus the excavation of the entrance through the living bark is a slow and tedious process. In fact, a pair of beetles must often spend their lives under the most unfavorable conditions, affecting an entrance and the excavating of a gallery one or two inches in length. From the time they penetrate the outer layer of living bark, there must necessarily be an incessant struggle with the sticky, resinous mass which is constantly flowing into the burrow and threatening to overcome them. It is often the fate of the leaders in the attack to be imprisoned in their borrows and killed in this manner, or if not killed, may be compelled to abandon their work before the condition of the bark is favorable for them to deposite eggs. While these advance forces may fail in their object of depositing eggs and perish in the effort to overcome the resistance of the invaded trees, they make the conditions favorable for the success of 
their followers, that find, in the weakened vitality of the tree and lessened flow of turpentine, but slight obstruction to the prosecution of their work to completion.

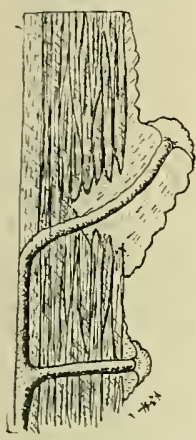

Fig. LXXII---Turpentine tube at entrance of gallery of Dendroctonus frontalis.

In the formation of the brood galleries, the same process is followed as that just described, and may often have the same character as preliminary galleries, but as the flow of turpentine ceases, the course of the gallery is changed or reversed, and is extended to completion in a more or less longitudinal direction, forming graceful curves to the right and left, so that the long fibers and cells of the inner layer of bark are severed at intervals of every one or two inches along its track, as shown in Fig. LXIl.

In the excavation of the gallery, the beetles utilize the main entrance only so $\operatorname{long}$ as it is convenient for them to eject the boring and turpentine through it, since as soon as they have proceeded one or two inches through the inner bark, they commence the excavation of a side entrance in the roof of the gallery and fill the main entrance and gallery to that point with the borings, which, being mixed with turpentine. form a hard impenetrable mass. These side entrances are excavated at intervals of one-half to one or more inches, Fig. LXIII. The first is usually filled with the borings from the second, and so on ; so that there is an opening to the surface at ali times near where the beetles are at work. Pits varying in depth, but not extending to the surface, are often excavated at intervals of one-fourth to one-half inch between the side entrances, which are evidently occupied by one sex while the other is at work excavating. These are also filled with borings when not in use for other purposes.

After the excavation of the entrance and preliminary gallery is accomplished, and about the time the first side entrance is commenced, the female commences to deposite her eggs in small cavities in each side of the gallery, at intervals of oneeight to one or more inches until the brood gallery is completed. In each of these cavities a single egg is depcsited, and se- 
curely protected by a thin wall of cemented borings between it and the main gallery, It the conditions of the bark are favorable when the larva emerges from the egg, it commences to feed, and extend a short, gradually widening mine at right angles to the brood galleries and just above, or barely through the inner layer of bark lor a distance of about one-fourth of an inch, or three to four millimetres. when it cuts. through the inner layer and gnaws out an irregular cavity two to eight millimetres wide and eight to ten millimetres, long, Fig. LXVII, in which it undergoes the greater part of its development.

When nearly matured, it bores through the outer layers of the inner bark, and as soon as it is fully developed it enters the outer corky bark and excavates an oblong pupa case, Fig. LXIX, in which it changes to the pupa, and finally to the adult. When the adult is fully developed, it bores directly out through the bark, leaving a clear cut and exposed hole in the surface. Should the conditions of the bark from any cause, be distasteful to the young larvae, or not in proper condition for its nourishment. which is often the case, it continues to bore for a long distance through the inner layer or through the inner portion of the bark, without increasing in size, as is indicated by the uniform width of the mines as show in Fig. LXVIII.

\section{HABIT OF FLIGHT.}

From such observations as I was able to make with reference to the flight of this insect,and finding examples in electric light globes, it would appear that it flies at night as well as during the day. It would also appear from the character of the attack, that at certain times during the invasion, probably from July to September, and possibiy in May, great migrating swarms occurred which ascended high in the air and were evidently carried long distances by strong winds and storms. ${ }^{1}$ This is indicated by the fact that the first groups of trees that died from its attack in a newly invaded locality, were usually on high exposed points and mountain slopes, where the swarms would

1. The wings which are exceedingiy long as compared with the size of the insect, are particularly favorable for the action of the wind in carrying them long distances. 
come in contact with the timber and commence their operations on the living trees. It also appeared from the conditions found that no choice of trees or locality was made by the swarm, but they attacked and killed those trees upon which they happened to settle in sufficient force to overcome the natural resistance met with in the living bark.

DISTRIBUTION.

The fact that this insect has been recorded from the Lake Superior region, and occurred from central Yennsylvania through Maryland, Virginia, West Virginia, District of Columbia, and North Carolina in destructive numbers, and that it has been collected in Georgia, Florida, Colorado, Arizona, and California is good evidence that it may occur at any part in the United States where the pines and spruces grow.

In West Virginia it was found by me to be exceedingly common and destructive wherever the pine grew or was common, at elevations varying from less than 500 to more than $4000 \mathrm{ft}$.

Up to the time, July, 1891, when I found it so common in Hampshire county, W. Va., it was conceded one of the rarest species of the family and was represented in but a few of the largest collections. Mr. Eichhoff, of Strasburg, Germany, had but one specimen in his great collection of Scolytids of the world, when I sent my first specimens to him for indentification, and $I$ have since found that there were but few examples in any of the collections of this country. It was exceedingly common from Pennsylvania to Florida in 1891.2, but since the spring of 1893 it has been excecdingly rare north of North Carolina. In fact, I do not know that a single living example has been observed in this region since the fall of 1892.. $\mathrm{Mr}$. Schwarz, of the Division of Entomology, at Washington, informs me that he observed it in Florida in 1894 (?) and I received it from North Carolina in $\mathbf{1 8 9 5}$, with a report that groups of pine trees were dying.

HOST PLANTS.

I have observed this insect in all af qur native species of pine 
and spruce and also in the cultivated Norway spruce, to all of which its attack proved fatal. The list is as follows:

White Pine ............. Pinus strobus L.

Scrub Pine ... ............ Pinus Virginiana Mill.

Yellow Pine .............. Pinus echinata Mill.

Table Mt. and Hickory Pine.... Pinus pungens Mich.

Pitch Pine............... Pinus rigida Mill.

Black Spruce............... Picea mariana (Mill.)B.S.P.

Red suruce(?) ...............Picea rubra, (Lamb) Link.

Norway Spruce .......... Picea excelsa, Link.

It will doubtless attack any species of native or introduced pine and spruce upon which it may happen to settle when it occurs in great swarms as it did in 1892. Hence, this insect may be considered one of the most dangerous enemies of this class of forest and shade trees.

\section{NATURAL ENEMIES.}

I have discovered a number of natural enemies of this species; but it appears that none of them are specific enemies of it, since they are all known to attack other species of bark beetles or other insects which infest the pines or spruces. Those which are parasitic on the larva or pupa are as follows:

\section{PARASITIC ENEMIES.}

Bracon pissodes Ashm-Both sexes reared from eocoons found in larval mines and pupa cases of $D$. frontalis in scrub pine near Dellslow, Monongalia county, November 7th, 1892. This, as the name inciicates, is also a parasite of a curculionid of the genus Pissodes.

Heydenia unica Cook and Davis. ${ }^{1}$-Reared from larvie found in larval mines and pupa cases of $D$. frontalis in scrub pine near Dellslow, West Virginia. This species was also reared by Professors Cook and Davis from larch infested with Polygraphus ruffpennis and Dendroctonus (similis) $=$ simplex. I have also reared it from cocoons.found in the larval mines of Pissodes strobi in scrub pine at Ronceverte, Greenbrier county, W. Va. on April 30th, I893.

1. Bull. 73. Michigan Agr. Exp. Station, 1891. p. 15, 
Doryctes sp.-Reared from pine bark infested with $D$. frontalis. Bark taken in July, 1892. This must be conceded a doubtful parasite since it was not reared direct from cocoons or larvae found in the galleries of $D$. frontalis. No other beetle was bred from the bark however.

Cecidostiba dendroctoni (n. sp.) Ashm, ${ }^{1}$ Adults collected on bark of spruce infested with $D$ frontalis, Allegheny Mountains, 4000 feet alt. June 22d, 1892, and reared from pine bark infested with $D$. frontalis. Bark taken in July, '93. This is a common parasite of the spruce bark-beetle, Polygraphus rufipennis; and has also been reared by me from pupae found in the lizrval galleries of Tomicus cacographus.

Roptrocerus ecceptogastri Ratz.-Reared from larvae associated with larvae of Heydenia unica in larval mines and pupa cases of $D$. frontalis, in scrub pine at Dellslow, W. Va., November 11th, 1892. I have also found it to be a common par. asite of Tomicus pini in white pine, Tomicus cacographus in scrub pine, and Tomicus caelatus in Norway spruce.

There are doubtless many other Hymenopterous parasites of other pine bark-beetles which would quite as readily attack $D$. frontalis.

Of the parasites mentioned, Cecidostiba dendroctoni and Roptrocerus ecceptogastri were met with most commonly, and doubtless rendered considerable service in reducing the numbers of the destructive pine bark beetle.

Thanasimus dubius Fab.-Common. Adults on surface of bark, and larvae in galleries and mines in bark of trees infested with $D$. frontalis and other pine and spruce bark-beetles. The adult feeds on the adults, and the larva on the larvae, pupae, and immature of soft adults of the bark beetles. This is the commonest enemy of all Scolytids which infest conifers.

Thanasimus (Clerus) formicarius, L.-Imported from Germany to feed upon $D$. frontalis, which it was observed to do when liberated on trees infested with this bark beetle.

1. Trigonoderus sp. Bu11, 17, W. Va, Exp. Sta. 1891, p. 102, Lochites sp. $a$ and $d$, in Bull. 31, W. Va. Exp. Sta., 1893, pp. 147-14i8; 
Hypophloeus cavus Lec.-Frequently met with in the brnod galleries of $D$. frontalis; but no observations were made as to the habits of the adult and larva.

Hypophloeus parallelus Welsh.-Found in pine bark with $D$. frontalis, and is a common species in the galleries of Scolytids in bark of coniferous and deciduous trees. It is recognized as an enemy of bark beetles.

\section{ROBBERS.}

Under this head $D$. frontalis has a few enemies, especially in the large, bark-boring grubs, the larvae of Monohammus species, and Rhagium lineatum Fig. LXXXV. The latter cuts a wide swath through the inner bark, which, if infested with Scolytids must be destroyed in great numbers both by being robbed of their food supply, and killed outright by the grubs in their operation of excavating their mines.

BIRDS.

Numerous trees were observed during the investigation which had the outer flaky bark removed by the birds from the entire trunk; giving the bark of such trees a conspicuous, reddish appearance by which they could be easily detected from a considerable distance. Dpon examination, it was found that the birds had removed the outer layer of dry bark in order to secure the larvae, pupae, and young adults of $D$. frontalis from the pupa cases, which as has been shown, Fig. LXIX, often occur in great numbers quite near the surface. It was a notable fact however, that while one tree would be completely stripped of its outer layers of bark, hundreds of other trees in the same section of the forest, or in the same group of infested trees, showed no indication of the work of birds. It appears that if a woodpecker commences on a tree in the bark of which there is an abundant supply of insects, it confines its attention to that tree alone, and that all the other woodpeckers in the same locality are attracted to it until the supply is exhausted, when they turn their attention to another tree. So that while a great number of insects are destroyed, it contributes very little towards checking the invasion. In fact, large numbers of 
parasitic and predaceous insects as well as the injurious ones, are destroyed.

Birds may render valuable service however, in the beginning of an outbreak of destructive bark beetles, especially when there are but few trees infested; since then their thorough work would reduce the number of the bark beetles sufficiently to materially check their progress, if not prevent entirely further ravages by them.

DISEASES, CLIMATIC CONDITIONS, ETC.

The subject of diseases has been fully discussed on another page, as has climatic and other unfavorable conditions.

FRIENDLY ELEMENTS WHICH FAVOR THE MULTIPLICATION OF THIS INSECT.

A succession of dry summers and warm winters with some general unjury to portions of the coniferous forests by snows and wind storms, are probably the most favorable conditions for the starting of an invasion by this destructive bark beetle. It also has friends in the parasites of its insect enemies; as, for instance the parasites of Thanasimus dubius (The American bark-beetle destroyer). This insect as I have found, is attacked by at least two parasites; one, an undetermined Ichneumonid which infests the living larvae and pupae and develops in the pupa case of its victim, in which it makes its cocoon. Another is an undetermined Tachinid somewhat less in size but resembling the common house fly, which develops in the body of the living adult. I succeeded in rearing one of these flies from a larva which emerged from the abdomen of an adult T. dubius, brit the wings did not develop sufficiently to enable it to be identified.

Birds are friends of the bark beetle so far as they feed upon their enemies, and as I have observed, wood-peckers are quite fond of the pupae, larvae, and adults of the European Clerid in its native forest, and of the American Clerids in our own forests. 


\section{REMEDIES AND PREVENTIVES.}

If as appears to be the case, this insect migrates for long distances in great swarms, there is little that can be accomplished in any single local effort to prevent its ravages or exterminate it. It is one of those problems in battling with insect foes which requires concerted action, not only by the States and Federal Government through their entomologists, but the owners of forests in all parts of the country.

If owners will report to us or some other entomologist the first appearance of groups of dying pine or spruce trees in any locality, and, if the bark of living trees is infested by insects and a piece of bark four or five or more inches square showing the character of the work in the inner bark is sent, something may be accomplished in the way of advice as to what the insect is, and if a destructive outbreak by it is threatened, if it should prove to be the work of the destructive pine bark beetle, the prompt cutting of the timber that is just commencing to die, and the removal of the bark from the trunks may prevent, at a comparatively slight expence, the loss of many thousands of dollars worth of timber and shade trees. If cutting and peeling the timber can not be accomplished it may be, under certain favorable conditions, advisable to introduce some natural enemies of the insect to aid in preventing its rapid spread.

If in the future an invasion of this insect is threatened, the prompt knowledge of it by the owners of valuable timber, may lead them to make preparations to utilize the timber as fast as it is attacked and thus prevent its loss. ${ }^{1}$

Thus, the information we are able to give in this report from investigation of the past trouble, may be utilized to good advantage in the future in preventing serious loss even if it is not possible to check the trouble.

FUTURE OUTBREAKS LIABLE TO OCCUR.

In a review of the history of similar troubles to the one describ-

1. I have been recently informed by the Superintendant of the Cumberland Lumber Company, that the total loss of their dead timber was prevented in this manner. Op. erations were pushed as rapidly as possible in the dying and dead timber, while the living was allowed to stand. 
ed in this report, which have occurred from time to time in this country and Europe during the past century, we must expect to see it repeated in the future either by this, or some other destructive bark beetle.

CHARACTERISTIC FEATURES OF INJURY TO FOREST AND SHADE TREES

BY DENDROCTONLS FRONTALIS.

The characteristic features of the work of the destructive pine bark beelle by which its presence may be detected are as follows:

First. Turpentine or gum flowing from numerous wouuds in the bark, and small globular masses of turpentine adhering to the surface on the upper portion of the trunks of living trees.

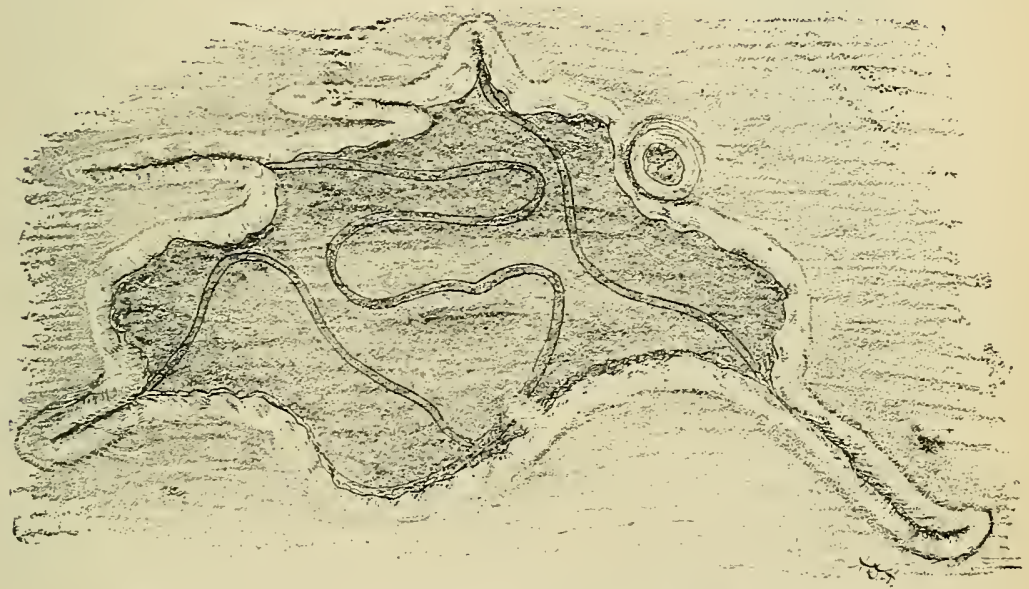

Fig. LXXII, a.-Galleries of Dendroctonus frontalis in living tree, wound healing.

Second. Groups of dying trees scattered through a pine or spruce forest; the leaves gradually changing from green to yellow, then to red and reddish brown, and remaining on the twigs for a long time after they are dead and dry.

Third. The base and lower portion of the trunk of standing trees remain alive for some weeks or months after the top is dead.

Fourth. Upon removing the bark from the upper part of the 
tree, the inner bark is found to be mined in all directions $b y$ long, winding or serpentine galleries which frequently cross and recross each other, forming such a tangle that it is seldom possible to trace a single gallery from the beginning to the end. If the bark is not entirely dead, the living adults are usually found in the main galleries, and the young grubs or larvae in the inner bark. 


\section{THE TURPENTINE BARK BEETLE.}

Dendroctonus terebrans, Oliv.

This is the "boring Hylurgus" of Harris' Treatise p. 75; but its characteristic habit of living in turpentine in the bark of pine trees has suggested turpentine bark beetle as a more appropriate common name.

It is worthy of special mention in this report from the fact that it was the speccies which was first thought to be the prime cause of the death of the pines when in July. 1891, I found it attacking healthy, living trees, also from the fact that it was one of the most common and principle allies of the destructive pine bark beetle. Another feature which appears to entitle it to second place among the insects associated with the trouble.

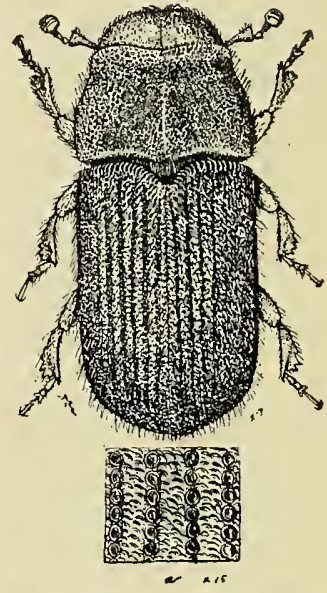

Fig. LXXIII---Dendroctonus terebrans. $a$, Elitra punctures and interspaces. is the fact that it was the only species besides the destructive pine bark beetle which was observed attacking and breeding in the bark of vigorous, living trees.

\section{DESCRIPTIONS.}

Adult. Fig. LXXIII. See description under the genus Dendroctonus, p. 392, and Fig. LXIII.

Egg, Length, .9 m.m.; width, .5 m.m.; color, white.

Larva. Fig. LXXV. Length, matured, 8-10 m.m.; width, 2.5 - 3 m.m.; described by Harris" as follows: "short, thick, nearly cylindrical body wrinkled on the back and somewhatcurved, and of a yellowish white color with horny, dark-colored head, and destitute of feet." 'To this I would add, that the large series of larvae in our collection have as the most destinctive character, a horny dorsal plate on the last abdominal segment armed with seven acute spines, four of which are curved. Fig. 
LXXV, c. It does not seem pussible that Harris would have overlooked this character, so that we either have two species which can only be distinguished in the larva stage, or Harris had the larva of some other insect before him. Probably that of Hylurgops pinifex which has somewhat similar habits and is often associated with it.

Pupa. While I have frequently observed the pupa, and reared it from larva, I failed to describe it from fresh specimens, and I believe that it has, not been described. It is of the size and form of the adult, and transforms within the brood galleries. I have never observed it in chip cocoons in the surface of the wood as mentioned by Packard. ${ }^{1}$

HABITS AND LIFE HISTORY.2

The hibernating adults commence to fly in the latitude of Morgantown, W. Va., as eariy as April 20th. It is evident therefore, that the hibernating adults

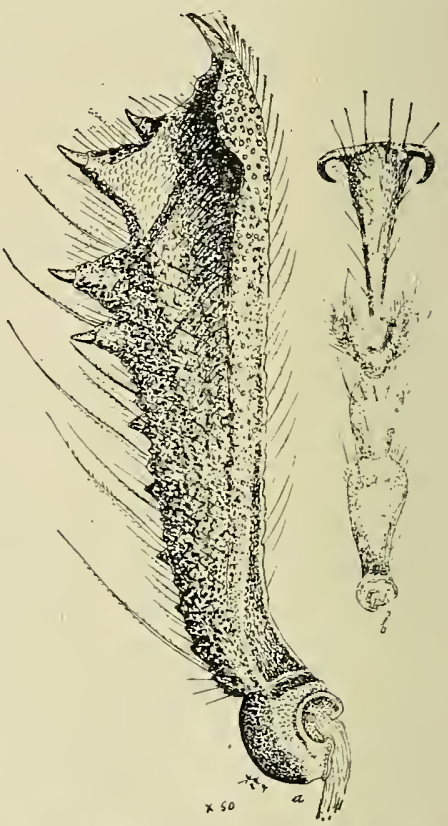

Fig. LXXIV--Dendroctonus terebrans $a$, tibia: $b$, tarsus. have all emerged by the 10th of May. The adults from hibernating pupae, and larvae appearing later.

As previously noted on page 346 , this insect sometimes occur in great migrating swarms soon after it emerges from its winter quarters. During this swarm period, and doubtless at other times, it is attracted to freshly painted buildings and to furniture shops, freshly sawed pine lumber, etc., by the odor of turpentine.

Unlike its relative, the destructive bark beetle, this species

15 th Rep. U. S. Ento. Com. p. 721., evidently refers to a curculioned larva--possibly Pissodes sp.

2 There are doubtless varieties, races, and species in other sections of the country heretofore recognized as $D$. terebrans, which will be found to have different habits from the common form referred to in this report. 
prefers to enter the bark of dying trees and that of the stumps of recently felled ones, and will attack healthy trees only

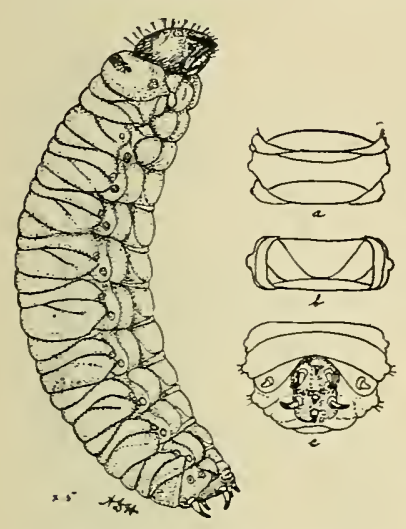

Fig. LXXV--Dendro ctonus tere. brans larva. $a$, dorsal segment: $b$, ventral segment; $c$, dorsal plate of last abdomnal segment.

when it does not find those offering more favorable conditions.

It shows a decided preference for the living bark at the base of trees and stumps, and even the exposed roots, in which to excavate its brood galleries. It rarely breeds in the bark of logs on the upper portion of the trunk of standing trees.

Harris ${ }^{1}$ says that it lays its eggs in the bark of the trunk and branches of the pitch and other pines. Among a large series of collectings and observation notes with reference to this bark beetle, in all of our native pines and in the Norway spruce, I have no record of it occurring in the bark of the upper part of a standing tree, and but one or two of its occurrence in the bark of felled trees. It has almost invarably occurred at the base of living or dying trees or stumps, and often in the roots beneath the surface of the ground.

The parent beetles select a crevice in the bark and excavate the main entrance to the inner bark through which the gallery is extended. If the bark is full of turpentine, progress is slow, and often a great quanity of this resinous substance is pushed out, frequently forming masses as large as in walnut at the mouth of the entrance.

The primary gallery is usually extended longitudinally, both above and below the main entrance, seldom in a lateral direction, although the secondary or branching galleries may do so. Twenty to forty eggs are placed in a mass along the sides of the main or secondary galleries, and when the larvae emerge

1 Insects injurious to vegetation. Flint Ed. p. 85. 
they proceed in a body to feed on the bark before them, Fig. LXXVII, and ultimately eat out a great cavity as shown in the same figure.

This social brood chamber is often extended down towards or even into the bark of the roots in such a manner as to hold the turpentine flowing into it. Thus the larvae are often completely submerged in the viscid substance, which does not appear to inlerfere with their progress.

The first egg depositing period extends through the month of May. Larvae are found in abundance from the first of June to the beginuing of winter. Pupae commence to appear early in July and may be found from time to time until winter. It appears that adults of the first brood develop about the middle of July and emerge in August or possibly late in July, since I have found young larvae by August 10th. Late in the fall all stages are tound in the bark of infested trees, and often occur at this time under the bark of

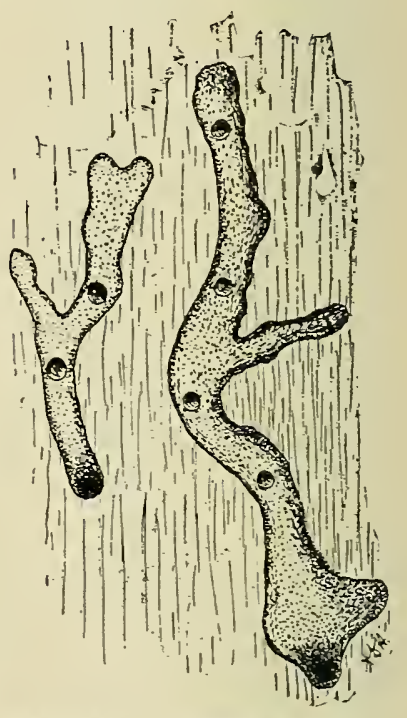

Fig. LXXVI---Primary gallery of Dendroctonus terebrans.

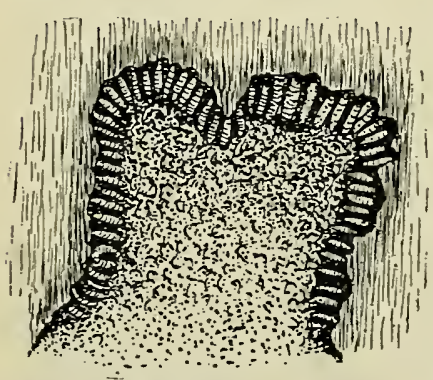

Fig. LXXVII---Larval mines of Dendroctonus terebrans.

the roots as much as six inches below the surface of the ground. The winter appears to be passed iis all stages.

Number of broods. The account of this insect by Dr. Harris ${ }^{1}$ would indicate that there is but one an. nual brood in the north, my observations lead me to conclude that there is at least two brooas in the upper Austral zone in West

1 Ins. Inj. to Veg. p. 85. 
Virginia, and probably not more than one in the Transition and Canadian zones.

\section{CHARACTER OF INJURY.}

Harris" says that "their depreditions interrupt the descent of

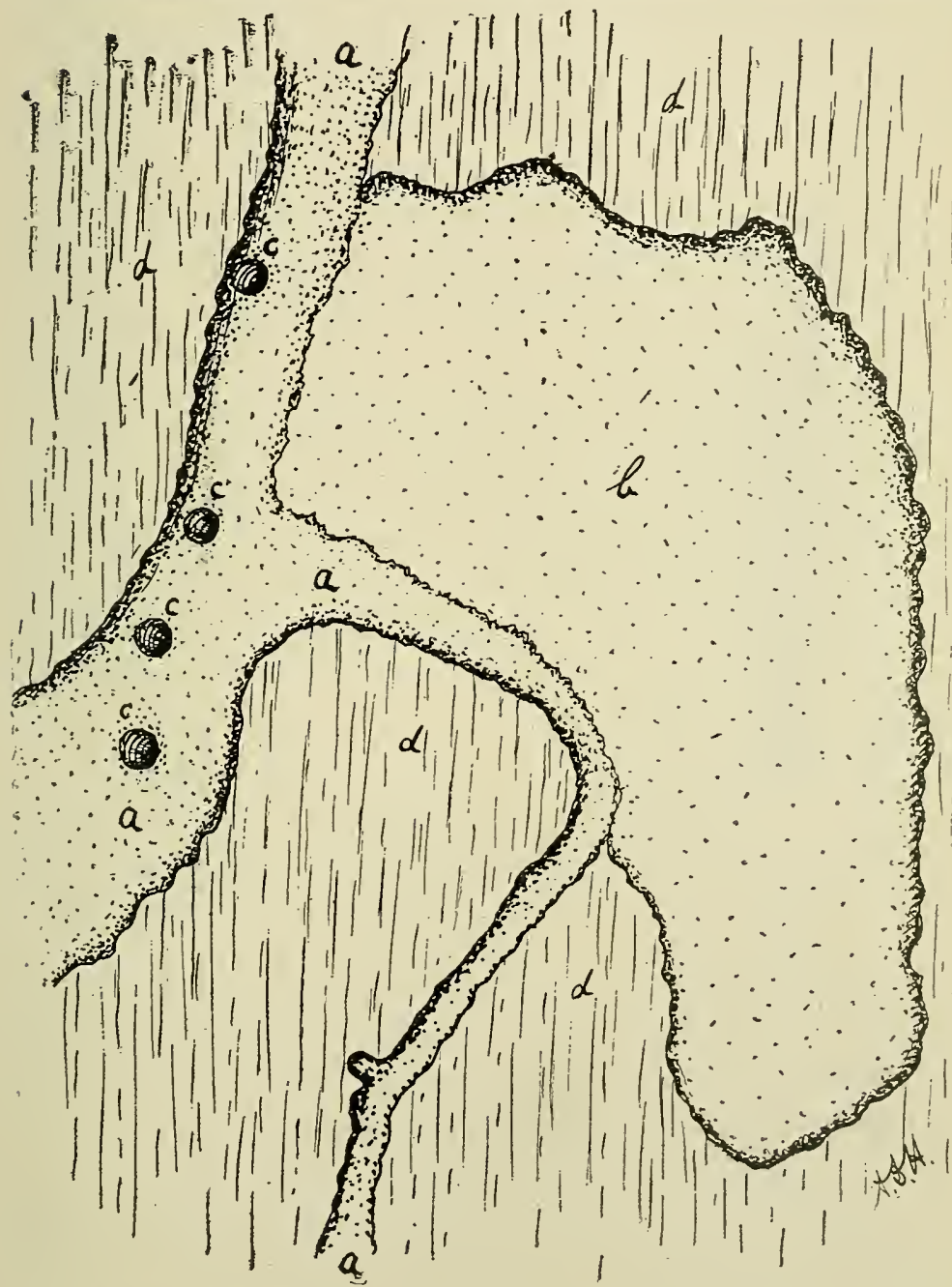

Fig. LXXVIII-.-Galleries and mine of Dendroctonus terebrans; a, primary and secondary gallery; $b$, social larval cavities; $c$, side entrances; $d$, inner bark.

1 Insects Inju rious to Vegetation, pp. 85:86, 
the sap and prevent the formation of the new wood * * and the tree languishes and prematurely decays." My observation lead me to conclude that even when our common form occurs in great numbers it is not capable of killing trees. After the great swarms of this species in May, 1893, it attacked the base of the trunk and roots of healthy pines of all kinds and some vigorous Norway spruce trees in Morgantown, and while it was capable of excarating galleries and even developing broods

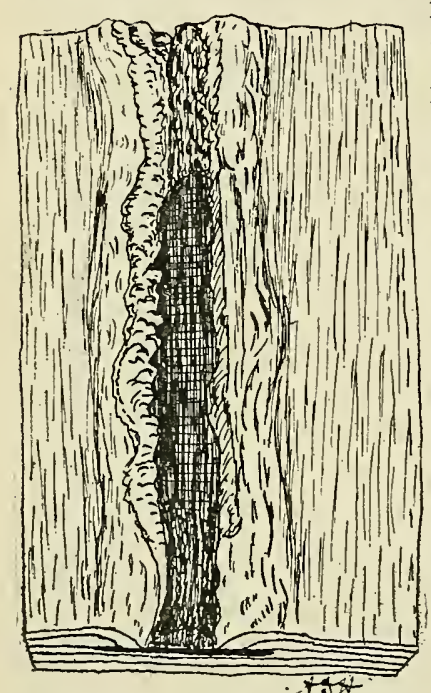

Fig.'LXXIX-.-Gallery of D. terebrans in living tree, healing over. in the bark, none of the invaded trees appeared to suffer in the least from their presence, and the wounds subsequently healed.

As a confederate of Dendroctonus frontalis and other insects which cause injuries that weaken the vitality of the trees, the turpentine beetle may assist greatly in killing them, or may alone prevent their recovery. In this manner this species may be classed as a secondary destructive enemy of conifers.

\section{KIND OF TREES ATTACKED.}

I have found it attacking all of our native species of pine, the native spruce, the cultivated spruce

and a cultivated pine.

Occurrence. It was exceedingly common during the invasion by Dendroctonus frontalis, and occurred in enormous numbers during the spring of 1893 . After that it gradually became less common and since 1895-96 has been rare.

NATURAL ENEMIES.

Insects. This bark beetle appears to have but few insect enemies. The following are all that I have noted:

Thanasimus dubius. Adults observed April 30, 1893, attacking and killing adults of Dendroctonus terebrans, and on 
Oct. 22,1893, I found a larva evidently of this clerid with larvae of the bark beetle upon which it had evidently been feeding. Elaterid larva. On October 22, 1893, I found an Elaterid larva resembling the common wire worm, in the galleries of Dendroctonus terebrans feeding on a pupa.

Diseases. On October 5th, 1893, I found a colony of adults in white pine bark, which had apparently died from a fungus disease.

Cold. In May, 1893, I found that all stages of D. terebrans which occurred in the bark a few feet above the base of the trees had been killed in a similar manner as $D$. frontalis, which was evidently due to the severe freeze of the previous January.

The fact that so many individuals of this beetle survived, while all the destructive species was destroyed, is evidently due to their normal habit of occupying the bark near the ground and even beneath the surface in the bark of the roots, while the destructive species occurs only in the bark on the upper and exposed portion of the trunk.

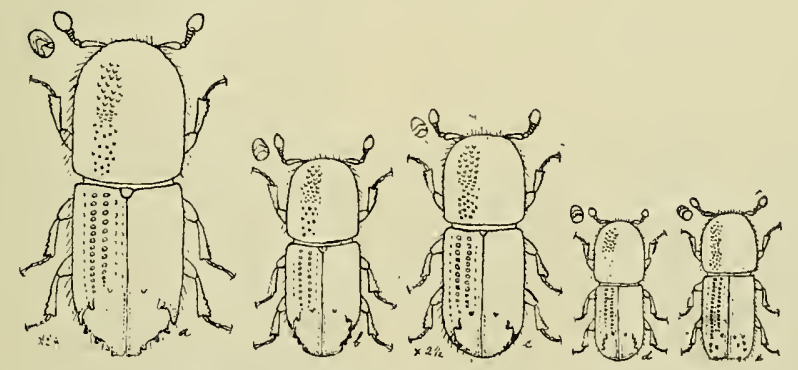

Fig. LXXX.--Species of the genus Tomicus.

THE GENUS TOMICUS.

The scolytid genus, Tomicus, which is the same as Ips of some European writers, is represented in the area covered by the invasion of the destructive pine bark beetle, by five common species out of some ten recognized species in America, north of Mexico.

They are distinguished by the peculiar concave or flattened 
elitra declivity which is armed on the sides with teeth of various sizes.

All of our species may be readily identified by the difference in size, the form of the excavation and the arrangement, number and size of the teeth.
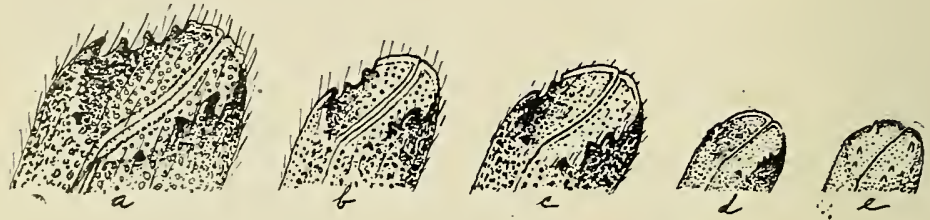

Fig. LXXXI-- Elitra declivity of species of Tomicus.

The species which are of especial interest on account of their association with the trouble caused by Dendroctonus frontalis and their power of aiding this insect in its destructive work, may be briefly described as follows:

Tomicus calligraphus Germ. Length. $4.56 .4 \mathrm{~m} \mathrm{~m}$. or .17-.25 inch.; color, reddish to black; declivity deeply excavated and armed with six teeth on each side; first from above very small, second and third large and connected at the base; fourth and fifth medium size; sixth small, as shown in Fig. LXXXI $a$.

Tomicus cacographus Lec. Length, $3-4 \mathrm{~mm}$ or .12-.16 inch.; color, yellowish red to nearly black; declivity deeply excavated and with five teeth on each side; first very small, second large and connected, fourth and fifth small.

Tomicus pini Say. 2-5.-3.5 mm. or .14-.18 inch.; color, light reddisl to dark reddish brown; declivity not so deeply excavated as.in preceding species, and with but four small teeth on each side; first very small, sometimes wanting in female; second and third medium size closely connected; fourth very small.

Tomicus avulsus Eich. Length, 2.8-3. mm or .11-.12 inch; color, yellowish to dark, reddish brown; declivity only slightly excavated and with four teeth on each side; first, very small; 
second,third and fourth small and closely connected, easily distinguished from $T$. pini by its small size.

Tomicus caelatus Eich. Length, 2.5 to $3 \mathrm{~mm}$. or .10-.12 inch; color, reddish brown to nearly black; declivity but slightly excavated and armed with three to four teeth on each side; upper ones small and irregularly arranged; the lower one larger, more acute. and situated on the flattened surface and not on the margin as with the other species.

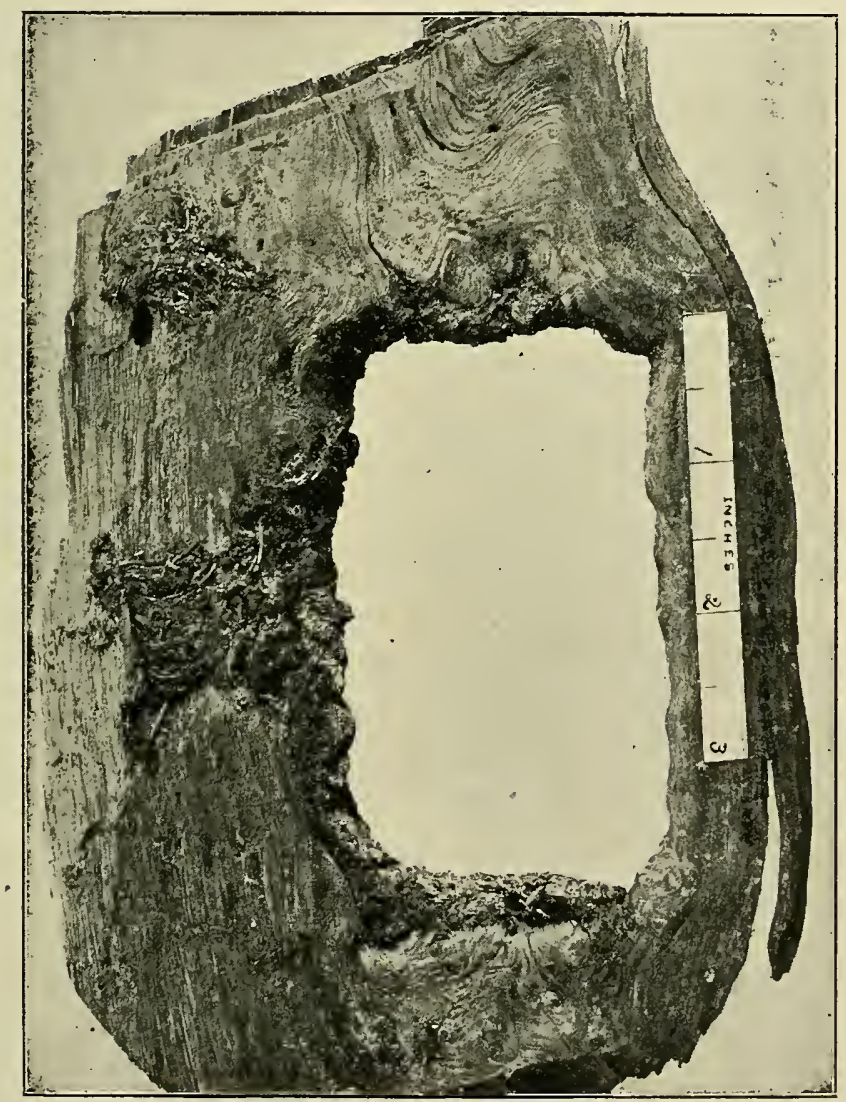

Fig. LXXXII-- Hole 4 inches long by 2 inches wide and 5 inches deep, made by wood-pecker in living tree infested with buprested larvae: fifteen annual layers of wood had formed around the entrance before the tree died. 
All of these species show a decided preference for the living bark of diseased, dying, and felled trees in which to excavate their galleries and deposit eggs. Yet they may be all classed as dangerous secondary destructive species; since they are ever ready to complete the destruction of coniferious trees commenced by other insects, or prevent the recovery of trees injured by storms, disease or other causes.

It was my intention to include in this report brief accounts of the history and habits of each of the principal pine infesting Scolytids and other insects which infest the pine and spruce of West Virginia, but since the report has about reached the limit of pages alotted to it, I will close it with an appendix giving a list of the species, with brief notes on habits and distribution, which list is intended more for the entomologist than the general reader. 
APPENDIX.

LIST OF INSECTS TAKEN FROM SPRUCE AND PINF.-1890-1898.

This list includes the names of identified insects of all kinds taken by the author from spruce and pine in West Virginia, between August 29th, 1890, and September 1st, 1898.

Many of the new Hymenoptera were named and described by Mr. Wm. H. Ashmead in The Canadian Entomologist and the Transactions of the American Entomological Society, Vol. XXI, 1894, pp. 318-344.

The Hymenoptera are arranged in alphabetical order under the family names, and the Coleoptera according to Henshaw's list, except in Scolytidae, in which some slight changes are made.

'T'he numbers following a paragraph refer to the pages of the report on which the species is mentioned.

Order hyMENOPTERA: Family LOPHyRIDAE.

1. Lophyrus pini-rigidae Hart. Larvae observed near Kanawha Station and Morgantown feeding on leaves of pitch pine; not common.

Order hyMenoptera: Family siricidae.

2. Sirex (Urocerus) cressoni Nort.=(Urocerus abdominalis Harris, in Bull. 32, W. Va. Agr. Expt. Sta.) Adult collected in wood of scrub pine at Kanawha Station, August, 1890, and flying in spruce forest at Cheat Bridge, August 30th, 1890.

3. Paururus (Orocerus)edwardsii Brulle $=($ Urocerus cyaneus Fabr, in Bull. 32, W. Va. Agr. Exp. Sta.) Several specimens taken emerging from wood of dead spruce tree; ovipositing in recently cut logs, and flying in spruce forest; Cheat Bridge, Aug. 29th, and Sept. 1st, 1890., 266.

4. Paururus (Urocerus) pinicolus, Ashm $=$ (Urocerus sp.d, in Bull. 32, W. Va., Agr. Expt. Sta.) Ovipositing in living yellow pine, Tibbs run, near Dellșlow,Oct. 21st, 1892. Remains of 
the same species found in galleries in same tree April 3d, 1897. Tree dead-evidently died in 1893 or 1894.

5. Paururus (Urocerus) cyaneus Far, = (Urocerus sp. a, in Bull. 32, W. Va. Agr. Expt. Sta,) Flying in spruce forest, Cheat Bridge, Sept. 1st, 1890.

Order HYMENOPTERA: Family CYNI PIDAE.

6. Dryophanta gemmula, Bass. Bred from pine twigs infested with Coccid and its Lepidopterous enemy Dakruma coccidivora, Com.

Order hyMENOPtera: Family ICHNEUMONIDAE.

7. Cremastus n. sp. Reared from pine twigs infested with Coccid and Dakruma cocciduvora.

8. Pimplid. Bred from larva, found in pupa case of Asemum moestum, in pine.

9. Rhyssa albomaculata Cress. Emerging from wood of dead spruce tree infested with Paururus edwardsii Bayard, July 9th, 1891; frequent, flying in spruce forest, Cheat Bridge, Sept. 1st, 1890. 266.

10. Thalessa nortoni. Oress. Ovipositing in freshly cut spruce logs in which no trace of Siricid or other larva could be found, 266.

Order hYMENOPTERA: Family BRACONIDAE.

11. Bracon mavoritus Cress. Adult on bark of dying pine tree infested with Dendroctonus frontalis and Cerambycid larva near Brushy run, Jun 23, '92.

12. Bracon pectinator Say. A common parasite of Bupestid and Cerembycid larvae in hemlock, spruce, oak and elm. Widely distributed in the State.

13. Bracon pissodes Asm. Bred from cocoons in larval mines and pupa cases of Dendroctonus frontalis in pine bark. Near Dellslow, Nov. 7th, '92.

14. Bracon simplex Cress. A common parasite of Buprest$i d$ and Cerambycid larvae in bark of spruce, oak and beech. Widely distributed. Very common in spruce forest.

15. Bracon sp.a. Larva feeding on larvae of Asemum moestum, in spruce, Bayard, July 7th, '91. 
16. Braconid, n. genus, Ashm, near Lysitermus. Bred̉ from cocoons found in pupa cases of Pityogenes plagiatus in scrub pine bark, on Mayfield Hill, near Dellslow, Oct. 14th, '92.

17. Caenophanes pityophthori Ashm. Bred from cocoons found in larvel (?) mines of Pityophthorus cariniceps in young dying spruce. Cheat Mountains, Aug. 29, '90, collected on gooseberry flowers, Kanawha Station, May 2d, '91.

18. Cosmophorus hopkinsii Ashm. Bred from spruce infested by Polygraphus rutipennis. Also taken on bark infested by same species, Cheat Bridge, Aug. 29th, '90. Later found to be a common parasite of the adult of Polygraphus rufipennis in spruce. Also bred from cocoons found in gallery of Pityophthorus n. sp. in Norway spruce, Morgantown, 1898.

Mr. Ashmead refers to this species, in a letter dated March 7th, 1893, as follows:" * * * It belongs to the genus Cosmophorus Ratzeburg, described in his 'Die Ichn'd. Forstins. Bd. II, 71, (1848) and the only specimen known is the type, C. Klugii, Ratz., figured in detail on plate 2, fig. 37. * * * Ratzeburg reared his species from Hylesinus polygraphus" (Polygraphus poylgraphus Linn).

"The genus belongs in the sub-family Euphorince and all the genera in this family are parasitic on Coleoptera, some even preying upon the perfect beetles."

19. Helcon occidentalis, Ashm. Bred from cocoon taken in pupa chamber of Tetropium cinnamopterum in black spruce. Bayard, July 8th, :91.

20. Spathius abdominalis, Ashm. Bred from cocoons found in larval mines of Dryocoetes autographus in Norway spruce. Morgantown, Mar. 15th, '91.

21. Spathius brachyurus As'm.(=Spathius brevicaudus Ashm.) Parasite of Pissodes strobi in pine; Dryocoetes autographus in spruce, bred from cocoons. Kanawha Station and Morgantown.

22. Spathius canadensis(?), Ashm. Bred from cocoons found in mines of 7 micus cacographus in white pine, Nuzums March 31, '91; also reared from cocoons found in larval mines of Copturus longulus in bark of dying scrub pine, near Berkeley Springs, Mar. 10, '97. 
23. Spathius claripennis Ashm. Collected and bred from cocoons in galleries of Polygraphus rufipennis in black spruce. Cheat Bridge and Davis, Mar. and Sept.

24. Spathius pallidus Ashm. Bred from cocoons found in larval mines of Tomicus cacographus under bark of scrub pine. Kanawha Station, June 23.

25. Spathius simillimus Ashm. Bred from cocoons found in larval mines of Chrysobothris pusilla, in spruce. Davis, Mar. $26, ' 92$.

26. Spathines tomici Ashm. Bred from cocoons found in larval mines of Dryocoetes autographus in bark of Norway spruce log. Morgantown, March 15th, '91.

27. Rhyssalus pityophthori Ashm. With Pityophthorus n. sp. in bark of dying twigs 01 yellow pine. Kanawha Station, July 29,'91.

28. Rhysipolis biformis Ashm. In mines of Cerambycid and Buprestid larvae in spruce bark. Cheat Bridge, Sept 1, Bayard, Mar. 31.

Order hymenoptera: Family chalcididae.

29. Cecidostila dendroctoni Ashm(=Triqonoderus sp., Spintherus sp., Lochites sp. c., Lochites sp. d., in Bull. 32, W. Va. Agr. Expt. Station.) A common parasite of Polygraphus rufipennis in black spruce, observed and bred in 1890, '91 and '92. Also found in spruce bark infested with Dendroctonus frontalis. Lochites sp. d (?) taken in larval mines and pupa cases of $D$. frontalis in scrub pine Nov. 7, and Oct. 10, 92. Common. Bred from pupa found in mines of Tomicus cacographus, July 15th, '93.

30. Cecidostiba polygraphi $(=\mathrm{Ashm}$. Trigonoderus sp. Spintherus sp. Bull. No. 31, W. Va. Agr. Exp. Station). A common parasite of Polygraphus rufipennis. (Wheat Bridge, Sept. 1,'90. Bayard June, '91, near Edra, Williams River, May 6, '93. Frequently bred from larvae and pupae found in larval mines of Polygrayhus rufipennis.

31. Cephalonomia hyalinipennis Ashm. Reared from spruce twigs infested with Pityophthorus n. sp. and Pityophthorus n. sp. q. taken at Cranesville, May 10th,'97. 
32. Decatomidea polygraphi Ashm.(=Decatoma sp., in Bull. No. 31, W. Va. Agr. Exp. Station). Common on spruce logs infested with Polygraphus rufipennis near Bayard, July 12th, 1891.

33. Diomorus zabriskii Cress. (?) In burrow of Hymenupterous insect in outer bark of pine.

34. Eupelmus cleri Ashm. Reared from 25 or 30 larvae infesting a larva of Thanasimus trifasciatus the latter found in pupa cases of Arhopalus fulminans Fab., in white pine bark, near Crow, April 26th, '93. Also bred from hemlock bark infested with Aulacus abdominalis and Nelanoplita fulvoguttata near Davis, Mar. 31, '91.

35. Eurytoma cleri Ashm. Bred from pupae found in larvae mines of Pissodes strobi in scrub pine, near Charleston, April 30th, '93. (The name indicates that there was some error in the note on this species, when sent to Mr. Ashmead.)

36. Eurytoma tomici Ashm. Bred from larvae found in pupae cases of Pityogenes plagiatus in pine bark. Tibbs Run, near Dellslow, Oct. 14, '92.

37. Eurytoma sp. f. Taken in larval mines of Polygraphus rufipennis, Cheat Bridge, Sept. 1, '90. (My accession number 58 in National Museum).

38. Heydenia unica C. \& D. Bred from larva taken in larval mines of Dendroctonus frontalis near Dellslow, Nov. 7, '92, from pupa found in mines of Pissodes strobi in scrub pine near Charleston, April 30, '93, aud Berkeley Springs, Mar. 10, '97.

39. Roptrocerus ecceptogastri Ratz. $(=$ Lochites sp. b \& e, Bull. 31, W. Va. Agr. Exp. Station, 1893.) Reared from larvae and pupae taken in larval mines and pupa cases of Tomicus calligraphus and T. pini in white pine bark, Moundsville, July 20th, '91; Tomicus cacographus in yellow pine, Kanawha Station, Aug. 12,'91; Tomicus caelatus in Norway spruce, Morgantown. July 13,'92; Dendroctonus frontalis in pine, Jan. '93; also reared from pine twigs taken at Dellslow, Nov. 7th, '92.

40. Roptrocerus xylophagorum Ratz.(=Lochites sp. a. Bull. 
31, W. Va. Expt. Sta., 1893.) A very common parasite of the larva and pupa of Polygraphus rufipennis throughout the spruce forests.

Mr. Ashmead refers to the two last mentioned species in a letter dated Jan. 13, 1894, as follows:

"The recognition of the two European species of Roptrocerus$R$. ecceptogastri and $R$. xylophagorum Ratzb.-is of special interest. They were originally described by Ratzeburg in Vol. I. Die Ichneu'd Forstinsectin (1844) p, 218. under the generic name Pachyceras.

"The following are the hosts of these insects after Ratzeburg. but unfortunately $I$ do not possess a late catalogue of the European Coleoptera and so can not give the names of the hosts as changed by a later nomenclature."

Parasite

Roptrocerus

xylophagorum

$$
\begin{aligned}
& \text { Bostrichus bicolor } \\
& \text { " bidens } \\
& \text { " curvidens } \\
& \text { " laricis } \\
& \text { " piceae } \\
& \text { " Pityographus } \\
& \text { " typoyraphus } \\
& \text { "villosus }
\end{aligned}
$$

Roptrocerus

ecceptogasti.

" polygraphus
Later nomenclature.

[Taphrovychus bicolor.] [Pityogenes bidens.]

[ " curvidens]

[Tomicus laricis]

[Cryphalus piceae]

[Pityophthorus pityographus.]

[Tomicus typographus]

[Dryocoetes villosus]

41. Tetrastichus thanasimi Ashm.(=Tetrastichus sp. a. Bull. 31, W. Va. Agr. Exp. Station.) Bred from larva of Thanasimus dubius in bark of black spruce taken near Davis, Mar. 29, '91, probably a secondary parasite.

42. Tomicobia tibraiis, 11.g.,n. sp. Ashm, MS. Parasite of adult Tomicus. Reared from adults of Tomicus calligraphus, taken near Berkeley Springs, Mar. 10, '97; also from adults of Fomicus pini, taken in bark of larch at Grand Forks, North Dakota, July 17, '97, and from Tomicus cacographus taken in pine bark near Dellslow, 1895 ; evidently a common parasite of Iomicus. 
43. Zapachia copturi Ashm, MS. Reared from larvae found in the larval mines of Copturus longulus Lec, in bark of small dying scrub pine near Berkeley Springs, Mar. 10, '97.

Order hymenoptera: Family Proctotrypinae.

44. Scleroderma macrogaster Ashm. Adults in mines of Xyletinus peltatus in seasoned pine board. Galleries also infested with guest bee. Kanawha Station, July 12, '94.

Order hymenoptera: Family FORMICIDAE.

45. Camponotus pennsylvanicus. Large colony working in heartwood of spruce tree about eight inches in diameter. The tree had been living when attacked and the wood had been so completely destroyed that the tree fell. Fin. LXXXIII is from a photograph of a portion of the wood taken from the stump.

Order coleoptera: Family Carabidae.

46. Cychrus ridingsii Bland. One specimen collected under bark of spruce $\log$ near Cheat, Bridge, Sept. 2d, 1890.

47. Tachys nanus Gyll. Collected under bark of spruce log, near Cheat Bridge, Sept. 1, '90.

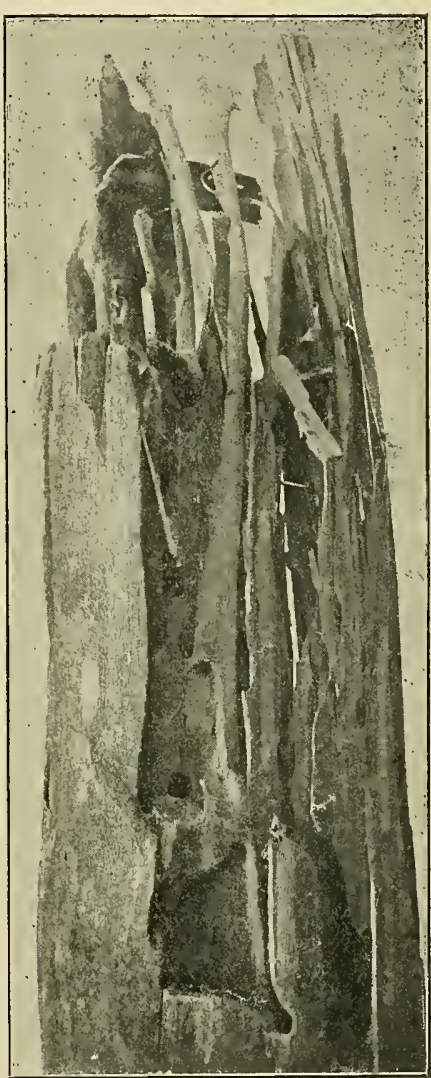

* Fig. LXXXIII-Work of black ants (Camponotus pennsylvanicus) in black spruce wood; the living tree slightly injured which gave entrance to the ants, and the heart wood was completely destroyed by them, and the tree feir.

48. Pterostichus honestus Say. Hiding under bark of decaying spruce log, near Cheat Bridge, Sept. 1, '90. 
49. Pterostichus adoxus Say. Hiding under bark of decaying spruce stump near Cheat Bridge, Sept., I, '90.

50. Platynus angustatus Dej. Hiding under dead bark of spruce stump near Cheat Bridge, Sept. 1, '90, and near Bayard July $11, ' 91$.

51. Platynus sinuatus Dej. Hiding under dead bark on spruce $\log$ near Cheat Bridge, Sept. 1, '90.

52. Dromius quadricoilis Lec. Collected under bark of spruce log near Bayard Mar. 30,'91.

53. Chlaenizes tricolor Dej. Hiding under bark of spruce log near Cheat Bridge, Sept. 1,'90.

Order coleoptera : Family scydiannidae.

54. Cholerus zimmermanni Schaum. Adults common under decaying bark of pine tree with ants; 'Tibbs Run, April 3, '97, (" *** lives under old bark of trees in company with ants." -Schwarz)

Order coleoptera: Family pselaphidae.

55. Cectius spinosus Lec. Adults under decaying pine bark with ants. Tibbs run, April 3, '97, ( “*** lives under old bark of trees in company with ants."-Schwarz.)

Order coleoptera: Famiiy staphylinidae.

56. Placusa sp. Common in brood galleries of bark beetle in pine and spruce bark, CheatBridge, Dellslow, Davis, Kanaw wha Station and Petersburg. Probably feeds on eggs of the bark beetles.

57. Quedius peregrunus Grav. Adults with Polygraphus mufipennis under bark on dead spruce tree near Cheat Bridge, Aug. 28, '90.

58. Xantholinus cephalus Say. Adults in bark of dead spruce infested with Polygraphus rutipennis, near Davis, Mar. 29 , '91.

59. Xantholinus emmesus, Grav. Reared from pupa found in galleries of Tomicus calligraphus near Evans, Oct. 6, '94. Adults common in galleries of same scolytid in pitch pine near Dellslow, Dec. 12, '96. 
60. Baptolinus longiceps Fab. Collected under bark of spruce log cut in '87, near Cheat Bridge, Aug. 30, '90.

61. Omalium pusillum Grav. In dead pine bark, Tibbs run, April 3. ("Very common under pine bark, but hardly insectiverous."-Schwarz.)

62. Olophrum obtectum Er. Hiding under pine bark near Kanawha Station, Oct. 17, '90.

63. Siagonium americanum Melsh. Under bark on roots of spruce stump, probably in galleries of Dryocoetes autographus.

Order coleoptera: Family phaLacridae.

64. Olibrus bicolor Gyll. Adults hiding in spruce bark near Cheat Bridge, Aug. 29, '90. Also collected near Kanawha Station, May 21, '90, and Glenville, July 9, '90.

Order COLEOPTERA: Family COCCINELLIDAe.

65. Chilocorus bivulnerus Muls. Feeding on Lecanium sp. on scrub pine near Romney, May 7th, '94.

Order COLFOPTERA: Family endomychidae.

66. Phymaphora pulchella Newn. Adults on spruce stump, Cranesville, June 23, '97.

67. Endomychus biguttatus Say. Under pine bark near Nuzums, Oct. 15th. '91.

Order coleoptera: Family colydidae.

68. Coxelus guttulatus, Lec. Under bark of pine tree near Romney, May 6, '92.

69. Lasconotus referendarius Zimm. Adult in white pine killed by girdling, Anthony's Creek, Greenbrier county, Oct. 10, '93.

70. Aulonium tuberculatum Lec. With scolytids under yellow pine bark near Romney, July 13, '91. Also in galleries of Tomicus cacographus in living bark of scrub pine, Charleston, April 28, '93,

71. Colydium lineola Say. With scolytids under bark of dead yellow pine tree, near Romney July 13, '91.

72. Philothermus glabriculus Lec. Found with scolytids under spruce bark near Cheat bridge, August 29, '90. 
Order cleoptera: Family cucujidae.

73. Laemophlaeus testaceus Fab. With Tomicus cacographus under pine bark, Tibbs Run, April 4, '97.

74. Dendrophagus glaber Lec. Under bark of spruce log cut in 1887, near Cheat Bridge, August 30, '90.

\section{Order coleoptera: Family histeridae.}

75. Hister lecontei Mars. Adult collected in galleries of Tomicus calligraphus in dead yellow pine tree, Jackson, Oct., 6, '94. Also in galleries of Dendractonus simplex, under bark of larch stump near Cranesville, May 9, '97.

76. Hister parallelus Say. With Dryocoetes autographus in Norway spruce bark, Morgantown, Nov., '90, with Gnathotrichus materiarius in scrub pine wood, Kanawha Station, May 18th, '90, with Tomicus cacographus in pine bark, Kanawha Station, June 24, '91; Moundsville, July 20, '91 and in galleries of Xyloterus lineatus in wood of spruce log near Bayard, May 25,'93.

77. Hister cylindricus Payk. A common predaceous enemy of Tomicus cacographus and Tomicus calligraphus in white, scrub and pitch pine, near Kanawha Station, May 8, and Aug. 12, '91; near Petersburg, May 5,'92; Piney creek, Raleigh county, Apr. 26, '93; Charleston, Apr. 28, '93; near Morgantown, July 15, '93 ; Apr. 24, '96, and May 6, '95. I also collected it in galleries of Tomicus cuelatus in white pine bark in the Middlesex Fells, Malden, Mass., A ug. 20, '98.

78. Paromalus bistriatus Er. Adult taken feeding on pupa of Polygraphus rufipennis in dying spruce tree near Edra, May 6th, '93; also taken with same bark beetle near Cheat Bridge, Aug. 30 , '90 and Davis July 11, '91.

79. Paromalus difficilis Horn. With Polygraphus rufipenmes and Dryoeoetes granicollis in bark of spruce logs near Cheat Bridge, Sept. 1, '90, and near Bayard July 8, '91.

80. Plegaderus transversus Say. With Tomicus cacographics in pine bark, Kanawha Station, June 24,'91, and Moundsville, July 20, '91. 
Order COLEoptera: Family Nitidulidae.

81. Colastus unicolor Say. With Pityophthorus conflnis and Tomicus calligraphus under bark of dead pine near Petersburg May 4, '92.

82. Epuraea avara Rand. Adult under dead bark of spruce logs near Bayard, July $8,: 91$.

83. Epuraea truncatella Mann. Adults with Polygraphus ruftpennis in spruce bark near Davis, Mar. 26, '90, and Bayard July 9. '91.

8t. Ips fasciatus Oliv, With Xyloterus lineatus in sapwood of recently cut spruce logs near Bayard, May 8, '92.

85. Ips confluentus Say, Common in galleries of Tomicus calligraphus in partly living bark of pitch pine, Tibbs Run, near Dellslow, Mar. 20, '97.

86. Ips vittatus Say. Frequent in galleries of Tomicus cacographus containing adults and young in partly living bark of white pine tree, Crow, Apr. 25, '93, also with same bark-beetle near Dellslow, Mar. 20. '97.

87. Rhizophagus culindricus Lec. Two adults under dead pine bark infested with Curculionid larvae and Scolytids, Tibbs Run, Apr. 3, '97, ("The largest and rarest species of the genus, known only from Georgia, North Carolina and Virgınia; an enemy of Scolytids."-Schwarz.)

88. Rhizophagus dimidiatus Mann. With Polygraphus rufipennis under spruce bark near Cheat Bridge, Sept. 1, '90, and Bayard, Mar. 26, '91.

\section{Order Culeoptera: Family lathrididae.}

99. Corticaria elongata Hum. Adults under bark on pine slabs with Tomicus calligraphus, Elizabeth, July 27, '91.

Order coleoptera: Family trogositidae,

90. Nemosoma cylindricum Lec. Adults in pine branches with Tomicus cacographus, near Kanawha Station, May 20, '92; Tomicus caelatus, Sept. 5, '92, and with bark beetles, Charleston, Apr. 28, '93. 344.

91. Trogosita virescens Fab. Adults under bark on dead and 
dying white and yellow pine trees, Moundsrille, July 20, 91 ; Romney, May 4, '91, and with Tomicus calligraphus in bark of yellow pine, Tibbs Run, near Dellslow, Apr. 3d, 93.

\section{Order COLEoptéra : Family elateridae.}

92. Melanotus communis Gyll. In decaying wood of pine stump and under bark of pine $\log$ from tree cut in '89, near Kanawha Station, June and Dec., '90.

93. Elaterid larvae. Found feeding on larvae, pupae and young adults of Dendroctonus terebrans near Dellslow.

Order coleoptera: Family buprestidae.

94. Chalcophora virginiensis Drury. Adult collected on dying scrub pine near Charleston, Apr. 12th. '93.

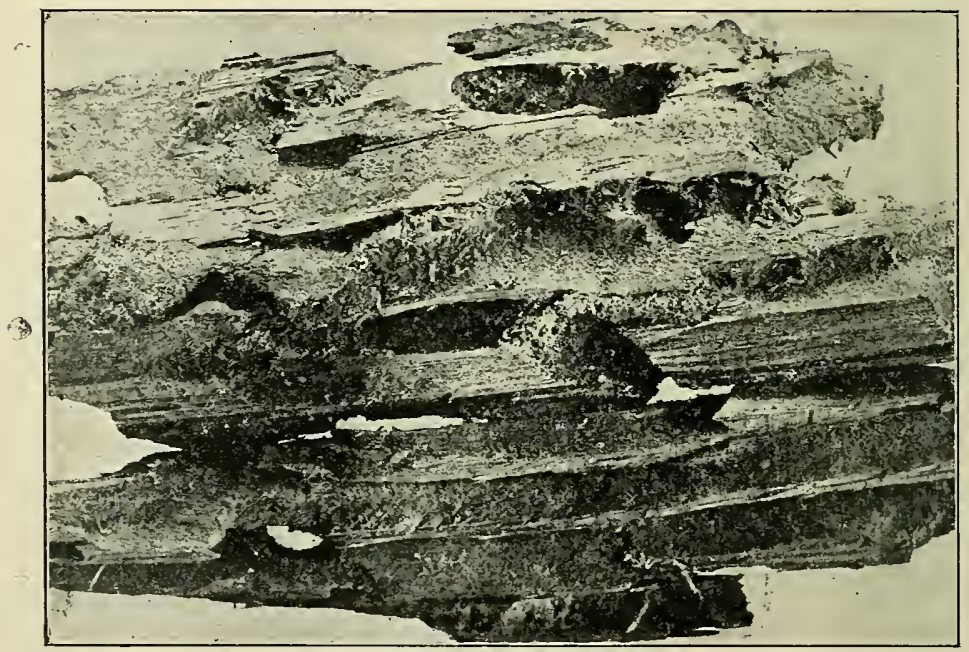

Fig. LXXXIV.-Work of large Buprestid larvae (Chalcophora liberta) in heart wood of living white pine.

95. Chalcophora liberta Germ. The destructive heartwood borer. Larvae and iragments of adults supposed to be this species found in heart-wood of living, white pine trees, doing great damage to the wood, near Crow, Dec. 1, '97.

96. Dicerca punctulata Schoenh. Dead adults in outer sapwood of small pitch pine tree that had apparently been dead 
two years, Tibbs Run, Dec. 12, '96. ("One of the rarer species of the genus, lives exclusively in conifinerous trees."-Schwarz.)

97. Chrysobothris pusilla Lap. \& Gory. Collected on spruce logs near Cheat Bridge, Sept. 1, '90, and reared from larvae found in spruce bark near Bayard, Mar. 26, '91.

98. Chrysobothris azurea, Lec. Adult taken from bark and wood of branches of dead pine trees near Kanawha S'tati,on May 15, '91, and Romney, May 3, '92.

99. Agrilus bilineatus Web. Adult collected on pine needles, Tibbs Run, near Dellslow, Oct. 6, '97. 255.

Order COLEOPtera: Family lampyridae.

100. Lucidota atra Fab. Adults under dead bark on spruce log near Davis, Mar. 29, '91.

101. Ellychnia corrusca Linn. Adults common on bark of spruce trees and logs near Davis. Mar. 29, '91.

Order coleoptera: Family cleridae.

102. Cymatodera inornata Say. Adult in outer bark of living pine, Nuzums, Oct. 15, '91.

103. Clerus quadrisignatus Say. var nigripes Say. Adults and larvae with Tomicus cacographus and Pityophthorus cribipennis in pine bark near Petersburg, May 9, '92, and Kanawha Station, Apr. 29, and May 4, '91.

104. Clerus quadriguttatus Oliv. Near dying white pine trees infested with bark beetles, Pocahontas county, May 3, '93. 345 .

105. Thanasimus trifasciatus Say. Adults and larvae with Polygraphus rufipennis under bark of spruce log near Cheat Bridge, Aug. 20, '90, Bayard, Mar. 28, '91, Williams river, near Edra, June 25th, '93. 343.

106. Thanasimus dubius Fab. A common predaceous enemy of all the bark beetles which infest the spruce and pine. Wide: ly distributed in the State. 262.

107. Phyllobaenus dislocatus Say. Adults with Polygraphus rufipennis in spruce, and larvae with Pityophthorus n. sp. l, and n. sp. q. in dead twigg of Norway spruce, Morgantown, Apr. 5th, '97. 
Order coleoptera ; Family ptinidae.

108. Xestobium squalidum Lec. Adults bred from larvae collected in dead wood of spruce, near Bayard, Mar.31, '91, and May 9, '92.

109. Xyletinus peltatus Harr. Very common in seasoned pine lumber and timber in old barn near Kanawha Station, July 13, '94.

Order coleoptera : Family scarabaeidae.

110. Valgus canaliculatus Fab. In decaying wood of pine stump, near Kanawha Station, Feb. '90.

Order coleop'tera : Family cerambycidae.

111. Prionus laticollis Drury. Reared from pupa taken in yellow pine stump near Kanawha Station, June 20, '90.

112. Asemum moestum Hald. Larvae, pupae and adults taken from sapwood of yellow pine stump near Kanawha Station, Apr. 20, '91. All stages common in sapwood and outer heartwood of white pine trees near Greenbrier river, May 3, '93. in spruce, Bayard, July 7,'91. Common wherever the pine grows. 345 .

113. Tetropium cinnamopterum Kirby. Adults common emerg. ing from wood of spruce trees that died in the summer of '95, Horton, May 20th, '96 ; collected from spruce at Bayard, May 8, and 31, '91, Mar. 31, '9I ; near Davis Mar. 29, '91. A common and serions enemy of the sapwood of dying and dead spruce timber, often causing rapid decay of the wood.

114. Phymatodes dimidiatus Kirby. Bred from larva found under bark on spruce log, on banks of Cheat River, near Ice's Ferry, June 12, '92. Adults flying, Spruce Mt., June 23, '92, Also common flying in spruce forest in Randolph county, June 21 , '92. Bred from larva found in spruce tree that died from the attack of Dendroctonus frontalis in the summer of '92, Will. iams river, May 6, '93. 346.

115. Callidium antennatum, Newn. Common in wood of dead and dying pine trees, causing rapid decay of wood. Adults and larvae near Romney, May 3, '92. 
116. Rhagium lineatum Olive. Very common bark borer in dying and dead pine trees wherever the pine grows. Adults collected May 9, Apr. 8, Oct. 7, and Dec. 19.

117. Monohammus titillator Fab. Adults on pitch pine cut in May '95, Tibbs Run, near Dellslow, May 2, '95. Collected on dying scrub pine trees in same locality, July 15, 93.

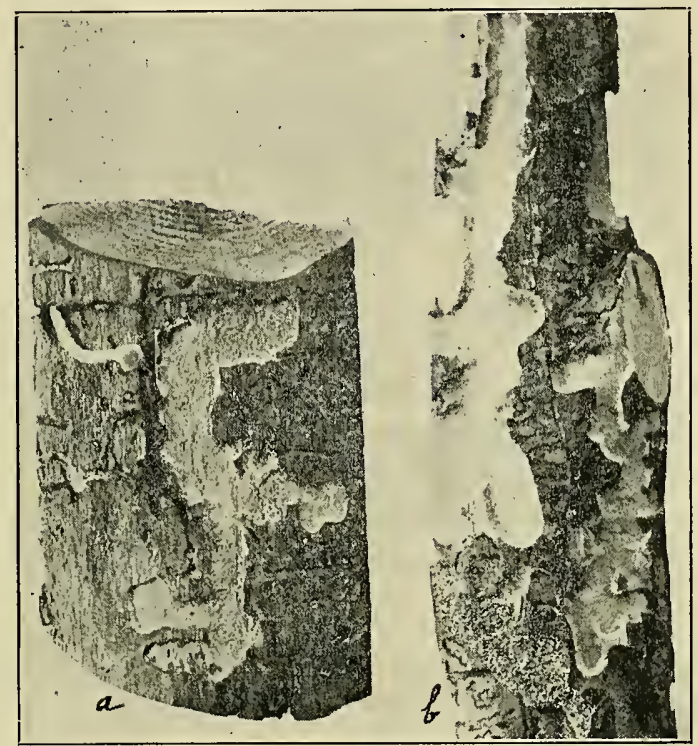

Fig. LXXXV-a, Galleries and larva of buprestid in bark of black spruce, showing destruction of colonies of Polygraphus rufipennis. b, Galleries of Callidium antennatum in outer surface of pine wood: Colonies of Scolytids destroyed by it.

118. Monohammus scutellatus Say. A common and destructive wood borer in dying and dead white pine. Brushy Run, May 5, and June 24, '92, Nuzums, Oct. 15, '91.

119. Monohammus confusor Kirby. Uommon on spruce logs in Skidway, Fig. XVIII, near Cheat bridge, Aug. 29, '90.

120. Graphisurus pusillus Kirby. Adult collected on spruce log, near Cheat Bridge, Aug 30, '90.

121. Acanthocinus obsoletus Oliv. Bred from larva in outer bark of pitch pine tree, killed by Dendroctonus frontalis, Tibbs 
Run, Nov. 7, '92. Adults emerged in breeding jar Jan., '93. Adults collected on spruce stump near Bayard, July 9, '91.

Order coleoptera: Family chrysomelidae.

122. Glyptoscleis pubescens Fab. Collected on pine leaves near Kanawha Station, June 2, '91.

Order COLEOPtera: Family tenebrionidae.

123. Tenebrio castaneus Knoch. Adult under dead bark of dying pine tree, Tibbs Run, Dec. 12, '96. ("Common under old bark of all sorts of trees."-Schwarz).

124. Hypophloeus parallelus Melsh. Very common, and an enemy of bark beetles in pine and spruce, and widely distributed. 266.

125. Hypophloeus tenuis Lec. With bark beetles in white pine bark, Anthony's Oreek, Oct. 10, '94; common in brood galleries of Tomicus calligraphus, feeding on adults; also with adult Tomicus in winter galleries in outer bark. ("Not often seen in collections; an enemy of scolytidae."-Schwarz).

126. Hypophloeus thoracicus Melsh. With Polygraphus rufipennis in bark of spruce logs, near Oheat Bridge, Aug. 29, '90.

Order colioptera : Family melandryidae.

127. Xylita laevigata Hellw. Adult in sapwood in dead spruce tree, near Davis, Mar. 30, '91.

128. Serropalpus barbatus Schall. Adult collected on spruce stump near Davis, July 10, '91.

129. Eustrophus tomentosus Say. In decaying bark of dead pine, Tibbs Run, April 3, '97. ("Common in tree fungi."Schwarz.)

130. Canifa pallipes Melsh. In pine twigs (?), June 27, 90. ("Common on old twigs of all sorts of trees."-Schwarz).

Order Coleoptera : Family pythidae.

131. Pythoniger Kirby. Adults in chip cocoons under bork of white pine logs cut the previous year: Common. Nuzum's Apl. 1, '90; adults under dead bark of spruce logs, Bayard, May 9, '92. 
132. Pytho americanus Kirby. Adults common under bark of pine tree cut the previous winter near Kanawha Station, Feb. 20, '90. Adults under bark of white pine tree killed by Dendroctonus frontalis, Orow, A pr. 26, '93.

Order colegptera : Family curculionidae.

133. Pissodes strobi Peck. The white pine weevil. Common in the terminal twigs of spruce and pine, and in bark of living, dead and dying pine and spruce trees, Cheat Bridge, Sept. 1, in spruce; Bayard. July 8 , in spruce, emerging; Spruce Mt., altitude 4860 , June 23 , '92, pupa under bark of spruce tree; Pocahontas county, June 27, in white pine; Moorefield, July 13, pupa in yellow pine; St. George, Tucker county, July 11, in Norway spruce, terminal branches of living tree; Greenbrier county, in scrub pine bark ; Kanawha Station, June 29, pupae under bark uf yellow pine: Green Springs, adults, July 14; Romney, May 3 , in scrub pine, side of living tree. 259, 345.

134. Hylobıus pales Herbst. Common in pine bark near Kanawhit Station, May, '90 and May 18, '91, near roots of dying tree; near Romney, July 14, on bark of injured pine tree; near Tibbs Run, adult at root of pine: Kanawha Station, Apr. 19, '91, flying at night.

135. Copturus longulus Lec. Reared from larvae which were comuon under bark of small scrub pine; the larvae making short mines in the inner bark and surface of wood and entering the wood to pupate; near Berkeley Springs, Mar. 10, 97. ("Widely distributed the larva is inquilinous in the galls of Podapion gallicola."--Schwarz).

Order coleoptera: Family calandridae.

136. Himatium conicum Lec. Adults common under bark on spruce logs near Cheat Brilge, Sept. 1,'90; in bark on dead spruce tree top and dead tree near Davis, Mar. 26, '91; and under bark on dying pine tree, Brushy Run, May 4, '91; flying near Kanawha Station, Apr. 17, '91.

137. Himatium errans Lec. Adult under bark of dying spruce tree, Williams River, May 6, '93.

138. Cossonus corticola Say. Adults very common under bark 
of dead pine and spruce trees, Moundsville, July 20, '91; near' Kanawha Station, June 24, July 27, and Aug. 12, '91; Romney July 13, '91, near Morguntown, July 13, '92; Nuzums Apr. 1, '91, Oct. 10, '91. Evidently feeds on dead bark.

Order Coleoptera: Family scolytidae.

139. Monarthrum fasciatum Say. Adults under bark and in sapwood of young dead yellow pine, near Kanawha Station, May, $18^{\prime}$ '91. ' Since this is the only note $I$ have of this species occurring in pine, there is a probability of an error in the original note, but I think not.)

140. Monarthum mali Fitch. With specimens received from Virginia, said to have been taken from white pine wood; taken in dead scrub pine near Kanawha Station, July 25, 91; Orow, Apr. 26, '93, in white pine. 347

141. Gnathotrichus materiarius Filch. Very common in sapwood of dead and dying pine and spruce trees, logs and stumps; widely distributed.

142. Pityophthorus pullus, Zimm(=Pityophthorus sp. g. Bull. 31, W. Va. Agr. Exp. Sta.) Common under partly living bark on dying branches and tops of pines. T'wo or three species may be included under this name, but with our present knowledge of the genus they can not be easily separated.

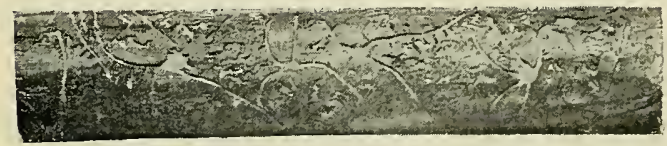

Fig. LXXXVI-Work of Pilyophthorus pulchellus in black spruce bark.

143. Pityophthorus cribripennis Eichb. Kanawha Station, Apr. 30, '91, in bark of small branches of white pine top broken by snow.

144 Pityophthorus pulchellus Eichh.(=Pityophthorus hirticeps, Bull. 31, W. Va. Agr. Exp. Station.) Adults in bark of twigs of dead young spruce near Cheat Bridge, Aug. 29, '90; Romney, May 6, '94, in bark of twigs of scrub pine; also taken at Middlesex Fells, Mass., Aug. 12, '98, in bark of pitch pine twigs.

145. Pityophthorus pulicarius Zimm. (=Pityophthorus sp. f, Bull. 31, W. Va. Agr. Exp. Sta.) Oommon in dying and dead twigs on living and felled pitch, yellow and scrub pine trees. 
146. Pityophthorus cariniceps Lec.(=Pityophthorus sp. c, Bull. 31, W. Va. Agr. Exp. Sta.) Adults in bark of dying spruce trees, Cheat Bridge, Aug. 29, '90. Also in bark and wood of terminal twigs of young dying spruce in same locality.

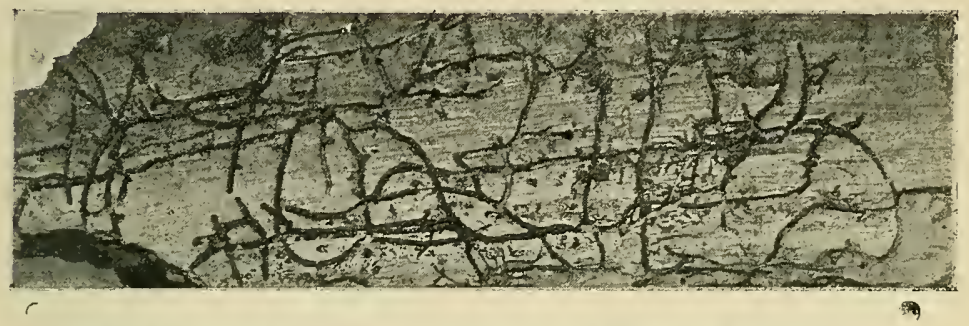

Fig. LXXXVII-Galleries of Pityophthorus confinis in bark of yellow pine.

147. Pityophthorus confinis (?). Lec. (May=P. bisulcatus Eichh.) Very common in bark of dying dead and injured pitch, scrub, yellow and white pine.

148. Pityophthorus n. sp. (=Pityophthorus lautus Eichh. Bull. 31, W. Va. Agr. Exp. Sta.) Common in dying and dead twigs of scrub, yellow and white pine.

149. Pityophthorus n. sp. e, near P. lautus. In bark and wood of dying twigs on healthy scrub pine trees; adults, pupa and larva, Kanaw ha Station, June 29, '91.

150. Pityophthorus n. sp, near Pityophthorus lautus, Eichh( $=P$. sp. e., Bull. 31, W.Va. Agr. Exp. Sta.) Adults pupae and larvae in bark and wood of dying twigs on living scrub pine tree; near Kanawha Station, June 29, '91, and Crow, Dec. 1, '97, in white pine twig, larvae half grown.

151. Pityophthorus puberulus Lec. $(=P$. sp. d. and Hypothene. mus sp. d. Bull. 31, W. Va. Agr. Exp. Sta.) Common in dying twigs of yellow, scrub and pitch pine.

152. Pityophthomes tuberculatus (?) Eichh. In bark of small dead spruce near Cheat Bridge, Aug. 29, '90.

Pityophthorus n. sp. s. Adults in dead twigs on Norway spruce; galleries in bark and, surface of wood. Morgantown, Apr. 5, '97.

153. Pityophthorus n. sp. q. Common in small dead and dy- 
ing twigs on living, dying and dead, black and Norway spruce. Eggs and matured larvae at Cranesville, May 10, and June 23, '97; adults, pupae and larvae in Norway spruce, Morgantown, Apr. 5, and Oct. 14.

154. Pityophthoms n. sp. 1. Very common in the bark of small dead twigs on dying and dead felled black and Norway spruce trees. Adults depositing eggs, Cranesville, May 10, '97; adults in Norway spruce twigs, Morgantown, Apr. 5, '97.

155. Pityophthorus n. sp. m. Adults and half grown larvae in bark of small twigs of pitch pine cut in fall of ' 96 . Tibbs Run, June 1, '97.

156. Pityophthom 11 sp.r. Adults in dead twigs of Norway spruce, Morgantown, A pr. 5, '97.

157. Hypothenemus n. sp. h. Adults common under bark and in outer wood of dead Norway sprnce twigs, Morgantown, Apl. 5, '97.

15s. Hypothenemus n. sp. i. Colony of adults in bark o1 dead Norway spruce twigs, Morgantown, Apr. 5, '97; in dead twigs of black spruce cut in 1895, Morgantown, Nov. 6, '96.

159. Xyloterus lineatus Ratz.(=Xylotems bivittatus Kirby.) Very common wherever the pine and spruce grows, attacking partly living sapwood of dying and felled trees, often causing serious injury to the wood.

160. Xyloterus scabricollis Lec. Not common. Found in partly living sapwood of dying and felled pitch, yellow and white pine trees. Romney, May 3, '92, Brushy Run, May 4, '92; Moorfield, May 3, '92, in yellow pine, near Huntersville, May 2, '93, in white pine, Tibbs Rum, Apr. 29, '96, and June 1, '97, in pitch pine. Eggs, larvae, pupae, and young adults, June 1, '97, in sapwood of stump and log of pitch pine tree cut in Angust, 1896.

161. Tyloterus politus Say. Adults in black spruce near Davis, Tucker Co., May 9, '94.

162. Cryphalus piceae Ratz. Frequently met with at high elevations in the bark of dying or dead spruce trees. Williams River, May 6, '93; Horton, May 28, '93; Cranesville, June 23, '97. Eggs, May 23, adults entering bark June 23. 
163. Xyleborus pubescens Zimm. Larvae, pupae and adults common in wood at base of dead scrub pine trees, near Dellslow, July 24, '92.

164. Dryocoetes autographus Ratz. Very common under partly living and dead bark of black and Norway spruce. More commonly met with at or near the base of stumps and dying trees, also found in pitch pine.

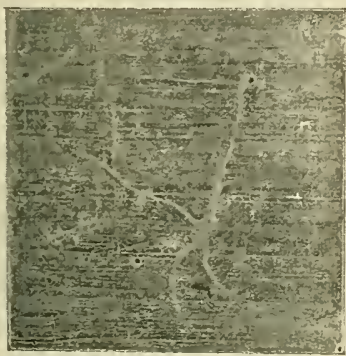

Fig. LXXXVIII-Galleries of Dryocoetes granicollis, in black spruce.

165. Dryocoetes granicollis Lec. Very common in partly living and dead bark of dying, dead and felled native and introduced spruce.

166. Tomicus calligraphus Germ. A very common bark beetle whereever the pire grows in the State, attacking partly living and dying standing and felled trees.

167. Tomicus cacographus Lec. Very common under partly living,

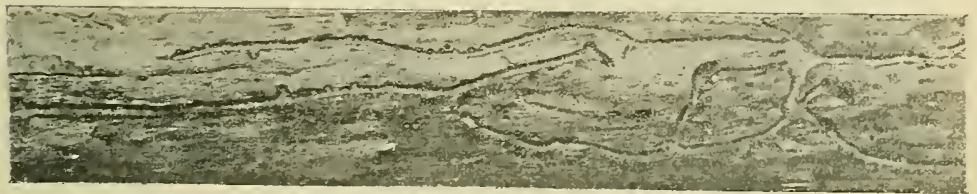

Fig. LXXXIX-Galleries of Tomicus cacographus in pitch pine.

dying ${ }_{2}^{-}$and dead bark of living, dying and dead standing and felled pine and spruce trees. Infests all of the pines and the native and introduced spruces. Widely distributed.

168. Tomicus pini Say. Very common under partly living, dying and dead bark of living, dying and clead standing and felled trees. Infests all of the pines, the larch and spruces. Especially common in white pine. Widely distributed.

169. Tomicus avulsus Eichh. Not common. Found in partly living and dead bark of scrub, pitch and white pine; Kanawlia Station, May 8, and June 23. '91, in scrub pine, near Romney, May 6, '92, in yellow pine; Brushy Run, May t,' 92 , in white pine. 
170. Tomicus caelatus Eichh. Very common in partly living bark on living, dying and dead standing and felled trees, In. fests all of the pines and the native and introduced spruces. Widely distributed.

171. Pityogenes sparsus Lec. Very common in partly living

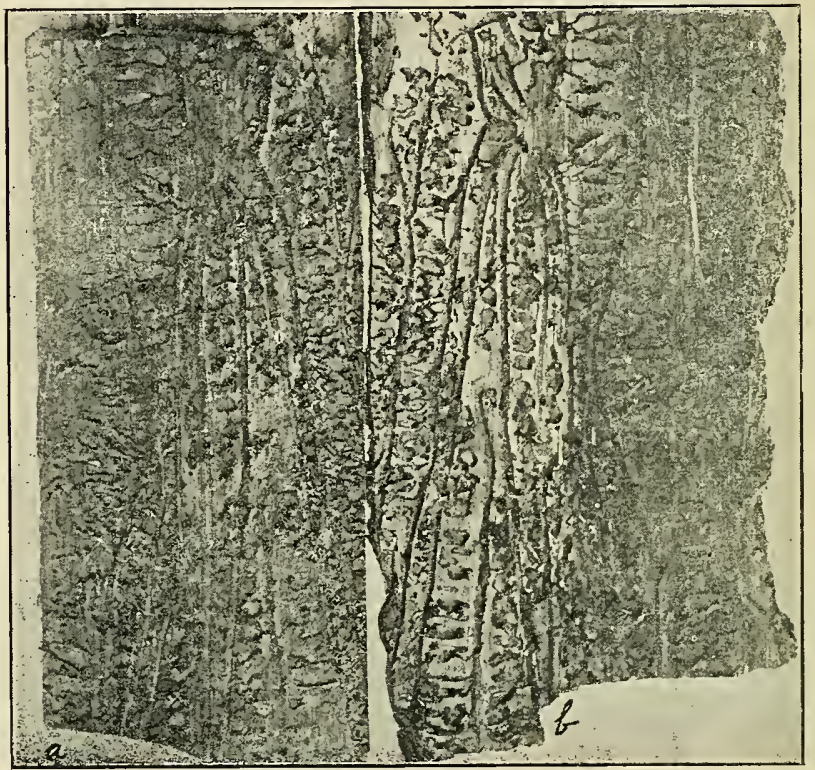

Fig. XC-Galleries of Tomicus pini in white pine; $a$, surface of wood: $b$, inner bark,

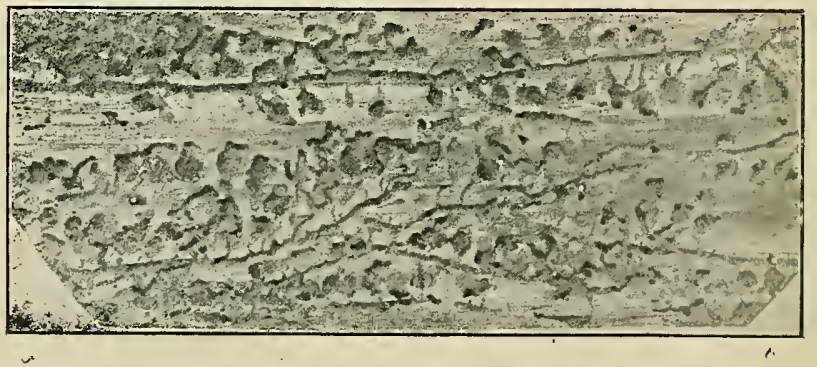

Fig. XCI-Galleries of Tomicus avulsus in bark of large scrub pine, which had recently died. 
and dead bark on branches and small twigs of standing and felled trees. Infests the white pine.

172. Pityogenes plagiatus Lec. Very common in partly living and dead bark on small injured or dying trees, and branches of large

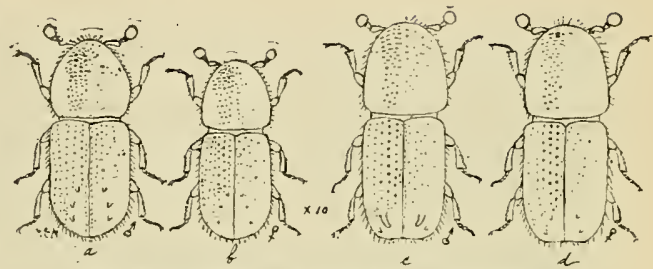

Fig. XCII-Species of the genus Pityogenes. trees. Infests the scrub and yellow pine.

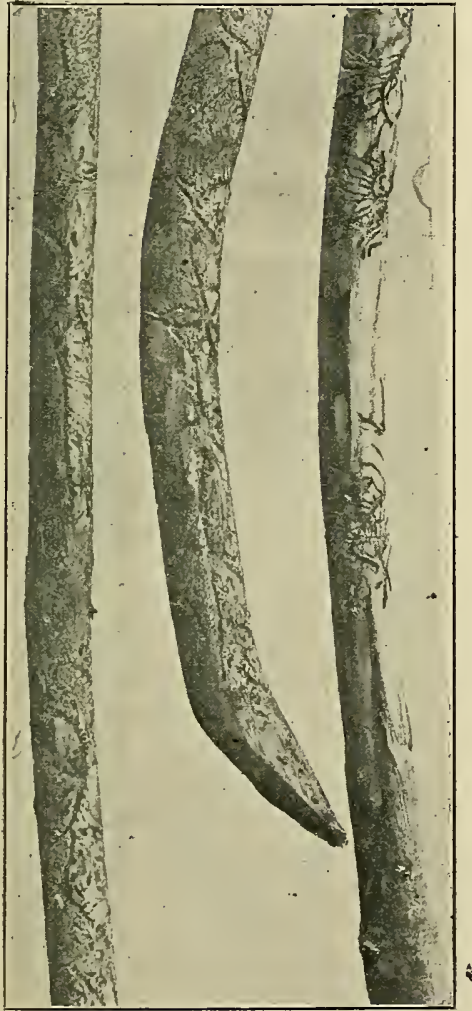

Fig. XCIII-Galleries of Pityogenes sparsus, in white pine twigs.

173. Polygraphus mufipennis Kirby. The destructive spruce bark beetle. A very common species wherever the black spruce grows in West Virginia, but only a single example has been found in pine. Appears to be confined in its distribution to the Canadian Life Zone. It has not been found in cultivated spruce in the-Upper Austral Life Zone.

174. Dendroctonus terebrans Oliv, Very common $1890,-94$, attacking all of the pines and Norway spruce near the base of living and dying trees and stumps. Widely distributed.

175. Dendroctonus sp. near Dendroctonus rufipennis Lec A single specimen found excavating gallery and depositing eggs in living bark of black spruce stump, near Horton, May 21,'93.

176. Dendroctonus simplex Lec. Adult found in bark of 
spruce log, Cranesville, May 9, '97. Abundant in bark of larch stumps and dead trees; same locality and date.

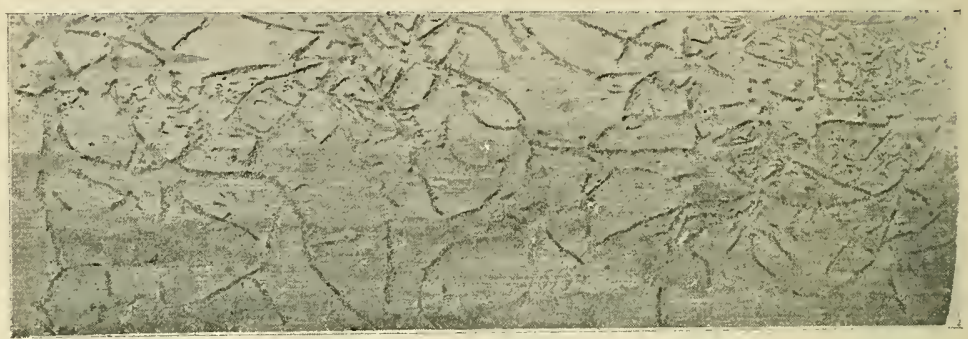

Fig. XCIV-Galleries of Pityogenes plagiatus in bark of scrub pine.

177. Dendroctonus frontalis Zimm. Exceedingly abundant in 1891 to winter of ' 92 and '93; apparently extinct in this State since the spring of 1893 . Infested living and partly dead bark of living trees. Destructive to all of the pines and the native and cultivated spruces attacked by it. Most destructive bark beetle of which we have any record.

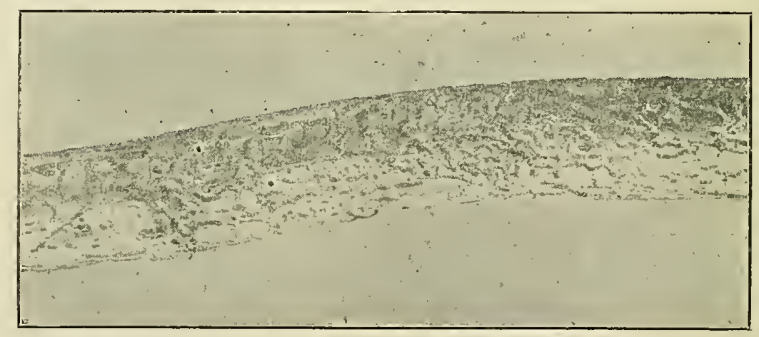

Fig. XCV--Galleries of Pityogenes plagiatus in outer surface of wood of seasoned scrub pine twig.

178. Crypturgus pusillus Gyll. Very common in dead bark of pitch, scrub, yellow table mountain pine, occupying galleries of other bark beetles, see Fig. XCVI.

179. Crypturgus alutaceus Sz. Common in dead bark of black and Norway spruce.

180. Hylastes porculus Er.(=Hylastes sp. Bull. 31. W. Va. Agr. Exp. Sta.) Rare. In bark at base of dying tree; taken in scrub, yellow and white pine, and occurring in swarm of Scoly. tids, May 4,'93. 
I81. Hylastes tenuis Zimm.(=H. gracilis Lec.) Rare. Taken in swarm, May 4, '93, and breeding in bark of pine twigs kept in basement of W. Va. Exp. Station building in '94.

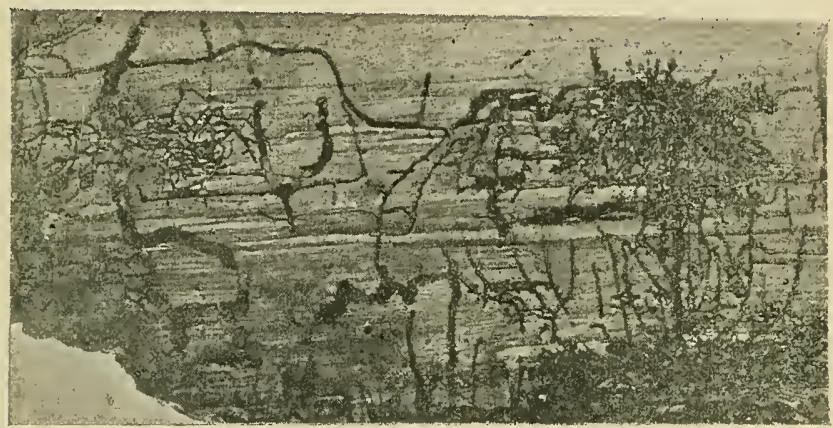

Fig. XCVI-Galleries of Crypturgus pusillus in pitch pine.

182. Hylurgops glabratus Zett.(=Hylurgops pinifex Fitch.) Very common in living, dying or dead bark at base of dying trees and stumps. Infests yellow, scrub, pitch and white pine.

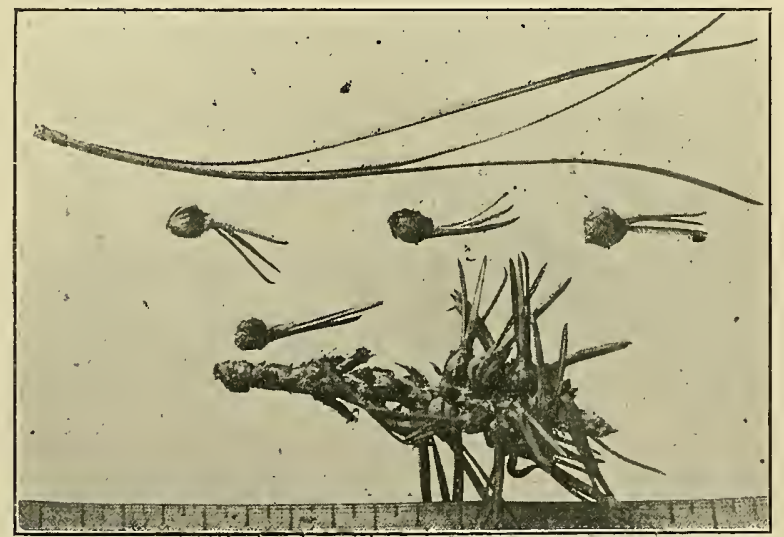

Fig. XCVII-Pitch pine needles, deformed by the pitch pine needle gall fly, also perfect needle.

Order DIPTERA: Family tachINIDAE.

183. Tachinasp. Immature adult bred from larvae which 
emerged from adult of Thanasimus dubius Aug. 12, '92; changed to pupa,'Aug. 13, '92. Adult emerged Aug. 28, '92. Beetle collected on scrub pine near Dellslow, Aug. 10, '92.

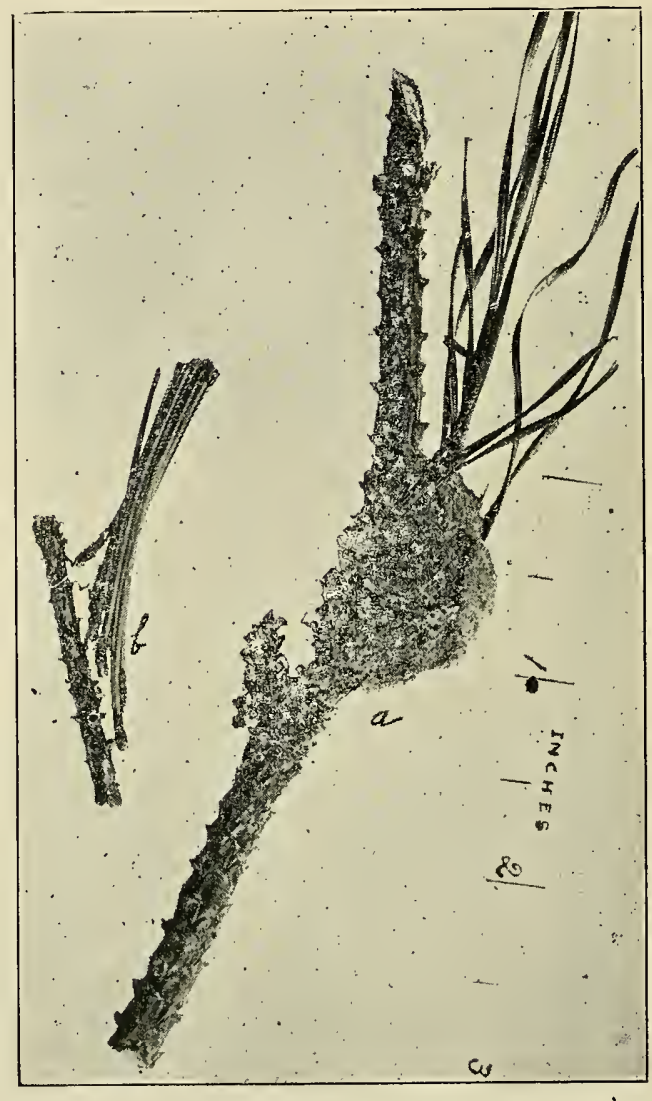

Fig. XCVIII,- $a$, Work of the pitch pine twig tortrix. $\quad b$, tube of the pine tube builder.

Order DIPTERA : Family doLICHOPOdIDAe.

184. Medeterus nigripes Loew. Common in larval mines of Polygraphus rufipennis in black spruce, near Edra, May 6, '93. Also common in mines of same species in Randolph, Tucker, and Grant?Counties. Evidently an enemy of the larva of the bark beetle. 
Order DIPTERA: Family cecidomyidDae.

185. Diplosis pini-rigidae Packard. The pitch pine needle gall fly, (See Fig. XCVII), common on pitch and yellow pine, near Kanawha Station, 1890-94; also near Morgantown.

Order lepidoptera : Family tortricidae.

186. Lophoderus politanus Haw. The pine tube builder. The work of this insect, frequently observed on yellow and pitch pine near Kanawha Station, 1890.94.

Order LePIDOPTERA : Family grapiolithidae.

187. Retinia frustrana (?) scudder. The pine moth of Nantucket. What was evidently this species had been very common along Allegheny Front, Mineral county, as indicated by the great number of dead twigs on the table mountain and pitch pines as observed July 7, '98. The characteristic mines were found, but scarcely any larvae and chrysalids; also observed near Morgantown in pitch pine. A tew larvae were found, but the adult was not ieared.

1S8. Retinia comstockiana Fernald. 'The pitch pine twig tortrix. (See Fig. XCVIII.) Common in living twigs of pitch pine near Kanawha Station; larvae June 27, '91; also in twigs of table mountain pine, May 7, '94. Frequently observed wherever pitch pine grows, forming pitch, gall-like objects on the twigs.

Order LEPIDOPTERA: Fanily GELECHIIDAE.

189. Gelechia pinifolie?la Cham. Pine leaf miner. Common in yellow and pitch pine leaves, causing tips to turn brown, Kanawha Station, May 20, '92; near Dellslow, Apr. 4, '92. Also common in other sections of the State.

190. Dakruma coccidivora. Common, feeding on undetermined Lecanium sp. near Romney, May 7, '94. Adults reàred from larvae.

Order heMIPTERA : Family ANTHOCORIDAE.

191. Anthocoris sp. Frequently found attacking adult Scolytids. inserting its beak through the suture of the elytra decliv- 
ity. Found attracking Tomicus, Pityophthorus and Gnathotrichus,

Order hemirtera : Family cercopidae.

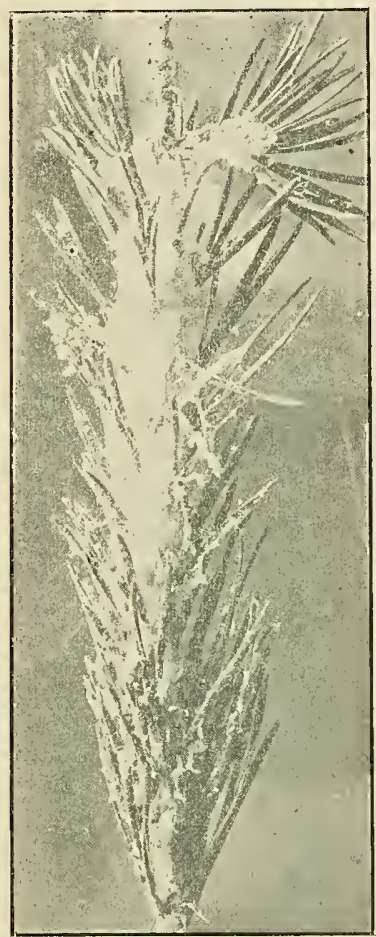

Fig. XCIX.-Rhizocoscus sp. on black spruce.

192. Aphrophora parallela (?) (Spittle insect.) Nymphs very common on pitch pine, near Bruceton Mills, June 22, '97. This or' other species common in pine, spruce, hemlock and balsom fir. Pocahontas, Greenbrier and Randolph counties, July,'93. Comnon on black spruce near Davis, July 11, '91. On yellow and scrub pine, Kanawha Station, May 20,'92.

Order hemptera : Family apHidae.

193. Chermes abietes Linn. The spruce gall louse. Common on native and cultivated spruce. Observed in the southern, middie and northern sections of the spruce area on black spruce, and at Morgantown on Norway spruce.

Order hemiptera : Family cocciDAE.

194, Chionaspis pinitoliza

What was evidently this species was very common on white pine at Nuzums in 1891, causing the foliage to turn yellow and the tree subsequently died.

195. Lecanium sp. (?) Very common on a small scrub pine near Romney May 7, '94.

196. Rhizococcus sp.(?). Observed frequently on pitch, scrub and white pine and on spruce in different sections of the State. Fig. XUIX. Common on small spruce near Cranesville, June $23,97$. 
Order neuroptera : Family termitidae.

197. Termes Alavipes Kallor. Common in old pine logs and stumps. Often injurious to wood work in buildings.

The above list includes 134 species of insects taken from the line, of which 9 may be classed as destructive, 61 as injurious, 42 beneficial and 22 neutral or accidental.

Eighty-four species were taken from the spruce, including 5 destructive, 24 injurious, 37 beneficial and 21 neutral. Some of the species infest both pine and spruce.

The list also includes 24 species of Hymenoptera which were determined by Mr. Ashmead, as new to science. 8 species of Scolytids were found which are believed to be undescribed, and one new fungus disease of the bark beetle was described by Prof. Peck.

There are doubtless many more species of insects which infest the pine and spruce of West Virginia, but this list includes only those which have been observed by the author. 
Owing to technicalities regarding the funds appropriated for printing the bulletins of the station, the printing of this report was all done while the author was conducting investigations for the U. S. Department of Agriculture in the forests of the Northwest; hence it was nut pussible for him to see the proof.

\section{ERRATA.}

Page 197, line 13 from the top for "botonist" read botanist.

" 206, explanation of Fig. 4, for "excelsia," read excelsa.

" $212, \quad$ " "Figs. 8 and 9 , for "Cannan," read Canaan.

" 217 " " Fig. 13, " " "

"240, line 9 from top, for "sawen" read sawed.

" 258, line 13 from bottom for "coelatus," read caelatus.

" 258, foot-note, for "Derdnoctonus," read Dendroctonus.

" 272, explanation of Fig. 33, for "Pin," read Pine.

" 293, line 17 from bottom, for "entomoligist," read entomologist.

" 296 , line 11 from top for "I," read In.

" 305, explanation of Fig. 36, for "pinus," read Pinus.

" $30 \%$, line 1 from bottom for "Bavera" read Baveria.

"309, iines 12 and 13 from top, for "Loraine," read Lorraine.

" 311 , line 2 from bottom, for "pinipeda," read piniperda.

" 315 , line 4 from bottom, for "Hillgard," read Hilgard.

" 40: Explanation of Fig. 70, for "delopment" read development.

" 419, just preceeding line 9 from bottom insert the heading "PREDACEOUS ENEMIES."

" 425 line 2 from top for "pinf" read pine.

" 433, line 11 from bottom for "Lasconotus" read Lacconotus. 


\section{INDEX.}

\section{A}

Abatement of trouble at close of 1892, No, 338.

Abies excelsa, 206, 308.

Acanthocinus obsoletus, 439 .

Acknowledgements, 198.

Agrilus bilineatus, 255, 43\%.

Ambrosia, or timber beetles, 256 .

America, Return to, 316.

American bark beetle destroyer, 262 .

Anthocoris sp., 451 .

Aphrophora parallela, 452.

Area invaded by destructive bark beetle, 368 .

Arhopalus fulminans, $343,429$.

Asemum moestum, 345, $426,438$.

Aulacus abdominalis, 429 .

Aulonium tuberculatum. 344, 433.

\section{B}

Baptolinus longiceps, 433.

Bark miners, 244.

Beaty, J. R. 302, 340.

Beneficial elements, 269.

Bennett, Frank. 34\%.

Best, E. C. 302.

Bibliography, 200.

Birds as friends of the spruce, 269.

Bracon mavoritus, 426 .

pectinator, 426.

pissodes, 426.

simplex, 426 .

sp. a, 426 .

Braconid new genus, 42\%.

parasites, 266.

\section{C}

Caenophanes pityophthori, 42\%.

Callidium antennalum, 438.

Camden, Hon. J. N., 228, 300, 302.

Camponotus penusylanicus, 431.

Camaan Valley, 232.

Canifa pallipes, 440 .

Cecidostiba dendroctoni, 428. polygraphi, 346.428 .
Cedius spinosus, 432.

Cephalonomia hyalinipennis, 428 .

Chalcid parasite, 267.

Chalcophora liberta, 436 .

virginiensis, 344,436 .

Chermes abietis, 260.

Chilocorus bivulnerus, 433 .

Chinch bug, 376 .

Chittenden, F. H., 393.

Chionaspis pinifolia, 452.

Chlaenius tricolor, 432 .

Cholera epidemıc, 313.

Cholerus zimmermanni, 432 .

Chrysobothris azurea, 437.

Clerids, 262 . pusilla, 428, 437 .

Clerus dubius, 320. formicarius, $300,304,316,320$ observ's on habits of, 311 . quadriguttatus, 345,437 . quadrisignatus,var. nigripes, 437.

Climatic conditions, $3 \%$.

Clover leaf beetle, 376 .

Colastus unicolor, 435.

Colydium lineola, 284, 433.

Condon Lane Boom \& Lumber Co., 302.

Copturus longulus, 427, 431, 441 .

Corticaria elongata, 435.

Correspondence with German entomologists, 300 .

Correspondence with owners of spruce and pine timber, 297 .

Cosmopolitian spruce bark beetle, $25 \%$.

Cosmophorus hopkinsii, 427. klugii, 427.

Cossonus corticola, 281, 441.

Coxelus guttulatus, 433.

Cremastus n. sp., 246.

Cryphalus piceae, 444.

Crypturgus alutaceus, 448. pusillus, $346,448$.

Cumberland Lumber Co., 302.

Cychrus ridingsii, 431.

Cylindrocola dendroctoni, 374 . 
Cymatodera inornata, 437.

D

Dakruma coccidivora, $426, \mathbf{4 5 1}$.

Davis, Hon. H. G., 228.

Decatomidea polygraphi, 429 .

Dendroctonus, genus of, 392 .

Dendroctonus frontalis, 245, 283, $28+, 286,289,290,291,293,294$, $296,298,301,320,327,344,346$, $350,394,426,429,448$.

Bibliography, 395 .

Characteristic features of injury of, 413 .

Cause of death of, 470 .

Description of, 394 , eggs, larva and pupa, 396.

Distribution of, $40 \%$. enemies, Predaceous and parasitic of, 378 .

Friendly elements,411.

Galleries of. $39 \%$.

Brood exits, 400 .

Hibernating, 400.

Egg cavaties, 400.

Larval mines, 400.

Main Entrance, $39 \%$.

Nuptial chambers,399.

Preliminary, $39 \%$.

Primary, secondary and brood, 399 .

Pupa cases, 400.

Habits of, 403.

Habit of flight of, 406 .

Host plants of, $40 \%$.

Life history, 401.

Natural enemies, 408.

Birds, 410 ,

Diseases, climatic conditions, etc., 411.

Parasitic, 408.

Predaceous, 409.

Robbers, 410.

Remedies and preven-

tatives, 41z.

Dendroctonus rufipennis, 349, 393.

simplex, 394, 434, 447 .

terebrans, 284,294 ,

$296,333,342,344$,

$347,392,415.447$.

Character of injury of, 419.

Description, 415.
D. terebrans-Continued.

Adult, 392, 515,

Egg, 515.

Larva. 515.

Pupa, 416.

Habits and life history of, 416 .

Kinds of trees attacked by, 420 .

Natural enemies, 420.

Destructive bark beetles, 392 .

Destructive pine bark beetle, (Dendroctonus frontalis) $23 \%, 239$, 245.

All examples of, dead, 431 .

Destructive spruce bark beetles, (Polygraphus rufipennis), 235, 246.

Abundance of, and its economic relations to the spruce, 250 .

Distribution, 249.

Imported enemy of, 251,

Method of combatting and preventing future loss by, 250 .

Natural enemies of, 251.

Drevious knowledge of habits of, 249.

Trees infested by, 249.

Destructive scolytids and their imported enemy, 353.

Destructive sapwood borers, 242. sprace wood miner, 259.

Destruction of timber by snow and wind, 309.

Destruction. Total, of pine and spruce threatened, 296.

Dicerca punctulata, 436 .

Diomorus zabriskii, 429.

Diplosis pini-rigidae, 451.

Diseases, of insect enemies of the spruce, 268.

Dobbins, Judge, 230.

Don, Dr. C. A., 301.

Dromius quadricollis, 432 .

Dryocoetes autographus, 252, 316, $346,42 \%, 433,445$.

$$
\text { granicollis, } 251,346,445 .
$$

Dryophanta gemmula, 426.

\section{$\mathbf{E}$}

Elaterid larva, 436. 
Elkins, Hon. S. B., $22 \mathrm{~S}$.

Ellychnia corrusca, 437.

Endomychus biguttatus, 433.

Entumological Soc. Wash. 317.

Attended meeting of, 317 .

Remarks at, 318.

Eichhoff, W., 284, 296,300, 303, 305, 315 .

Eichhoff's five-toothed pine bark beetle, 353 .

Epuraea avara, 435. truncatella. 435.

European bark beetle destroyer, 239. distribution of. 239.

Eupelmus cleri $343,429$.

Euphorinae, $42 \%$.

Eurytoma cleri, 345,429 tomici, 429 . sp. f. 429 .

Eustrophus tomentosus, 440 .

Expenses of importing clerids, 330 .

\section{F}

Fisher, Mr. Adam. 255.

Fisk, Mr. W. F. 393.

Five-toothed bark beetle, Eichhoff's. 253.

Flat headed spruce bark miner, $25 t$.

\section{G}

Gelechia pinifoliella, 451.

Glyptoscelis pubescens, 440 .

Gnathotrichus materiarius, 344,346 , $34 \%, 434,442$.

Grant County, Conditions in, spruce. 349.

Graphisurus pusillus, 439.

Greenbrier county, Conditions in, scrub pine, 344 .

\section{H}

Hambric, Mr., 233.

Helcon occidentalis, 427.

Henderson, Robt. R., 300, 302.

Heydenia unica. 345, 429.

Hilgard, Dr. E. W.. 315.

Himatium conicum, 441. errans, 441.

Hister cylindricus, 265, 343, 344, 434.

lecontei, 434 .

parallelus, 434 .

Homalota pontomaloto, 265.

Hutton, Col. E., 233.

Hylastes cavernosus, 345, 347, 356. gracilis, 347 .
Hylastes porculus, 448 .

tenuis, $345,449$.

Hylesinus polygraphus, $42 \%$.

Hylobius pales, 441 .

Hylurgops glabratus, 294, 242. 34\%, 449.

pinifex, 449 .

Hypophloens parallalus, 266, 440. tenuis, 440 .

thoracicus, 440.

Hypothenemus n. sp. h. 444.

n. sp. i, 444.

Icerya, 319.

Ichneumonid parasites, 266 .

Imported insects, Methods of locating colonies of, 326 . distribution of, in 1893,326 .

Importation of natural enemies of bark beetles considered, 295.

Insects associated with the pine trouble, 379.

Insect diseases, $3 \% 4$.

friends of the spruce, 262.

enemies of the spruce in $\pi$. Ta., 244.

Introductory, 198.

Investigations near Hagenau, 305. continued near Hagenau, 30 s. in Saxony, 306.

in Tosges Mt's, 309.

Invasion, Two remarkable features, 369.

Ips confluentus; 435.

fasciatus, 266,435 .

sanguinolentus, 343 .

vittatus, 343,435 .

K

Kanawha county, Conditions in, scrub pine, 343 .

Kirkpatrick, Mr., 359.

$\mathbf{L}$

Lacconotus referendarius, 433.

Laemophloeus testaceus, 434.

Lecanium sp., 452.

Le Conte's spruce bark beetle, 251.

Legislation for insect control, 323.

Leptinotar'sa decimlineata, 320 .

Letter of instruction, 302.

to Legislator's, 325.

to lumber companies, 301, $321,325$.

Lintner, Dr. J. A , 393. 
Lochites, sp. a., 429.

sp. c and d, 428.

sp b and e. 429 .

Lophoderus politanus, 4501.

Lophyrus pini-rigidae, 425.

Lucidota atra, 437.

Lumber Company, Blacli Trater. 233.

St. Lawrence, 233.

M

Maxwell, Mr. Hu. 260.

Mayfield Hill Grove, conditions in, 3 อั8.

Observations in, 35\%.

Medeterus nigripes, 268, 450 .

Melanotes communis, 436.

Melanophilia fulvoguttata, 429.

Millspaugh, Dr. C. F,, 374.

Mission to Europe, account of, 303 ,

Monaghan, E. A., 302.

Nonarthrum fasciatum, 442. mali, 347, 442 .

Monohammus confusor, 439, scutellatus, 439 .

titillator, 439.

Money contributed by owners of timber, 302.

Monongalia Co., conditions in, scrub, pitch and yellow pine, 339 .

observations in. Tibbs Run forest, 3อ̃อั.

Mountain pastures, 213.

Myelophilus minor, 31I.

pıniperda, 311.

Myers, Dr. Jno. A., 303, 314, 323.

\section{$\mathbf{S}$}

Natural enemies, further observations on, 336.

Nemosoma cylindricum, 344, 435.

Nitulid beetles and their larvae, 265.

Notes in 1893, Further, 352.

Number of clerids collected, imported and distributed, 330 .

\section{0}

Observations after return from Europe, $33 \%$.

during summer and fall, $1892,232$.

during spring and summer, 1893,339 .

in spring, 1893, conclusions
Observations-Continued. from, 350 .

in $1895-6,364$.

on habits of C. formicarius, 311.

Olibrus bicolor, 433 .

Olophrum obtectum, 433.

Omalium pusillum, 433.

\section{$\mathbf{P}$}

Pachyceras, 430.

Packard, S. A., 393.

Parasitic insects, 266.

Paromalus bistriatus, 265, 434. difficilis, 434.

Parsons, Capt., 233, 23\%.

Paururus (Urocerus) edwardsii, $266,425,426$.

pinicolus, 425 .

cyaneus, 426.

Peck, Prof., 374, 393.

Perpetuation of forests, Relation of entomological research to, 229 .

Philothermus glabricuius, 433.

Phyllobaenus dislocatus, 437.

Phymaphora pulchella, 433.

Phymatodes dimidiatus, 346, 438.

Picea mariana, 293.

Pieris brassicae, 320 .

Phytonomus punctatus, $3 \pi 6$.

Piltz oberfoster, 309.

Pimplid, 426.

Pine of West Virginia, 271.

Commercial products of, 276 .

Comparative value of, to that of other kinds of forest trees, 281.

Conditions of, $2 \pi 6$.

Influences causing destruction of, 278.

Investigations, $2 \% 1$.

Investigation of, History of, to determine cause of trouble, 282.

Cause discovered, 289.

Character, discovered, 287.

Correspondence, 284.

First observations, 283.

Further investigations, 292.

Peculiar character of common-trouble, 289 .

Special investigation commenced, $28 \%$.

Trees dying from a natural cause, 288.

Trees dying from a disease, 288.

Loblolly, 274.

Original distribution of, 276. 
Pine of West Virginia-Continued.

pitch or black, 272, 293.

Present distribution and conditions of, 2\%\%.

Principal enemies of, 291.

Rate of consumption to that uf natural increase of, 280.

Red or Canadian, 274.

Relation in amount and value to that of other kinds of forest trees, 280 .

Scrub or Yirginia, 273, 293.

Table mountain, 273, 293.

White, 2\%1.

Yellow. $2 \pi 1$.

Pissodes strobi, 259, 284, 345, 427, 429. 441.

Pinus echinata, 2น1, 293.

inops, 293.

pungens, 273, 293.

resinosus, $2 \pi 4$.

rigida, 272,293 .

strobus 271,293 ,

sylvestris, 303.

Virginiäna 273, 293.

Pityogenes curvidens, 310, 311.

plagiatus, $342,42 \%, 429,447$.

sparsus, 446.

Pityophthorus cariniceps, 42\%, 443. confinis, $284,344,443$.

cribripennis, 437 .

lautus 344.

puberulus, 443.

pulchellus, 442.

pulicarius, 442 .

pullus. 344,442 .

tuberculatus, 443 .

$\mathrm{n}, \mathrm{sp} .443$.

n. sp. e. 143.

n. sp. 1,444 .

n. sp. n., 444

n. sp. q., 413 ,

n. sp. r. 444 .

n. sp. s. 443

Placusa sp , 432.

Platynus angustatus, 432.

sinuatus, 432 .

Plegaderus transversus, 434 .

Podapion gallicola, 441.

Polygraphus polygraphus. 427.

rufipennis, $235,246,296,299$,

$319,349,346,427,428,429,447$.

Power, J R.. 341

Prenaceous beetles and their larvae, 262.

Primary object of importation of clerids prevented, 328.

Prionus laticollis, 438
Pterostichus odoxus, 432. honestus, 431.

Pytho americanus, 441. niger, 440.

\section{Q}

Quedius peregrinus, 432.

\section{$\mathbf{R}$}

Raleigh county, conditions in, white pine, 340 .

observations in white pine, 356 .

Randolph county, Conditions in, spruce, 348 .

Remedies considered, 294, 319.

Retinia comstockiana, 451. frustrana, 451 .

Riley, Dr. C. T. $31 \%$.

Rhagium lineatum, 439.

Rhizococcus sp., 452.

Rhizophagus cylindricus, 435. dimiảiatus, 435 .

Rhysipolis biformis, 428.

Rhyssa albomaculata, 266, 426.

Rhyssalus pityophthori, 428

Roptrocerus ecceptogastri, 429, 430. xylophagorum, 429, 430 .

Round headed spruce miners, 255, wood miners. 258.

Ruffner, Mr. 233.

\section{S}

Say's pine bark beetle. 25.3 .

Schaufuss. Director Camillo, 300 , $301,30 \%, 315$

Scleroderma macrogaster, 431.

Scolytids, 379 .

Birds destructive to, $38 \%$.

Distribution of species, 385

grouped according to habits, 380

Insects and other friends of, 387

Habits of 376 .

Knowledge of habits of, may prevent ravages, 391 .

Mines or galleries of 380 .

Brood exits, 284 .

Brood galleries, 383.

Egg cavities, 383.

Food burrows, 384.

Hibernating burrows, 384, Larva mines, 383.

Larvae and pupae cham. bers. 383 . 
Scolytids-Continued.

Main entrance. 381.

Nuptial chambers, 381.

Preliminary burrows, 384 .

Primary galleries 383.

Pupa cases, 384.

Secondary galleries, 383

Side entrances and exits. $3 s 1$.

Natural enemies of, 386 .

Parasitic diseases of, 387

Parasitic insect enemies, of, 386 .

Predaceous insect enemies of, 386

Preferance of, for coniferous trees, $3 \% 6$.

Preventives and remedies 389.

Robbers of, 387.

Unfavorable climatic and other conditions for $38 \%$

Science, extracts frum article in. 293

Scolytus rugulosus, 295, 296.

Scrub Pine, 293

Serropalpus barbatus, 440 .

Shaw, Mr. $34 \%$.

Siagonium americanum. $43: 3$

Sirex (Ưrocerus) cressoni, 425.

Sparhius abdominalis, $42 \%$.

brevicaudus, $42 \%$.

brachyurus, $42 \%$.

canadensis, 427

claripennis, 428 .

pallidus, $4: 28$

simillimus, +28 .

tomici, 428 .

Spintherus sp 428

Spruce in West Virginia. 203

Agricultural influences of, 225.

Causes of first trouble of, 23 อ.

Cause of second trouble of, $23 \%$,

Circular letter regarding, 238

Commercial influences in their relation to the future of the area of, 223 .

Common and technical names of, 204.

Description of, $20 \%$

Distribution of: 208.

Disturbing influences of 211 , 230.

End of the trouble to, 239.
Spruce in West Virginia-Contin'd. History and progress of $d y$ ing, 232

Investigations of, 204.

Original area of, greatly reduced, 21i.

Present condition as to insect enemies of. 242 .

Present conditions in area of 26 .

Probable future of the area as indicated by present conditions of, 221 .

Rapid decay of dead timber in one section of the area of, 239.

Report of investization to determine the cause of the unhealthy condition of, between 1880 and 1893,231 .

Spruce gall louse, 260 .

Norway, in Morgantown, 350 . and pine in Md. and D. C. dying. 336

timber beetle. 256 .

Staphylinid or rove beetle and their larvae. 264 .

St. Lawrence Boom \& Lumber Co., 302.

Stored for the winter, imported clerids, 322

Strahmever, Mr H 309.

Strayer, Mr. J, S. 284. 286.

Strassburg. Returned to, 305, 30\%.

Swarms of bark beetle, 246, 266.

\section{$\mathbf{T}$}

Table mountain pine, 273293.

Tachina sp. 449 .

Tachinid parasites, $\mathbf{2 6 5}$.

Tachys nanus. 431.

Taylor, Andy 316 .

Tenebrionid beetles 266 .

Tenebrio castaenus. 440 .

Termes Havipes. 453.

Tetrastichus thanasimi, 430 .

Tetropium cinnamopterum, 259, $42 \%, 438$.

Thalessa uortoni. 266426.

Thanasimus dubius $262,334,343$, 344.437 .

trifasciatus, $343.429,437$.

Timber or a mbrosia beetles. 56 .

Tomicobla tibialis. n. g., n. sp. 430 .

Tomicus, genus of, 421 . avulsus, $344,422,445$. 
Tomicus-Continued.

caelatus $258,342,423,446$,

cacographus, 252, 284. 314, $347.422,427,428.445$

calligraphus 284, 294, 342, 422,445

cembrae, 316.

pini $23 \quad 342344422,445$.

Trichodes simulator, 345 .

Trigonoderus sp 428 .

Trogosita virescens, 435.

Trouble, alarming character of, 335

Cause of. 33), 367 .

End of, 367 .

Extent and distribution of, 297.

Further, prevented, 368.

over, A serious, 363.

threatened by swarms of bark beetles, 366 .

Tucker county, conditions in, spruce 358.

pitch and white pine, 348 .

Tunis. MIr. E. L, 300. 302.

$\mathbf{U}$

Urocerus abdominalis, 425.

cyaneus. 425.

pinicolus, 425.

sp. a, 426.

sp. d. 425.

V

Valgus canaliculatus, 438 .

Vedalis cardinalis, 319.

W

Weed. C. M. 393.

West Virginia \& Pittsburg Railroad, 302.

White pine, 293.

White pine weevil, 259 .

White, Dr I C., 222.

Williams River, Conditions on, in spruce, 346.

Woodpeckers enemy of heartwood borers, 242.

Wood miners, 255.

\section{$\mathbf{X}$}

Xantholinus cephalus, 432. emmesus, $43 \%$.

Xestobium squalidum, 438.

Xyleborus pubescens, 445 . xylographus, $258,347$.

Xyletinus peltatus, 431,438 .

Xylita laevigata, 440

Xyloterus bivittatus 349, 444. lineatus $256,310,444,446$. politus, $44^{4}$. scabricollis, 444.

\section{Y}

Yellow pine, 293.

\section{Z}

Zapachia copturi, 431 . 
